\title{
Effects of Fiscal Stimulus in Structural Models
}

Günter Coenen, Christopher Erceg, Charles Freedman, Davide Furceri, Michael Kumhof, René Lalonde, Douglas Laxton, Jesper Lindé, Annabelle Mourougane, Dirk Muir, Susanna Mursula, Carlos de Resende, John Roberts, Werner Roeger, Stephen Snudden, Mathias Trabandt, and Jan in 't Veld 


\title{
IMF Working Paper
}

\author{
Research Department
}

\section{Effects of Fiscal Stimulus in Structural Models}

\author{
Prepared by Günter Coenen, Christopher Erceg, Charles Freedman, Davide Furceri, \\ Michael Kumhof, René Lalonde, Douglas Laxton, Jesper Lindé, Annabelle Mourougane, \\ Dirk Muir, Susanna Mursula, Carlos de Resende, John Roberts, Werner Roeger, \\ Stephen Snudden, Mathias Trabandt and Jan in 't Veld ${ }^{1}$
}

Authorized for distribution by

March 2010

\begin{abstract}
This Working Paper should not be reported as representing the views of the IMF. The views expressed in this Working Paper are those of the author(s) and do not necessarily represent those of the institutions with which the authors are affiliated. Working Papers describe research in progress by the author(s) and are published to elicit comments and to further debate.

The question of whether temporary fiscal stimulus can effectively stimulate aggregate demand has become the subject of a lively debate that is critical for future policy decisions. Empirical studies can provide some guidance, but their estimates are very dispersed, and they have difficulties identifying key issues including the interaction between monetary and fiscal policies, the distinction between different fiscal instruments, and the distinction between automatic stabilizers and discretionary stimulus. Structural models can address these issues, and they can provide valuable additional identifying information. Their main weakness is incomplete consensus on structural features and calibration. To assess the importance of this problem, this paper subjects seven different structural models, all used heavily by policymaking institutions, to fiscal stimulus shocks using seven different fiscal instruments. The most important result is that there is considerable agreement across models on both the absolute and relative sizes of different types of fiscal multipliers. Three other conclusions stand out. First, the size of many multipliers is large, particularly for spending and targeted transfers. Second, fiscal policy is most effective if it has some persistence and if monetary policy accommodates it. Third, permanent fiscal stimulus has significantly lower initial multipliers, and reduces output in the long run.
\end{abstract}

JEL Classification Numbers: $\quad$ E62; F41;F42; H30; H63

Keywords: Fiscal Policy, Fiscal Stimulus, Fiscal Multipliers, Government Deficits

Author's E-Mail Address: $\quad$ dmuir@imf.org

\footnotetext{
${ }^{1}$ The authors wish to thank David Romer, Olivier Blanchard, and Steve Symansky for their invaluable comments on this work. This paper should not be reported as representing the views of the IMF, its Executive Board or any member government. The views expressed are those of the authors and do not necessarily reflect the views of the IMF, IMF policy, or any other institution mentioned herein or with which the authors are affiliated.
} 


\section{Contents}

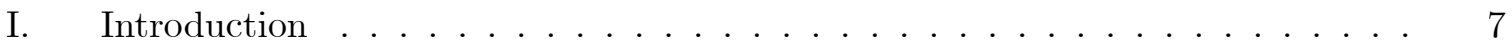

II. Fiscal Multipliers: Empirical and Model-Based Evidence . . . . . . . . . . . 8

III. Multipliers, Instruments, and Models _ . . . . . . . . . . . . . . . . . . 10

A. Definition of Fiscal Multipliers . . . . . . . . . . . . . . . 10

B. The Seven Fiscal Instruments . . . . . . . . . . . . . . . . . 11

C. The Seven Structural Models . . . . . . . . . . . . . . . . . . . . . 12

IV. Fiscal Multipliers for Temporary Stimulus . . . . . . . . . . . . . . . . . . . . 12

A. Introduction to Simulation Results . . . . . . . . . . . . . . . . 12

B. Government Investment - Detailed Discussion . . . . . . . . . . . . . 13

C. The Role of Monetary Accommodation . . . . . . . . . . . . . . . . 15

D. The Persistence of Fiscal Stimulus . . . . . . . . . . . . . . . . . 16

E. Government Spending versus Taxes and Transfers . . . . . . . . . . 17

F. Different Taxes and Transfers . . . . . . . . . . . . . . . . . . . . 17

G. General Transfers versus Targeted Transfers . . . . . . . . . . . . . 18

H. United States versus Europe . . . . . . . . . . . . . . . . . . 18

V. Permanently Higher Deficits and Debt . . . . . . . . . . . . . . . . 20

A. Permanently Higher Deficits and Short-Run Multipliers . . . . . . . . . . 20

B. Permanently Higher Deficits and Long-Run Crowding Out . . . . . . . . 21

VI. Effects of G-20 Fiscal Packages . . . . . . . . . . . . . . . . . . 22

VII. Concluding Remarks . . . . . . . . . . . . . . . . . . . . . 23

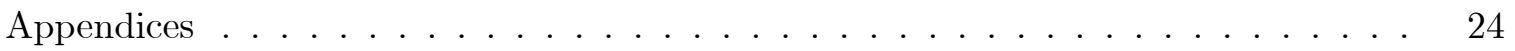

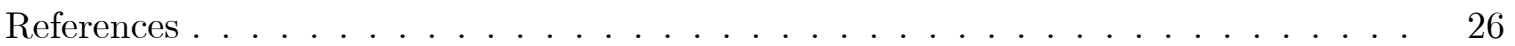

Figures

1. United States: Effect of 1 Year of Fiscal Stimulus on Real GDP (Instrument: Government Investment) . . . . . . . . . . . . . . . . . .

2. United States: Effect of 1 Year of Fiscal Stimulus on Inflation and the Real Interest Rate (Instrument: Government Investment) . . . . . . . . . . . . . .

3. United States: Effect of 1 Year of Fiscal Stimulus on Consumption and Investment (Instrument: Government Investment) . . . . . . . . . . . . . . 31

4. United States: Effect of 1 Year of Fiscal Stimulus on Real GDP (Instrument: Government Consumption) . . . . . . . . . . . . . . . . . 32

5. United States: Effect of 1 Year of Fiscal Stimulus on Inflation and the Real Interest Rate (Instrument: Government Consumption) . . . . . . . . . . . . .

6. United States: Effect of 1 Year of Fiscal Stimulus on Consumption and Investment (Instrument: Government Consumption) . . . . . . . . . . . . .

7. United States: Effect of 1 Year of Fiscal Stimulus on Real GDP (Instrument: General Transfers $\ldots \ldots \ldots \ldots \ldots \ldots$ 
8. United States: Effect of 1 Year of Fiscal Stimulus on Inflation and the Real Interest Rate (Instrument: General Transfers) . . . . . . . . . . . . . .

9. United States: Effect of 1 Year of Fiscal Stimulus on Consumption and Investment (Instrument: General Transfers) . . . . . . . . . . . . . . . . .

10. United States: Effect of 1 Year of Fiscal Stimulus on Real GDP (Instrument:

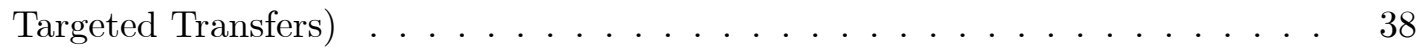

11. United States: Effect of 1 Year of Fiscal Stimulus on Inflation and the Real Interest Rate (Instrument: Targeted Transfers) . . . . . . . . . . . . . . .

12. United States: Effect of 1 Year of Fiscal Stimulus on Consumption and Investment (Instrument: Targeted Transfers) . . . . . . . . . . . . . . . .

13. United States: Effect of 1 Year of Fiscal Stimulus on Real GDP (Instrument:

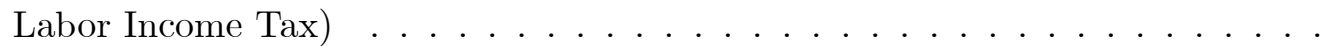

14. United States: Effect of 1 Year of Fiscal Stimulus on Inflation and the Real Interest Rate (Instrument: Labor Income Tax) . . . . . . . . . . . . . . . .

15. United States: Effect of 1 Year of Fiscal Stimulus on Consumption and Investment (Instrument: Labor Income Tax) . . . . . . . . . . . . . . . . .

16. United States: Effect of 1 Year of Fiscal Stimulus on Real GDP (Instrument: Consumption Tax $\ldots \ldots \ldots \ldots \ldots$

17. United States: Effect of 1 Year of Fiscal Stimulus on Inflation and the Real Interest Rate (Instrument: Consumption Tax) . . . . . . . . . . . . .

18. United States: Effect of 1 Year of Fiscal Stimulus on Consumption and Investment (Instrument: Consumption Tax) . . . . . . . . . . . . . . . 46

19. United States: Effect of 1 Year of Fiscal Stimulus on Real GDP (Instrument: Corporate Income Tax $\ldots \ldots$. . . . . . . . . . . . . . . 47

20. United States: Effect of 1 Year of Fiscal Stimulus on Inflation and the Real Interest Rate (Instrument: Corporate Income Tax) . . . . . . . . . . . . . . . .

21. United States: Effect of 1 Year of Fiscal Stimulus on Consumption and Investment (Instrument: Corporate Income Tax) . . . . . . . . . . . . . . . .

22. United States: Effect of 2 Years of Fiscal Stimulus on Real GDP (Instrument: Government Investment) _ . . . . . . . . . . . . . . 50

23. United States: Effect of 2 Years of Fiscal Stimulus on Inflation and the Real Interest Rate (Instrument: Government Investment) . . . . . . . . . . . .

24. United States: Effect of 2 Years of Fiscal Stimulus on Consumption and Investment (Instrument: Government Investment) . . . . . . . . . . . . . . .

25. United States: Effect of 2 Years of Fiscal Stimulus on Real GDP (Instrument: Government Consumption) . . . . . . . . . . . . . . . .

26. United States: Effect of 2 Years of Fiscal Stimulus on Inflation and the Real Interest Rate (Instrument: Government Consumption) . . . . . . . . . . . .

27. United States: Effect of 2 Years of Fiscal Stimulus on Consumption and Investment (Instrument: Government Consumption) . . . . . . . . . . . . . . .

28. United States: Effect of 2 Years of Fiscal Stimulus on Real GDP (Instrument: General Transfers $\ldots \ldots \ldots \ldots \ldots$. . . . . . . . . . . . . . . . . . .

29. United States: Effect of 2 Years of Fiscal Stimulus on Inflation and the Real Interest Rate (Instrument: General Transfers) . . . . . . . . . . . . .

30. United States: Effect of 2 Years of Fiscal Stimulus on Consumption and Investment (Instrument: General Transfers) . . . . . . . . . . . . . . . 58

31. United States: Effect of 2 Years of Fiscal Stimulus on Real GDP (Instrument: Targeted Transfers $) \ldots \ldots \ldots \ldots \ldots$ 
32. United States: Effect of 2 Years of Fiscal Stimulus on Inflation and the Real Interest Rate (Instrument: Targeted Transfers) . . . . . . . . . . . . . . . . .

33. United States: Effect of 2 Years of Fiscal Stimulus on Consumption and Investment (Instrument: Targeted Transfers) . . . . . . . . . . . . . . . .

34. United States: Effect of 2 Years of Fiscal Stimulus on Real GDP (Instrument:

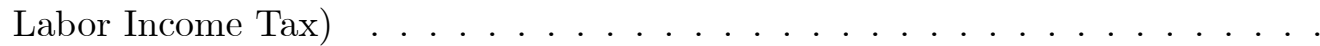

35. United States: Effect of 2 Years of Fiscal Stimulus on Inflation and the Real Interest Rate (Instrument: Labor Income Tax) . . . . . . . . . . . . . . .

36. United States: Effect of 2 Years of Fiscal Stimulus on Consumption and Investment (Instrument: Labor Income Tax) . . . . . . . . . . . . . . . . . .

37. United States: Effect of 2 Years of Fiscal Stimulus on Real GDP (Instrument: Consumption Tax $\ldots \ldots \ldots \ldots \ldots$

38. United States: Effect of 2 Years of Fiscal Stimulus on Inflation and the Real Interest Rate (Instrument: Consumption Tax) . . . . . . . . . . . . . . .

39. United States: Effect of 2 Years of Fiscal Stimulus on Consumption and Investment (Instrument: Consumption Tax) . . . . . . . . . . . . . . .

40. United States: Effect of 2 Years of Fiscal Stimulus on Real GDP (Instrument: Corporate Income Tax $\ldots \ldots \ldots$. . . . . . . . . . . . . 68

41. United States: Effect of 2 Years of Fiscal Stimulus on Inflation and the Real Interest Rate (Instrument: Corporate Income Tax) . . . . . . . . . . . . .

42. United States: Effect of 2 Years of Fiscal Stimulus on Consumption and Investment (Instrument: Corporate Income Tax) . . . . . . . . . . . . . . . .

43. Euro Area / European Union: Effect of 1 Year of Fiscal Stimulus on Real GDP (Instrument: Government Investment) . . . . . . . . . . . . . . . .

44. Euro Area / European Union: Effect of 1 Year of Fiscal Stimulus on Inflation and the Real Interest Rate (Instrument: Government Investment) . . . . . . .

45. Euro Area / European Union: Effect of 1 Year of Fiscal Stimulus on Consumption and Investment (Instrument: Government Investment) . . . . . . . . . . .

46. Euro Area / European Union: Effect of 1 Year of Fiscal Stimulus on Real GDP (Instrument: Government Consumption) . . . . . . . . . . . . . .

47. Euro Area / European Union: Effect of 1 Year of Fiscal Stimulus on Inflation and the Real Interest Rate (Instrument: Government Consumption) . . . . . .

48. Euro Area / European Union: Effect of 1 Year of Fiscal Stimulus on Consumption and Investment (Instrument: Government Consumption) . . . . . . . . . .

49. Euro Area / European Union: Effect of 1 Year of Fiscal Stimulus on Real GDP (Instrument: General Transfers) . . . . . . . . . . . . . . . . . .

50. Euro Area / European Union: Effect of 1 Year of Fiscal Stimulus on Inflation and the Real Interest Rate (Instrument: General Transfers) . . . . . . . . . . .

51. Euro Area / European Union: Effect of 1 Year of Fiscal Stimulus on Consumption and Investment (Instrument: General Transfers) . . . . . . . . . . . . .

52. Euro Area / European Union: Effect of 1 Year of Fiscal Stimulus on Real GDP (Instrument: Targeted Transfers) . . . . . . . . . . . . . . . . . .

53. Euro Area / European Union: Effect of 1 Year of Fiscal Stimulus on Inflation and the Real Interest Rate (Instrument: Targeted Transfers) . . . . . . . . . .

54. Euro Area / European Union: Effect of 1 Year of Fiscal Stimulus on Consumption and Investment (Instrument: Targeted Transfers) . . . . . . . . . . . . .

55. Euro Area / European Union: Effect of 1 Year of Fiscal Stimulus on Real GDP

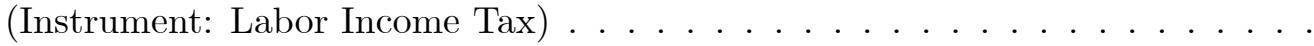


56. Euro Area / European Union: Effect of 1 Year of Fiscal Stimulus on Inflation and the Real Interest Rate (Instrument: Labor Income Tax) . . . . . . . . . .

57. Euro Area / European Union: Effect of 1 Year of Fiscal Stimulus on Consumption and Investment (Instrument: Labor Income Tax) . . . . . . . . . . .

58. Euro Area / European Union: Effect of 1 Year of Fiscal Stimulus on Real GDP (Instrument: Consumption Tax) . . . . . . . . . . . . . . .

59. Euro Area / European Union: Effect of 1 Year of Fiscal Stimulus on Inflation and the Real Interest Rate (Instrument: Consumption Tax) . . . . . . . . . . .

60. Euro Area / European Union: Effect of 1 Year of Fiscal Stimulus on Consumption and Investment (Instrument: Consumption Tax) . . . . . . . . . .

61. Euro Area / European Union: Effect of 1 Year of Fiscal Stimulus on Real GDP (Instrument: Corporate Income Tax) . . . . . . . . . . . . . . . . .

62. Euro Area / European Union: Effect of 1 Year of Fiscal Stimulus on Inflation and the Real Interest Rate (Instrument: Corporate Income Tax) . . . . . . . .

63. Euro Area / European Union: Effect of 1 Year of Fiscal Stimulus on Consumption and Investment (Instrument: Corporate Income Tax) . . . . . . . . . . .

64. Euro Area / European Union: Effect of 2 Years of Fiscal Stimulus on Real GDP (Instrument: Government Investment) . . . . . . . . . . . . . . . . .

65. Euro Area / European Union: Effect of 2 Years of Fiscal Stimulus on Inflation and the Real Interest Rate (Instrument: Government Investment) . . . . . . .

66. Euro Area / European Union: Effect of 2 Years of Fiscal Stimulus on Consumption and Investment (Instrument: Government Investment) . . . . . . . . . .

67. Euro Area / European Union: Effect of 2 Years of Fiscal Stimulus on Real GDP (Instrument: Government Consumption) . . . . . . . . . . . . . . .

68. Euro Area / European Union: Effect of 2 Years of Fiscal Stimulus on Inflation and the Real Interest Rate (Instrument: Government Consumption) . . . . . .

69. Euro Area / European Union: Effect of 2 Years of Fiscal Stimulus on Consumption and Investment (Instrument: Government Consumption) . . . . . . . . . .

70. Euro Area / European Union: Effect of 2 Years of Fiscal Stimulus on Real GDP (Instrument: General Transfers) . . . . . . . . . . . . . . . .

71. Euro Area / European Union: Effect of 2 Years of Fiscal Stimulus on Inflation and the Real Interest Rate (Instrument: General Transfers) . . . . . . . . . . .

72. Euro Area / European Union: Effect of 2 Years of Fiscal Stimulus on Consumption and Investment (Instrument: General Transfers) . . . . . . . . . . . . .

73. Euro Area / European Union: Effect of 2 Years of Fiscal Stimulus on Real GDP (Instrument: Targeted Transfers) . . . . . . . . . . . . . . . . .

74. Euro Area / European Union: Effect of 2 Years of Fiscal Stimulus on Inflation and the Real Interest Rate (Instrument: Targeted Transfers) . . . . . . . . . .

75. Euro Area / European Union: Effect of 2 Years of Fiscal Stimulus on Consumption and Investment (Instrument: Targeted Transfers) . . . . . . . . . . . . .

76. Euro Area / European Union: Effect of 2 Years of Fiscal Stimulus on Real GDP

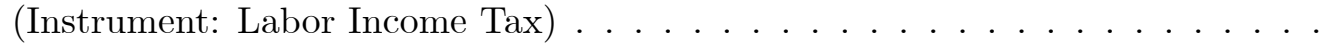

77. Euro Area / European Union: Effect of 2 Years of Fiscal Stimulus on Inflation and the Real Interest Rate (Instrument: Labor Income Tax) . . . . . . . . . .

78. Euro Area / European Union: Effect of 2 Years of Fiscal Stimulus on Consumption and Investment (Instrument: Labor Income Tax) . . . . . . . . . . . . 106

79. Euro Area / European Union: Effect of 2 Years of Fiscal Stimulus on Real GDP (Instrument: Consumption Tax) _ . . . . . . . . . . . . . 107 
80. Euro Area / European Union: Effect of 2 Years of Fiscal Stimulus on Inflation and the Real Interest Rate (Instrument: Consumption Tax) . . . . . . . . . . . 108

81. Euro Area / European Union: Effect of 2 Years of Fiscal Stimulus on Consumption and Investment (Instrument: Consumption Tax) . . . . . . . . . . . . 109

82. Euro Area / European Union: Effect of 2 Years of Fiscal Stimulus on Real GDP (Instrument: Corporate Income Tax) ～. . . . . . . . . . . . . . . 110

83. Euro Area / European Union: Effect of 2 Years of Fiscal Stimulus on Inflation and the Real Interest Rate (Instrument: Corporate Income Tax) . . . . . . . . 111

84. Euro Area / European Union: Effect of 2 Years of Fiscal Stimulus on Consumption and Investment (Instrument: Corporate Income Tax) . . . . . . . . . . .

85. Effect of 2 Years of Fiscal Stimulus on Real GDP (Instrument: Government Investment) . . . . . . . . . . . . . . . . . .

86. Effect of 2 Years of Fiscal Stimulus on Inflation and the Real Interest Rate (Instrument: Government Investment) . . . . . . . . . . . . . . . .

87. Effect of 2 Years of Fiscal Stimulus on Consumption and Investment (Instrument: Government Investment) . . . . . . . . . . . . . . . . . 115

88. Effects of Openness on Short-Run Multipliers . . . . . . . . . . . . . . 116

89. Effects of Nominal Rigidities and Automatic Stabilizers on Short-Run Fiscal Multipliers . . . . . . . . . . . . . . . . 117

90. United States: Effect of 1 Year Fiscal Stimulus and Permanent Change in the Fiscal Instrument on Real GDP (Instrument: Government Consumption) . . . 118

91. Effect of a Permanent Change in Government Consumption in the IMF's GIMF (Shock versus Control) _ . . . . . . . . . . . . . . . . . 119

92. G20 Fiscal Stimulus Packages: Effect on Real GDP . . . . . . . . . . . . . . 120

Tables

1. Key Model Features . . . . . . . . . . . . . . . . . . . . . . .

2. Effects of a Permanent 10 Percentage Point Increase in the U.S. Government Debt to GDP Ratio . . . . . . . . . . . . . . . . . . . . . . . . . 122

3. G20 Fiscal Stimulus Packages . . . . . . . . . . . . . . . . . . 123 


\section{Introduction}

The global economy has over recent years suffered from a number of large negative demand shocks, which were initially driven by sharp declines in house and stock prices and a tightening of financial conditions (see Decressin and Laxton, 2009). The resulting collapse in output and the increase in unemployment also gave rise to a loss of confidence that intensified the downward pressures on the economy.

Governments and central banks responded by introducing measures to deal with liquidity and solvency problems in financial institutions. Central banks reduced interest rates to unprecedented levels to support aggregate demand in the face of an increase in private sector risk premia. They also used nonconventional measures in the form of quantitative easing and qualitative or credit easing to reduce risk premia and to provide liquidity. Despite all of this, credit remained tight and aggregate demand in many countries continued to weaken rapidly. There were negative spillovers from the weakening economies to those that had appeared to be more robust, and increased concern that the global economy might be moving into a period of deep and prolonged recession (IMF, 2009a).

With limited scope for further stimulus through monetary policy, attention turned to fiscal policy. ${ }^{1}$ In this context, questions were raised as to how effective temporary government fiscal policy actions would be in lessening the depth and duration of the slowdown, and what the preferred mix of fiscal policy actions would be. Questions also started to be asked about the long-run sustainability of deteriorating fiscal positions, and about the potential long-run crowding-out effects of the debt accumulation resulting from the fiscal stimulus.

This paper addresses these questions, with the focus very much on the issue of short-run effectiveness, in other words on the size of fiscal multipliers, but with some discussion towards the end concerning long-run issues. The tools we use to address these questions are seven structural models of national economies and of the global economy that have been extensively used and tested over the years in a number of policymaking institutions, including the U.S. Federal Reserve, the European Central Bank, the International Monetary Fund, the European Commission, the OECD and the Bank of Canada.

Comparing the output of these diverse models provides a useful check on the robustness of the predictions produced by state-of-the-art macroeconomic models. We will demonstrate that there is indeed a considerable degree of agreement across theoretical models, particularly if one compares the outcomes with the results of reduced-form empirical work. Furthermore, whenever there are substantial differences, the sources of these differences are fairly straightforward to identify. As we will discuss in Section II, in the empirical literature there has been much disagreement over the effectiveness of different types of temporary fiscal measures in stimulating aggregate demand. Under normal business cycle conditions, the fiscal multipliers in the structural models we consider are typically in the mid-range of the estimates provided by the empirical literature. However, the current situation - in which many central banks are more likely than normally to keep interest rates low for a protracted time period - makes the evidence provided by previous empirical

\footnotetext{
${ }^{1}$ The IMF called for global fiscal stimulus and discussed core principles for the fiscal response to the crisis. See Lipsky (2008), Spilimbergo and others (2008), and Decressin and Laxton (2009). See also IMF (2009b) for a discussion of the state of public finances after the 2008 crisis.
} 
literature less relevant to gauge the effects of fiscal actions, because the estimated models in these studies are designed to assess the effects of fiscal stimulus in a normal situation where central banks will more aggressively act by raising interest rates to keep inflation and inflation expectations contained. In contrast, the structural models we consider are well-equipped to assess the impact of monetary accommodation. We therefore feel that this work adds valuable information that can support the urgent decisions facing policymakers today.

There are several broad conclusions flowing from our analysis. Most importantly, there is no such thing as a simple fiscal multiplier. The size of the response of the economy to temporary discretionary fiscal stimulus depends on a number of factors, including most importantly the type of fiscal instrument used and the extent of monetary accommodation of the higher inflation generated by the stimulus. Temporary expansionary fiscal actions are most effective when the fiscal instrument is spending or well-targeted transfers, and when in addition monetary policy is accommodative. On the other hand, permanent stimulus, that is a permanent increase in deficits, is much more problematic than temporary stimulus. It leads to a long-run contraction in output, but in addition it substantially reduces short-run fiscal multipliers. Finally, the G20 stimulus should have significant effects on global GDP in 2009 and 2010.

The rest of the paper is organized as follows. Section II discusses the relative merits of using empirical evidence versus theoretical models to improve our understanding of the effects of fiscal policies, and it provides a brief survey of the two relevant literatures. Section III introduces the seven structural models, and the seven standardized specifications of temporary fiscal shocks. Section IV provides extensive multiplier estimates using simulations of the models. Section V discusses the effects of permanent changes of fiscal instruments and of government debt, using simulations of two of the models. Section VI uses simulations of three of the models to quantify the worldwide effects of the G20 stimulus packages that have been announced for 2009 and 2010. Section VII provides concluding comments.

\section{Fiscal Multipliers: Empirical and Model-Based Evidence}

Our knowledge of the effects of fiscal policy comes from two sources, reduced-form empirical exercises and structural models.

Reduced-form empirical work has produced empirical estimates of fiscal multipliers that are dispersed over a very broad range, and this finding pertains both to government spending shocks and discretionary tax changes. ${ }^{2}$ In studies that pay close attention to the identification of fiscal stimulus in the United States (Blanchard and Perotti 2002, and Romer and Romer 2008), a fiscal stimulus of one percent of GDP has been found to increase GDP by close to one percent on impact and by as much as 2 to 3 percent when the effect peaks a few years later. On the other hand, Perotti (2005) finds much smaller multipliers for European countries using the same identification strategy as in Blanchard and Perotti (2002). Cross-country studies often find small fiscal multipliers and in some

\footnotetext{
${ }^{2}$ See Spilimbergo and others (2009) for a more extensive survey of the literature.
} 
cases multipliers with a negative sign (Christiansen 2008). The most notable studies with negative multipliers are found in the literature on expansionary fiscal contractions initiated by Giavazzi and Pagano (1990) and surveyed in Hemming, Kell and Mahfouz (2002). In recent work, Mountford and Uhlig (2009) find substantial multipliers for the United States that are comparable to those of Blanchard and Perotti (2002), but emphazise that the multipliers associated with tax cuts are much higher than those associated with changes in spending. According to the results in Mountford and Uhlig (2009), private consumption does not react much to increases in government spending, and consequently the spending multiplier is low. In the evidence provided by Blanchard and Perotti (2002) and Galí, López-Salido and Vallés (2007), private consumption rises significantly after a positive spending shock and these papers therefore obtain considerably larger spending multipliers. On balance, the evidence provides some support for the view that, in the current environment where monetary policy remains accommodative, a well-executed global fiscal stimulus could provide an appreciable boost to aggregate demand in the world economy, although there is some disagreement about the appropriate mix of government spending and tax cuts.

Empirical studies provide valuable information for policymakers in normal situations, but in the current situation when policy rates are likely to remain low for a prolonged period of time, one obvious and important limitation of the empirical evidence is the presumption that monetary policy will be non-accommodative and act by raising nominal and real interest rates. More generally, it can also be argued that empirical studies suffer from the following four major problems. First, the amount of available identifying information is often very small, making estimation results subject to considerable uncertainty. Second, there are many possibilities for omitted variable bias and reverse causation (most notably the two-way linkages between economic activity and fiscal balances), which reduce confidence in the results. Third, the amount of identifying information is far too small to allow us to say very much about issues like the interaction between monetary and fiscal policies, the distinction between different types of fiscal instruments, the distinction between automatic stabilizers and discretionary stimulus, leakages into imports, the effects of government financing constraints due to insufficient "fiscal space", and other forces that cause variations in multipliers. Cross-country econometric studies of fiscal multipliers have not been able to adequately control for these possibilities, and this may be a major reason why they have tended to find lower multipliers than in the United States. Fourth and finally, the existing empirical literature has not typically accounted for the fact that many fiscal actions are known prior to their implementation, and the work of Leeper, Walker and Yang (2009) shows that econometric analyses that fail to take this into account can produce distorted results about the effects of fiscal actions.

Given these difficulties with the empirical evidence, structural models could be a potentially valuable additional source of information. Structural models, particularly models that have been used heavily in policymaking institutions and that have therefore been applied to a variety of policy questions over the years, are identified using more than variation in fiscal policy. They can therefore bring a lot more evidence to bear in learning about the structure of the economy, and can then use that knowledge to deduce the likely effects of fiscal policy. This knowledge is reflected in the choice of the model structure itself, which would typically have been adapted to generate empirically valid correlations between key macroeconomic variables, and also in the calibration, which is always based 
on a great variety of sources of empirical evidence. In this regard, it is perhaps not entirely surprising that the fiscal multipliers in the structural models considered here typically are in the mid-range of the fiscal multipliers reported in the empirical literature discussed above. Of course, structural models also have weaknesses, most importantly the fact that there is only incomplete consensus on the most appropriate structural features and calibration, and these could have a material effect on the results. This however is precisely where this paper makes one of its most valuable contributions, by finding that there is considerable agreement across models on both the absolute and relative sizes of different types of fiscal multipliers. The other key contribution is that our analysis clarifies several key elements that should be important in enhancing the effectiveness of the stimulative fiscal actions.

Given the importance of this topic, several recent papers have used theoretical models to analyze the effects of fiscal stimulus. Cogan and others (2009) claim that the conclusions regarding fiscal stimulus of policy models currently used in practice, including FRB-US, are not robust, and that standard New Keynesian models such as Smets and Wouters (2007) produce much smaller multipliers. Our results do not support this view, as

FRB-US is one of the seven models used in our comparison, and as its results are found to be broadly consistent with those of the other models. One explanation is that, unlike Cogan and others (2009), our comparison models feature hand-to-mouth agents, which are absent in Smets and Wouters (2007). But more importantly, Cogan and others (2009) focus mostly on the longer-run multipliers of permanent fiscal shocks, while our focus is on the impact multipliers of temporary fiscal shocks, where the differences between models are much smaller. We will turn to an explicit comparison between the multipliers of temporary and permanent fiscal stimulus shocks in Section V, where we find that the much larger negative wealth effects of permanent shocks substantially reduce their initial period multipliers. Corsetti and others (2009) discuss the possibility that the anticipation of post-stimulus spending reversals can help to crowd-in rather than crowd-out private consumption. Again, our design of fiscal stimulus in Section IV is as an explicitly temporary measure, and Section V contains the comparison with permanent stimulus that is consistent with the point made by Corsetti and others (2009). Christiano and others (2009) stress, as we do in this paper, that the government spending multiplier becomes very much larger when higher spending is accompanied by monetary accommodation. We note that all of the foregoing theoretical contributions focus almost exclusively on government spending as the single tool of fiscal policy, while this study allows for a number of other instruments.

\section{Multipliers, Instruments, and Models}

\section{A. Definition of Fiscal Multipliers}

The term fiscal multiplier has been used in a variety of ways in the literature. Broadly speaking, it describes the effects of changes in fiscal instruments on real GDP. Typically, it is defined as the ratio of the change in real GDP to the change in the fiscal balance. In this paper, we compare the effects on real GDP of different fiscal instruments. We therefore normalize the fiscal impulses in the experiments so that the size of the 
discretionary shock in each case represents an increase in expenditures or a decline in revenues equal to 1 percent of baseline, pre-stimulus GDP, for either one year or two years. Government deficits respond endogenously to the fiscal actions because of automatic stabilizers, so that the post-stimulus change in the deficits is less than the discretionary fiscal stimulus. ${ }^{3}$ We measure the multiplier as the percentage deviation of real GDP from baseline GDP as a result of the fiscal shock.

Throughout the simulations, it is assumed that there is a coordinated global monetary policy response. Monetary policy in each country is determined by an interest rate rule, where interest rates are allowed to either adjust freely in line with the central bank's reaction function or are held fixed for one or two years.

On those occasions when the economy is operating at or near full capacity and fiscal stimulus is inappropriate, one would expect monetary policy to set interest rates on the basis of the reaction function in order to prevent the fiscal stimulus from leading to an overheated economy and upward pressure on inflation. That is, central banks would raise interest rates to offset the expansionary and inflationary implications of the fiscal expansion in such circumstances. In contrast, when the economy is in a serious recession, with interest rates at their floor of zero or a small positive value and with a risk of deflation, it is appropriate for monetary policy to hold interest rates constant during the period of fiscal expansion, because in that case the two macroeconomic policies can act in a complementary way. Clearly the second scenario describes recent events better than the first. Policymakers should of course not lose sight of the risk that, if monetary accommodation is maintained for too long, inflation expectations could become unanchored, and could rise persistently above long-run inflation objectives. A critical feature that determines how far monetary accommodation can go is therefore the policy credibility that a central bank has been able to earn during the pre-crisis period. ${ }^{4}$

\section{B. The Seven Fiscal Instruments}

The simulations of the structural models examine changes in seven fiscal instruments. These are

- an increase in government investment expenditures

- an increase in government consumption expenditures

- an increase in general lump sum transfers

- an increase in lump sum transfers targeted to hand-to-mouth households ${ }^{5}$

- a decrease in labor income tax rates

\footnotetext{
${ }^{3}$ Because of different tax and expenditure arrangements, the endogenous responses of automatic stabilizers can be an important factor in the variation of the size of multipliers across countries.

${ }^{4}$ See Alichi and others (2009).

${ }^{5}$ The definition of hand-to-mouth households in most models is as agents that are completely unable to borrow or lend. But some models have alternative definitions, including a limitation to use only cash for consumption-smoothing, or a credit constraint based on housing wealth. Table 1 and the next subsection contain more details.
} 
- a decrease in consumption tax rates

- a decrease in corporate income tax rates

\section{The Seven Structural Models}

Six institutions participated in this project using seven structural models - the European Commission (QUEST), the International Monetary Fund (GIMF), the Board of Governors of the Federal Reserve System (with two models, FRB-US and SIGMA), the Bank of Canada (BoC-GEM), the European Central Bank (NAWM), and the OECD (OECD Fiscal). Of the seven models, four are global (BoC-GEM, GIMF, QUEST and SIGMA), NAWM is a two-region model (United States and the euro area), FRB-US is a U.S. only model, and OECD Fiscal is a euro-area-only model. Six of the models are dynamic stochastic general equilibrium (DSGE) models, while FRB-US is based on the polynomial adjustment cost (PAC) framework. This explains that model's fairly smooth consumption response to stimulus shocks despite a high share of hand-to-mouth households. Two of the models, QUEST and GIMF, use their annual versions for the simulations presented here, while the remainder uses quarterly versions.

Table 1 summarizes the key model features of the seven models, including the number of regions covered, the proportion of hand-to-mouth households, the type of monetary policy rule, certain special features, and references to papers that more thoroughly outline the models and their properties.

\section{Fiscal Multipliers for Temporary Stimulus}

\section{A. Introduction to Simulation Results}

Figures 1 to 42 show the effects on U.S. real GDP, inflation, real interest rates, consumption and investment of the various instruments of U.S. fiscal stimulus. The simulations examine both one year of fiscal stimulus (figures 1 to 21 ) and two years of fiscal stimulus (figures 22 to 42). For each duration there are three charts for each of the seven fiscal instruments. Each chart compares the cases of no monetary accommodation (top panel), one year of monetary accommodation (middle panel) and two years of monetary accommodation (bottom panel). Not all models are used in all of these experiments. For example, the OECD Fiscal model is not used in any of these shocks since it covers only the euro area, the experiments with consumption tax cuts can be done only in QUEST, GIMF and NAWM, while those with corporate income tax cuts can be done with the first two models as well as SIGMA and BoC-GEM.

Figures 43 to 84 show the same results for the euro area or the EU, depending on the model. ${ }^{6}$ Most of these simulations were done using four models - QUEST, GIMF, NAWM

\footnotetext{
${ }^{6}$ Of the models which include a separate region for Europe, GIMF, NAWM and OECD Fiscal focus on the euro area while QUEST focuses on the European Union as a whole. In terms of acronyms, we will henceforth represent both of these by EU.
} 
and OECD Fiscal. The experiments with corporate income tax cuts in Europe were done only with QUEST and GIMF.

Figures 85 through 87 illustrate the results of two years of fiscal stimulus in the form of government investment in Europe and the United States on the GDP, inflation, real interest rates, consumption and investment of the two economic areas, assuming two years of monetary accommodation. These results are for fiscal stimulus in each area but not in both areas at the same time. This allows us to more easily compare fiscal multipliers for domestic stimulus in these two economic areas.

The magnitude of the fiscal multipliers in these simulations is highly dependent on both the structural features and details of the calibration of the underlying models. The impossibility of accounting for such details in empirical work may be an important reason why reduced-form empirical estimates are dispersed over such a wide range. The factors that are most evident in the simulations and that will be examined in some detail later in this section are the following: (i) the extent of monetary accommodation; (ii) the persistence of the fiscal stimulus; (iii) the type of fiscal instrument used and the channels through which the instrument operates; (iv) the population share of hand-to-mouth households; (v) the effect of targeting transfers to hand-to-mouth households; (vi) the role of economic openness; (vii) the degree of nominal rigidity of prices and wages; and (viii) the size of automatic stabilizers.

\section{B. Government Investment - Detailed Discussion}

Before examining each of these factors, we will examine in some detail two sets of simulation results, those pertaining to government investment in the United States and Europe, in order to illustrate the conclusions that can be drawn from this type of analysis.

Figure 1 shows the effects on U.S. real GDP of one year of fiscal stimulus in the form of government investment, figure 2 shows the effect of the same action on U.S. inflation and real interest rates, and figure 3 sets out its effects on U.S. consumption and investment. Figures 22 to 24 do the same for a program of two years of government investment.

As noted, the top panel in each figure shows the results of temporary fiscal stimulative actions under no monetary accommodation, the middle panel under one year of monetary accommodation and the bottom panel under two years of monetary accommodation. If the fiscal stimulus were undertaken in circumstances in which output was at or very near to capacity, one would expect the central bank to respond to the stimulus in line with the typical Taylor-type reaction function and to raise its policy interest rate in a way that would lessen the impact on output and inflation of the inappropriately-timed fiscal stimulus. In contrast, in circumstances in which aggregate demand is very weak, the economy is well below capacity output and is expected to remain there for some time, and in which the policy interest rate is at or near the zero lower bound, a policy of monetary accommodation for one or preferably two years would be appropriate to the circumstances. By not acting to offset the stimulative effects of fiscal policy, the central bank allows the temporary fiscal actions to have a considerably larger effect on the economy than if it acted in line with its normal reaction function. 
That said, the central bank must be sensitive to the risk that its inaction could result in inflation expectations ratcheting upward to a level above the long-term inflation objective and remaining there. It would therefore be very helpful in such circumstances for the central bank to have policy credibility so that inflation expectations remain anchored at a low level, for the monetary accommodation to be viewed as temporary, and for the stimulative fiscal actions also to be viewed as temporary and as appropriate in the context of a very weak economy. ${ }^{7}$ In the absence of such a favorable environment, monetary accommodation could have adverse effects over time and result in inflation pressures that lead to the inflation rate overshooting its target and eventually requiring appreciable monetary tightening. The clearly positive benefits of monetary accommodation throughout this paper must be understood in the context of a favorable monetary policy environment, and the results would have to be qualified in the absence of such an environment.

We begin by examining the case of one year of fiscal stimulus in figure 1. For the case of no monetary accommodation, the multipliers for the first year are similar in all six models, ranging between 0.9 and 1.3. As we move from no monetary accommodation to one year of monetary accommodation to two years of monetary accommodation, the multipliers become larger and the differences between the results of the various models become more noticeable. In the case of two years of fiscal stimulus (figure 22), the differences across the models are even more noticeable, particularly in the case of two years of monetary accommodation, where the spread is much wider between the largest multiplier (about 2.2 in GIMF) and the smallest multiplier (about 1.1 in FRB-US).

The reasons for these disparities relate in large part to differences in the effects of the fiscal stimulus on inflation and the real interest rate. Thus, returning to the case of one-year fiscal stimulus in figure 2, we see that the effect on inflation differs considerably across the models, with the largest effect coming from GIMF, especially with monetary accommodation. This is mostly due to the fact that GIMF has somewhat smaller nominal rigidities than the other models. As a result, the effect on the real interest rate with monetary accommodation is largest in GIMF, with a decline of about 2.2 percent in the case of two years of monetary accommodation, followed by BoC-GEM at 1.2 percent. Qualitatively similar, but quantitatively even more pronounced, differences in the effects on inflation and real interest rates can be found for the simulations of two years of fiscal stimulus in figure 23. Interestingly, the variation of real interest rate movements also tends to be significant across models in the case of no monetary accommodation, mainly reflecting differences in the reaction functions embedded in the various models.

Significant differences in the models can also be seen in the behavior of consumption and investment. Figures 3 and 24 show that in most cases GIMF has the largest effects on consumption and FRB-US shows the largest effects on investment. The consumption effects in models with a significant share of hand-to-mouth households (or of credit-constrained and finitely-lived households) are larger. Hand-to-mouth agents in NAWM can smooth consumption much more effectively than in other models because they can use cash for that purpose.

\footnotetext{
${ }^{7}$ For an analysis of the implications of imperfect policy credibility on central bank behavior in an inflation targeting regime, see Alichi and others (2009).
} 
Important recent papers such as Cogan and others (2009) have expressed skepticism about the size of fiscal multipliers, based on the fact that for permanent government spending shocks households experience large and immediate negative wealth effects due to their anticipation of a much higher tax burden in the future. In that case multipliers are well below one and start to decline immediately. This contrasts sharply with our results because stimulus only lasts for one or two years, so that the wealth effects are minimal while the direct stimulus to aggregate demand is large. We will return to this point in Section V.

Again because of the temporary nature of the stimulus, the persistence of private demand beyond the stimulus period is small. Given the small wealth effects, only hand-to-mouth (and to some extent finitely-lived) households respond significantly to the income generating effects of the stimulus, and stop doing so when it expires. We do observe some persistence in BoC-GEM, GIMF and QUEST, but this is driven by the supply side, as these three models feature productive government investment that has highly persistent output effects. These are, however, not very large given the short duration of the stimulus period.

We can also examine the output effects of an equal sized fiscal stimulus in the four models that have a separate region for Europe (figures 43 and 64). For the case of no monetary accommodation, the multipliers for the first year are, again, very similar across models, around 1, and in a slightly narrower range than in the case of the United States. Once again, more monetary accommodation leads to larger GDP responses, while the variation across models is less than in the case of the United States. Consider the case of two years of fiscal stimulus, with 2 years of monetary accommodation, where the largest multiplier is from OECD Fiscal (about 1.6 on average), followed by QUEST (over 1.5), and the smallest is from NAWM (about 1.1). The multipliers in these cases are lower than their U.S. counterparts because the real interest rate exhibits much smaller movements as a result of smaller inflation responses (see figure 23 versus figure 65 for the case of two years of fiscal stimulus). The reason is an assumption of stronger nominal rigidities in the price and wage processes for Europe compared to the United States, resulting in greater inflation inertia. This is of course based on observed differences in inflation inertia in the data. The three models that produce simulations for both the United States and Europe (QUEST, NAWM and GIMF) do assume significant differences in nominal rigidities between these two regions.

European consumption and investment behavior can be seen in figures 45 and 66 . Consumption is usually more important, with the exception of OECD Fiscal, where investment expands more strongly, because it features a stronger link between the real interest rate and the level of investment than in the other models.

\section{The Role of Monetary Accommodation}

For each figure showing the effect of fiscal stimulus on real GDP, moving from the top panel (no monetary accommodation) to the middle panel (one year of monetary accommodation) to the bottom panel (two years of monetary accommodation), there is a tendency for multipliers to increase. The reason is that, in addition to their direct effects on aggregate demand, fiscal stimulus measures also have indirect effects on aggregate 
demand through their impact on real interest rates. The fiscal action leads to an increase in inflationary pressure as aggregate demand increases, which in turn leads to a movement in real interest rates. With no monetary accommodation, the inflation pressures lead to an upward movement in real interest rates and thereby offset, in part, the effects of the fiscal stimulus on GDP. In contrast, with monetary accommodation and nominal interest rates held constant, the increases in inflation give rise to decreases in real interest rates. As a result, accommodative monetary policy complements the fiscal policy stimulus and intensifies its effects on real GDP. The indirect effects differ more across models than the direct effects, because of the differences in the size of the linkage between aggregate demand and inflation. In the case of the United States, inflationary pressures and, consequently, real interest rate movements, are largest in GIMF and BoC-GEM, and smallest in FRB-US and NAWM. In the case of Europe, they are largest in GIMF, and then generally, followed by QUEST, OECD Fiscal and NAWM. Overall, monetary accommodation is less effective in Europe, mostly because of stronger nominal rigidities than in the United States.

\section{The Persistence of Fiscal Stimulus}

The size of the multiplier will depend on the expected persistence of the fiscal stimulus measure. Our focus for most of the paper is on fiscal expansions that are, and are perceived to be, temporary, and that therefore do not result in long-run crowding out of private spending. ${ }^{8}$ In such cases, a two-year expansion will have significantly larger multiplier effects than a one-year expansion even in the first year, but only under monetary accommodation. The reason is that a more persistent boost to demand creates higher inflation over a longer period, thereby causing a more powerful reduction of real interest rates.

Compare, for example, figures 22 and 23 with figures 1 and 2 for the United States and figures 64 and 65 with figures 43 and 44 for Europe. In each case, the expectation of two years of fiscal stimulus results in a large increase in the size of the multiplier even in the first year of the stimulus. But in the case of Europe the differences are smaller than in the United States, as the stronger nominal rigidities in Europe limit the effect of higher demand on inflation and real interest rates.

As we will see later, fiscal expansions that are expected to last indefinitely typically have much smaller multipliers. This is because they result in a much larger increase in the present discounted value of taxes, and therefore a much larger negative wealth effect that crowds out private spending from the outset. Stimulus is therefore at its most effective over an intermediate horizon and in combination with monetary policy. In that case its direct demand and income generating effects, and its interactions with monetary accommodation, are more powerful than its wealth effects.

\footnotetext{
${ }^{8}$ Following the withdrawal of temporary fiscal stimulus in the models, there is a reduction in general transfers in order to bring the ratio of debt to GDP back to its baseline value. There is therefore no problem with respect to the sustainability of the fiscal position and the credibility of the fiscal authorities.
} 


\section{E. Government Spending versus Taxes and Transfers}

Different types of fiscal measures operate on aggregate demand through different channels. Thus, government investment and government consumption impact directly on aggregate demand while increases in transfers and reductions in taxes operate mainly through their effects on personal disposable incomes, as well as through their effects on incentives in the case of changes in distortionary taxes. It is widely accepted in the literature that fiscal measures that have direct effects on aggregate demand have larger multipliers than those whose initial impact operates through their effects on private-sector spending behavior. This is confirmed by our simulations. For the United States, compare figures 22 and 25, on the one hand, with figures 28,31, 34, 37 and 40 on the other. For Europe, compare figures 64 and 67, on the one hand, with figures 70, 73, 76, 79 and 82 on the other. A number of results are consistent across all models.

First, the multipliers from government investment and consumption, which are roughly similar in size, are clearly larger than the multipliers from transfers, labor income taxes, consumption taxes and corporate income taxes.

Second, multipliers are small for general transfers, labor income taxes and corporate income taxes, and somewhat larger (but still small relative to government spending) for consumption taxes.

Third, only targeted transfers (figures 31 and 73), which we will discuss again shortly, come close to having multipliers similar to those of government spending.

\section{F. Different Taxes and Transfers}

The responses to tax and transfer-based stimulus measures depend critically on two factors, the behavior of hand-to-mouth households and the relative distortions caused by different fiscal instruments.

We start our discussion of the importance of hand-to-mouth households under the assumption that stimulus is based on general transfers, which cause no distortions. Spending of hand-to-mouth households responds strongly to transfer changes in all models, while other households respond to the temporary nature of the transfer change largely by adjusting their saving behavior. In all but two of the models these other households are infinitely-lived, and therefore see future transfer cuts as exactly offsetting the current transfer increase, with their consumption not affected at all. In GIMF a temporary increase in transfers has some effects on other households because they have finite lives and therefore interpret part of the transfers as an increase in lifetime wealth. BoC-GEM generates a similar non-Ricardian feature by positing a link between net foreign assets and government debt. But for realistic planning horizons of finitely-lived agents this effect, while significant, is much smaller than the effect on hand-to-mouth households. The share of the latter in the population, and the precise nature in which they are constrained, are therefore critical determinants of the response of the economy to transfer shocks, and also to tax shocks. 
Turning to distortionary tax cuts as the instrument of stimulus, these have additional effects on supply and therefore on inflation and real interest rates, but these effects differ significantly across instruments. For example, the output effects of temporary cuts in labour income tax rates are not very large, and in fact are smaller than for general transfers under monetary accommodation. This is because they increase potential output, which reduces the inflationary effects of the stimulus and therefore the effectiveness of monetary accommodation. Similar comments apply to cuts in corporate income taxes. In contrast, the simulations suggest that the incentives for increased household spending from temporary cuts in consumption taxes are significantly larger.

\section{G. General Transfers versus Targeted Transfers}

Hand-to-mouth households have a much higher marginal propensity to consume out of current income than other households. This has two implications. First, models that have a high share of hand-to-mouth households have a higher multiplier for general transfers (and also for taxes). Second, transfers that can be targeted to hand-to-mouth households provide a much more powerful stimulus than general transfers.

Temporary increases in general transfers are presented in figures 7 and 28 for the United States and figures 49 and 70 for Europe. The multipliers for this measure are small in absolute terms across all models, but are larger in those models that have a higher share of hand-to-mouth households. Thus, FRB-US (40 percent for US), SIGMA (50 percent for US) and QUEST (40 percent for US and EU - this includes both hand-to-mouth and credit-constrained households) tend to have larger multipliers than the other three models - BoC-GEM (15 percent for US, 25 percent for EU), GIMF (25 percent for US and EU), NAWM (25 percent for US and EU) and OECD Fiscal (25 percent for EU).

Temporary increases in targeted transfers are presented in figures 10 and 31 for the United States and figures 52 and 73 for Europe. Multipliers increase sharply relative to general transfers, and in fact targeted transfers multipliers are close to (but somewhat lower than) those of government spending. The increase in multipliers from targeting transfers tends to be greatest in those models that have the lowest percentage of hand-to-mouth households, especially BoC-GEM and GIMF. The reason is that shifting the total value of the increase in transfers from the general public to the targeted groups leads to a larger increase in the disposable incomes of the targeted groups when they are a smaller proportion of the population.

\section{H. United States versus Europe}

Temporary fiscal stimulative actions have greater effects on output, inflation, and real interest rates in the United States than in Europe. Figures 85, 86 and 87 show the effects of two years of stimulative government investment spending in Europe (top panel - four models) and the United States (bottom panel - six models) along with two years of monetary accommodation. The larger effects in the United States could be due to a number of factors, and this section will explore which of them is most important. First, Europe is more open than the United States, and therefore the leakage to imports is 
larger. Second, automatic stabilizers play a larger role in Europe than in the United States, and therefore the leakage from the discretionary fiscal stimulus into higher taxes and lower transfers is greater in Europe. Third, the degree of nominal rigidities is larger in Europe than in the United States, and therefore the effect of expansionary fiscal actions on the rate of inflation is lower in Europe than in the United States, leading to smaller downward movements in the real interest rate in Europe than in the United States under monetary accommodation.

We analyze the importance of these three factors by examining the effects of a two-year, one percent of baseline GDP, increase in government consumption under two years of monetary accommodation, using different calibrations of the IMF's model, GIMF. For openness we examine this shock relative to a baseline for the euro area, while for the remaining two factors we examine it relative to a baseline for the United States.

Consider first, the degree of openness of the economy. The top panel of figure 88 shows the results for the original calibration of the euro area in GIMF, with exports from the euro area of about 17.4 percent of GDP, and imports of about 17.5 percent of GDP. The bottom panel of figure 88 presents the results of the fiscal shock for a recalibrated level of exports and imports as a share of GDP of one half of the original calibration (and much smaller than the calibrated share for the U.S. economy). With the more open calibration of the euro area, real GDP is 1.2 and 1.1 percent higher than baseline in years 1 and 2, respectively, in the case of two years of monetary accommodation. In the case of the more closed economy, real GDP is somewhat larger, at 1.3 and 1.2 percent higher than baseline. In the less open economy, the increase in demand falls more heavily on the domestic sector and also leads to a larger inflation response and therefore a larger decline in real interest rates in the case of monetary accommodation. The conclusion that the more closed economy has a somewhat higher fiscal multiplier holds for all the temporary fiscal stimulus measures considered in this paper, and for the same type of experiment on the U.S. economy.

Consider next the level of nominal rigidities and the level of automatic stabilizers. Figure 89 examines three U.S. calibrations: the original calibration (top panel); an alternative where U.S. nominal rigidities have the same parameter values as in the euro area, that is they are 50 percent higher than in the original calibration (middle panel); and a third calibration to analyze the importance of automatic stabilizers in which the weight on the output gap in the fiscal policy rule is the same as in the euro area, that is it equals 0.49 instead of 0.34, the original U.S. calibration (bottom panel). Comparing the results of the original calibration with that for higher nominal rigidities, we see that inflation responds less to aggregate demand, and the real interest rate therefore also moves less under monetary accommodation. Thus, the multiplier is significantly lower with higher nominal rigidities, especially with two years of monetary accommodation. The U.S. results with higher nominal rigidities are closely in line with those seen in the GIMF simulations for Europe.

Higher automatic stabilizers reduce the effect of the government discretionary fiscal action because the resulting increase in GDP automatically reduces general transfers to households through the fiscal rule. That is, the overall increase in the fiscal deficit is smaller when automatic stabilizers are larger. The decline in the fiscal multiplier with larger automatic stabilizers is significant, but not as large as for higher nominal rigidities. 
Overall, it appears that the smaller fiscal multipliers in Europe relative to the United States in GIMF are mostly a result of the higher nominal rigidities in Europe, with the relative openness of European economies and the larger automatic stabilizers playing somewhat smaller roles.

\section{Permanently Higher Deficits and Debt}

In this section we demonstrate that, while the case for temporary fiscal stimulus, as outlined in the previous section, is strong, the case for a permanent increase in fiscal deficits is much weaker in terms of its short-run effectiveness, and its long-run consequences could be negative. For illustrative purposes, we focus on the United States, although the results hold qualitatively for each of the different regions in the models discussed below.

\section{A. Permanently Higher Deficits and Short-Run Multipliers}

We start by using the GIMF and QUEST models to compare the short-run effects of temporary and permanent increases in deficits and debt, using the United States as our example. In addition to hand-to-mouth households, GIMF features finitely-lived households, while the remaining households in QUEST are infinitely-lived. ${ }^{9}$ Figure 90 illustrates the differences in multipliers between a one-year fiscal stimulus using government consumption, and a permanent change in government consumption of the same size, one percent of baseline GDP. We assume that the permanent increase in government consumption is accompanied by a permanent increase in the government's interest-inclusive deficit to GDP ratio equal to one percent of GDP. Given our assumptions about nominal growth rates, the latter leads in the long run to a 20 percent increase in the debt to GDP ratio. Higher long-run debt implies that additional interest charges will eventually exceed the one percentage point increase in the deficit ratio. We assume that labor income taxes are adjusted to service these interest charges as well as the increase in government spending in the long run. Figure 91 illustrates the model's dynamic transition between the short run and the long run when there is a permanent increase in the debt to GDP ratio. Because this is a long-run scenario, we assume, for all experiments in this section, that there is no monetary accommodation.

The temporary fiscal stimulus has a one-year multiplier of about 1.05 in GIMF and 0.8 in QUEST (top panel of figure 90). Following the withdrawal of the fiscal stimulus, GDP remains slightly below its baseline value for some period of time in order to put downward pressure on inflation and bring it back to baseline from the levels reached during the period of stimulus.

The effect on GDP of a permanent change in the fiscal instrument is shown in the bottom panel of figure 90 . The fiscal multiplier for the first year is on the order of 0.7 in GIMF and 0.3 in QUEST, considerably less than the multiplier from the temporary fiscal

\footnotetext{
${ }^{9}$ QUEST is Ricardian in the long run, but not in the short run because of the existence of hand-to-mouth and credit-constrained households.
} 
stimulus. The numbers fall to 0.5 and less than 0.1 , respectively, in the second year. In both models multipliers turn negative in the long run due to higher distortionary taxes (in both models) and higher real interest rates (in GIMF). The next subsection discusses this in more detail. We note that the multipliers reported by Cogan and others (2009) are very similar to those in the bottom panel of figure 90. Part of their skepticism about the effectiveness of fiscal stimulus can therefore be attributed to the fact that they concentrate on permanent rather than temporary increases in spending.

To understand the differences between the short-run stimulative effects of temporary and permanent stimulus measures, we return to the fact that our permanent stimulus experiment involves much higher labor income taxes in the long run. As shown in Figure 91, this has three effects.

First, the large increase in the present discounted value of taxes leads to a negative wealth effect that immediately starts to crowd out private demand. This is the main reason behind the much smaller first-year multiplier for the permanent measure, and for the fact that the multiplier thereafter starts to fall back towards zero.

Second, if taxes are distortionary, this exacerbates the crowding-out effects. The more distortionary is the tax, the greater will be the effect on potential GDP. Thus, the use of corporate income taxes would have a larger effect than labor income taxes because of the higher long-run supply elasticity of capital. This logic also carries over to government investment spending. If this was cut in the long run to stabilize debt, there would be significant negative consequences for the long-run level of potential output because of the contribution of government infrastructure investment to private sector productivity. ${ }^{10}$

Third, in GIMF, due to finitely-lived households, part of the increase in government debt is perceived as net worth, and therefore crowds out alternative investments, specifically physical capital and (net) foreign assets, as well as resulting in a permanent increase in the world real interest rate. This makes long-run output effects more negative, as well as reducing the short-run multipliers of the permanent fiscal measure. ${ }^{11}$

\section{B. Permanently Higher Deficits and Long-Run Crowding Out}

In this subsection we use GIMF to simulate the long-run effects of a permanent 0.5 percent increase in interest-inclusive deficits that increases long-run government debt by 10 percent of GDP. GIMF is calibrated so that a one percentage point increase in the U.S. government debt-to-GDP ratio leads to an approximately one basis point increase in the U.S. and world real interest rate. This is at the lower end of the range of estimates (1 to 6 basis points) reported by Laubach (2003), Engen and Hubbard (2004) and Gale and

\footnotetext{
${ }^{10}$ Yet another possible linkage between the ratio of government debt to GDP and long-run potential output would be the increase in the risk premium on government debt in response to a rise in the debt to GDP ratio because of concerns about the long-run sustainability of the fiscal path. This relationship is not included in the models used when considering permanent changes in fiscal instruments.

${ }^{11}$ We use this long-run notion of crowding out throughout the paper. One of its major advantages is that it has a very precise meaning in terms of the models used. Other, short-run notions of crowding out are more commonly used, but they tend to conflate persistent reductions of investment that are due to purely fiscal reasons, such as permanent increases in government debt, with transitory reductions in investment that are due to other reasons, such as monetary policy.
} 
Orszag (2004). Of the other models in this paper, both QUEST and OECD Fiscal include an endogenous government debt risk premium. In QUEST, this risk premium applies to government debt interest payments, while in OECD Fiscal, as in GIMF, it applies to the economy-wide real interest rate. All models in this paper could still generate long-run crowding out effects, but in the other models this may only be due to the effects of higher distortionary taxes in the long run. ${ }^{12}$

The simulations assume that deficits are initially increased through a reduction in taxes or an increase in transfers, unlike the simulations in the previous subsection. As debt and interest charges rise, the primary deficit has to fall to keep the overall deficit increase at 0.5 percent of GDP, and this is assumed to be implemented through an offsetting increase in the same taxes or a reduction in the same transfers.

Table 2 presents the effects on real GDP in the United States, the rest of the world, and globally. As investment in the additional government debt crowds out saving in physical capital and (net) foreign assets, the world real interest rate rises by 9 to 11 basis points, and this contributes to a decline in global long-run real GDP of between 0.3 percent and 0.7 percent. The effects on real GDP in the United States are significantly larger than in the rest of the world. In the case of lower long-run transfers $(-0.30$ in the United States and -0.17 in the rest of the world), this is due to a negative wealth effect on U.S. consumption demand, from two sources. First, the United States pays higher interest charges on a pre-existing stock of foreign liabilities. And second, due to crowding out it adds further to that stock of liabilities. In the case of taxes, the differences between the United States and the rest of the world are larger because tax distortions increase in the United States but not elsewhere. The largest distortions arise in the case of corporate income taxes, due to their effect on capital accumulation, with a long-run GDP effect of $-0.71(-0.23$ in the rest of the world). The GDP effect of higher labor income taxes is -0.48 $(-0.21$ in the rest of the world), and that of consumption taxes is -0.38 ( -0.18 in the rest of the world). This corresponds closely to the rankings of alternative taxes by their distortionary effects in the public finance literature.

\section{Effects of G-20 Fiscal Packages}

Table 3 sets out the components of the fiscal stimulus packages that are being implemented over 2009 and 2010 by the G20 countries. ${ }^{13}$ Japan, emerging Asia and the United States have announced the largest packages, while the G20 countries in the euro area, Africa and Latin America have the smallest packages. In terms of the composition of the packages, general and targeted transfers dominate in Japan, government investment spending dominates in emerging Asia, and government consumption, targeted transfers and income tax cuts dominate in the United States. ${ }^{14}$ It is of interest to note that in none of the regions do increases in government consumption play a predominant role.

\footnotetext{
${ }^{12}$ Of course, depending on the size of the distortions caused by taxes, long-run crowding out in the other models could well be larger than in GIMF.

${ }^{13}$ This is compiled from data collected by the staff of the IMF, as of April 20, 2009.

${ }^{14}$ Transfers that fall under the social safety net heading in Table 3 are treated as targeted transfers for simulation purposes.
} 
Figure 92 shows the effect on GDP of the G20 fiscal stimulus packages, as simulated in three of the models - BoC-GEM, GIMF, and QUEST. The left-hand panels show the effect on the United States, the rest of the world, and globally assuming two years of monetary accommodation, while the right-hand panels show the same results assuming no monetary accommodation. All of the models show a considerable impact on GDP, especially under the assumption of monetary accommodation. And the withdrawal of fiscal stimulus at the end of 2010 results in an appreciable decline in the deviation of GDP from its baseline.

The differences in effects are very small across models in the case of no monetary accommodation, but considerably larger in the case of monetary accommodation, with BoC-GEM having the largest effects while QUEST and GIMF are relatively similar. The differences across models, as above, come primarily from the responsiveness of the rate of inflation to changes in aggregate demand and aggregate supply.

\section{Concluding Remarks}

The simulations of the seven policy models used in this study suggest that temporary fiscal stimulus can play an important role in the kind of prolonged downturn that the world is currently experiencing. ${ }^{15}$ Four conclusions stand out. First, there is a robust finding across all models that fiscal policy can have sizeable output multipliers, particularly for spending and targeted transfers. Second, the effectiveness of fiscal policy will be largest in circumstances in which monetary policy supports fiscal policy by accommodating stimulative fiscal actions through holding interest rates constant for some period of time. Third, more persistent stimulus, if the additional stimulus is measured in years rather than decades, is even more effective if monetary policy remains accommodative. Fourth, permanent fiscal stimulus has significantly lower multipliers at the outset, and has negative output effects in the long run.

It is important to emphasize this last point. Fiscal policy must be conducted in a responsible way such that the policy track is sustainable and the fiscal authorities can maintain their credibility. The implications of not acting responsibly involve both shorter-run and longer-run unfavorable outcomes. Relatedly, it is important for governments to act to reduce their debt to GDP ratios in economically favorable times to give themselves fiscal space when stimulative actions are needed in a more difficult economic environment.

\footnotetext{
${ }^{15}$ Because of the expected duration of the current downturn, implementation lags are less important than would be the case in a more typical economic downturn.
} 


\section{Appendix: Contributors}

Günter Coenen is Head of the Econometric Modelling Division of the Directorate General Research at the European Central Bank, Frankfurt, Germany.

Christopher Erceg is Assistant Director of the International Finance Division at the Board of Governors of the Federal Reserve System, Washington, D.C., U.S.A

Charles Freedman is Scholar in Residence in the Economics Department, Carleton University, Ottawa, Canada

Davide Furceri is Economist of the Macroeconomic Analysis Division at the OECD, Paris France.

Michael Kumhof is Senior Economist of the Modeling Unit of the Research Department at the International Monetary Fund, Washington, D.C., U.S.A.

René Lalonde is Modeling Advisor of the Modelling Group of the International Department at the Bank of Canada, Ottawa, Canada

Douglas Laxton is Advisor and Head of the Modeling Unit of the Research Department at the International Monetary Fund, Washington, D.C., U.S.A.

Jesper Lindé is Chief of the Trade and Financial Studies Section of the International Finance Division at the Board of Governors of the Federal Reserve System, Washington, D.C., U.S.A.

Annabelle Mourougane is Senior Economist of the Office of the Chief Economist at the OECD, Paris France

Dirk Muir is Senior Economist of the Modeling Unit of the Research Department at the International Monetary Fund, Washington, D.C., U.S.A.

Susanna Mursula is a Senior Information Management Officer of the Modeling Unit of the Research Department at the International Monetary Fund, Washington, D.C., U.S.A.

Carlos de Resende is Principal Researcher of the Modelling Group of the International Department at the Bank of Canada, Ottawa, Canada

John Roberts is Chief of the Macroeconomic and Quantitative Studies Section of the Research and Statistics Division at the Board of Governors of the Federal Reserve System, Washington, D.C., U.S.A.

Werner Roeger is Head of Econometric Models and Medium-Term studies of the Directorate General of Economic and Financial Affairs at the European Commission, Brussels, Belgium.

Stephen Snudden is Research Assistant of the Modelling Group of the International Department at the Bank of Canada, Ottawa, Canada.

Mathias Trabandt is Economist of the Fiscal Policies Division of the Directorate General Economics at the European Central Bank, Frankfurt, Germany. 
Jan in 't Veld is Head of Sector Model-Based Economic Analysis of the Directorate General of Economic and Financial Affairs at the European Commission, Brussels, Belgium 


\section{References}

Alichi, A., H. Chen, K. Clinton, C. Freedman, M.J. Johnson, O. Kamenik, T. Kişinbay and D. Laxton (2009), "Inflation Targeting Under Imperfect Policy Credibility," IMF Working Paper, WP 09/94.

Blanchard, O. and R. Perotti (2002), "An Empirical Characterization of the Dynamic Effects of Changes in Government Spending and Taxes on Output", Quarterly Journal of Economics, 117, 1329-68.

Brayton, F., and P. Tinsley (1996), "A Guide to FRB/US: A Macroeconomic Model of the United States", Board of Governors of the Federal Reserve System Finance and Economics Discussion Series 96-42.

Christiano, L., M. Eichenbaum and S. Rebelo (2009), "When is the Government Spending Multiplier Large?", Working Paper, Northwestern University.

Christiansen, L. (2008), "Fiscal Multipliers-A Review of the Literature", Appendix II to IMF Staff Position Note 08/01, Fiscal Policy for the Crisis (Washington, D.C.: International Monetary Fund).

Coenen, G., P. McAdam, and R. Straub (2008), "Tax Reform and Labour-Market Performance in the Euro Area: A Simulation-Based Analysis Using the New Area-Wide Model", Journal of Economic Dynamics and Control, 32, 2543-83.

Cogan, J.F., T. Cwik, J.B. Taylor and V. Wieland (2009), "New Keynesian versus Old Keynesian Government Spending Multipliers", NBER Working Paper 14782.

Corsetti, G., A. Meier and G. Müller (2009), "Fiscal Stimulus with Spending Reversals", IMF Working Papers, WP/09/106.

Decressin, J. and D. Laxton (2009), "Gauging Risks for Deflation", IMF Staff Position Note No. 09/01 (Washington, D.C.: International Monetary Fund).

Engen, E.M. and R.G. Hubbard (2004), "Federal Government Debt and Interest Rates", NBER Macroeconomics Annual, 19, 83-138.

Erceg, C., L. Guerrieri, and C. Gust (2005), "SIGMA: A New Open Economy Model for Policy Analysis", Board of Governors of the Federal Reserve System International Finance Discussion Paper No. 835.

Freedman, C., M. Kumhof, D. Laxton, D. Muir and S. Mursula (2010), "Fiscal Multipliers Galore", IMF Working Paper, forthcoming.

Furceri, D., and A. Mourougane (2010), "The Effects of Fiscal Policy on Output and Debt Sustainability in the Euro Area: A DSGE Analysis", OECD Working Paper (forthcoming).

Gale, W. and P. Orszag (2004), "Budget Deficits, National Saving, and Interest Rates", Brookings Papers on Economic Activity, 2, 101-187. 
Galí, J., D. López-Salido and J. Vallés (2007), "Understanding the Effects of Government Spending on Consumption", Journal of the European Economic Association, 5(1), 227-70.

Giavazzi, F. and M. Pagano (1990), "Can Severe Fiscal Contractions be Expansionary: Tales of Two Small European Countries", NBER Macroeconomics Annual, 75-122.

Hemming, R., M. Kell,.and S. Mahfouz (2002), "The Effectiveness of Fiscal Policy in Stimulating Economic Activity - A Review of the Literature", IMF Working Papers, $\mathrm{WP} / 02 / 208$.

IMF (2009a), "Global Economic Slump Challenges Policies", World Economic Outlook Update, January, World Economics and Financial Surveys (Washington, DC).

IMF (2009b), "The State of Public Finances: Outlook and Medium-Term Policies After the 2008 Crisis", Fiscal Aøairs Department. March 6. (Washington, DC).

Kumhof, M. and D. Laxton (2007), "A Party Without a Hangover? On the Effects of U.S. Fiscal Deficits", IMF Working Papers, WP/07/202.

Kumhof, M., D. Laxton, D. Muir, and S. Mursula (2010), "The Global Integrated Monetary and Fiscal Model - Theoretical Structure", IMF Working Paper, $\mathrm{WP} / 10 / 34$.

Lalonde, R. and D. Muir (2007), "The Bank of Canada's Version of the Global Economy Model (BoC-GEM)", Technical Report No. 98. (Ottawa: Bank of Canada.)

Lalonde, R., C. de Resende, and S. Snudden (2010), "The Power of Many: Assessing the Econoomic Impact of the Global Fiscal Stimulus," Bank of Canada Discussion Paper 2010-1.

Laubach, T. (2003), "New Evidence on the Interest Rate Effects of Budget Deficits and Debt", Finance and Economics Discussion Series 2003-12, Board of Governors of the Federal Reserve System.

Leeper, E., T. Walker and S. Yang (2009), "Fiscal Foresight and Information Flows", NBER Working Paper No. 14630.

Lipsky, J. (2008), "The Current Macroeconomic Outlook 2009: Issues of Systemic Stability", Speech for the Devisen Forum 2008, available at http://www.imf.org/external/np/speeches/2008/121008a.htm.

Mountford, A. and H. Uhlig (2009), "What Are the Effects of Fiscal Policy Shocks?", NBER Working Paper No. 14551.

Perotti, R. (2005), "Estimating the Effects of Fiscal Policy in OECD Countries", CEPR Discussion Paper No. 4842.

Ratto, M., W. Roeger, and J. in 't Veld (2009), "QUEST III: An Estimated Open-Economy DSGE Model of the Euro Area with Fiscal and Monetary Policy", 
Economic Modelling, 26(1), 222-33.

Roeger W. and J. in 't Veld (2009), "Fiscal Policy with Credit Constrained Households", European Economy Economic Papers No.357.

Romer, C. and D. Romer (2008), "The Macroeconomic Effects of Tax Changes:

Estimates Based on a New Measure of Fiscal Shocks", Working Paper, University of Califorina at Berkeley.

Smets, F. and R. Wouters (2007), "Shocks and Frictions in U.S. Business Cycles: A Bayesian DSGE Approach", American Economic Review, 97(3), 506-606.

Spilimbergo, A., S. Symansky, O. Blanchard, and C. Cottarelli (2008), "Fiscal Policy For the Crisis", IMF Staff Position Note 08/01.

Spilimbergo, A., S. Symansky, and M. Schindler (2009), "Fiscal Multipliers", IMF Staff Position Note 09/11. 
Figure 1. United States: Effect of 1 Year of Fiscal Stimulus on Real GDP (Instrument: Government Investment)

$$
\text { (In percent) }
$$
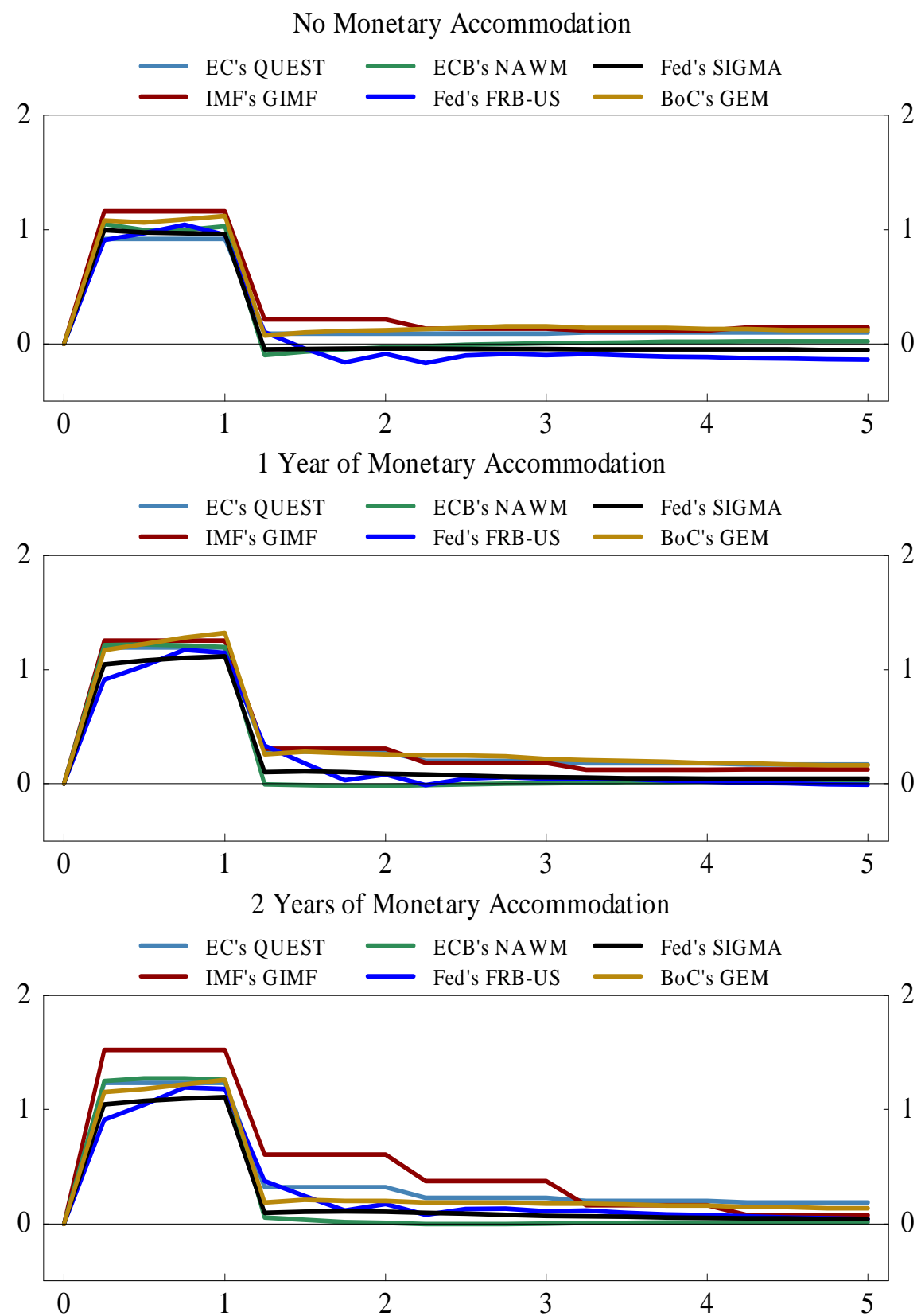
Figure 2. United States: Effect of 1 Year of Fiscal Stimulus on Inflation and the Real Interest Rate (Instrument: Government Investment)

(In percentage points)

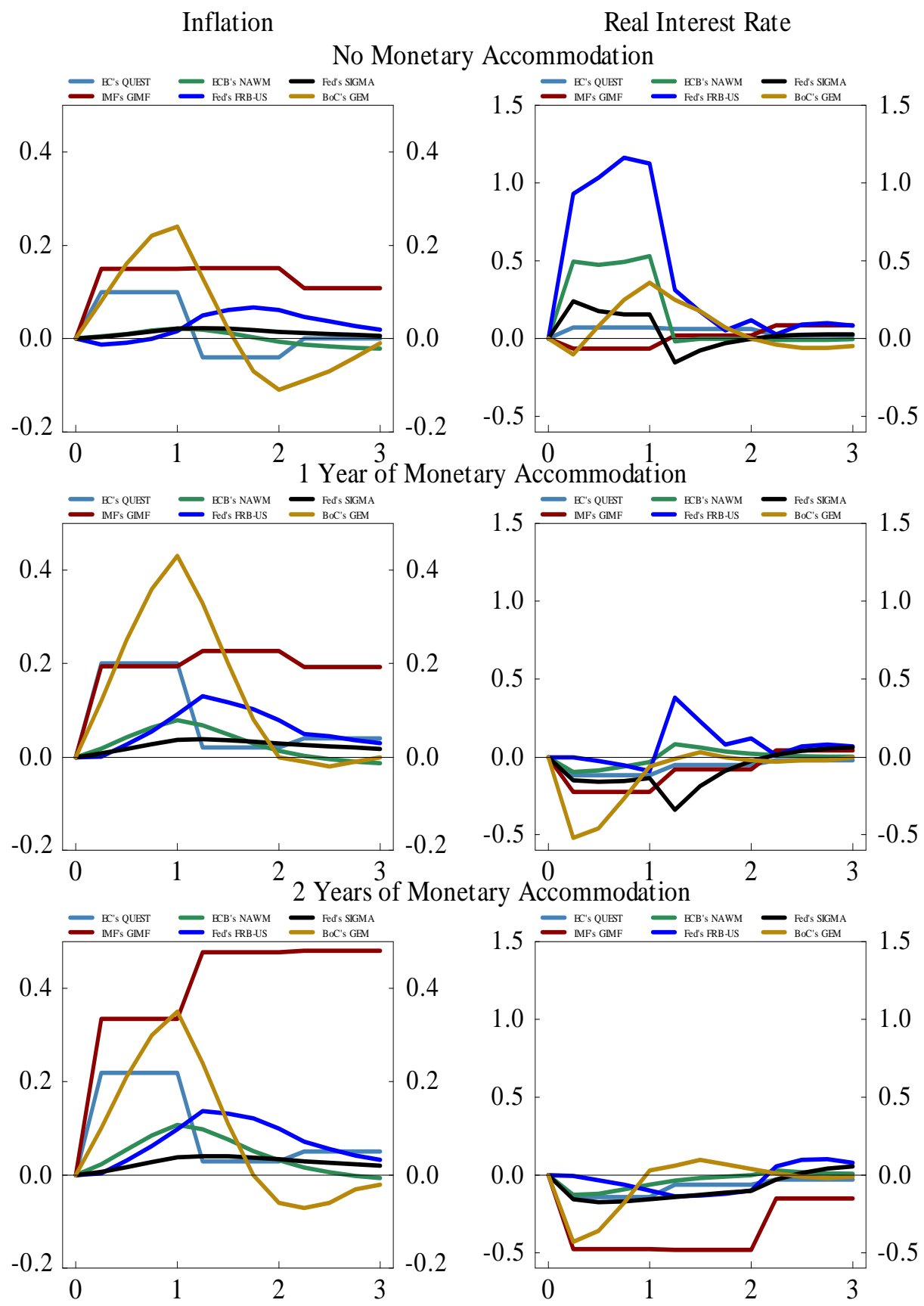


Figure 3. United States: Effect of 1 Year of Fiscal Stimulus on Consumption and Investment (Instrument: Government Investment)

$$
\text { (In percent) }
$$
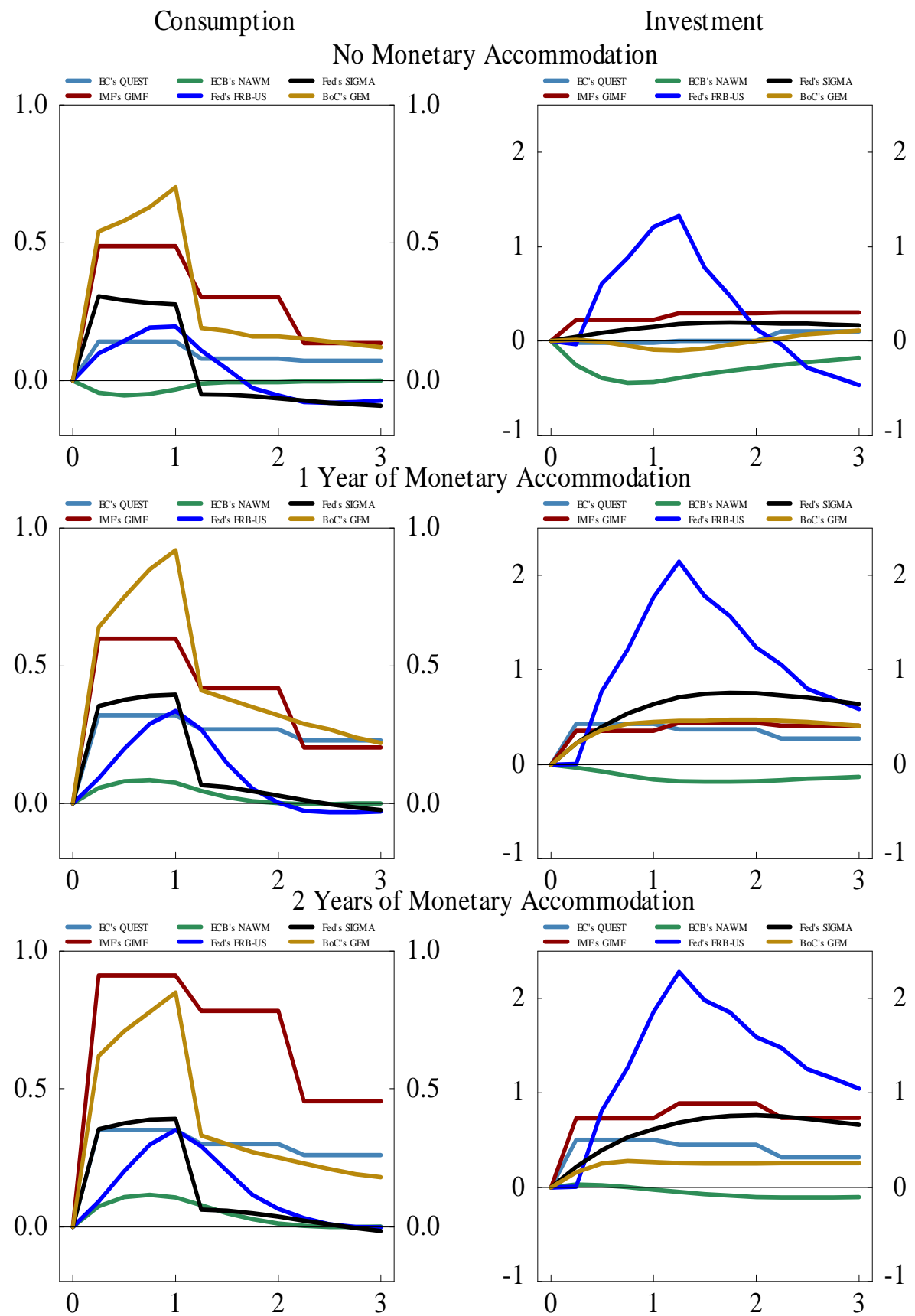
Figure 4. United States: Effect of 1 Year of Fiscal Stimulus on Real GDP (Instrument: Government Consumption)

(In percent)
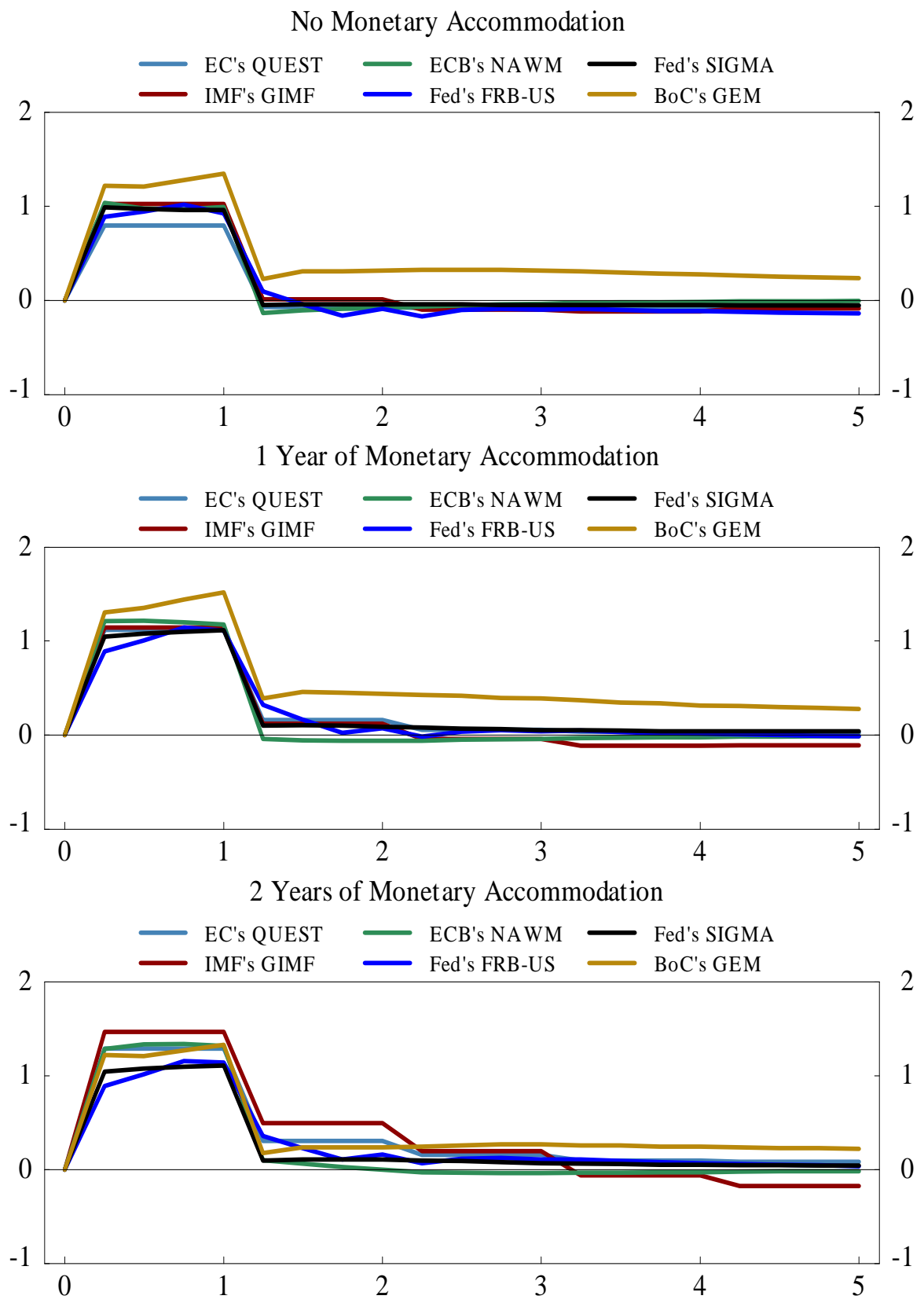
Figure 5. United States: Effect of 1 Year of Fiscal Stimulus on Inflation and the Real Interest Rate (Instrument: Government Consumption)

(In percentage points)

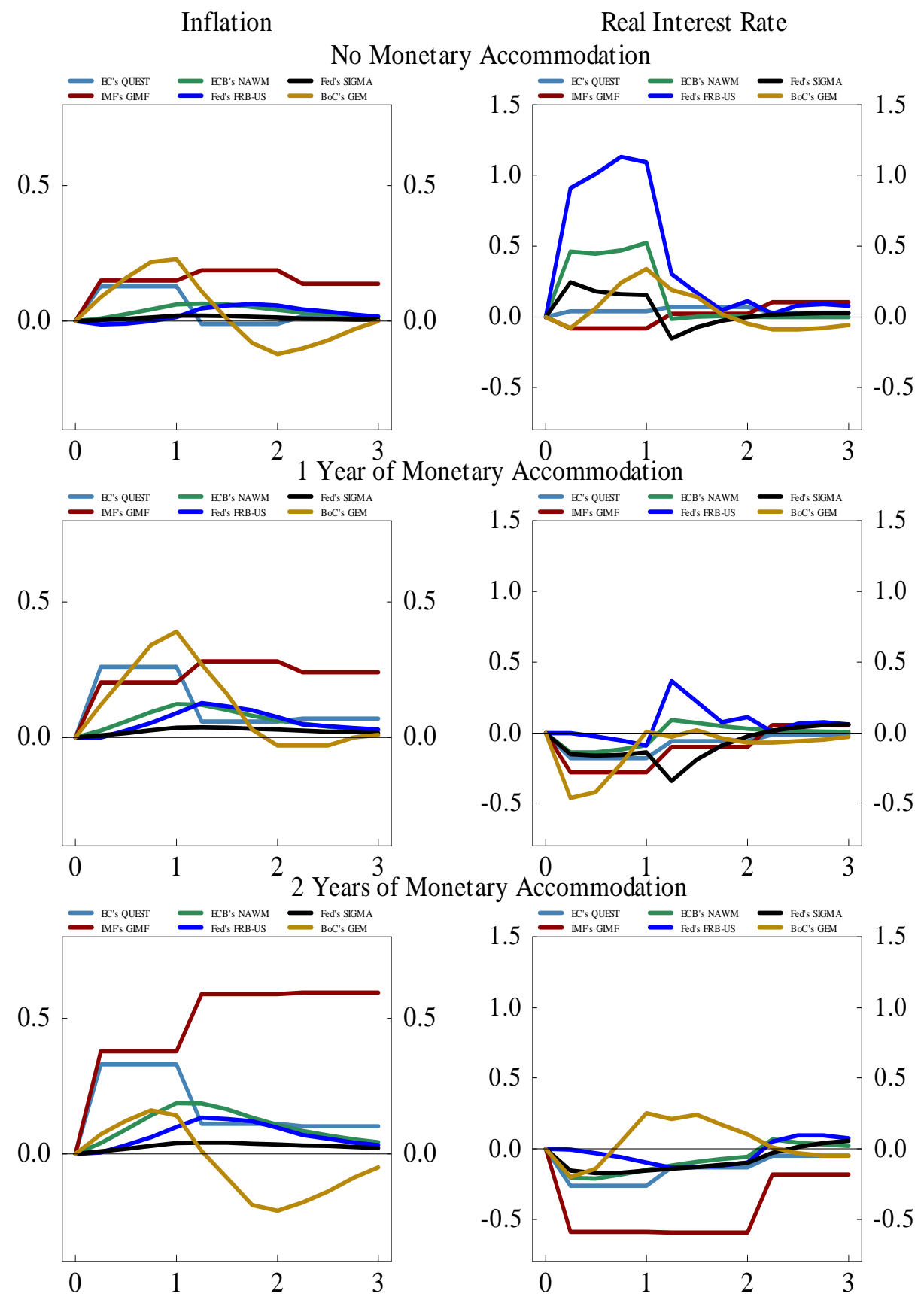


Figure 6. United States: Effect of 1 Year of Fiscal Stimulus on Consumption and Investment (Instrument: Government Consumption)

$$
\text { (In percent) }
$$
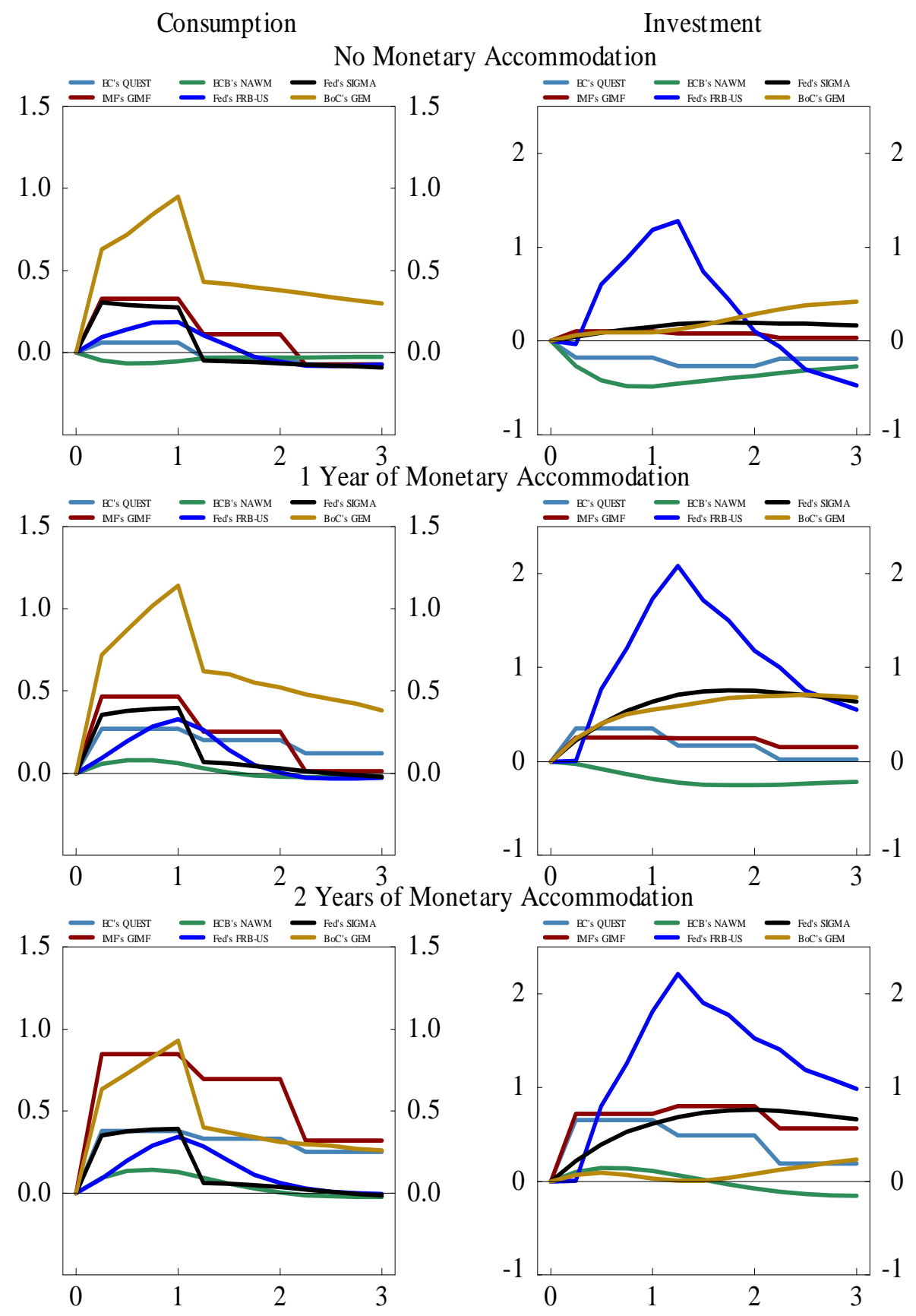
Figure 7. United States: Effect of 1 Year of Fiscal Stimulus on Real GDP (Instrument: General Transfers)

(In percent)
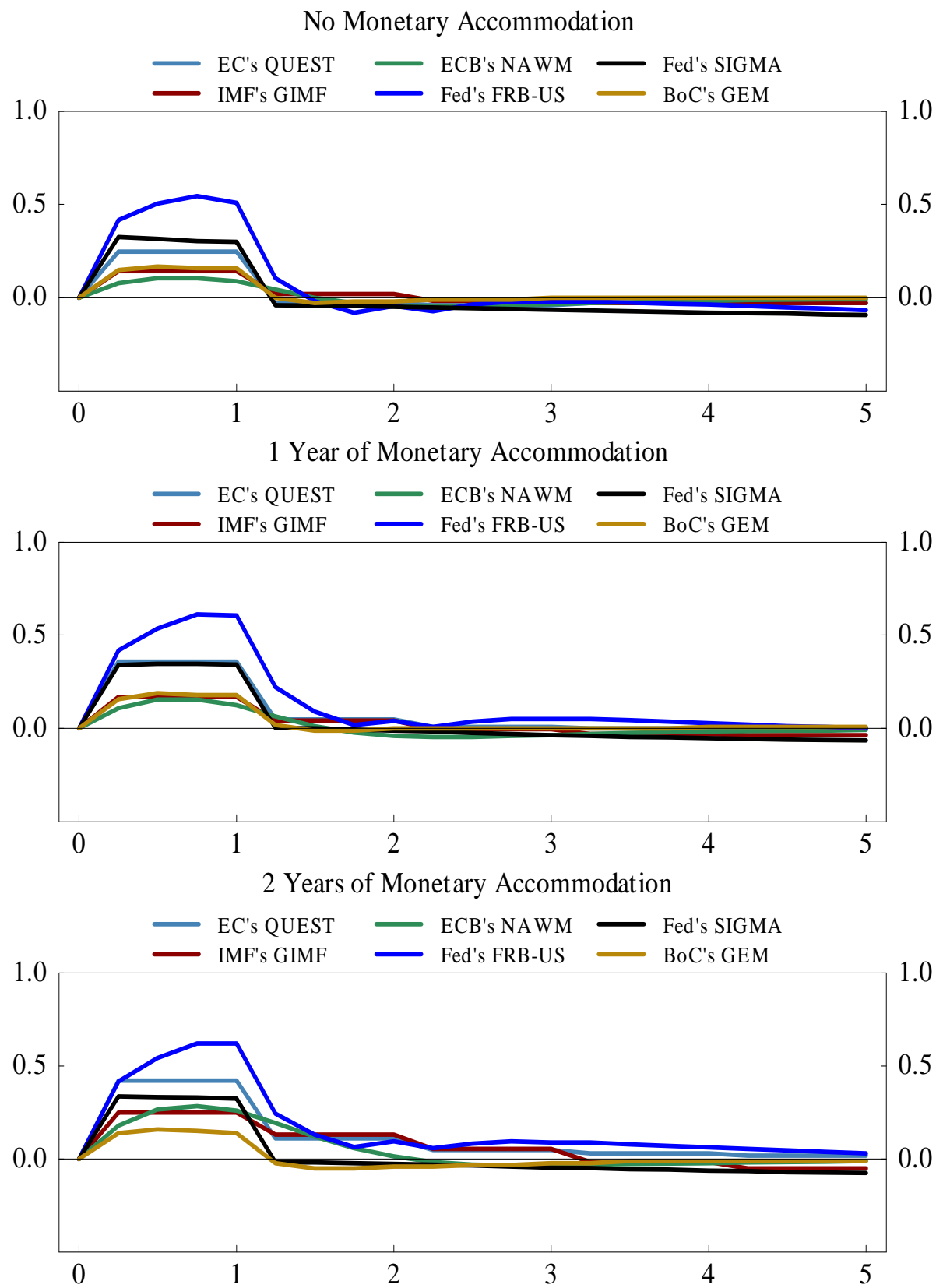
Figure 8. United States: Effect of 1 Year of Fiscal Stimulus on Inflation and the Real Interest Rate (Instrument: General Transfers)

(In percentage points)

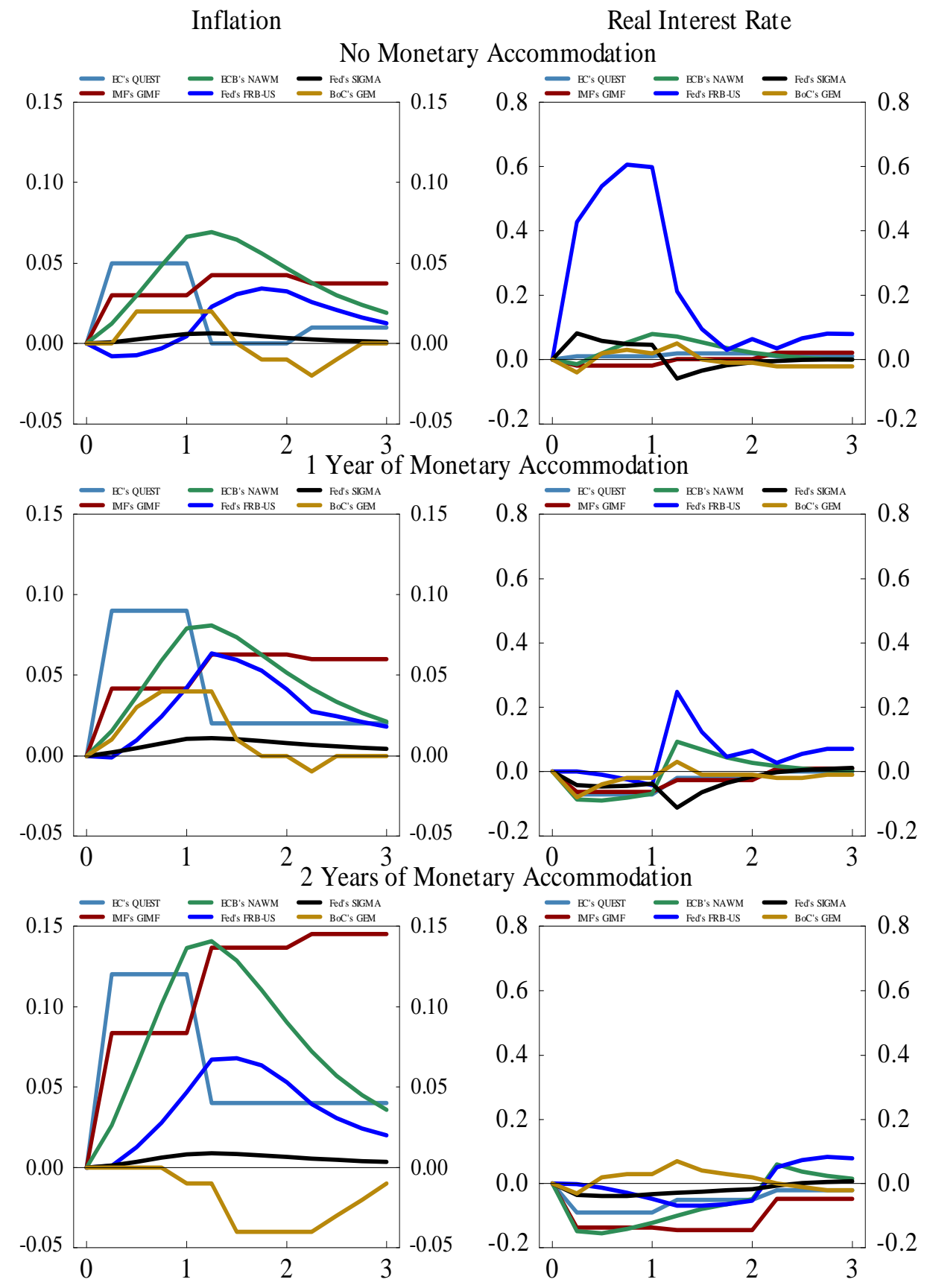


Figure 9. United States: Effect of 1 Year of Fiscal Stimulus on Consumption and Investment (Instrument: General Transfers)

$$
\text { (In percent) }
$$

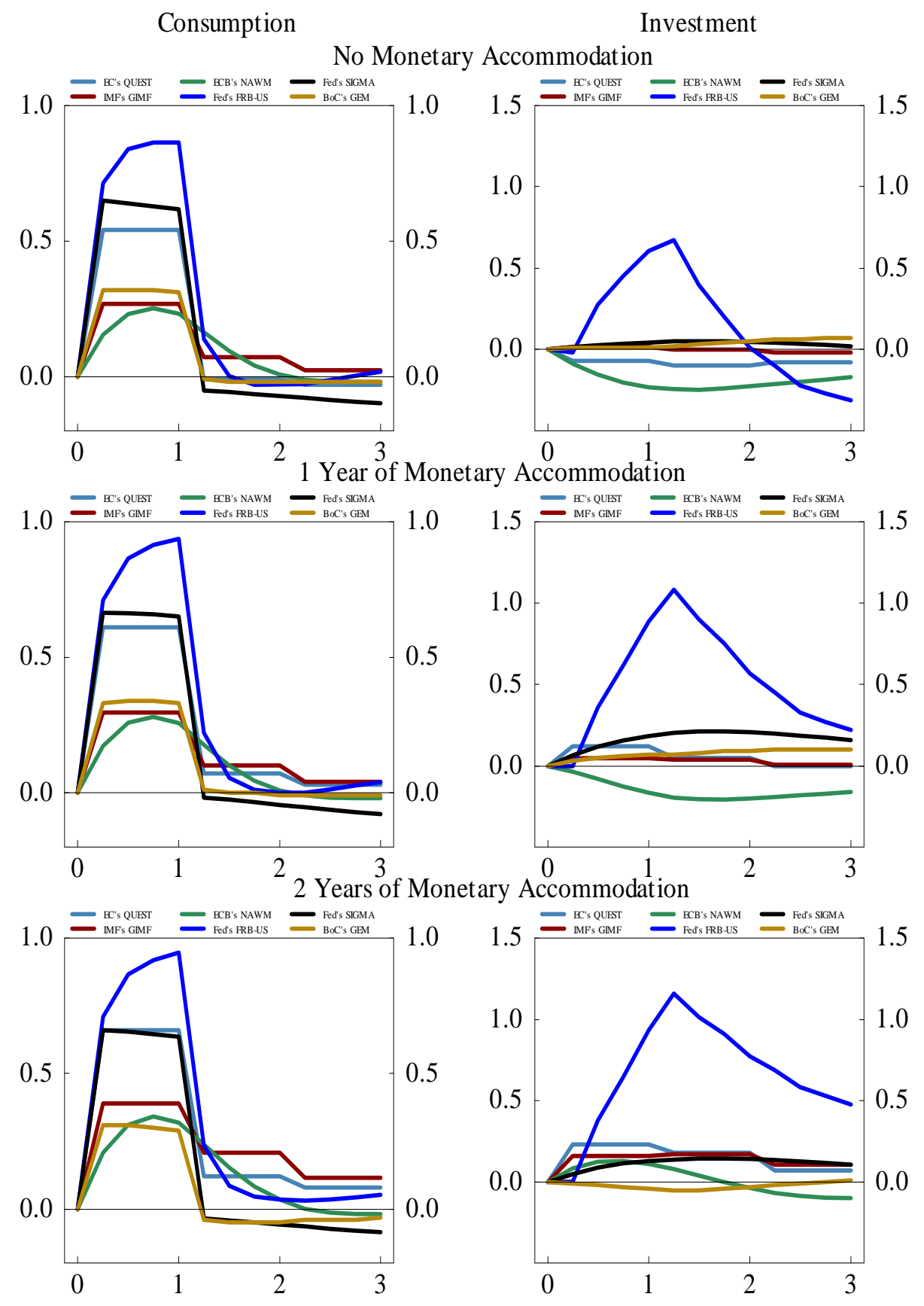


Figure 10. United States: Effect of 1 Year of Fiscal Stimulus on Real GDP (Instrument: Targeted Transfers)

(In percent)
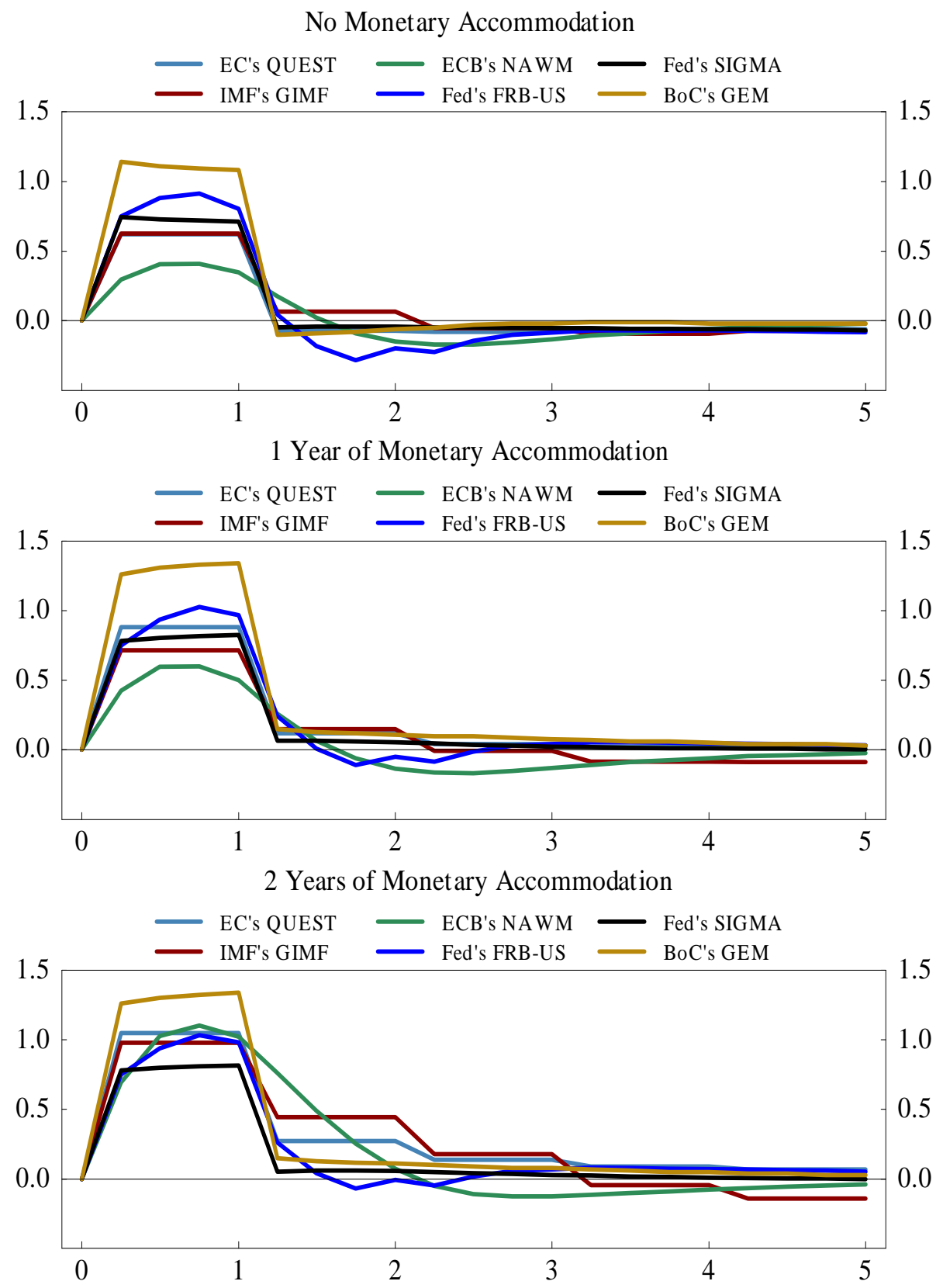
Figure 11. United States: Effect of 1 Year of Fiscal Stimulus on Inflation and the Real Interest Rate (Instrument: Targeted Transfers)

(In percentage points)

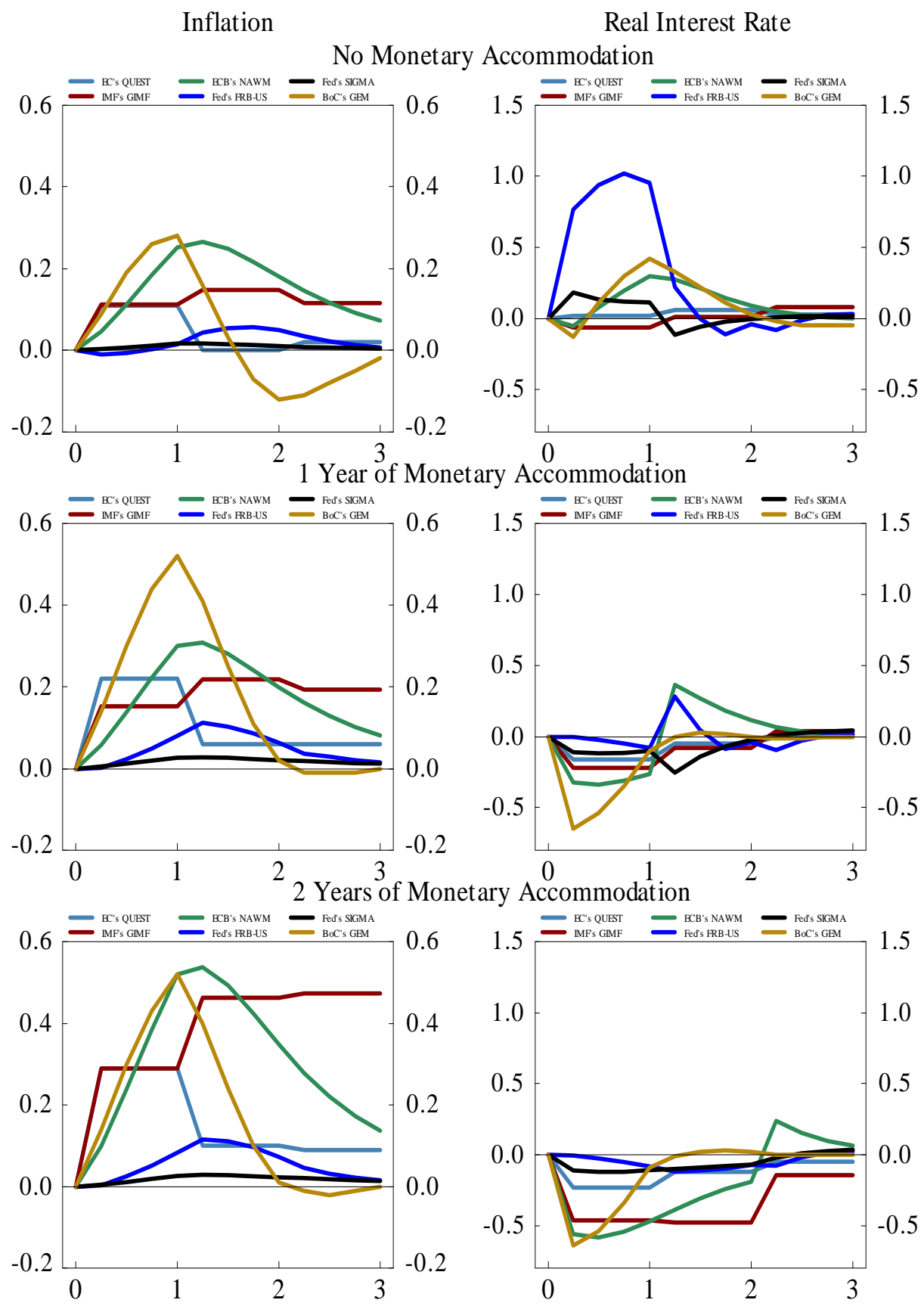


Figure 12. United States: Effect of 1 Year of Fiscal Stimulus on Consumption and Investment (Instrument: Targeted Transfers)

(In percent)
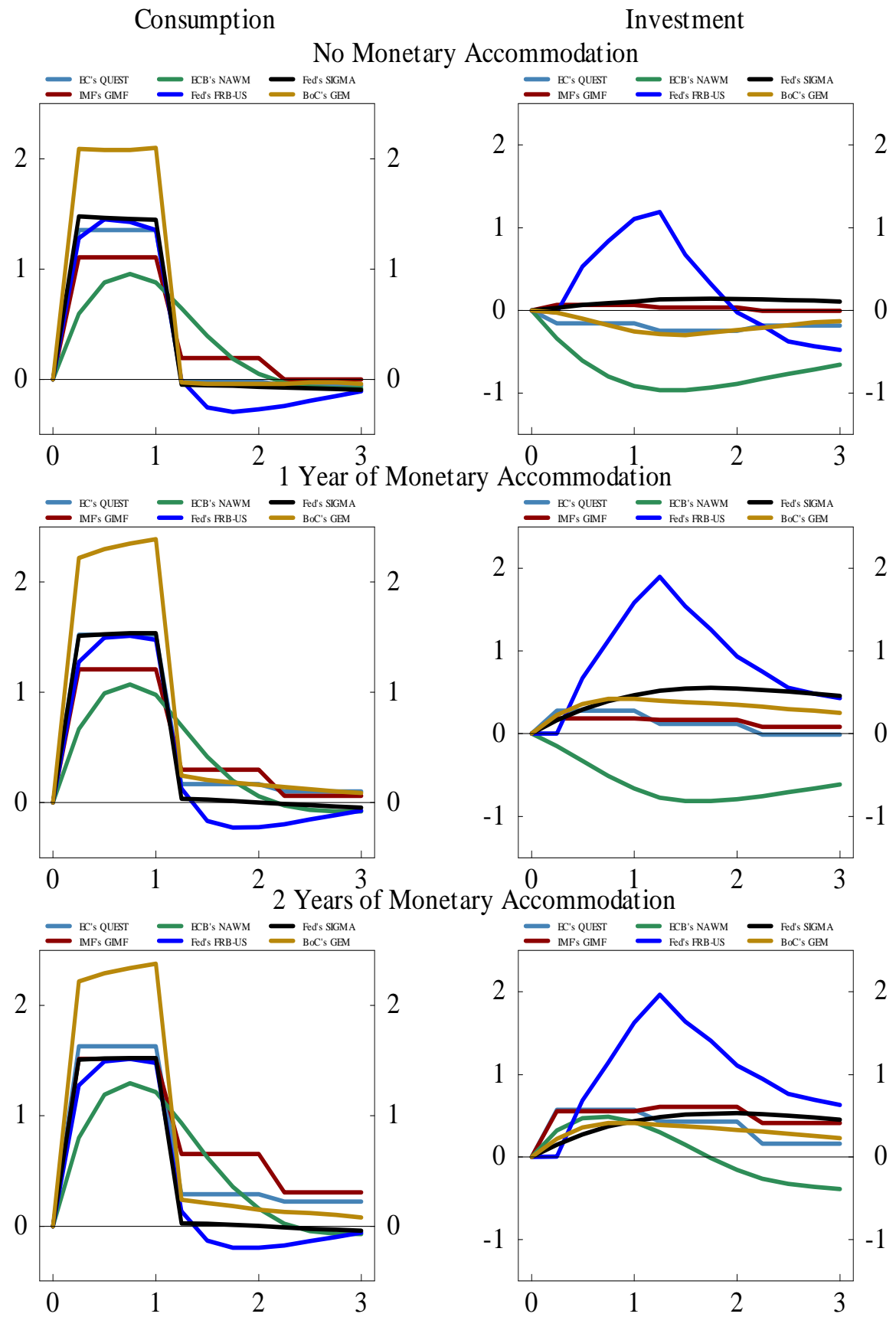
Figure 13. United States: Effect of 1 Year of Fiscal Stimulus on Real GDP (Instrument: Labor Income Tax)

$$
\text { (In percent) }
$$
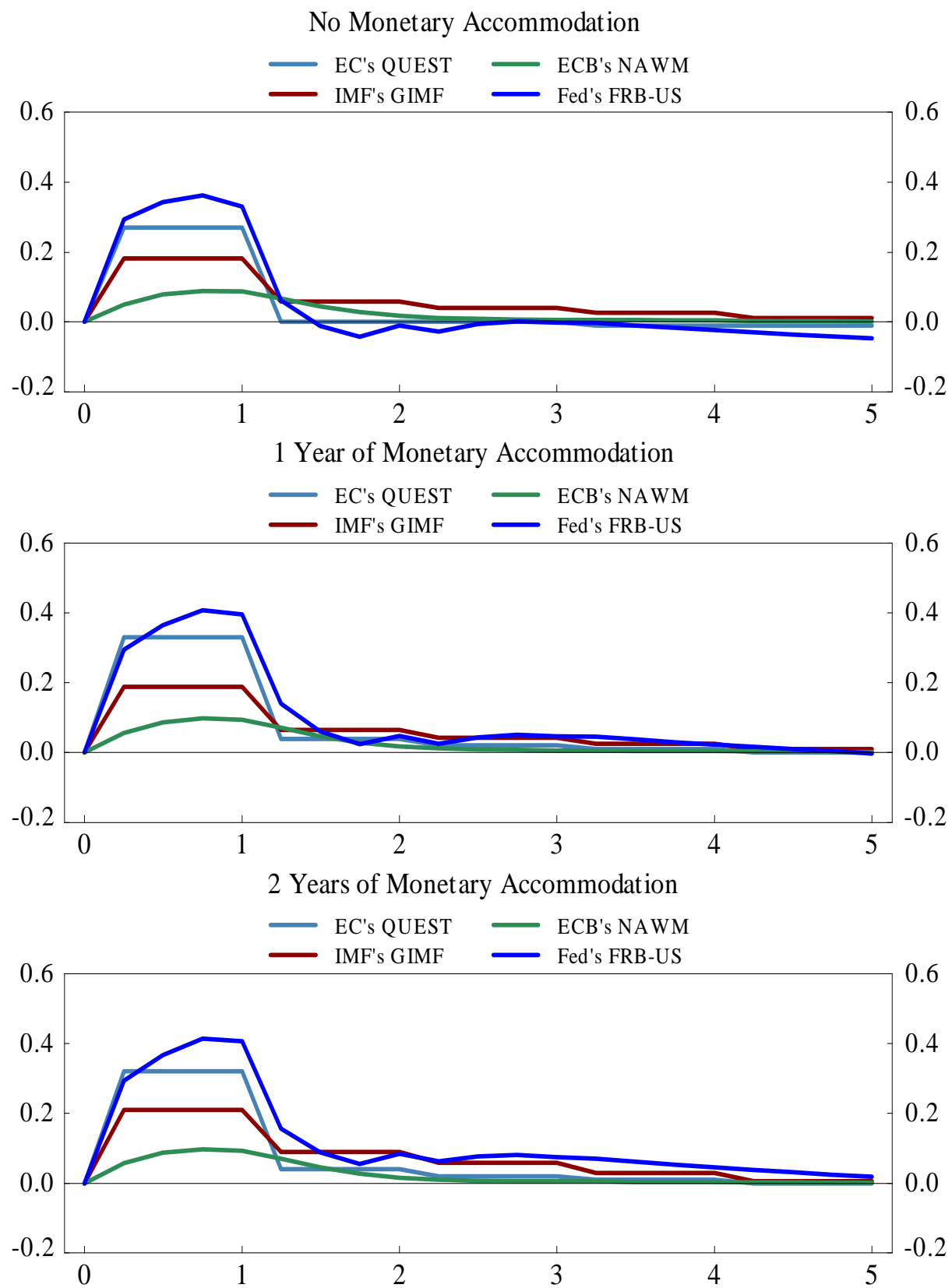
Figure 14. United States: Effect of 1 Year of Fiscal Stimulus on Inflation and the Real Interest Rate (Instrument: Labor Income Tax)

(In percentage points)

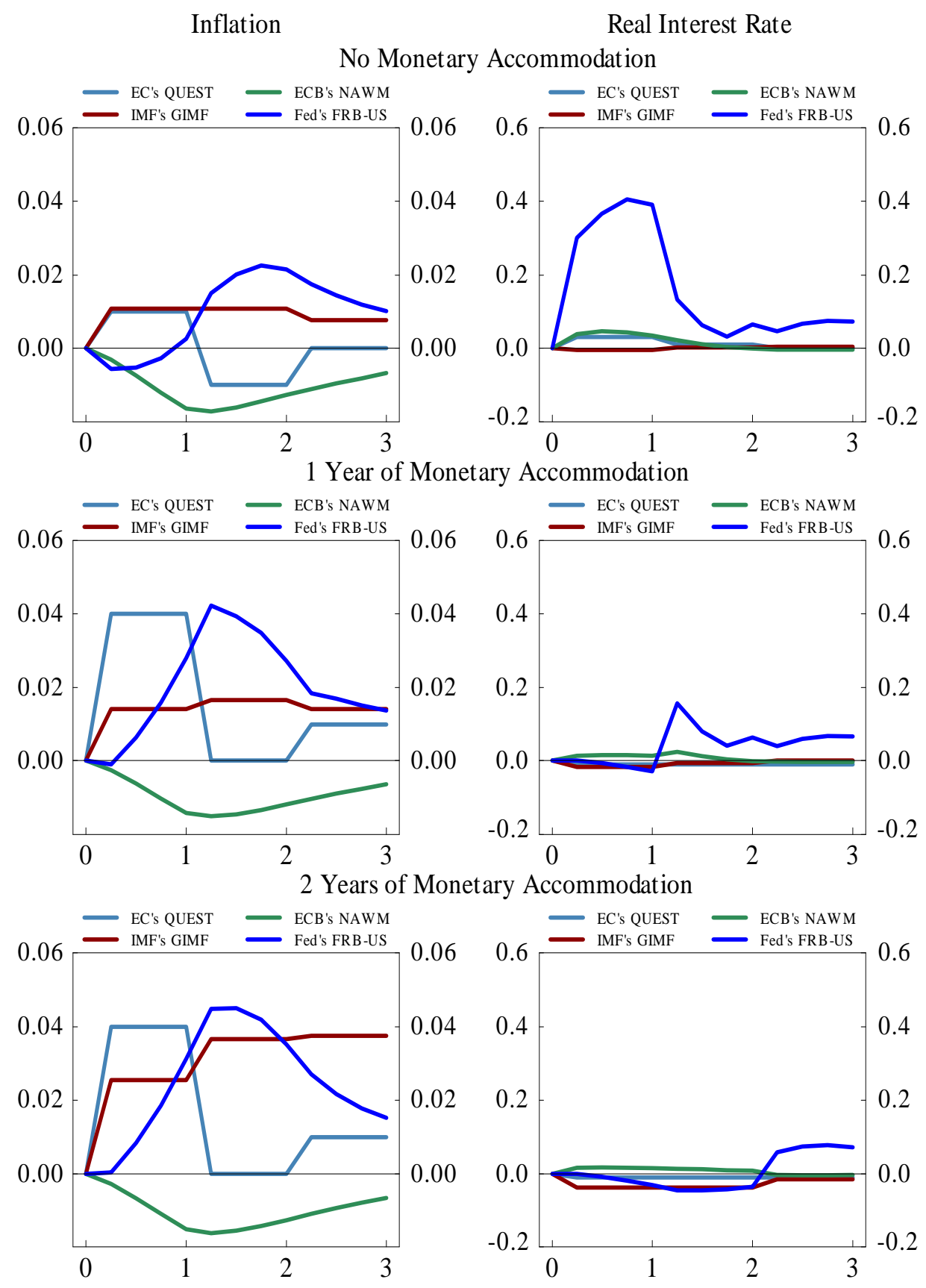


Figure 15. United States: Effect of 1 Year of Fiscal Stimulus on Consumption and Investment (Instrument: Labor Income Tax)

$$
\text { (In percent) }
$$

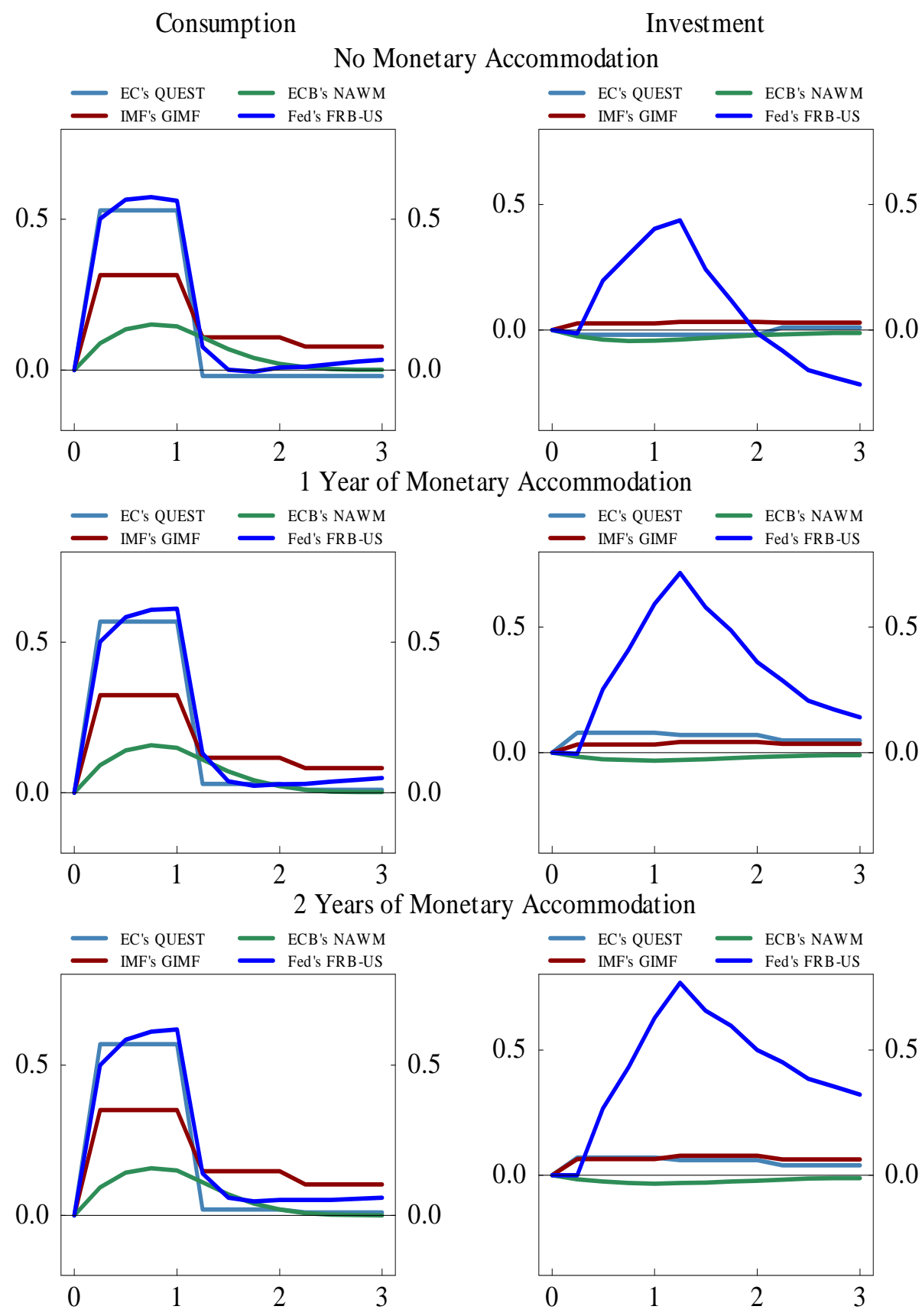


Figure 16. United States: Effect of 1 Year of Fiscal Stimulus on Real GDP (Instrument: Consumption Tax)

$$
\text { (In percent) }
$$

No Monetary Accommodation
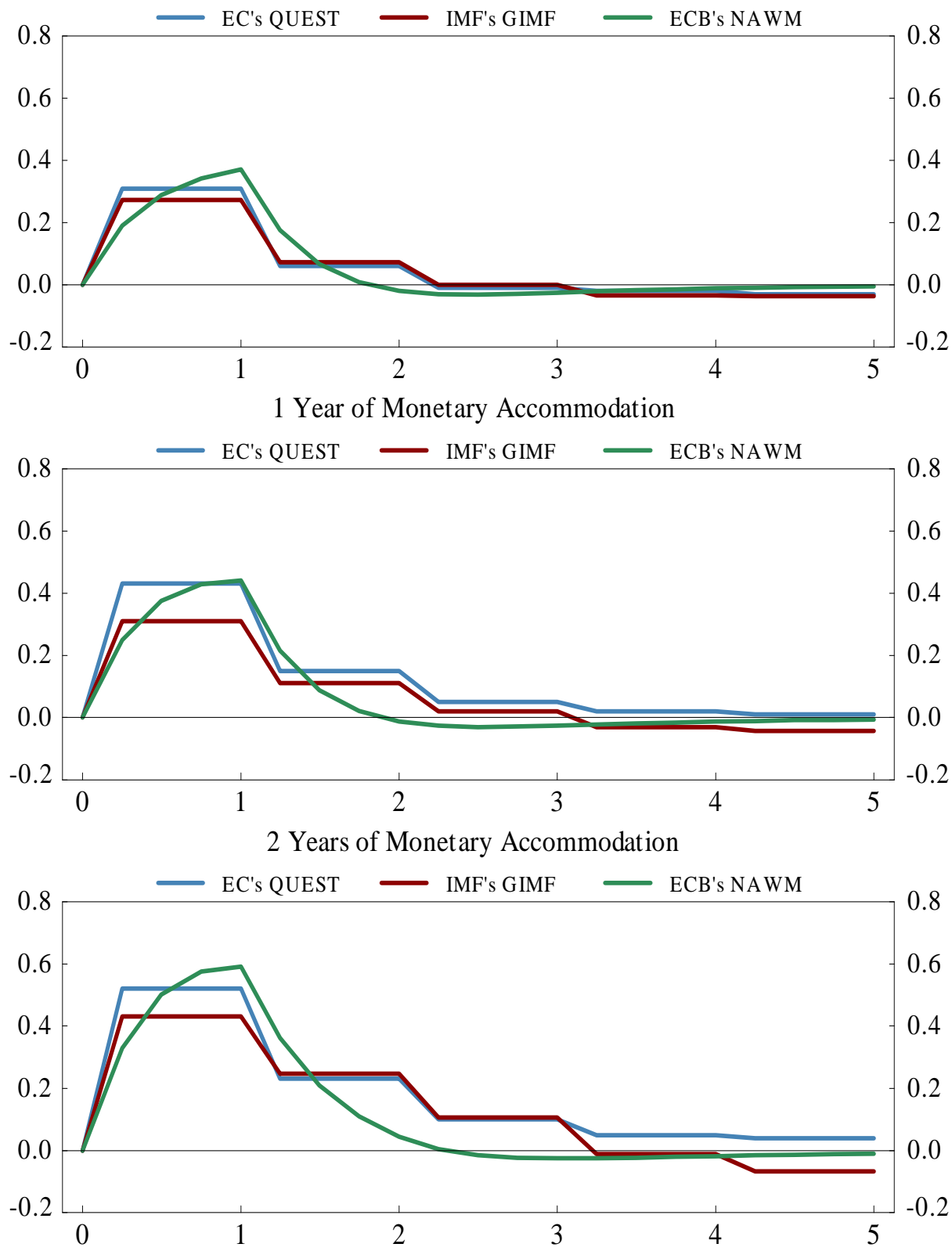
Figure 17. United States: Effect of 1 Year of Fiscal Stimulus on Inflation and the Real Interest Rate (Instrument: Consumption Tax)

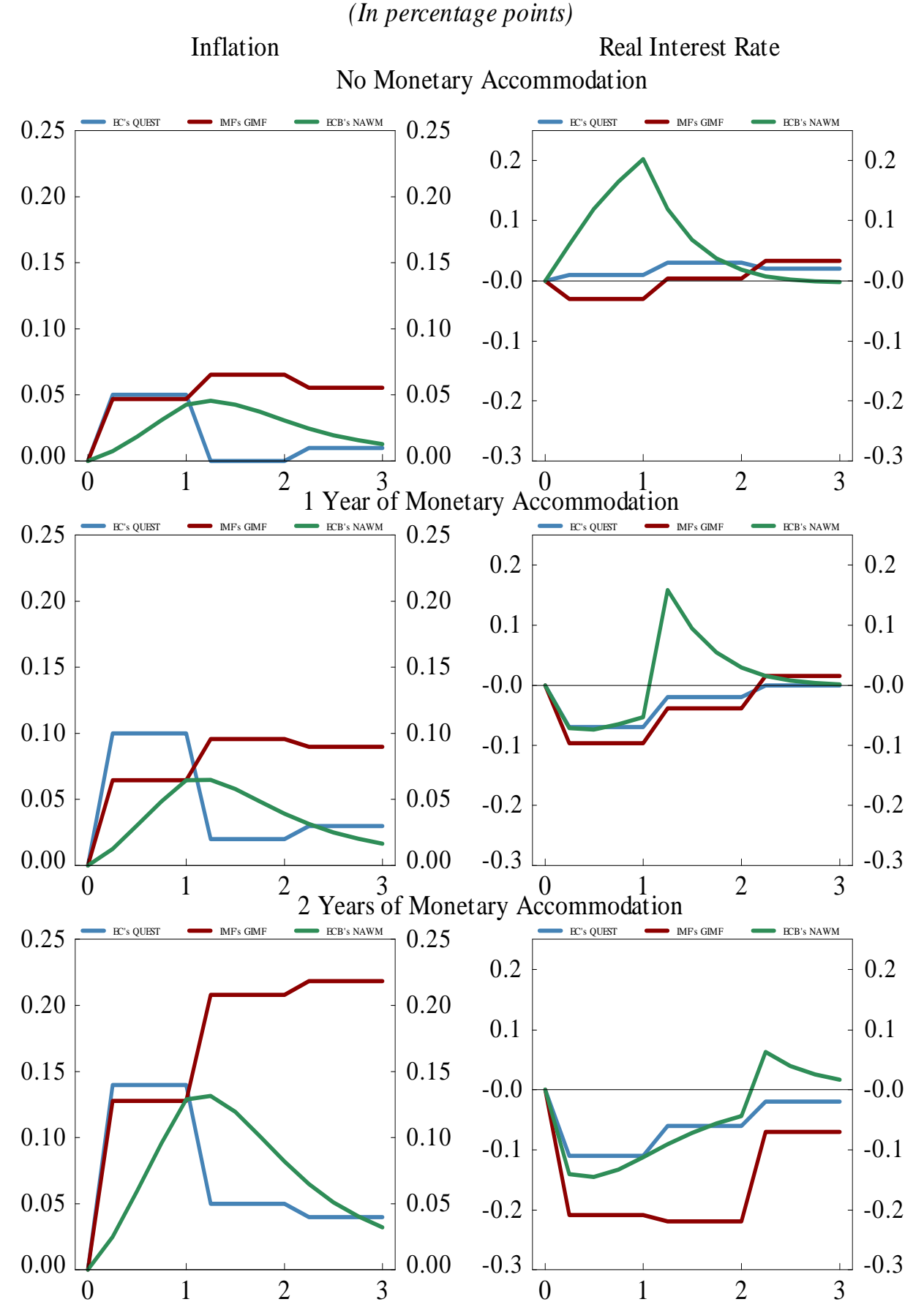


Figure 18. United States: Effect of 1 Year of Fiscal Stimulus on Consumption and Investment (Instrument: Consumption Tax)

$$
\text { (In percent) }
$$

Consumption Investment

No Monetary Accommodation
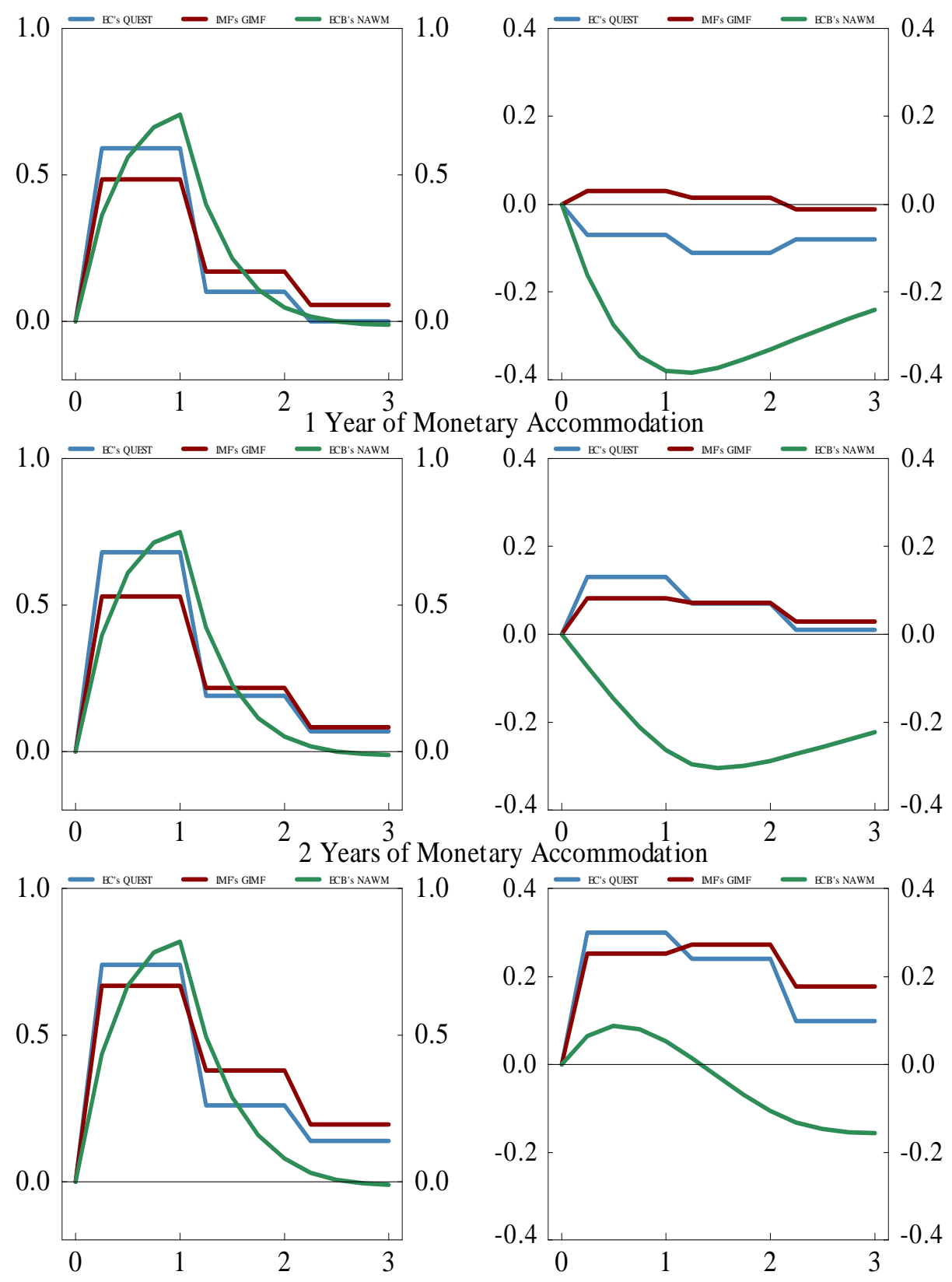
Figure 19. United States: Effect of 1 Year of Fiscal Stimulus on Real GDP (Instrument: Corporate Income Tax)

$$
\text { (In percent) }
$$
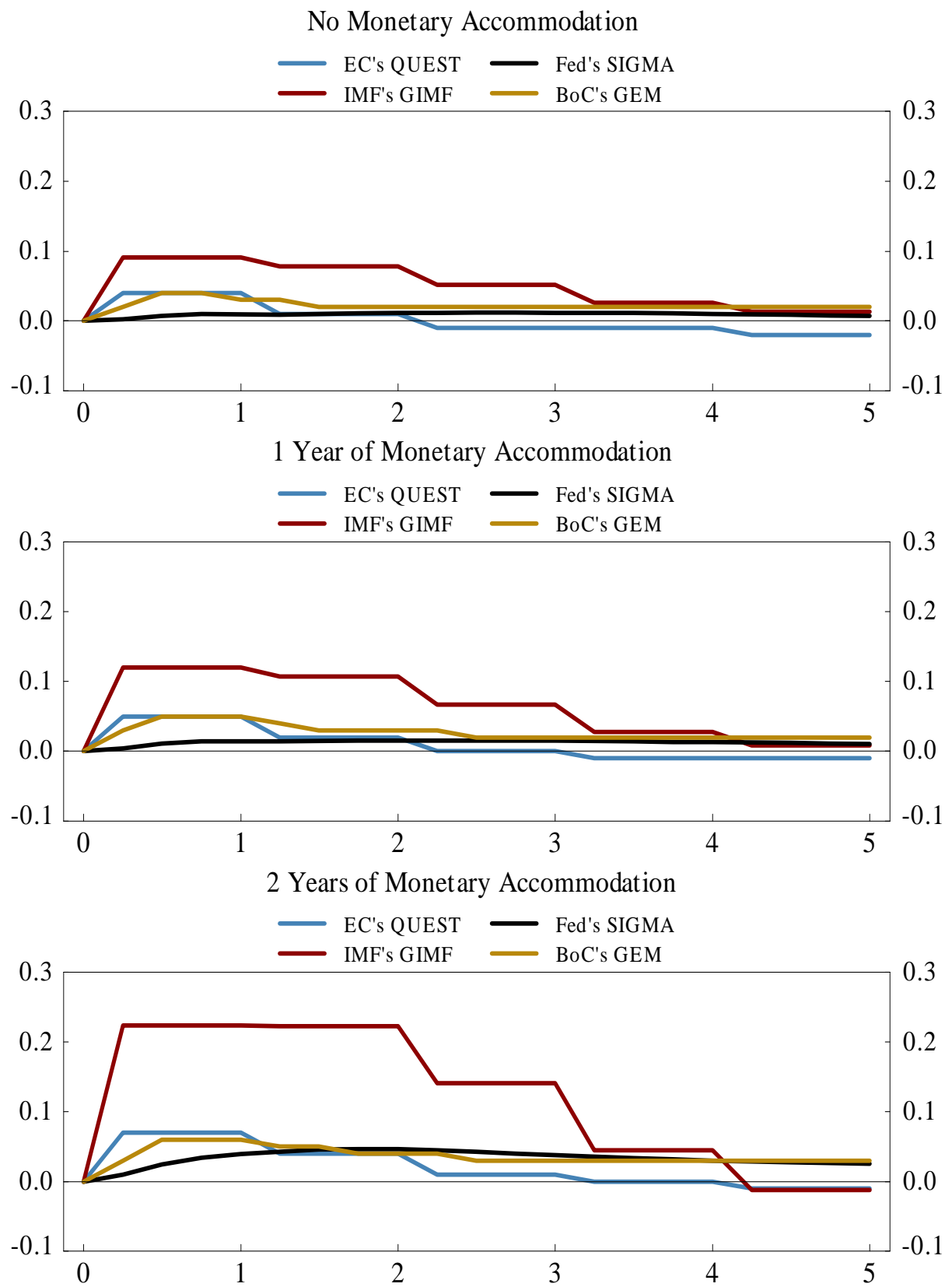
Figure 20. United States: Effect of 1 Year of Fiscal Stimulus on Inflation and the Real Interest Rate (Instrument: Corporate Income Tax)

(In percentage points)

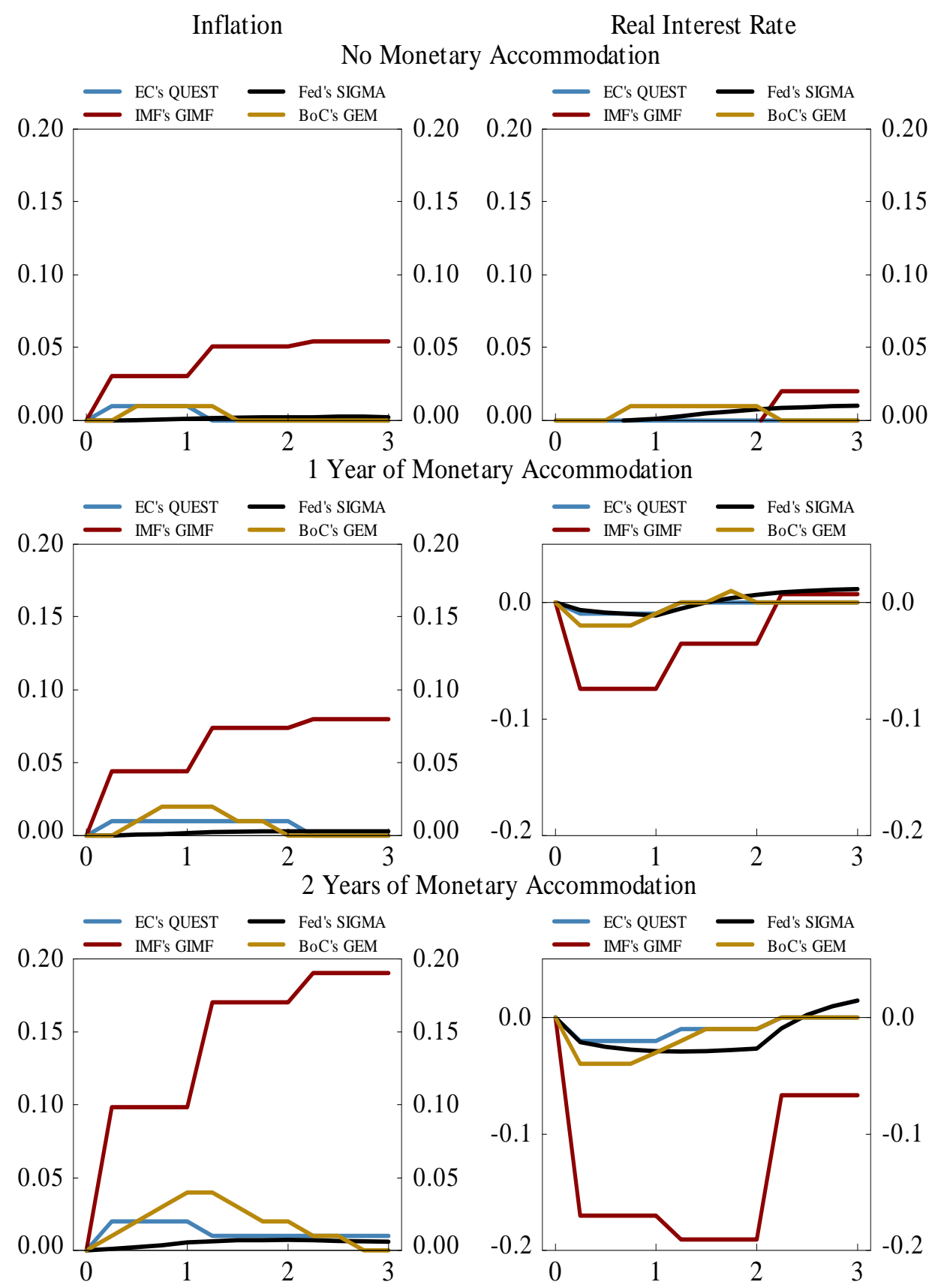


Figure 21. United States: Effect of 1 Year of Fiscal Stimulus on Consumption and Investment (Instrument: Corporate Income Tax)

(In percent)

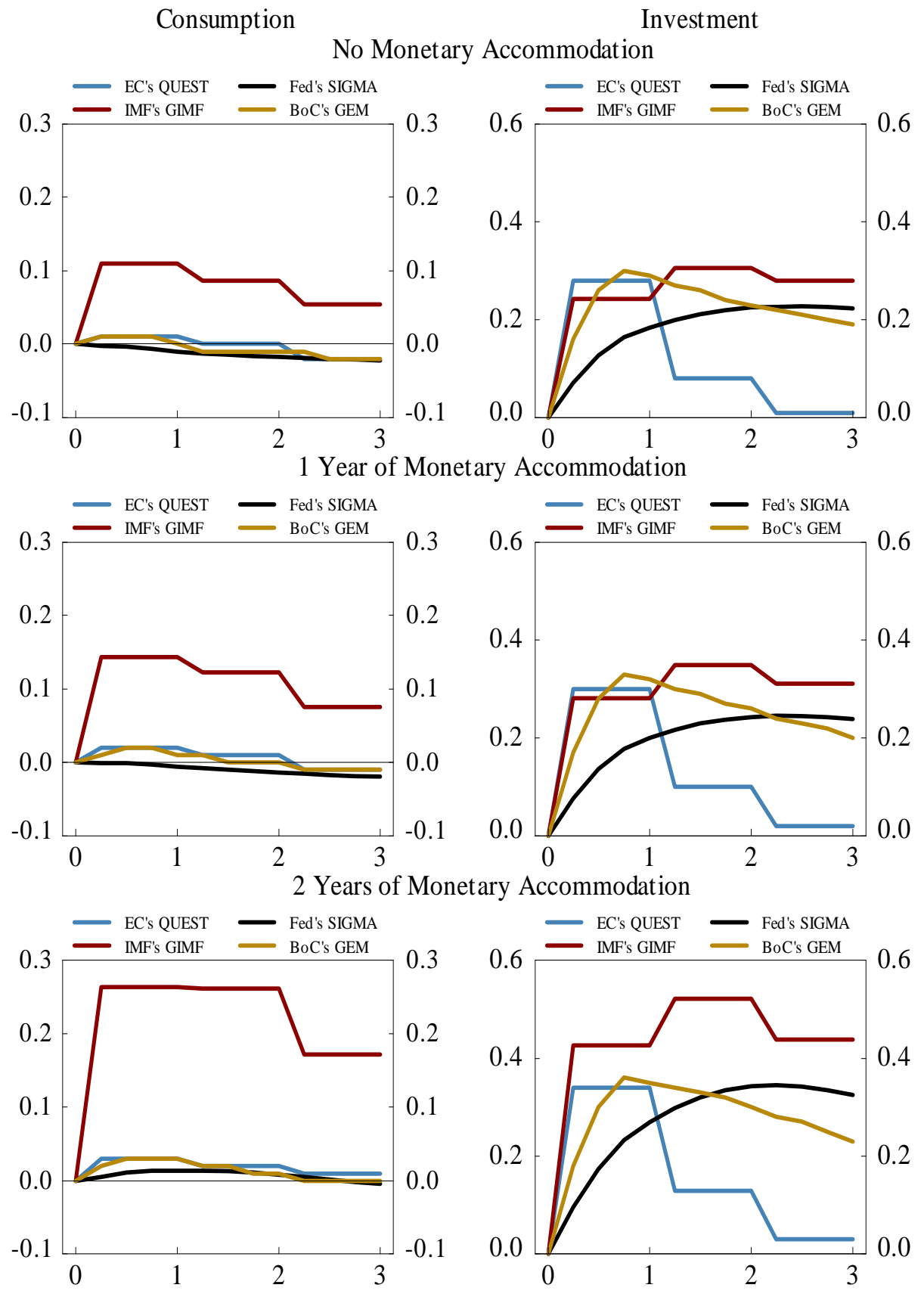


Figure 22. United States: Effect of 2 Years of Fiscal Stimulus on Real GDP (Instrument: Government Investment)

$$
\text { (In percent) }
$$
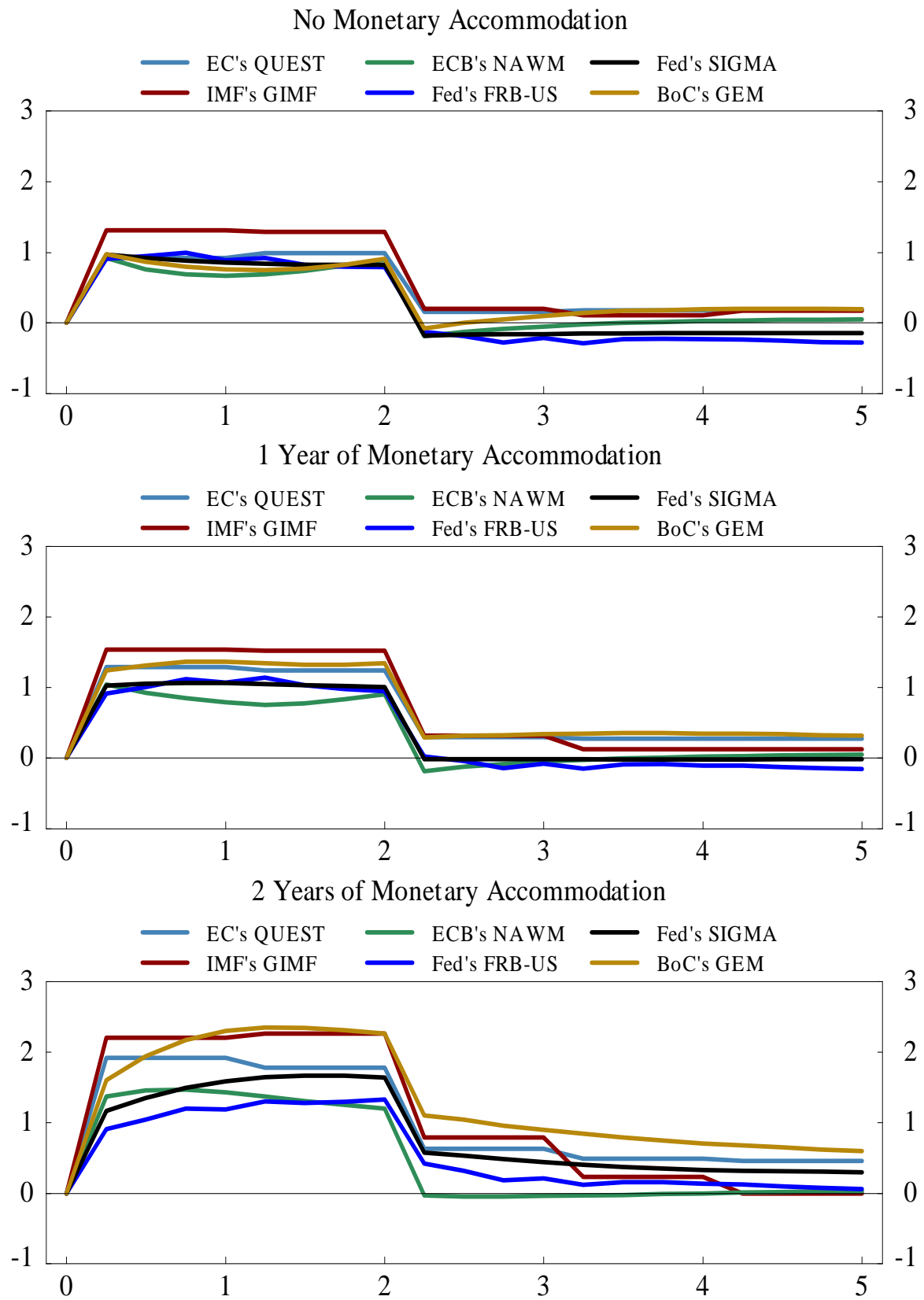
Figure 23. United States: Effect of 2 Years of Fiscal Stimulus on Inflation and the Real Interest Rate (Instrument: Government Investment)

(In percentage points)

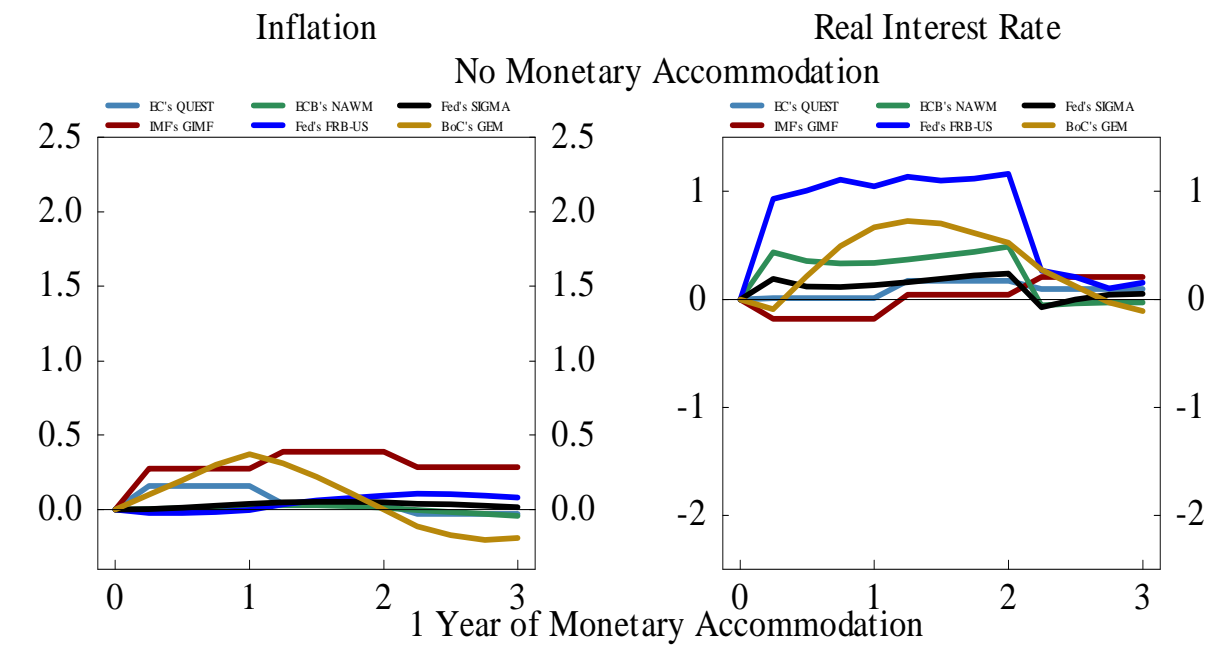

Real Interest Rate
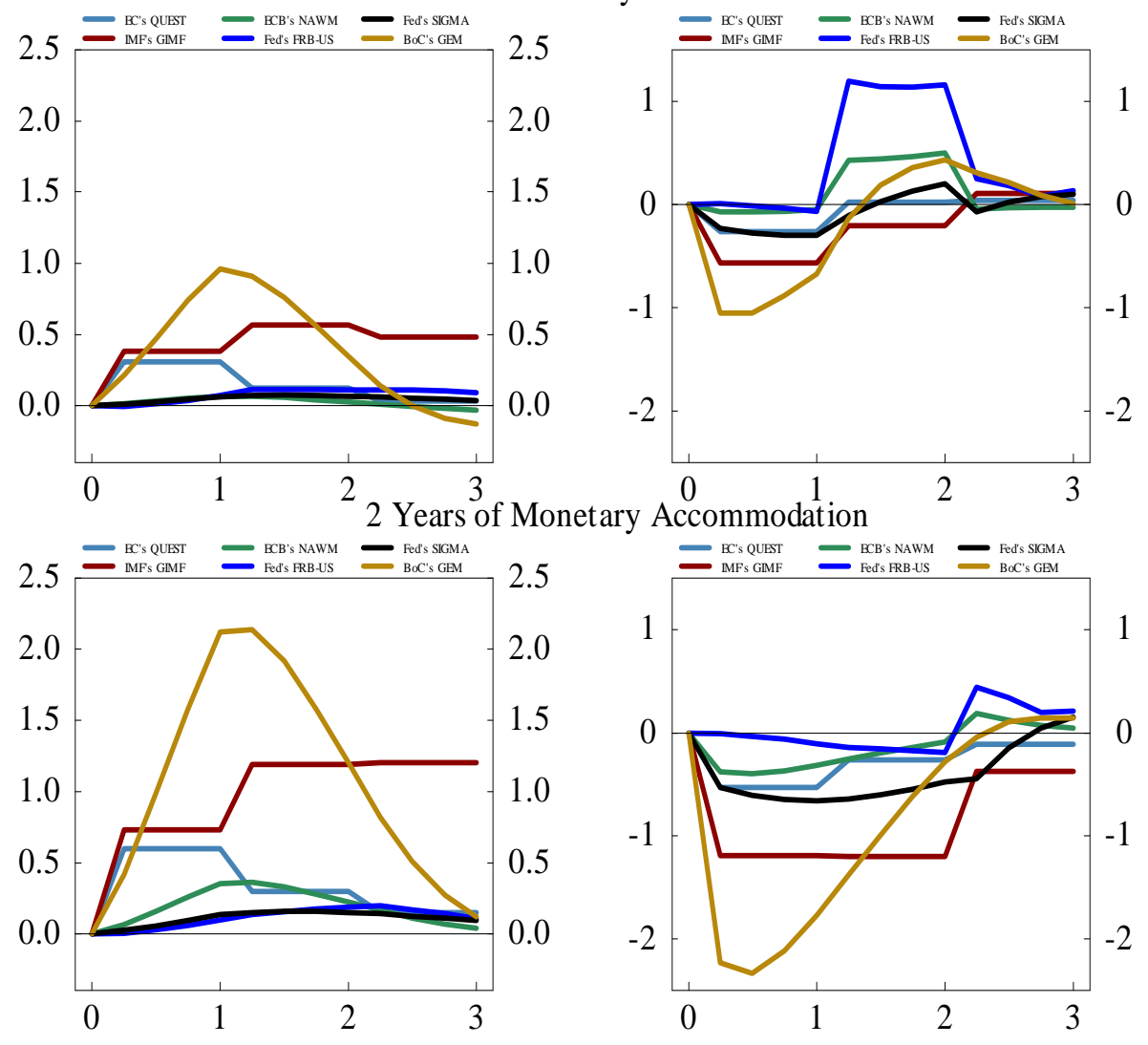
Figure 24. United States: Effect of 2 Years of Fiscal Stimulus on Consumption and Investment (Instrument: Government Investment)

(In percent)

Consumption Investment

No Monetary Accommodation
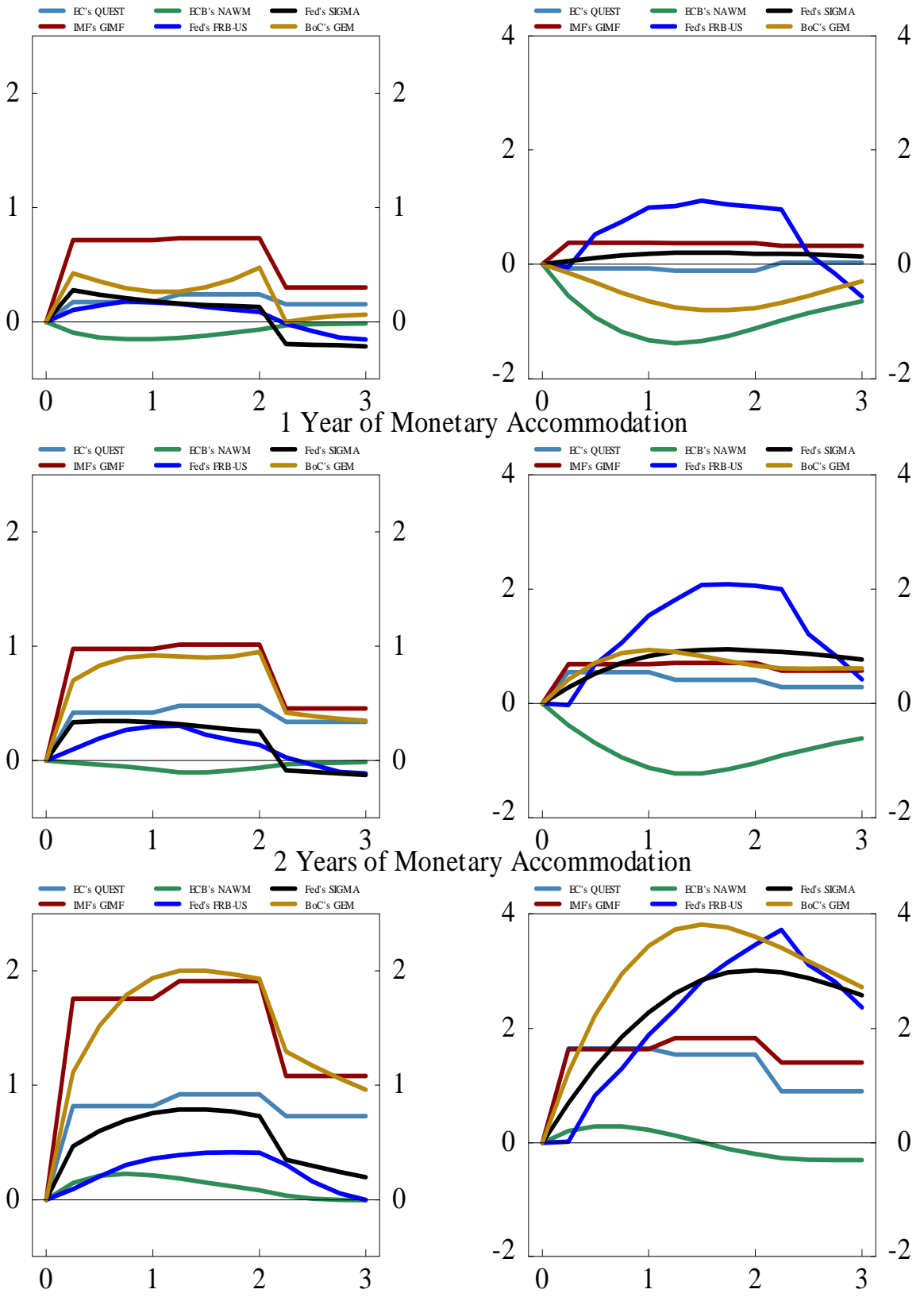
Figure 25. United States: Effect of 2 Years of Fiscal Stimulus on Real GDP (Instrument: Government Consumption)

(In percent)
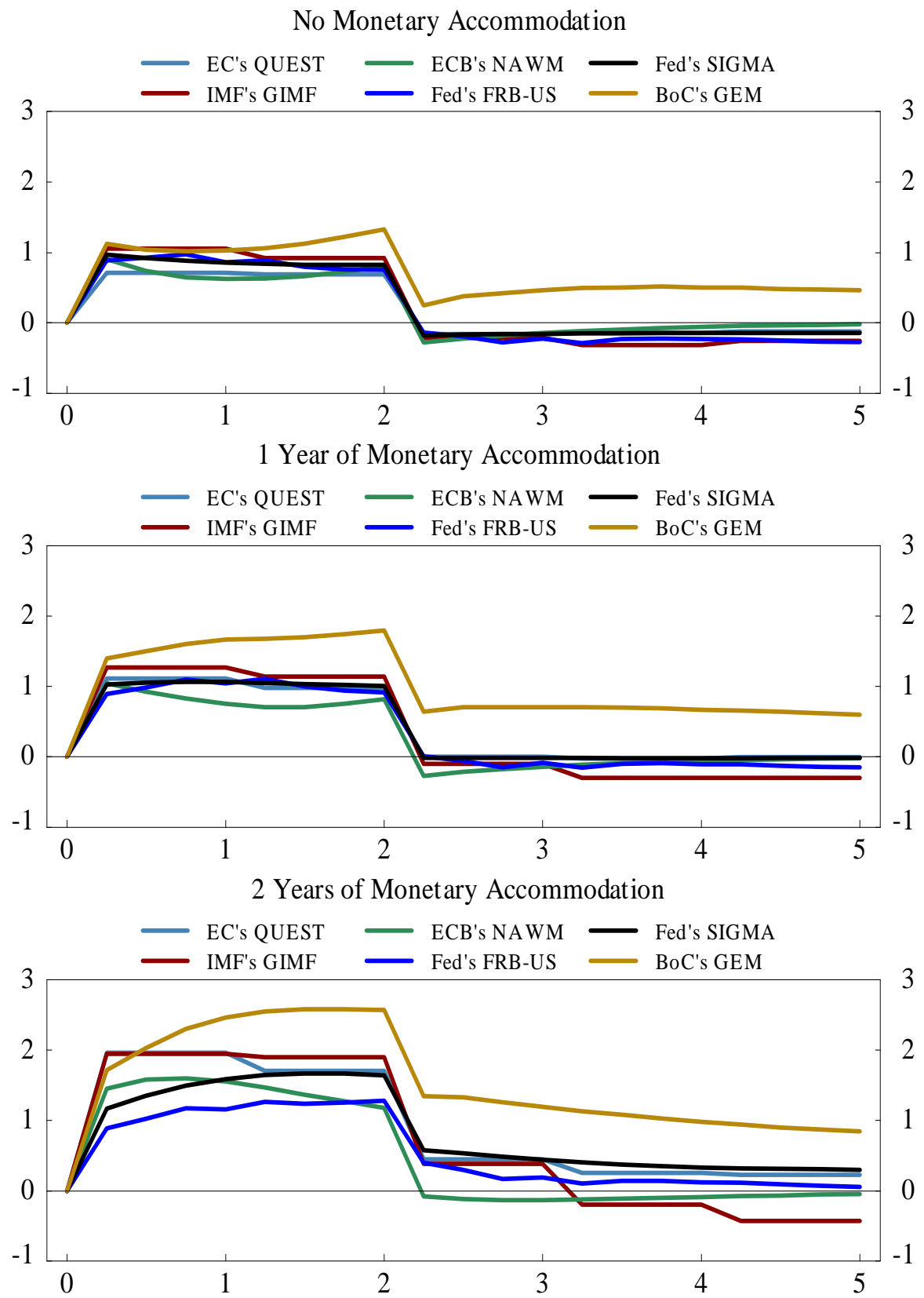
Figure 26. United States: Effect of 2 Years of Fiscal Stimulus on Inflation and the Real Interest Rate (Instrument: Government Consumption)

(In percentage points)
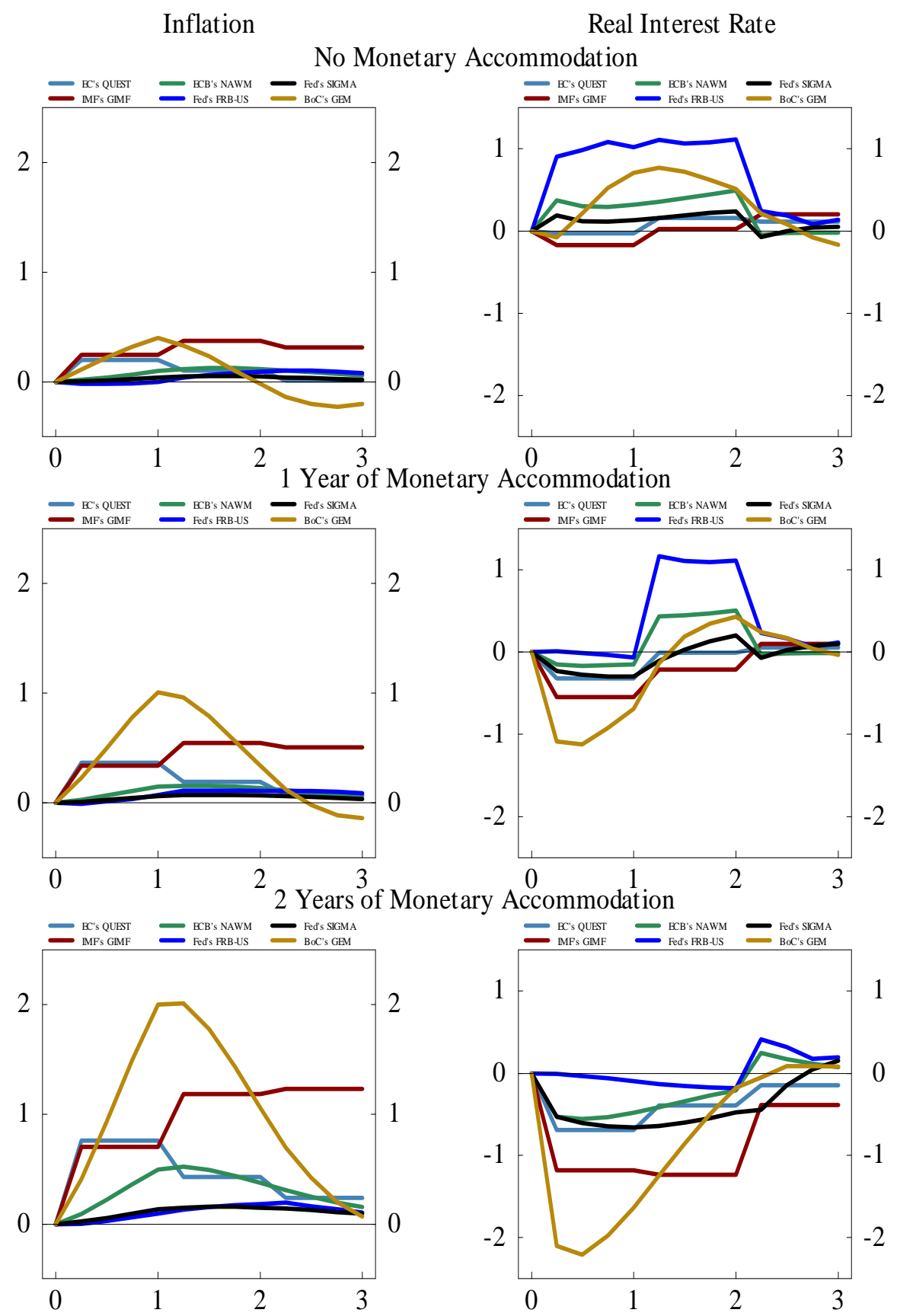
Figure 27. United States: Effect of 2 Years of Fiscal Stimulus on Consumption and Investment (Instrument: Government Consumption)

\section{(In percent)}

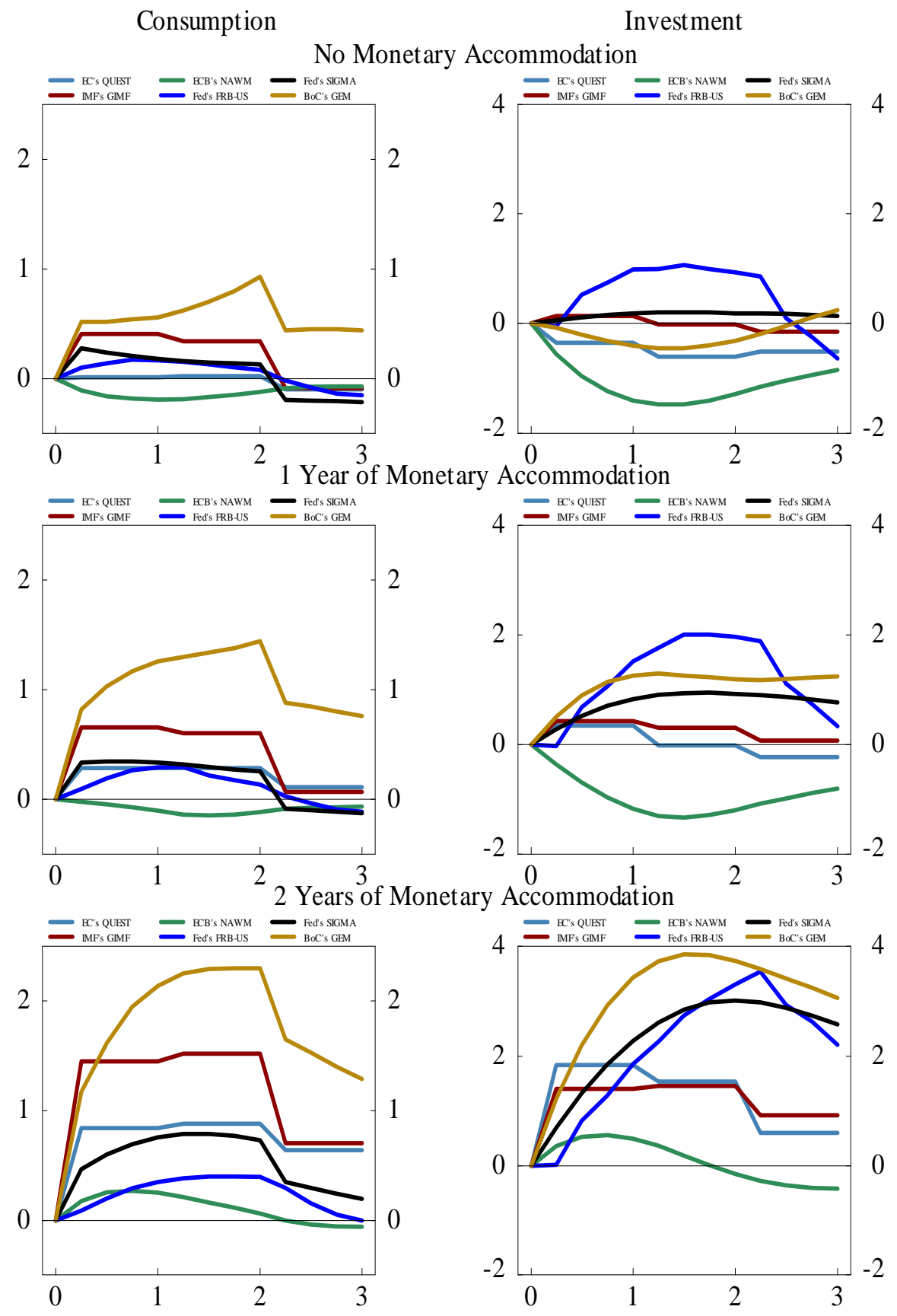


Figure 28. United States: Effect of 2 Years of Fiscal Stimulus on Real GDP (Instrument: General Transfers)

$$
\text { (In percent) }
$$
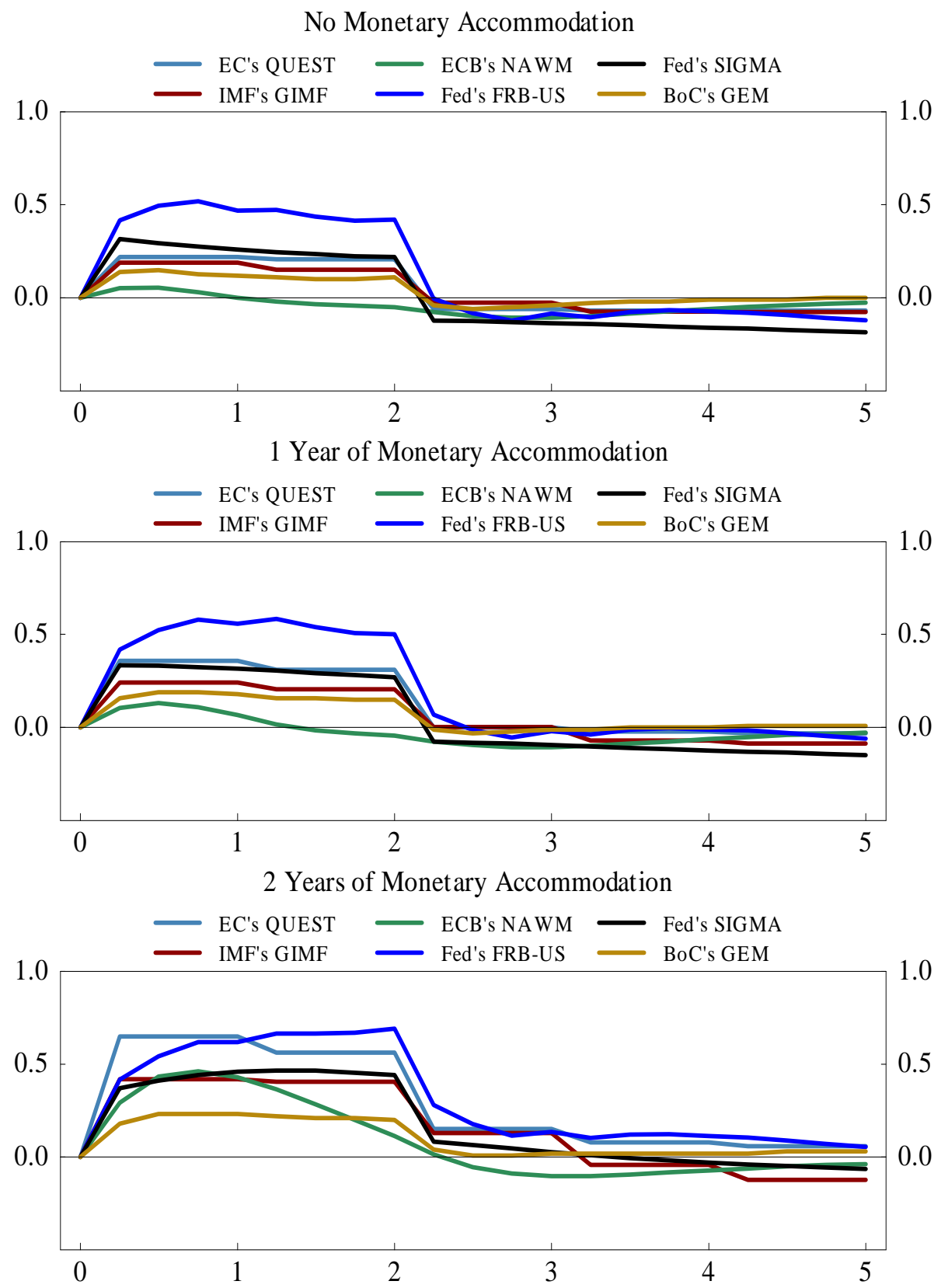
Figure 29. United States: Effect of 2 Years of Fiscal Stimulus on Inflation and the Real Interest Rate (Instrument: General Transfers)

(In percentage points)
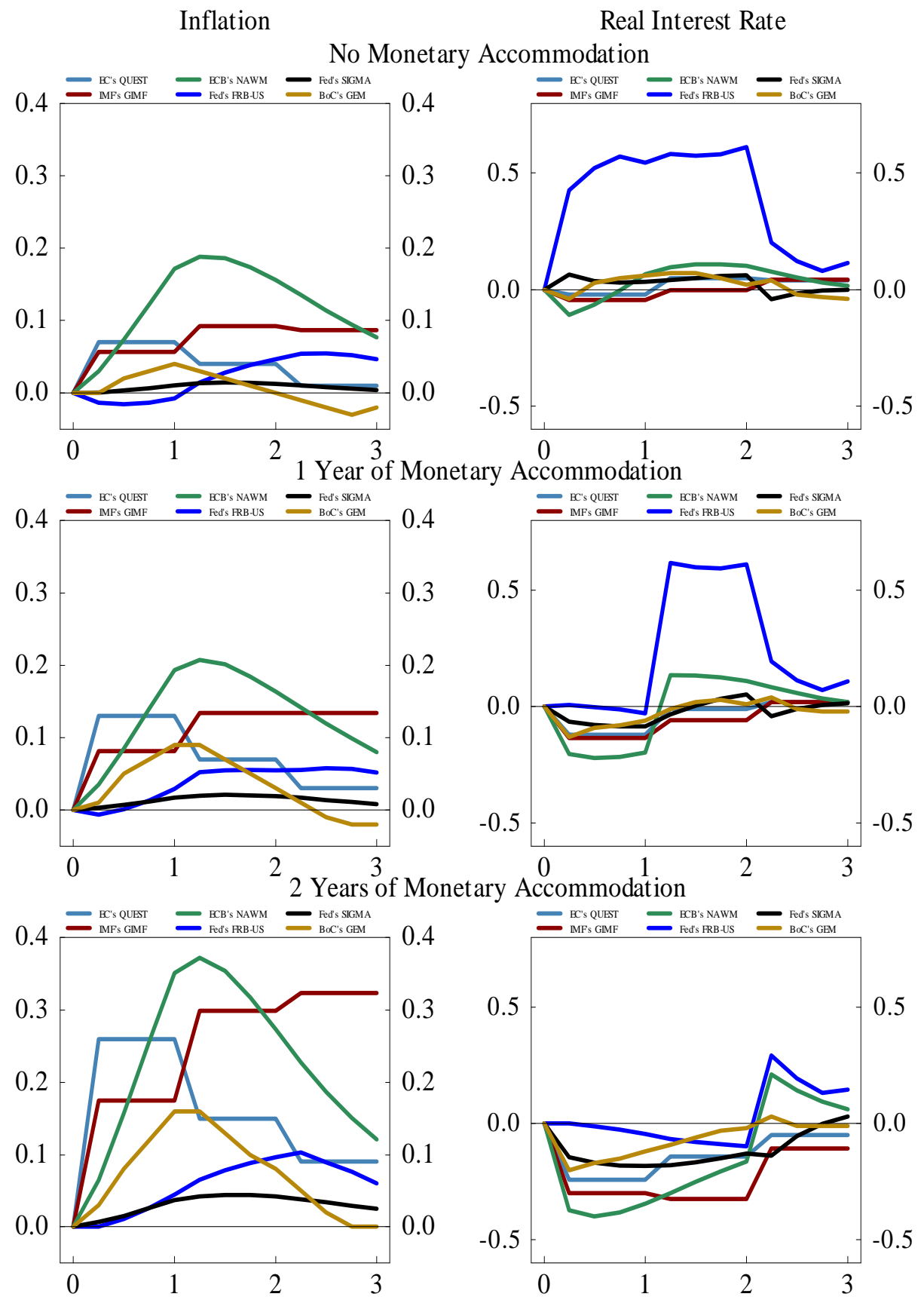
Figure 30. United States: Effect of 2 Years of Fiscal Stimulus on Consumption and Investment (Instrument: General Transfers)

(In percent)

Consumption

Investment

No Monetary Accommodation
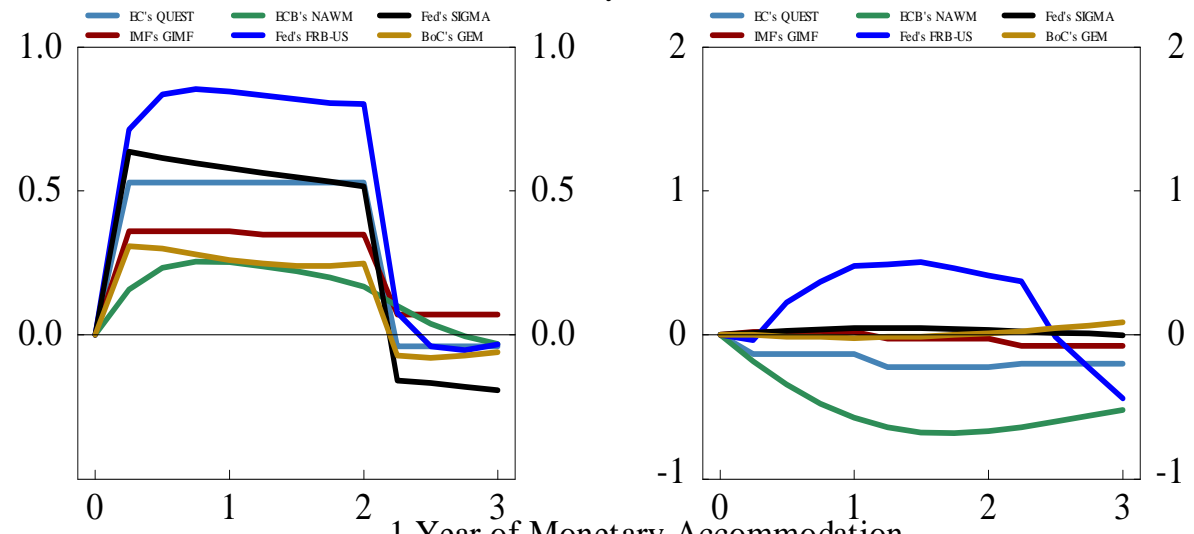

1 Year of Monetary Accommodation
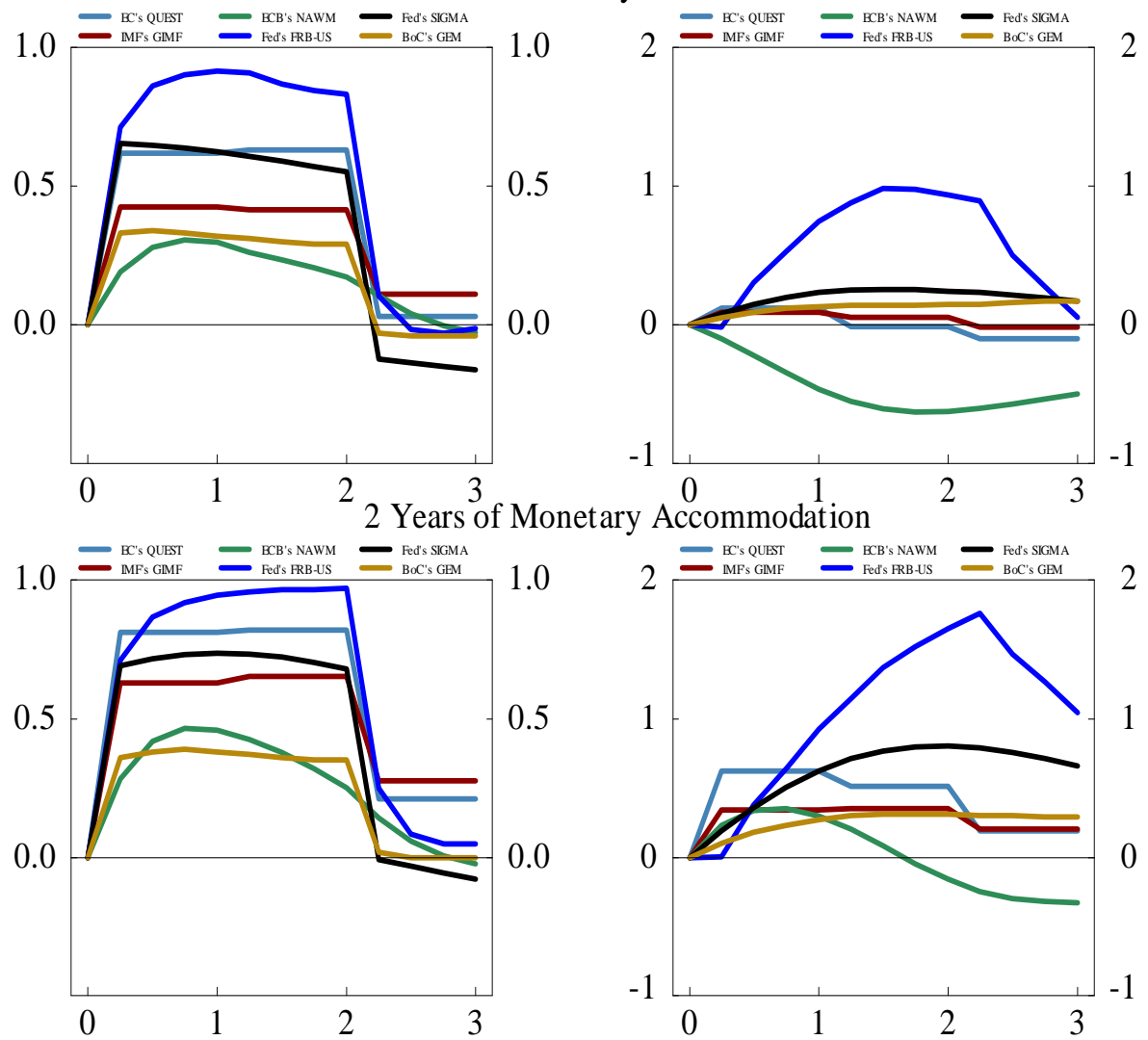
Figure 31. United States: Effect of 2 Years of Fiscal Stimulus on Real GDP (Instrument: Targeted Transfers)

$$
\text { (In percent) }
$$
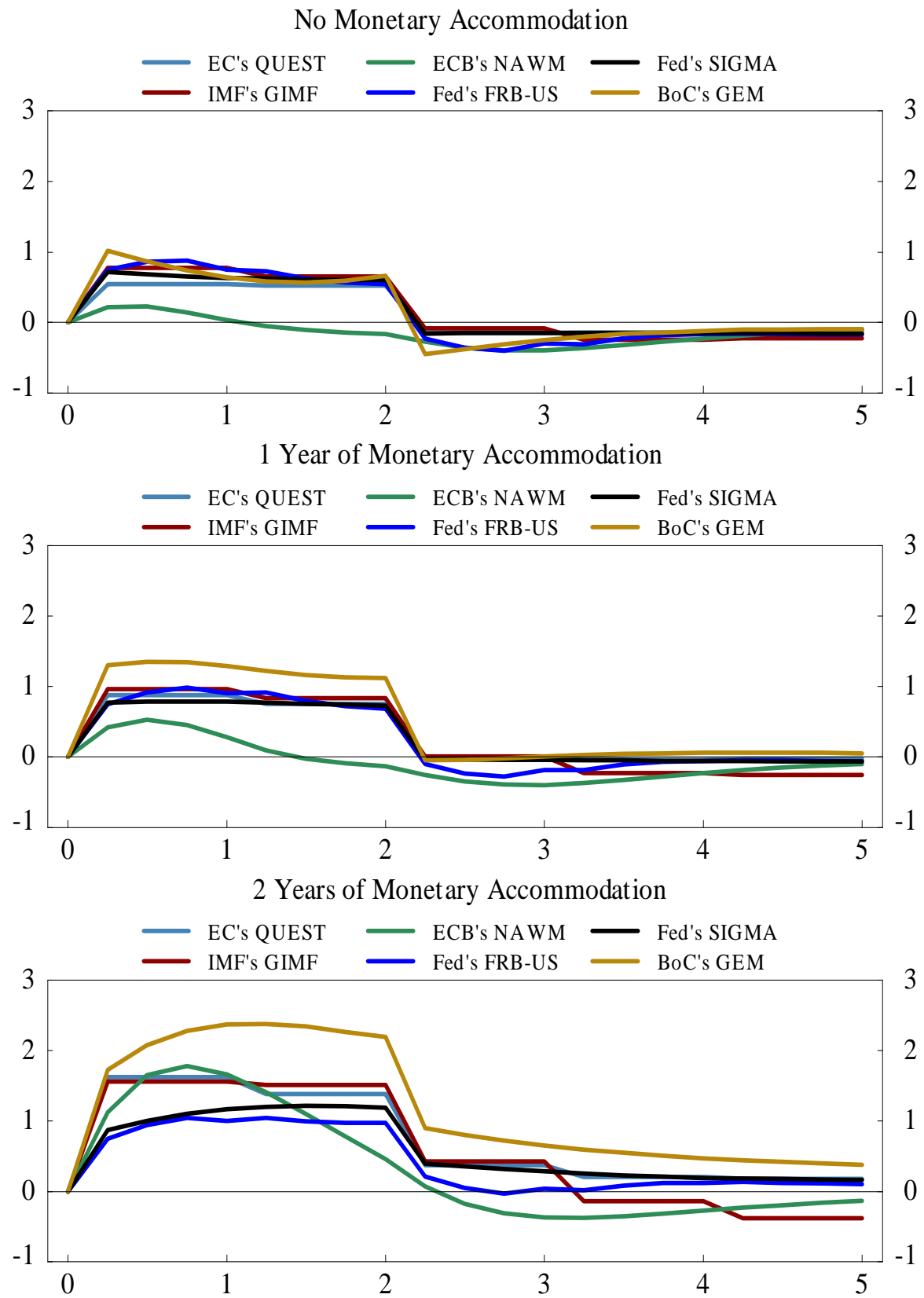
Figure 32. United States: Effect of 2 Years of Fiscal Stimulus on Inflation and the Real Interest Rate (Instrument: Targeted Transfers)

(In percentage points)

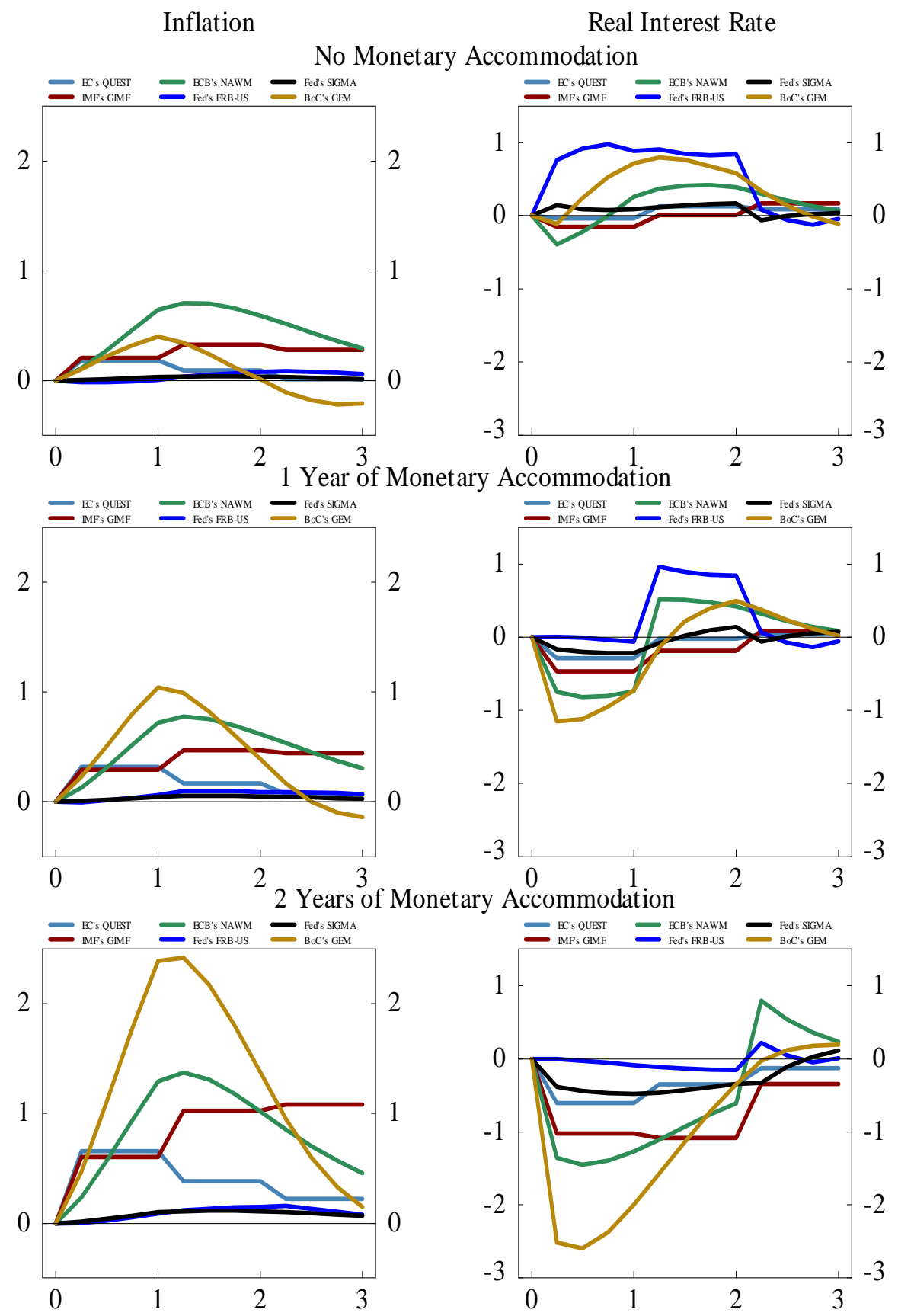


Figure 33. United States: Effect of 2 Years of Fiscal Stimulus on Consumption and Investment (Instrument: Targeted Transfers)

(In percent)

Consumption Investment

No Monetary Accommodation
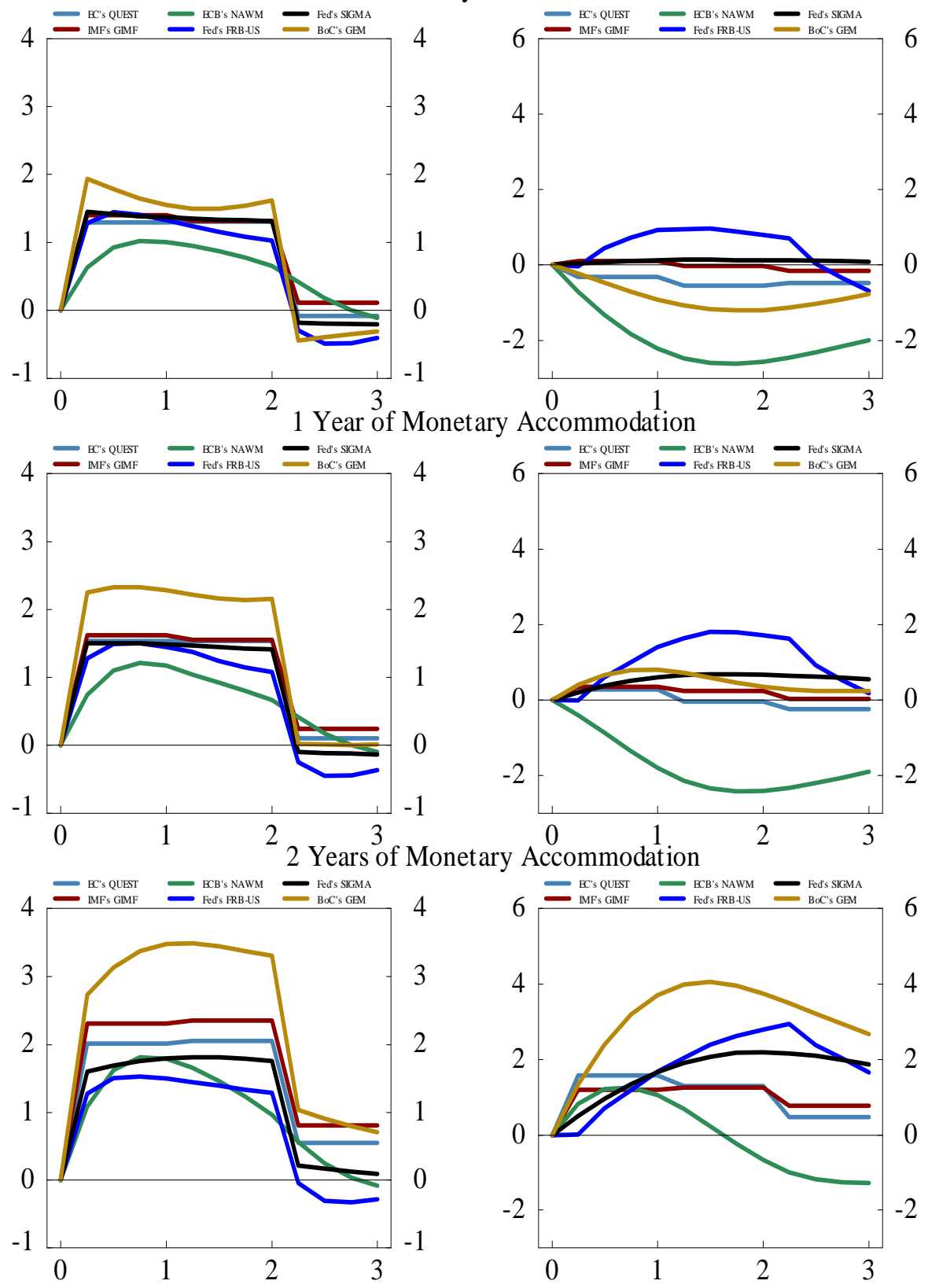
Figure 34. United States: Effect of 2 Years of Fiscal Stimulus on Real GDP (Instrument: Labor Income Tax)

$$
\text { (In percent) }
$$
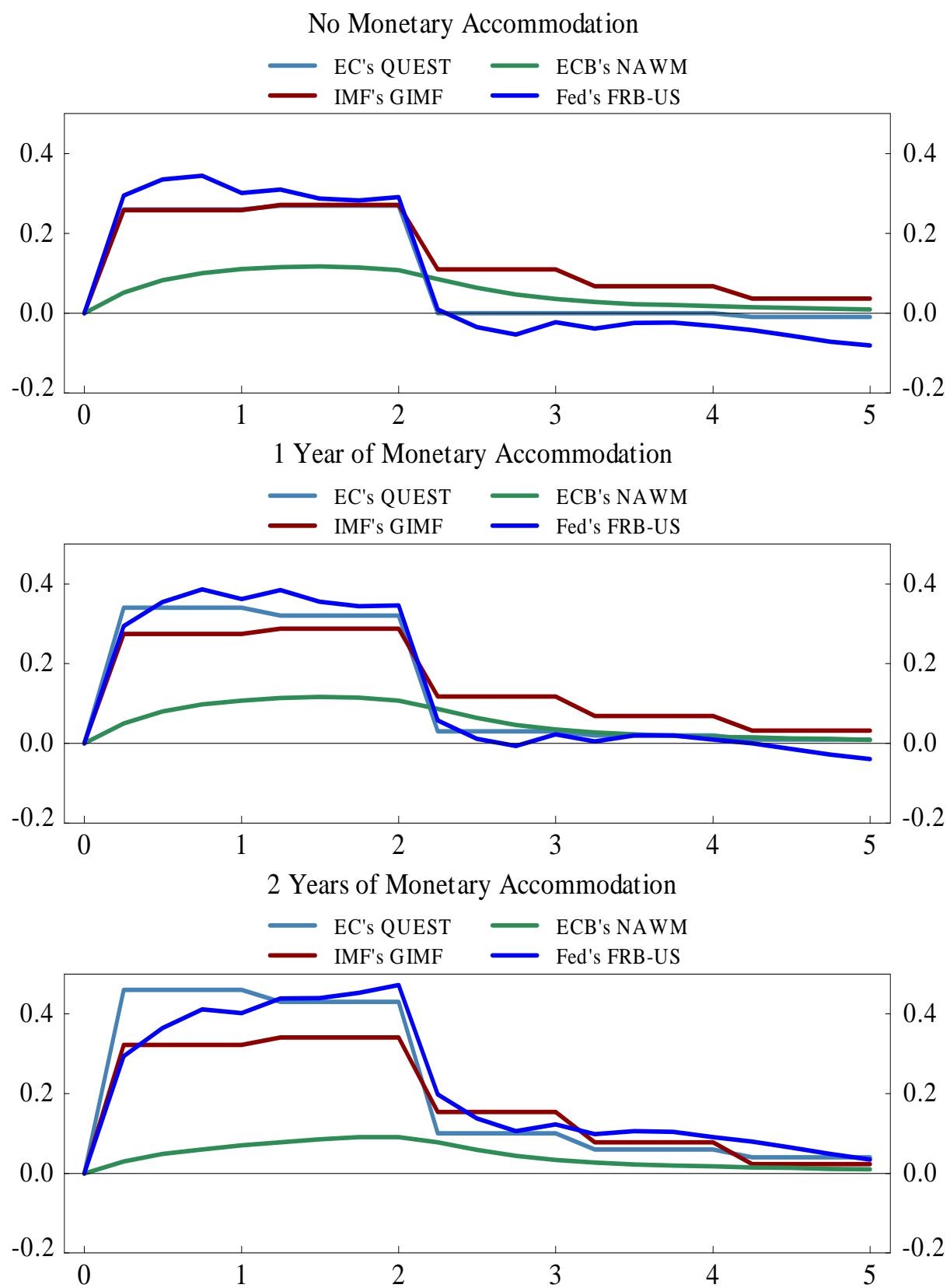
Figure 35. United States: Effect of 2 Years of Fiscal Stimulus on Inflation and the Real Interest Rate (Instrument: Labor Income Tax)

(In percentage points)

Inflation

Real Interest Rate

No Monetary Accommodation
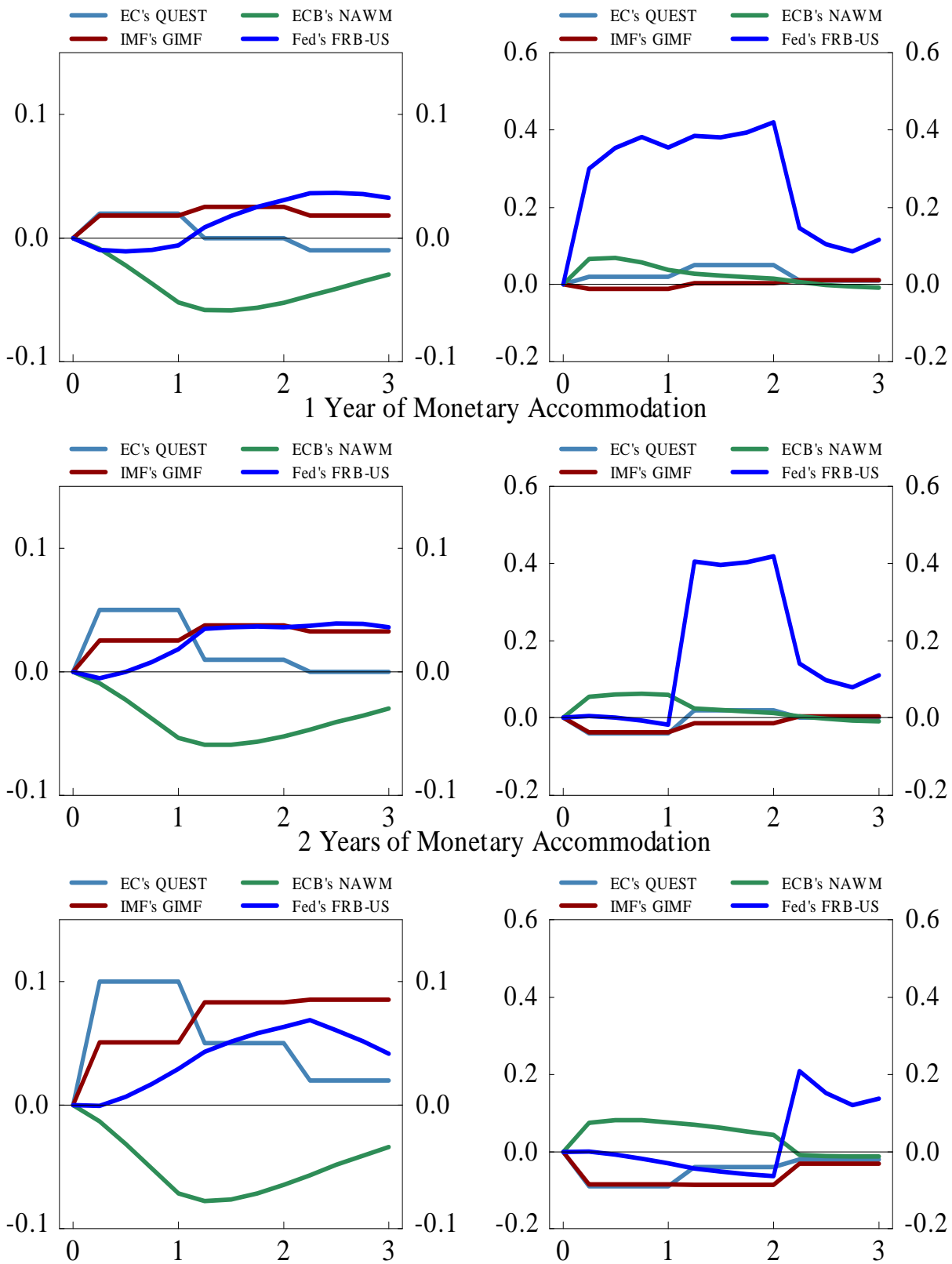
Figure 36. United States: Effect of 2 Years of Fiscal Stimulus on Consumption and Investment (Instrument: Labor Income Tax)

$$
\text { (In percent) }
$$

Consumption Investment No Monetary Accommodation
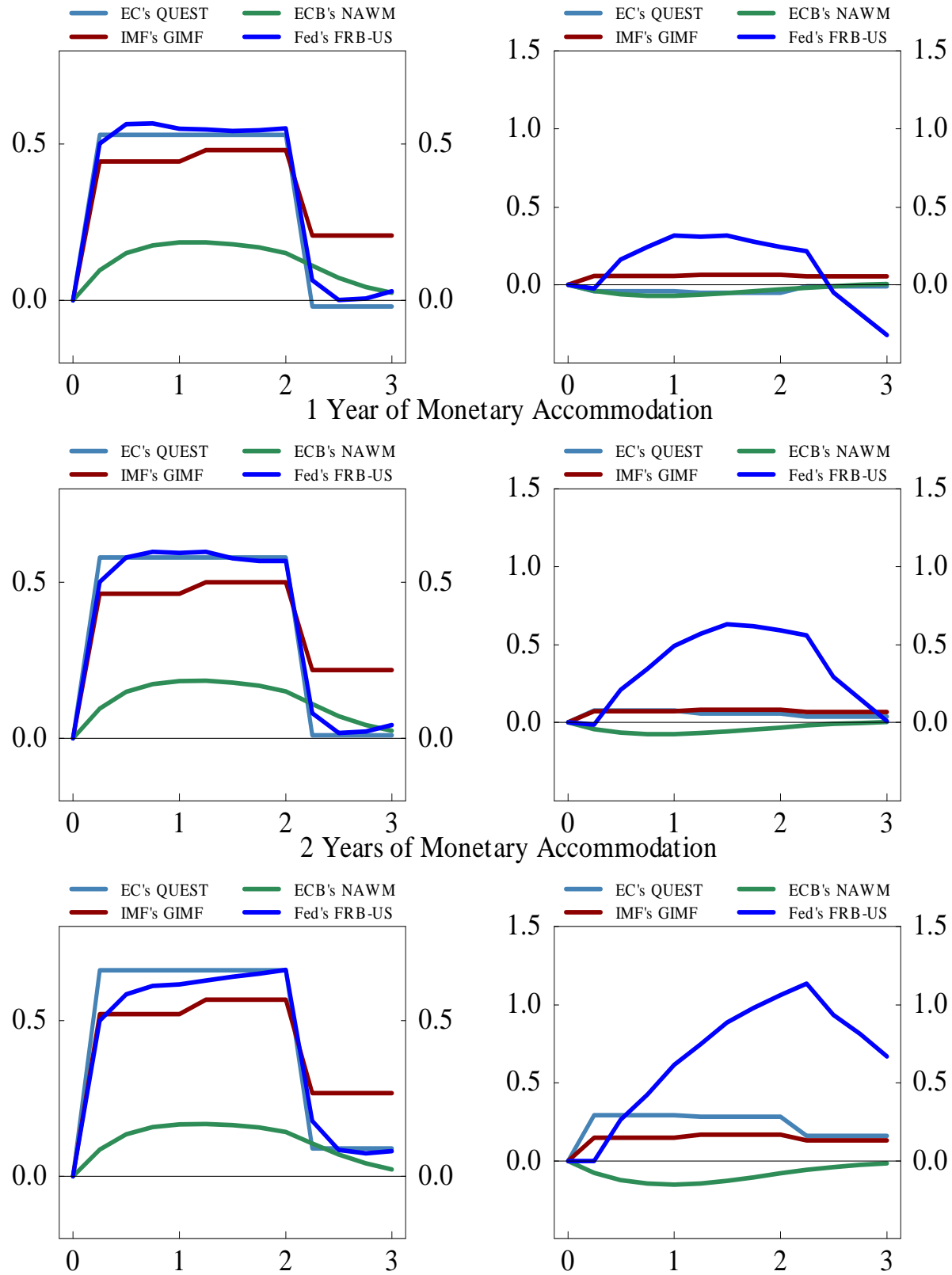
Figure 37. United States: Effect of 2 Years of Fiscal Stimulus on Real GDP (Instrument: Consumption Tax)

$$
\text { (In percent) }
$$
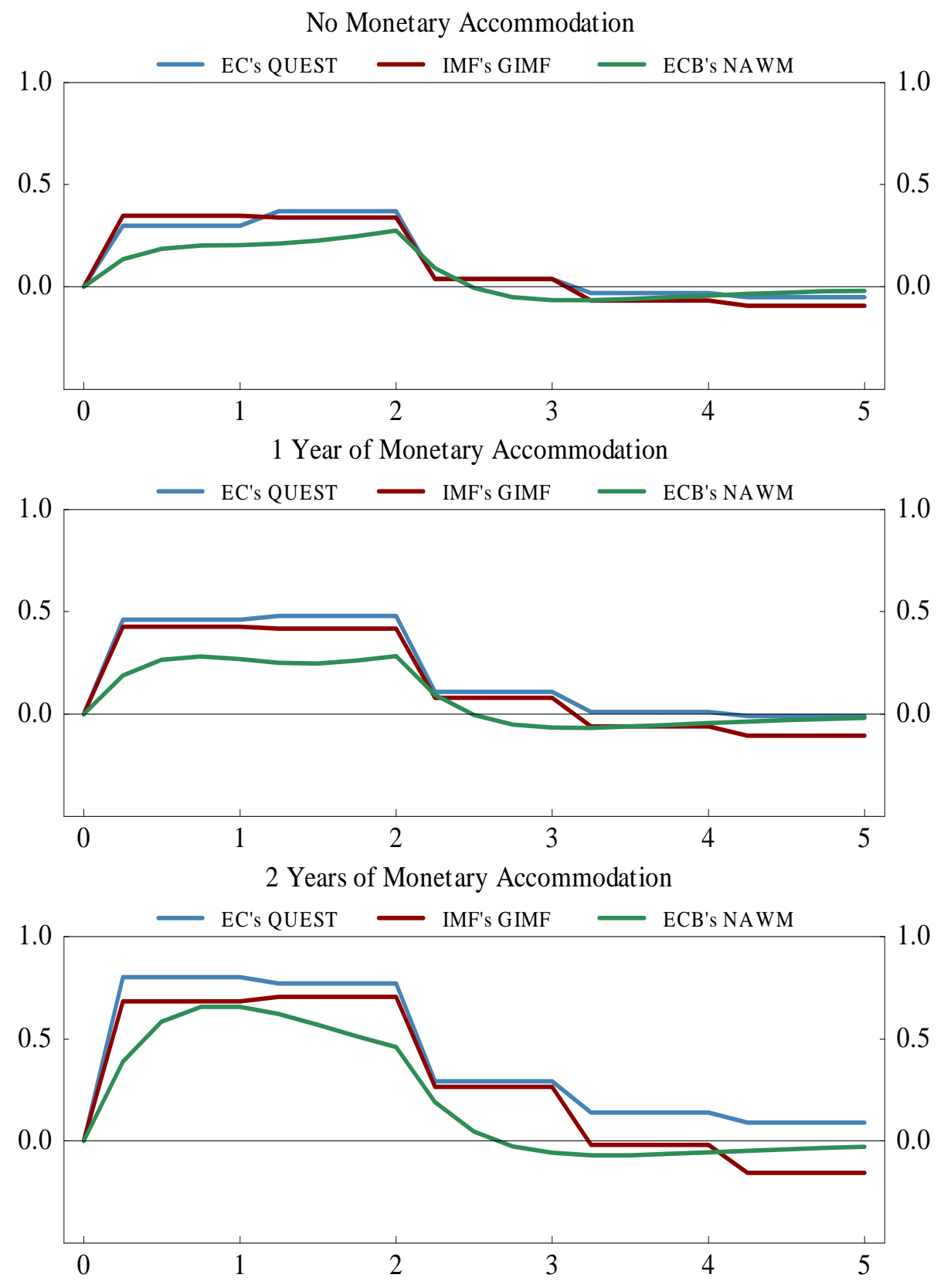
Figure 38. United States: Effect of 2 Years of Fiscal Stimulus on Inflation and the Real Interest Rate (Instrument: Consumption Tax)

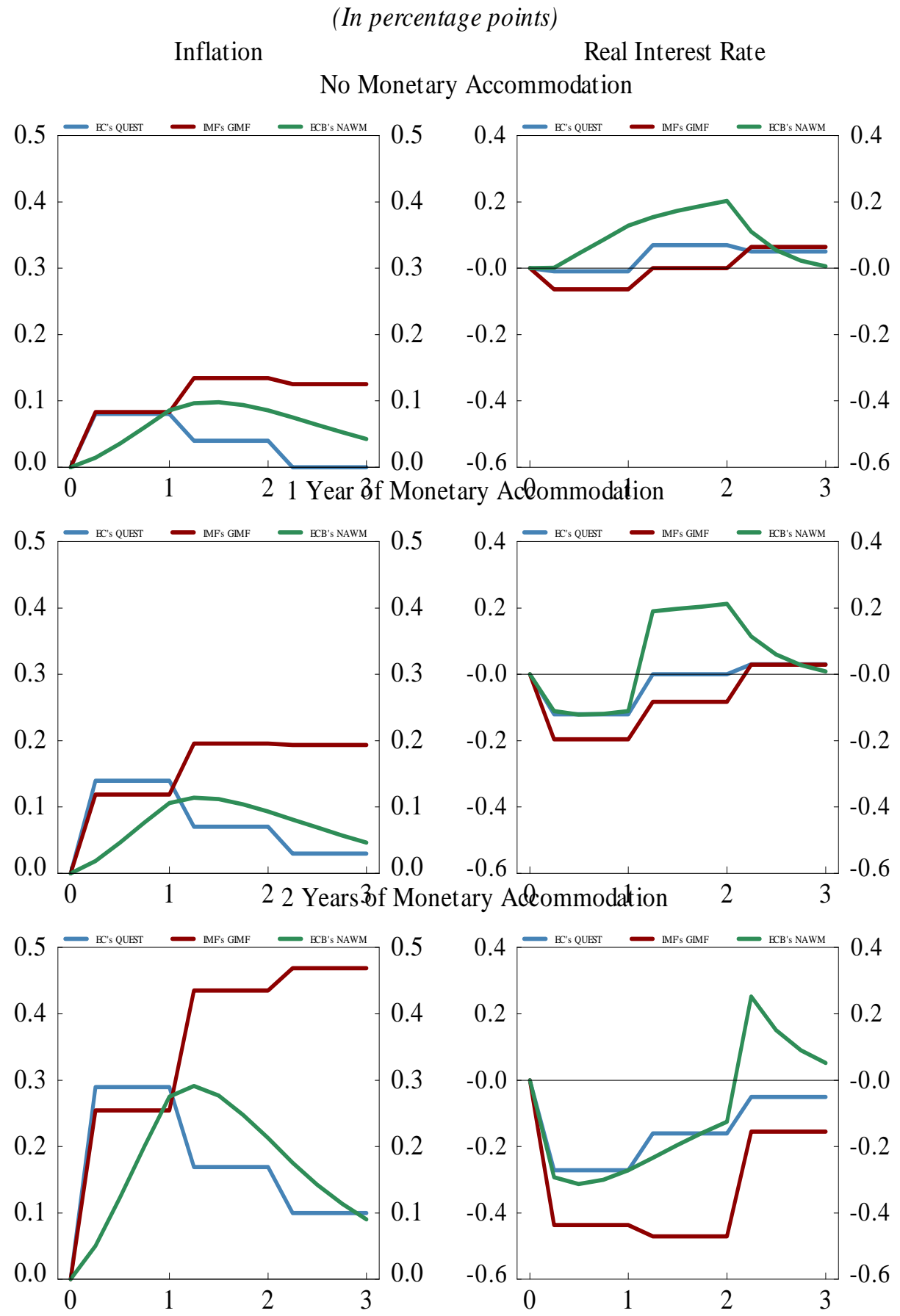


Figure 39. United States: Effect of 2 Years of Fiscal Stimulus on Consumption and Investment (Instrument: Consumption Tax)

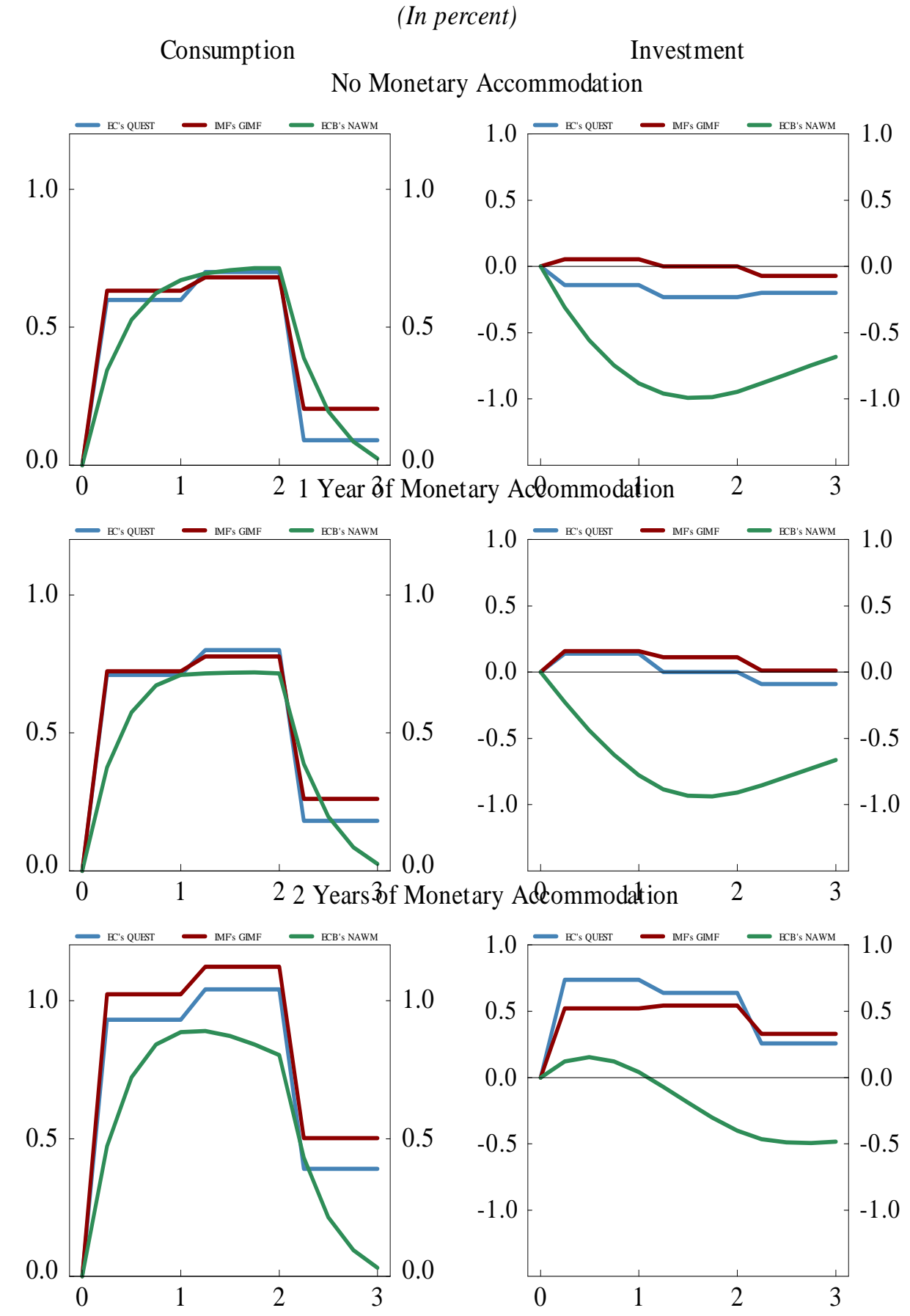


Figure 40. United States: Effect of 2 Years of Fiscal Stimulus on Real GDP (Instrument: Corporate Income Tax)

$$
\text { (In percent) }
$$
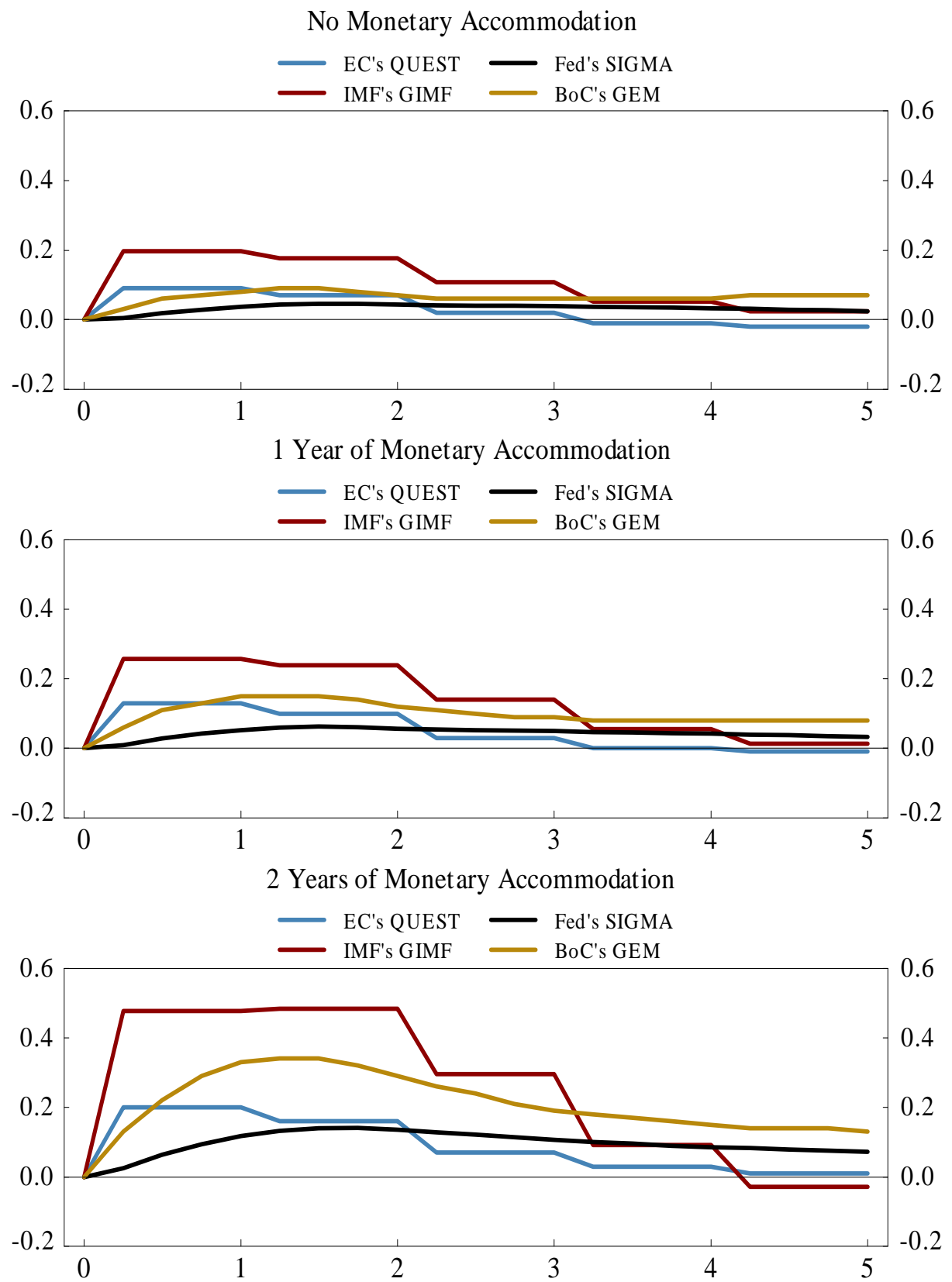
Figure 41. United States: Effect of 2 Years of Fiscal Stimulus on Inflation and the Real Interest Rate (Instrument: Corporate Income Tax)

(In percentage points)

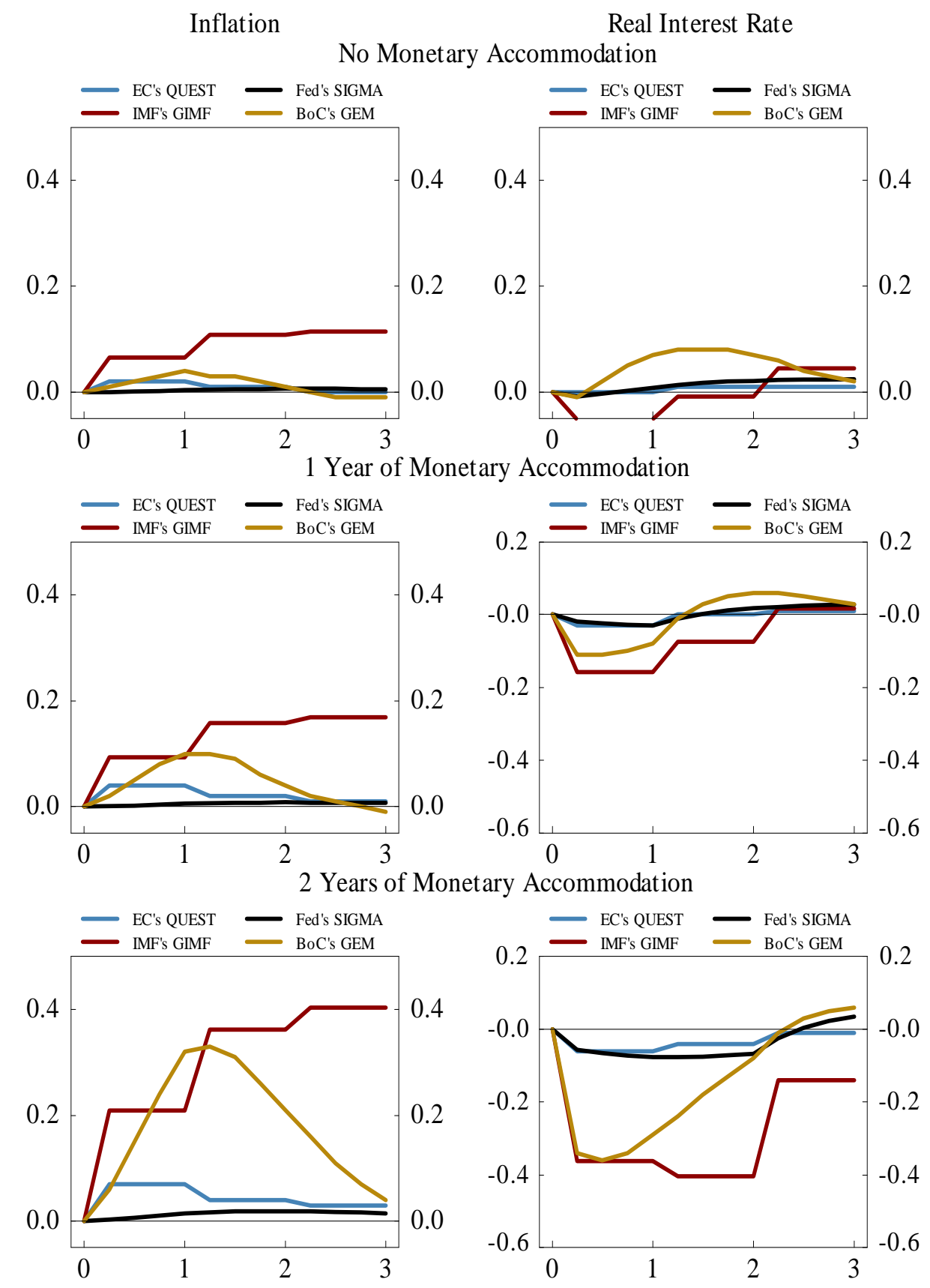


Figure 42. United States: Effect of 2 Years of Fiscal Stimulus on Consumption and Investment (Instrument: Corporate Income Tax)

(In percent)

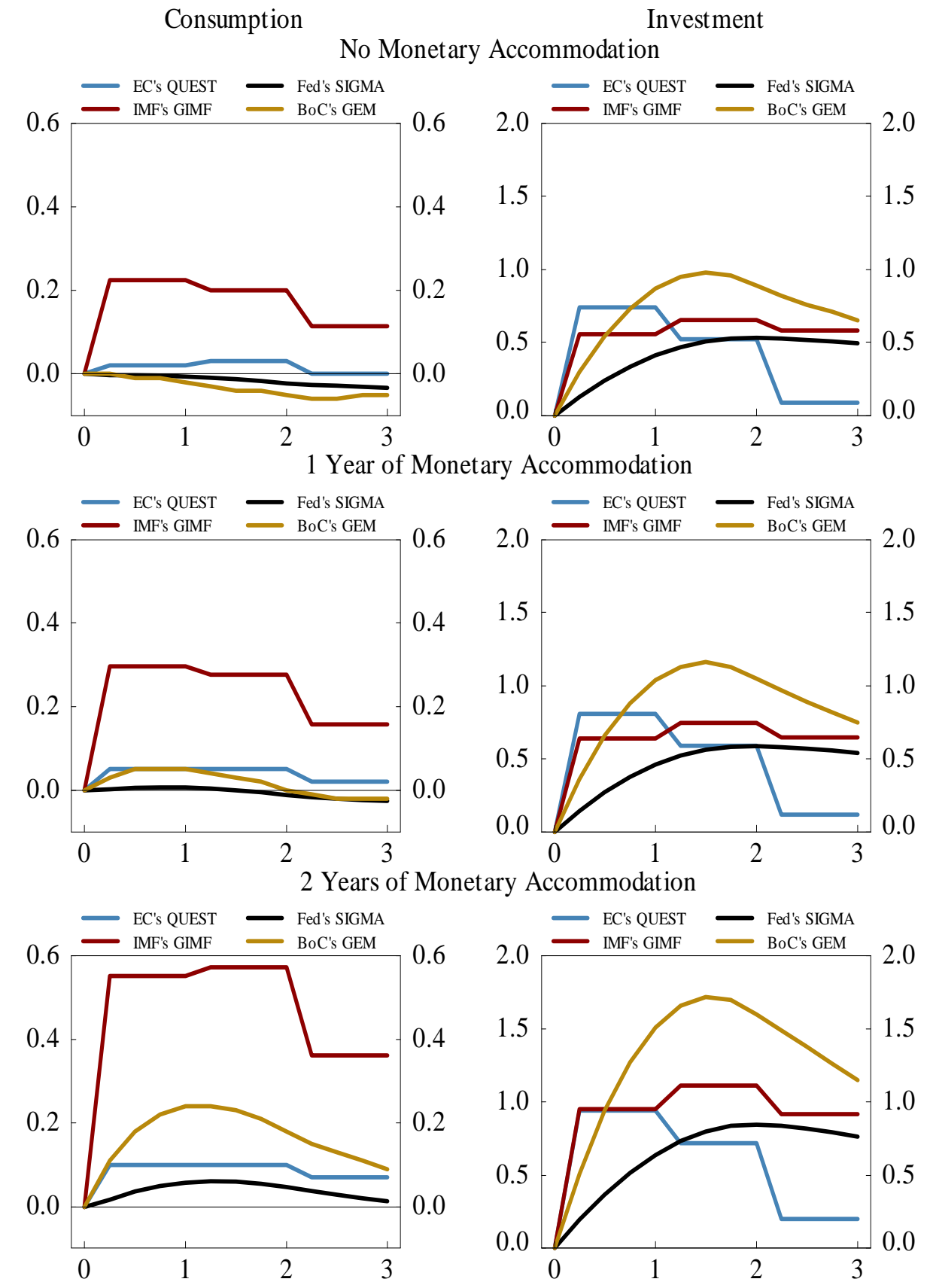


Figure 43. Euro Area / European Union: Effect of 1 Year of Fiscal Stimulus on Real GDP (Instrument: Government Investment)

$$
\text { (In percent) }
$$
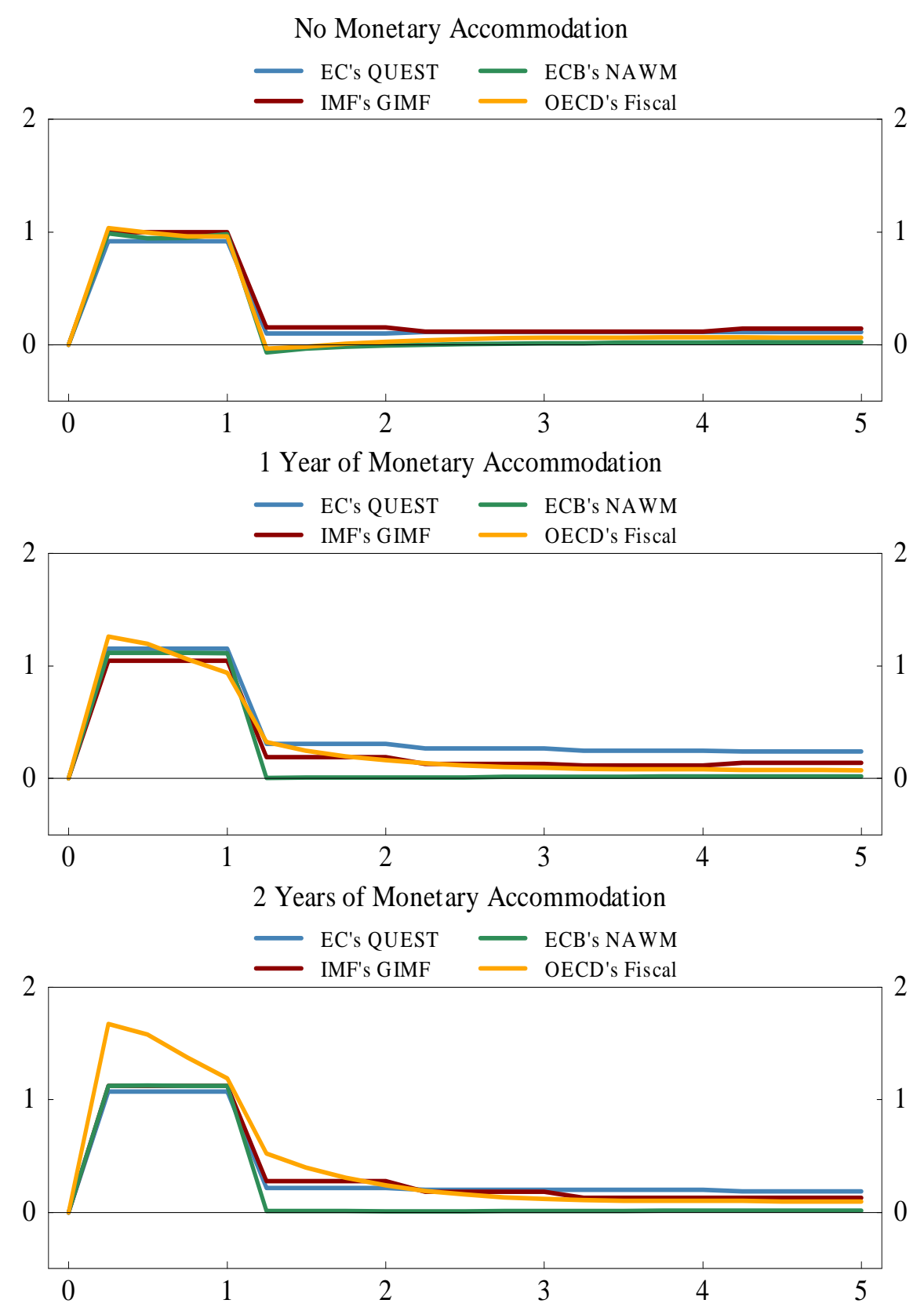
Figure 44. Euro Area / European Union: Effect of 1 Year of Fiscal Stimulus on Inflation and the Real Interest Rate (Instrument: Government Investment)

(In percentage points)

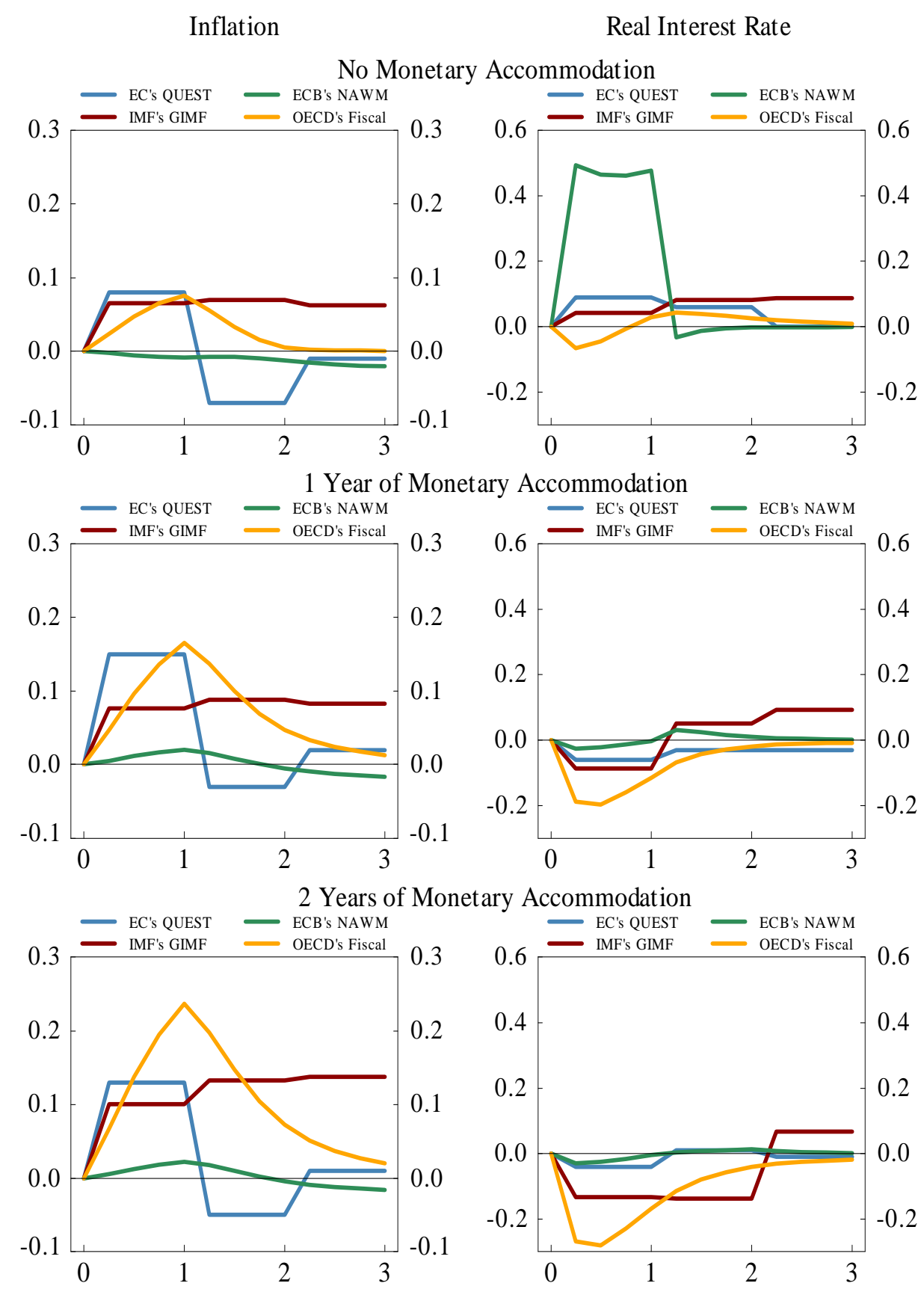


Figure 45. Euro Area / European Union: Effect of 1 Year of Fiscal Stimulus on Consumption and Investment (Instrument: Government Investment)

$$
\text { (In percent) }
$$

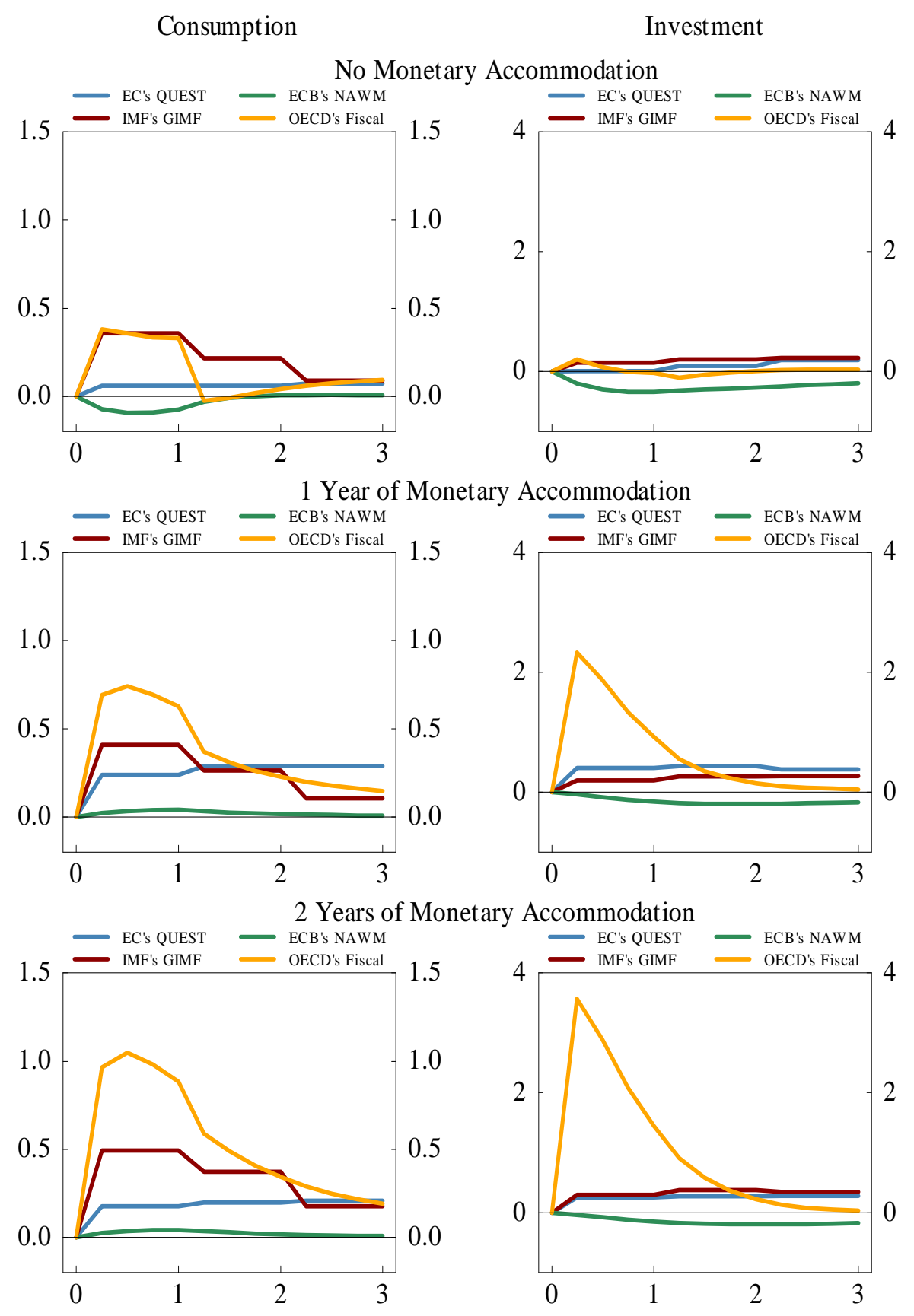


Figure 46. Euro Area / European Union: Effect of 1 Year of Fiscal Stimulus on Real GDP (Instrument: Government Consumption)

$$
\text { (In percent) }
$$
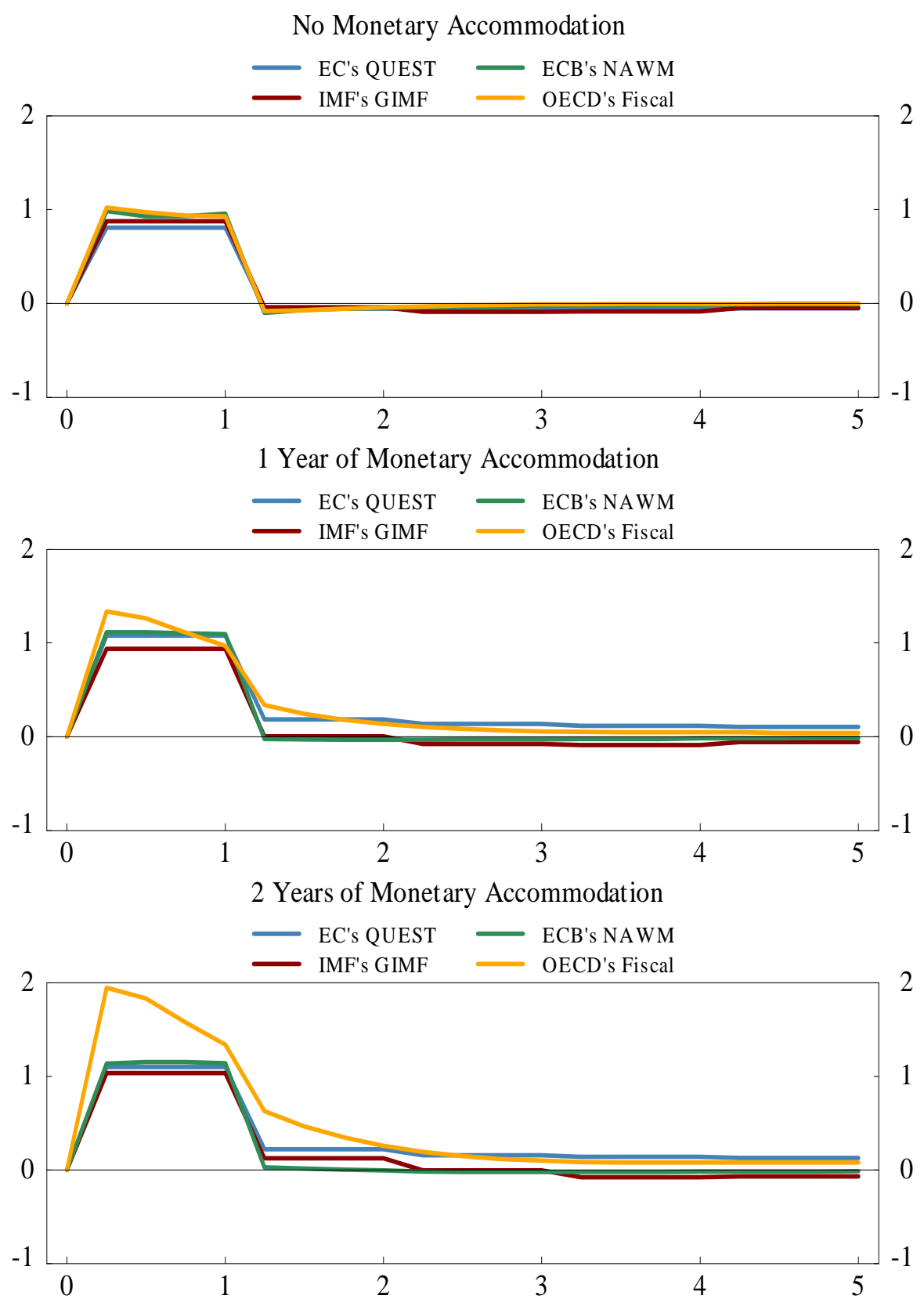
Figure 47. Euro Area / European Union: Effect of 1 Year of Fiscal Stimulus on Inflation and the Real Interest Rate (Instrument: Government Consumption)

(In percentage points)

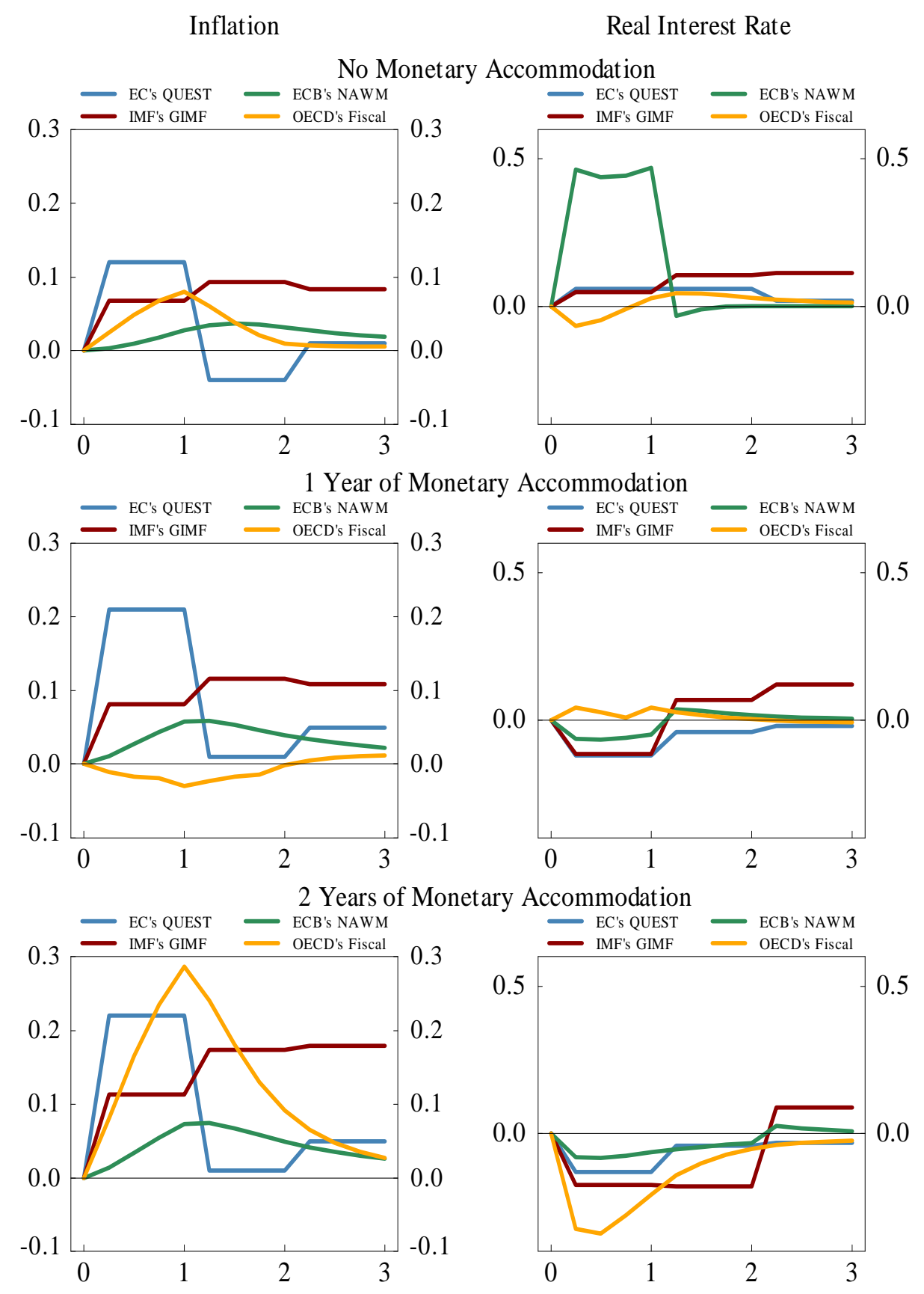


Figure 48. Euro Area / European Union: Effect of 1 Year of Fiscal Stimulus on Consumption and Investment (Instrument: Government Consumption)

(In percent)

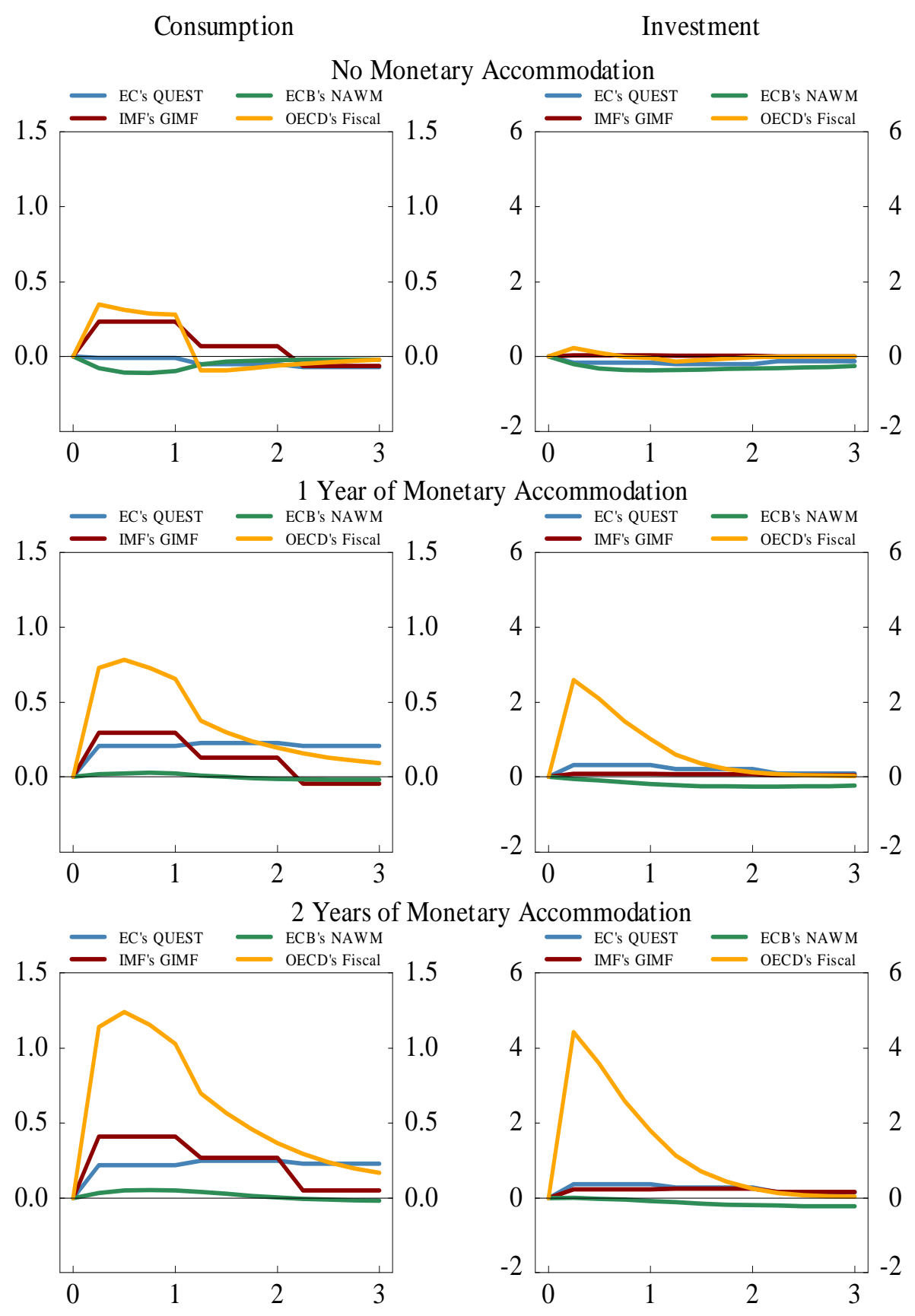


Figure 49. Euro Area / European Union: Effect of 1 Year of Fiscal Stimulus on Real GDP (Instrument: General Transfers)

$$
\text { (In percent) }
$$
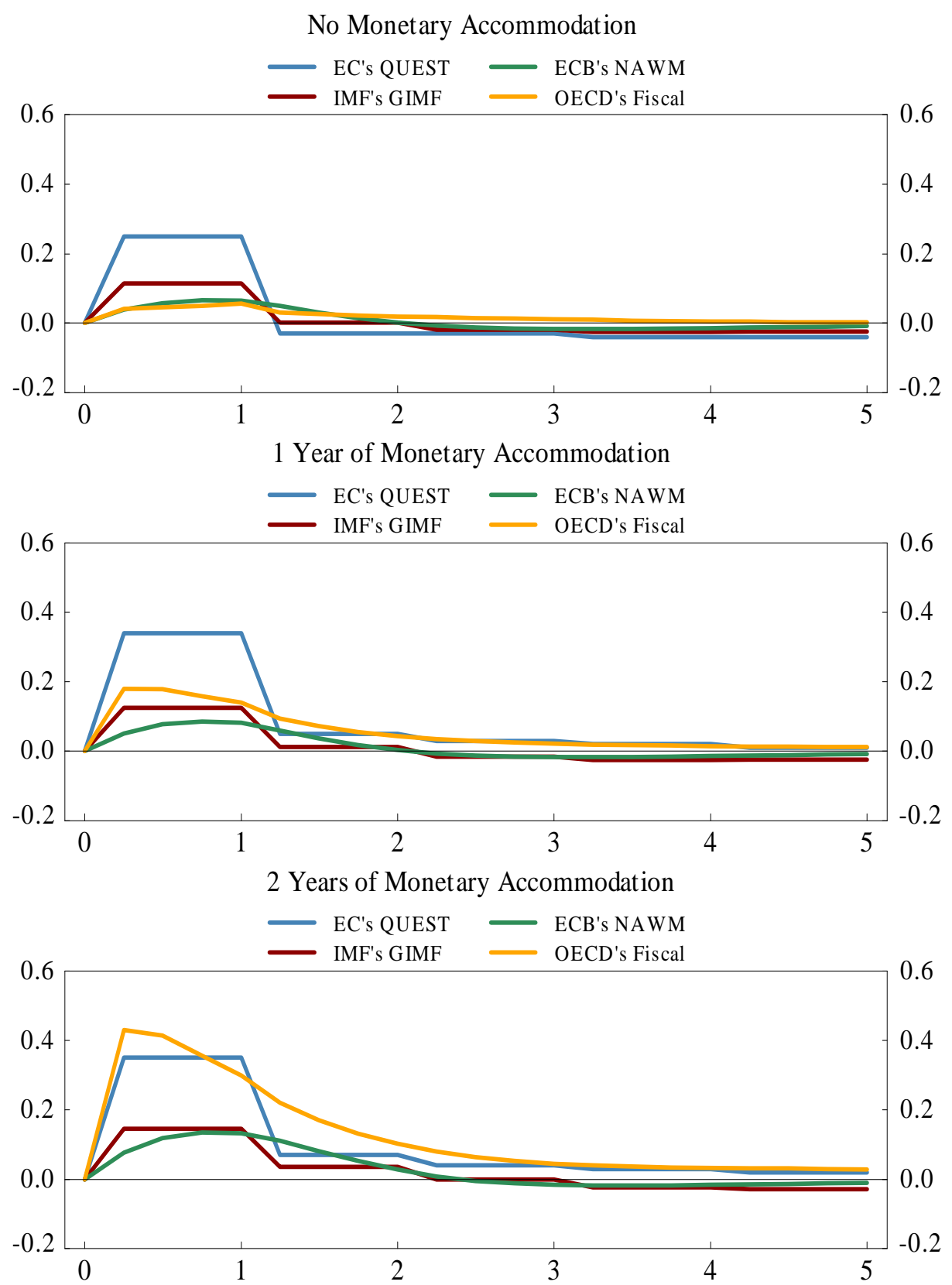
Figure 50. Euro Area / European Union: Effect of 1 Year of Fiscal Stimulus on Inflation and the Real Interest Rate (Instrument: General Transfers)

(In percentage points)

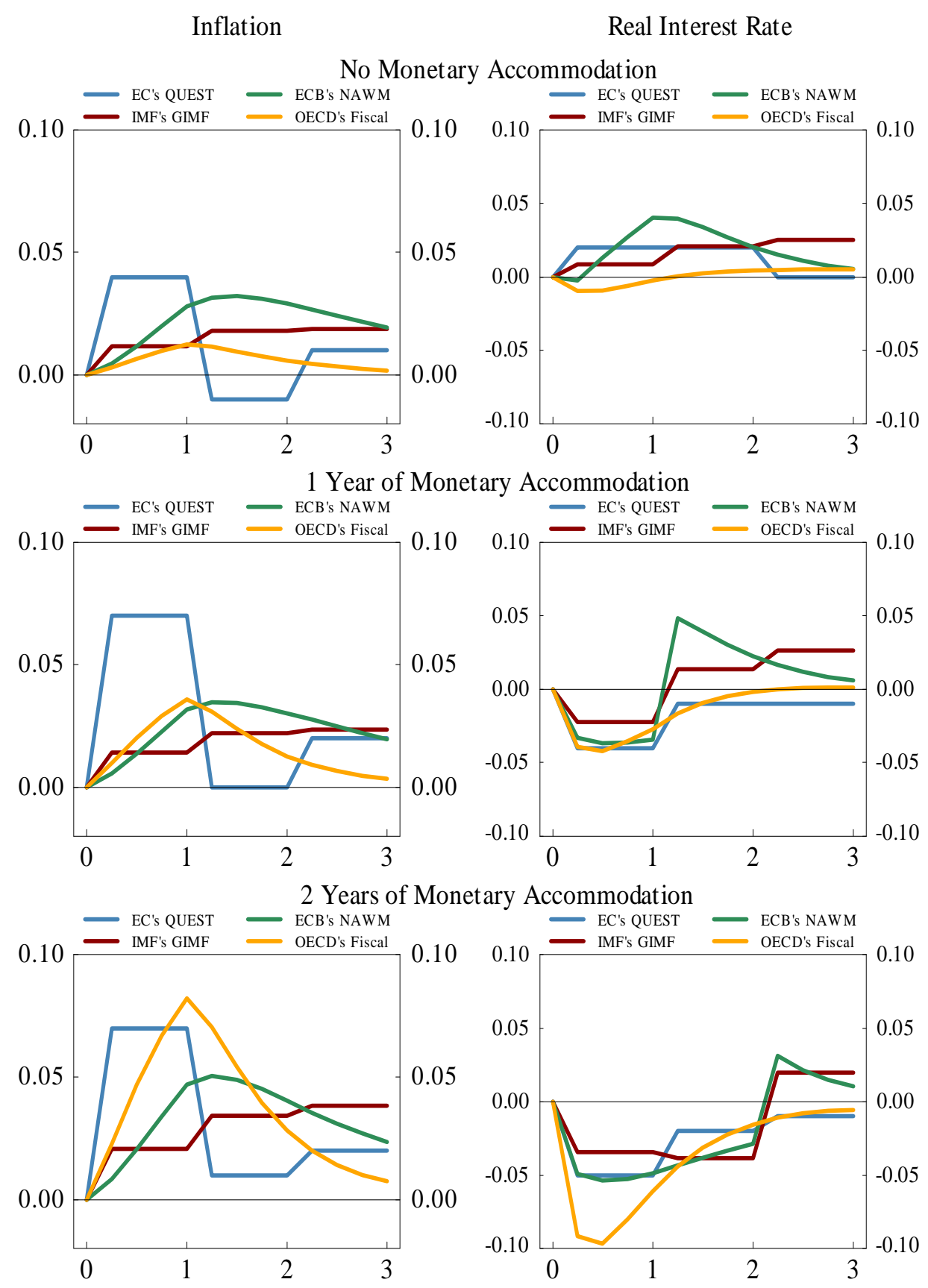


Figure 51. Euro Area / European Union: Effect of 1 Year of Fiscal Stimulus on Consumption and Investment (Instrument: General Transfers)

(In percent)

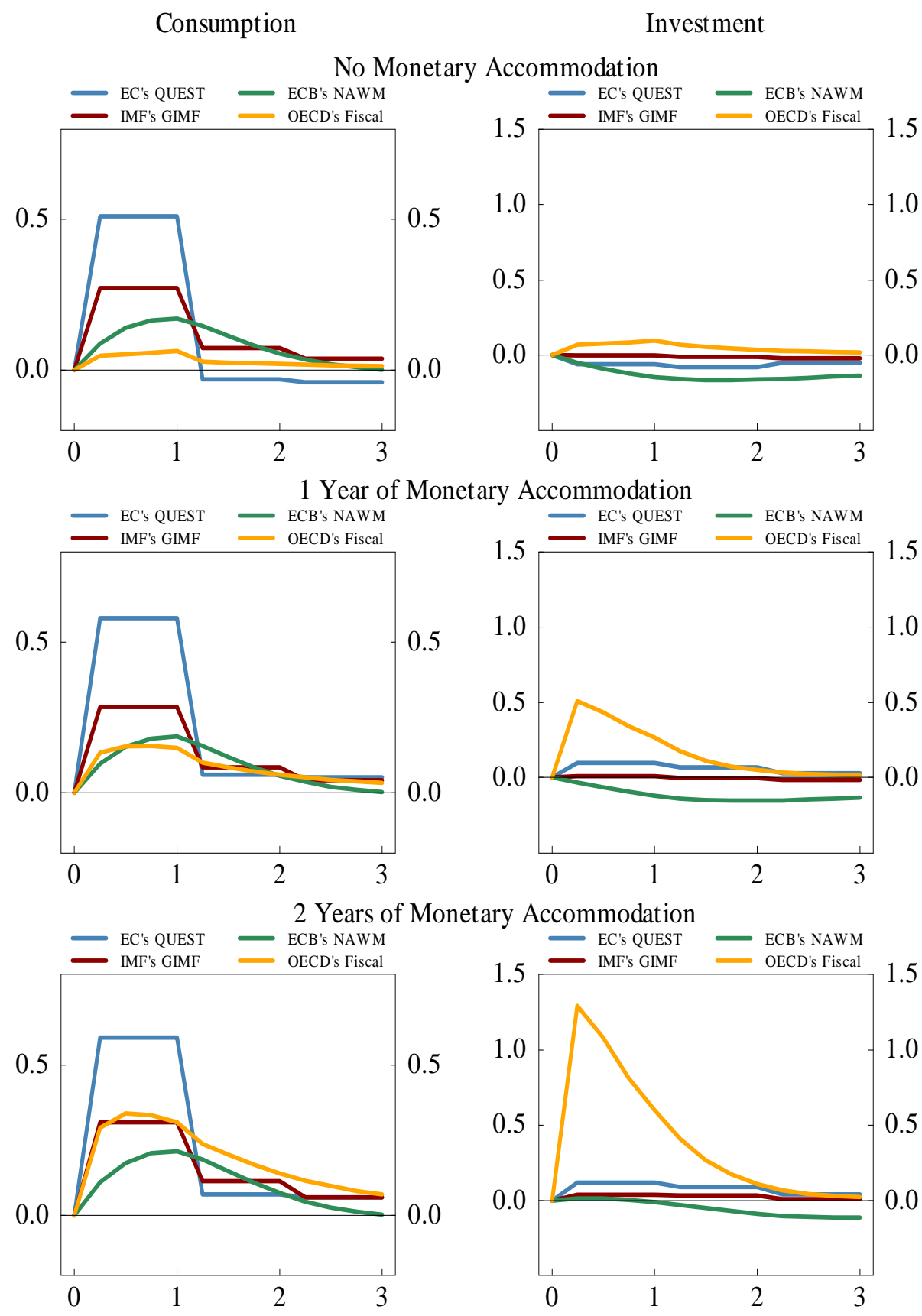


Figure 52. Euro Area / European Union: Effect of 1 Year of Fiscal Stimulus on Real GDP (Instrument: Targeted Transfers)

$$
\text { (In percent) }
$$
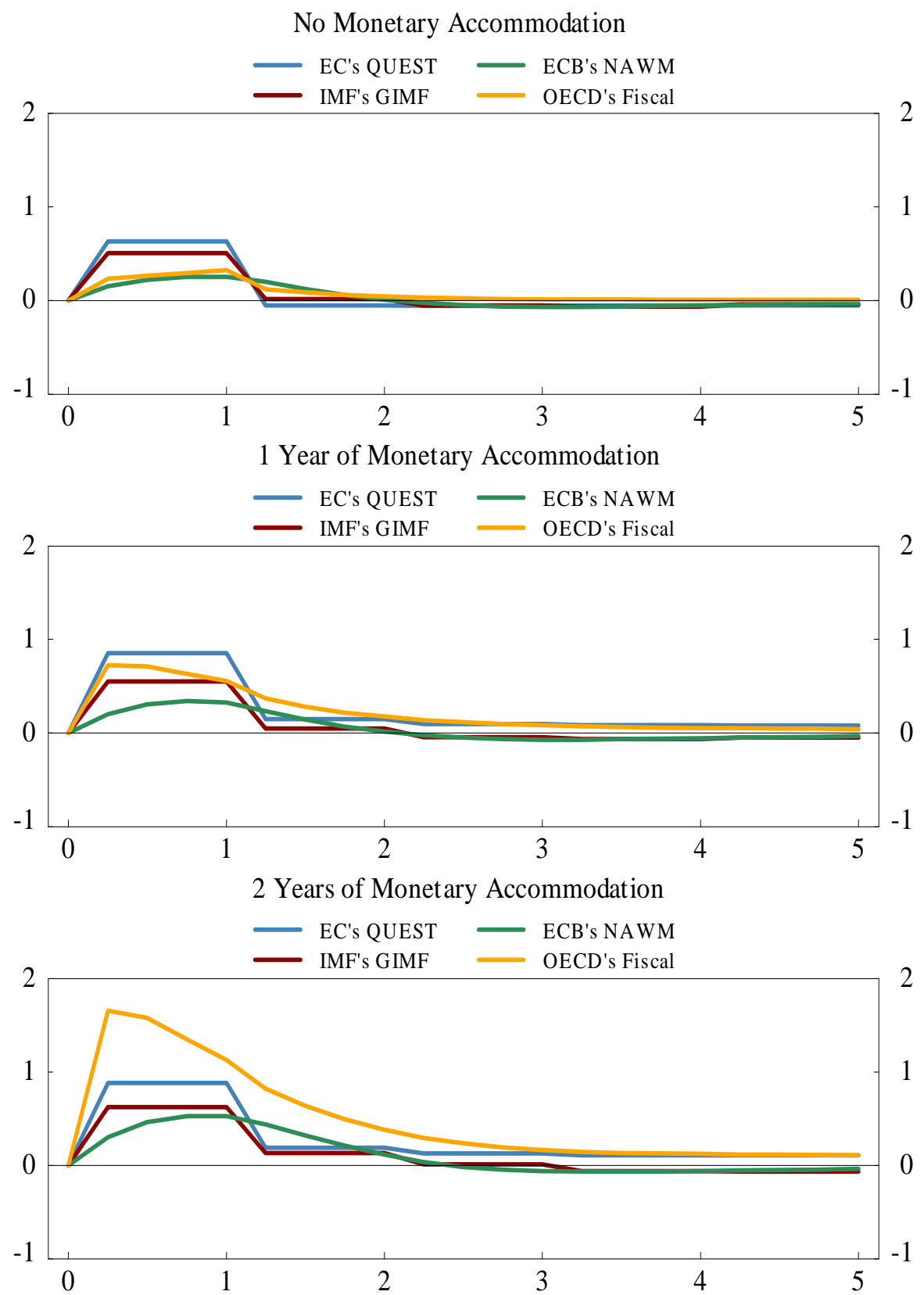
Figure 53. Euro Area / European Union: Effect of 1 Year of Fiscal Stimulus on Inflation and the Real Interest Rate (Instrument: Targeted Transfers)

(In percentage points)

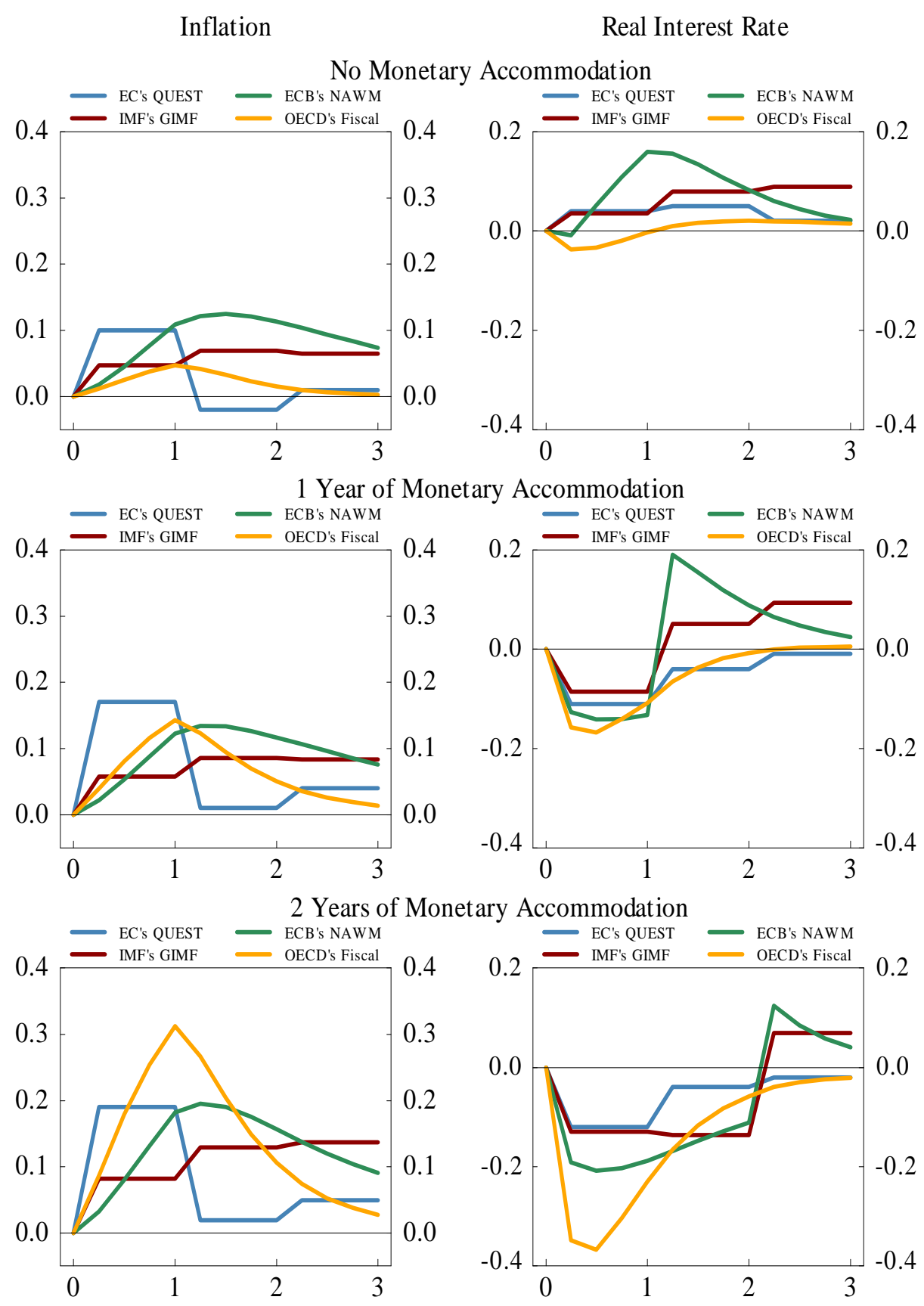


Figure 54. Euro Area / European Union: Effect of 1 Year of Fiscal Stimulus on Consumption and Investment (Instrument: Targeted Transfers)

(In percent)

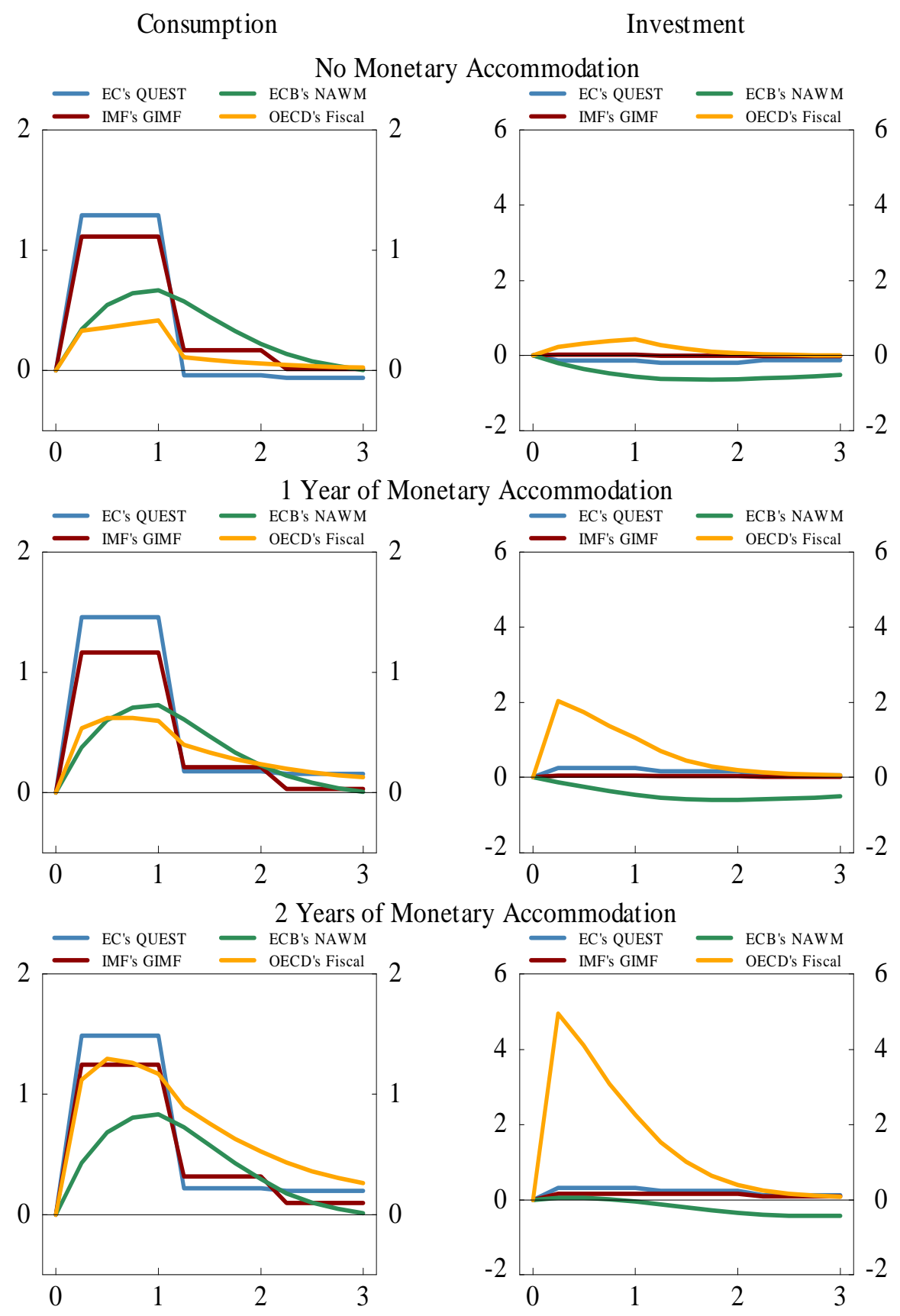


Figure 55. Euro Area / European Union: Effect of 1 Year of Fiscal Stimulus on Real GDP (Instrument: Labor Income Tax)

$$
\text { (In percent) }
$$
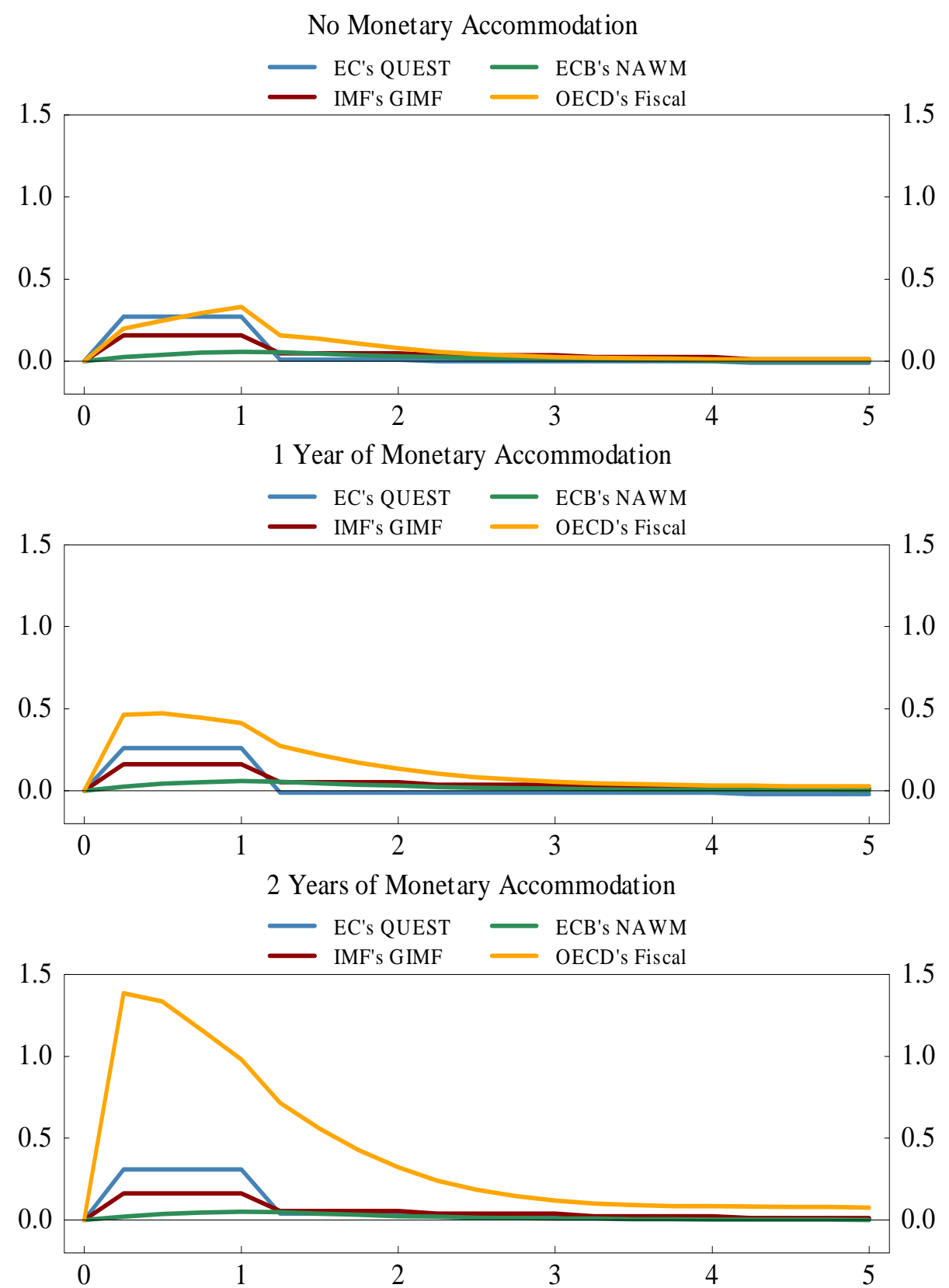
Figure 56. Euro Area / European Union: Effect of 1 Year of Fiscal Stimulus on Inflation and the Real Interest Rate (Instrument: Labor Income Tax)

(In percentage points)

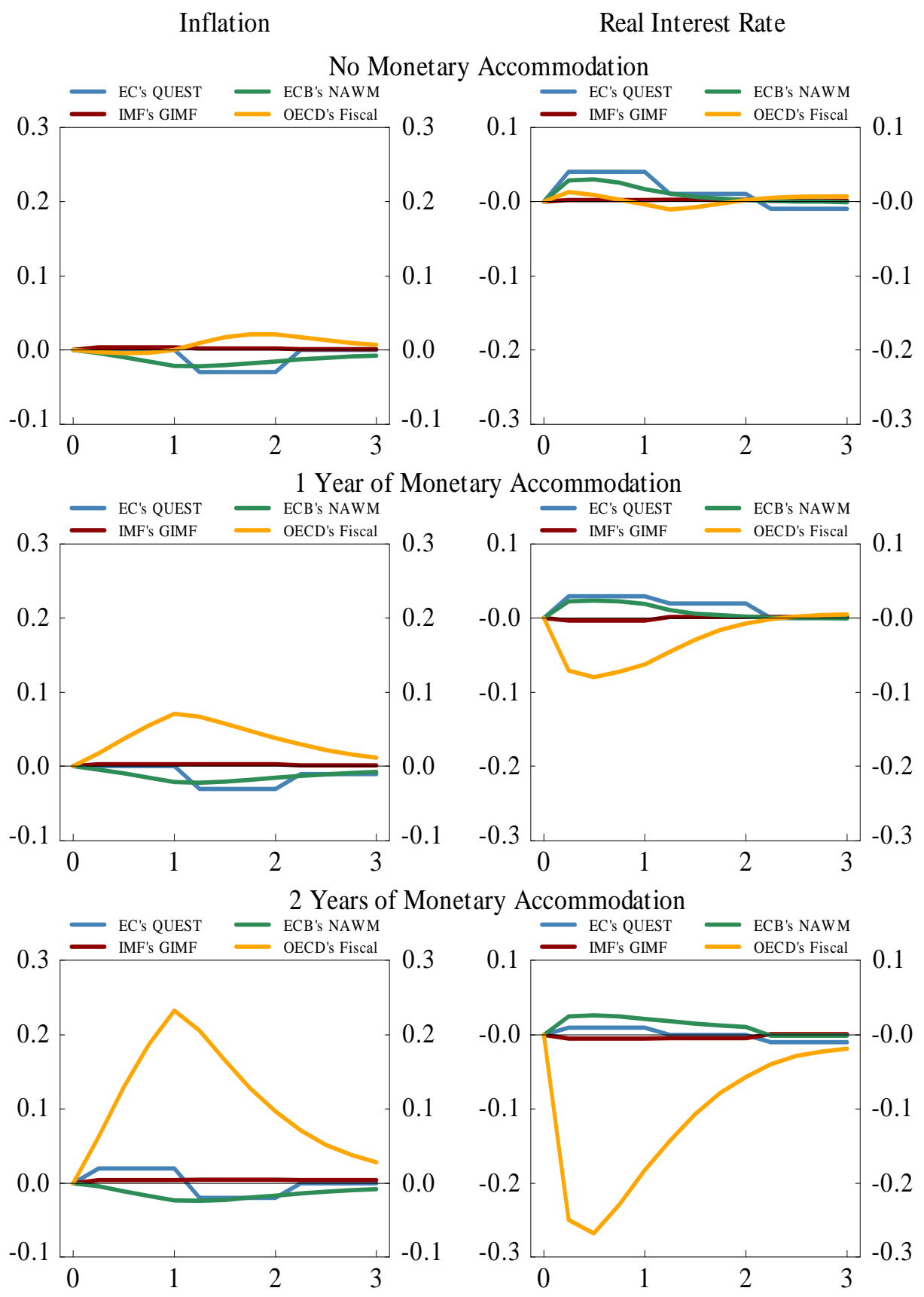


Figure 57. Euro Area / European Union: Effect of 1 Year of Fiscal Stimulus on Consumption and Investment (Instrument: Labor Income Tax)

(In percent)

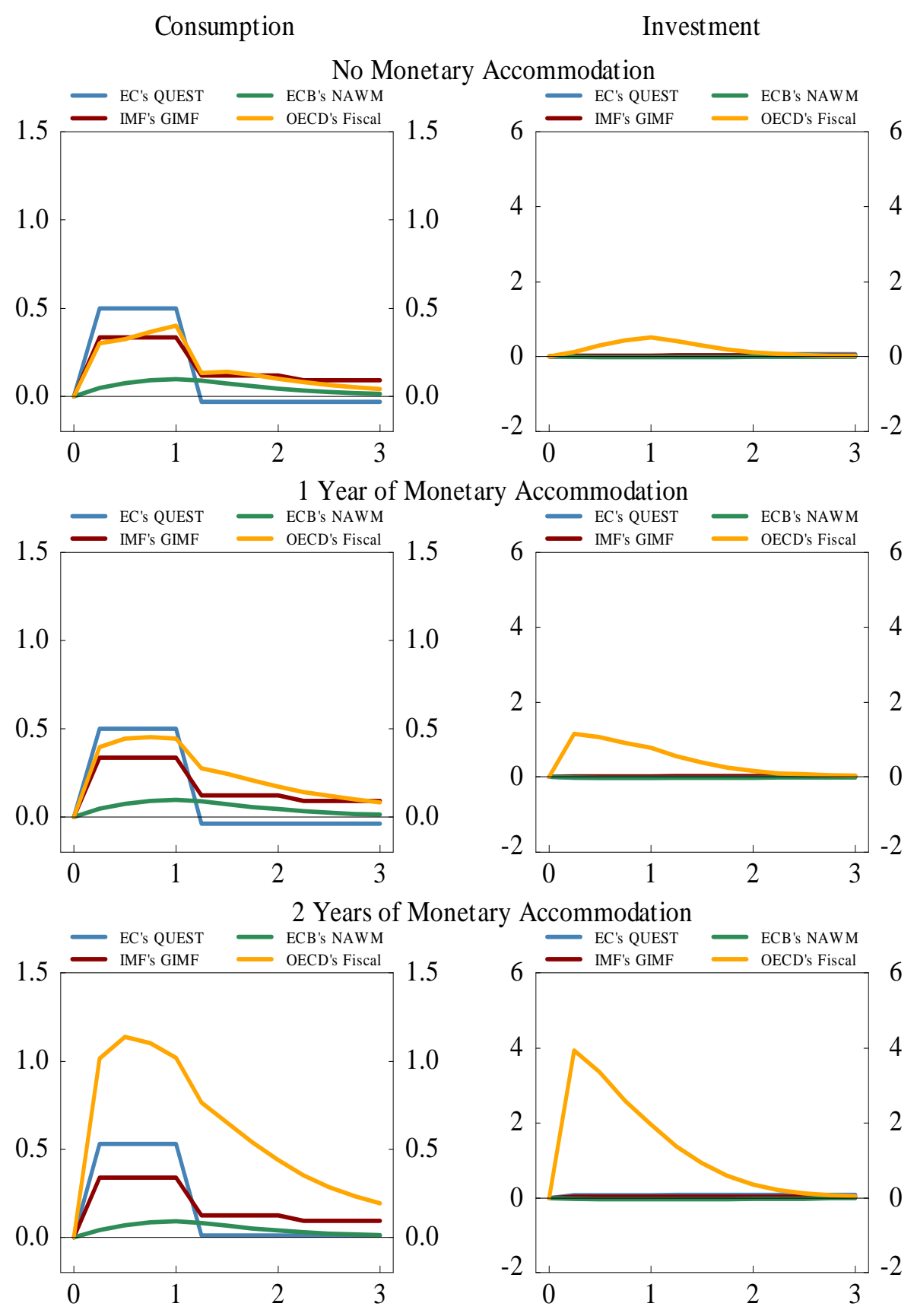


Figure 58. Euro Area / European Union: Effect of 1 Year of Fiscal Stimulus on Real GDP (Instrument: Consumption Tax)

$$
\text { (In percent) }
$$
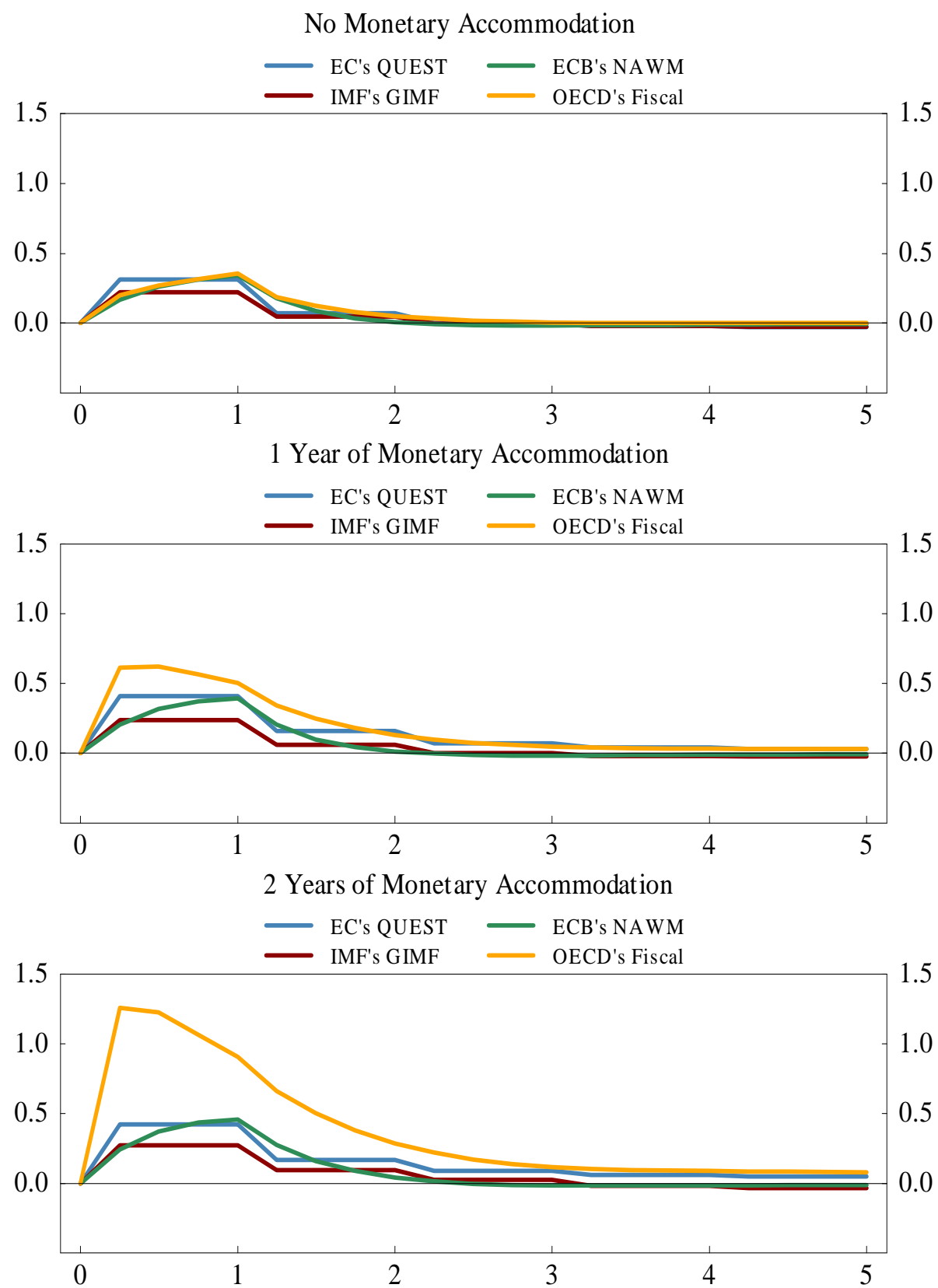
Figure 59. Euro Area / European Union: Effect of 1 Year of Fiscal Stimulus on Inflation and the Real Interest Rate (Instrument: Consumption Tax)

(In percentage points)

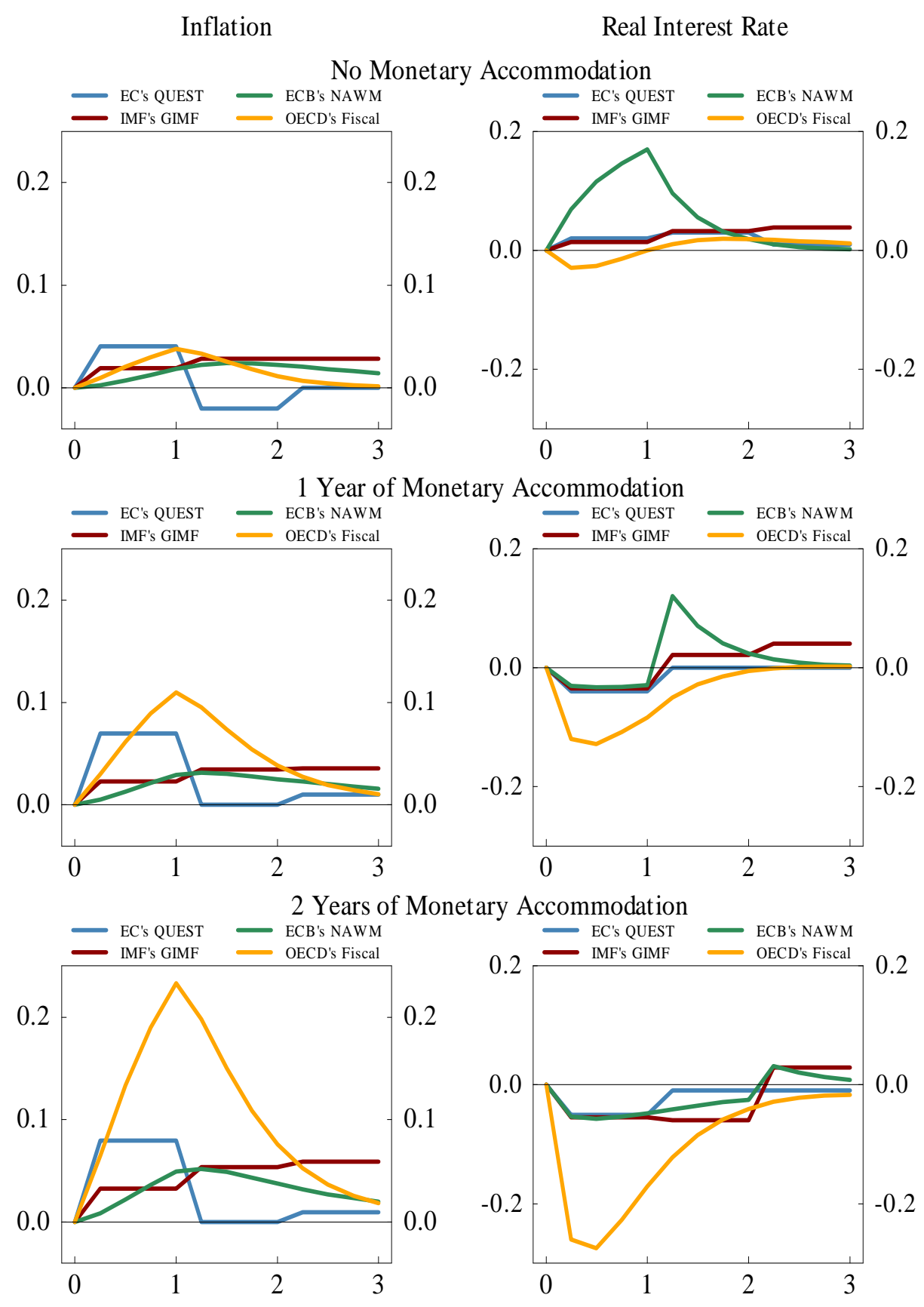


Figure 60. Euro Area / European Union: Effect of 1 Year of Fiscal Stimulus on Consumption and Investment (Instrument: Consumption Tax)

(In percent)

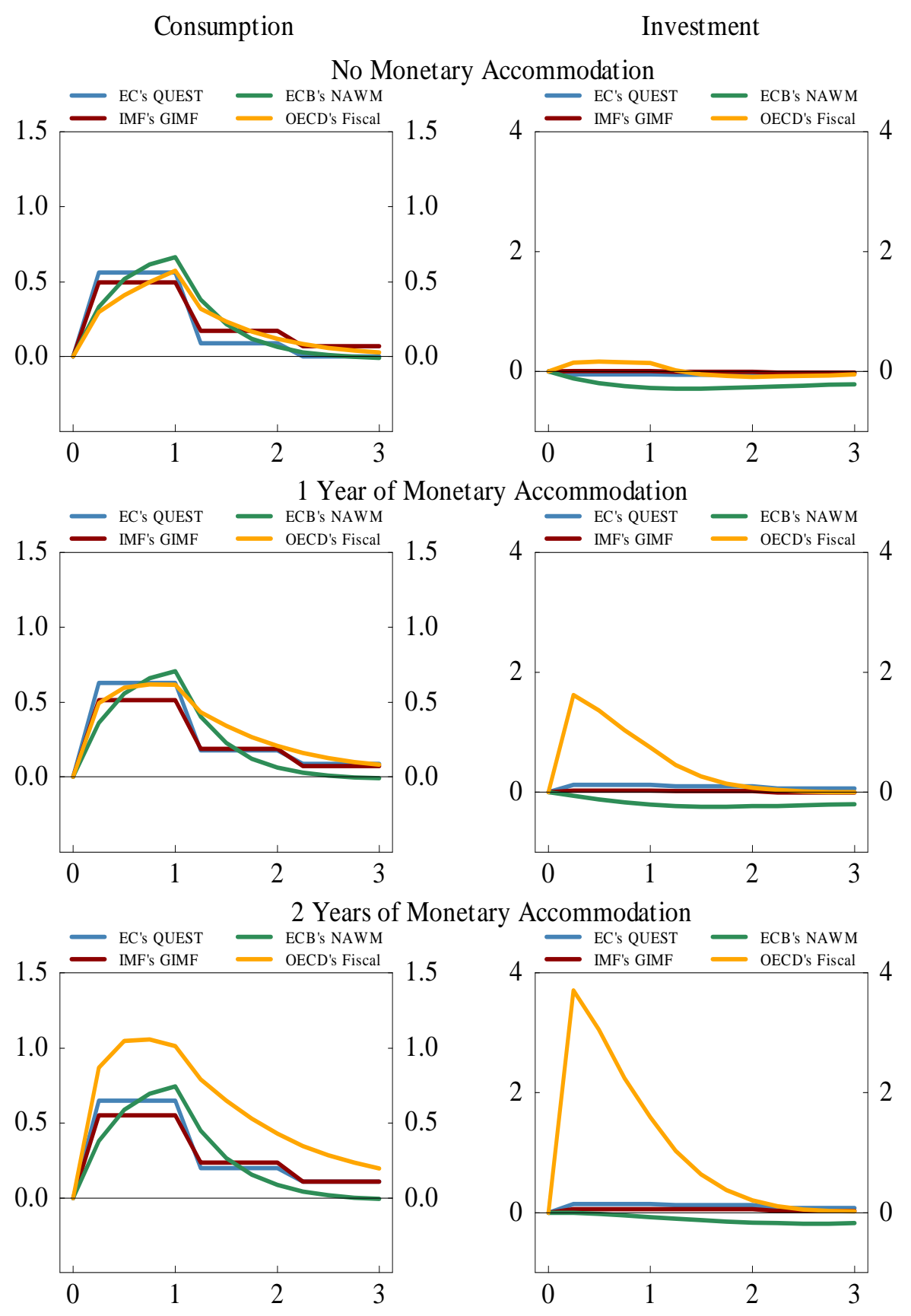


Figure 61. Euro Area / European Union: Effect of 1 Year of Fiscal Stimulus on Real GDP (Instrument: Corporate Income Tax)

$$
\text { (In percent) }
$$
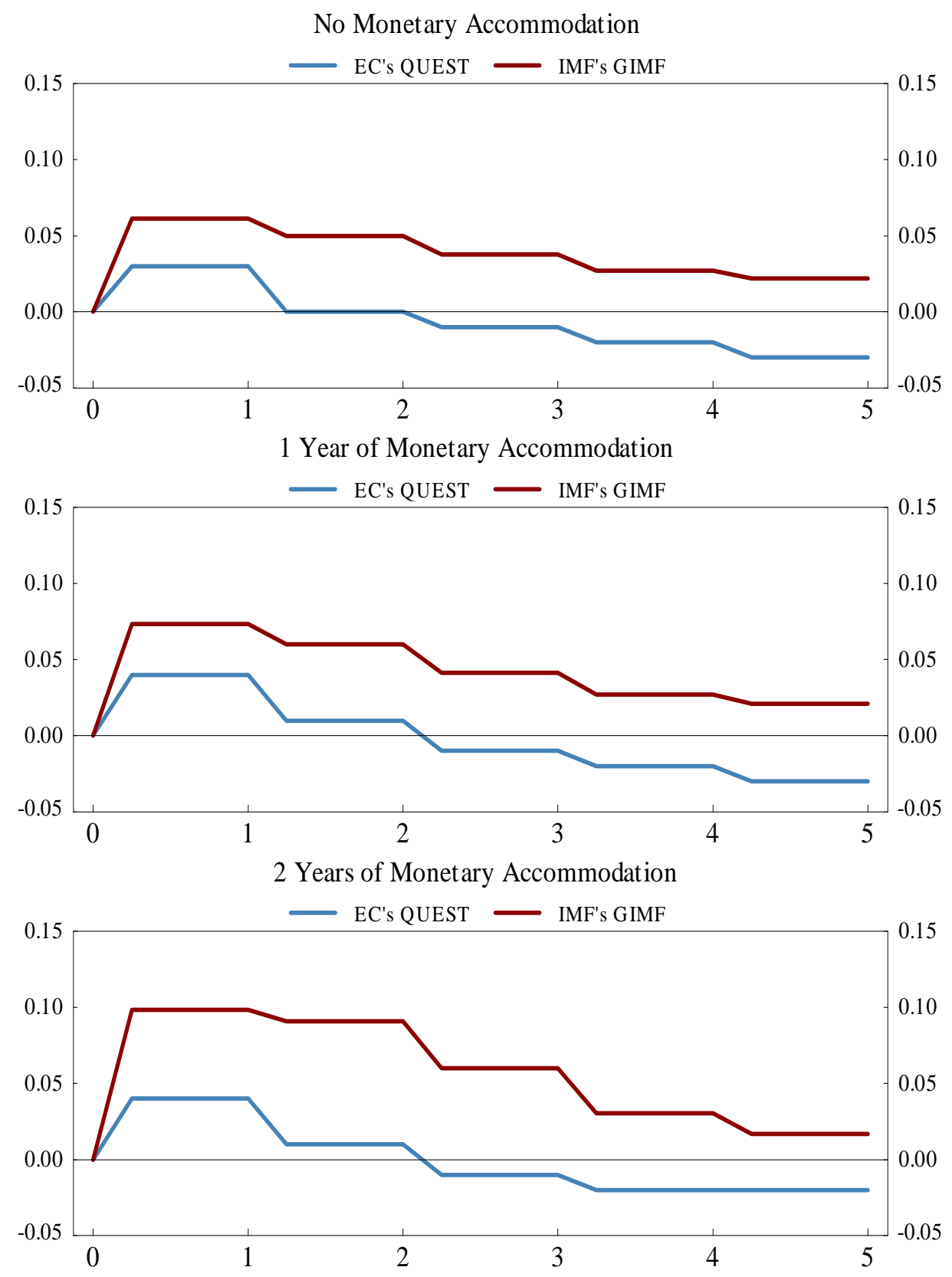
Figure 62. Euro Area / European Union: Effect of 1 Year of Fiscal Stimulus on Inflation and the Real Interest Rate (Instrument: Corporate Income Tax)

(In percentage points)

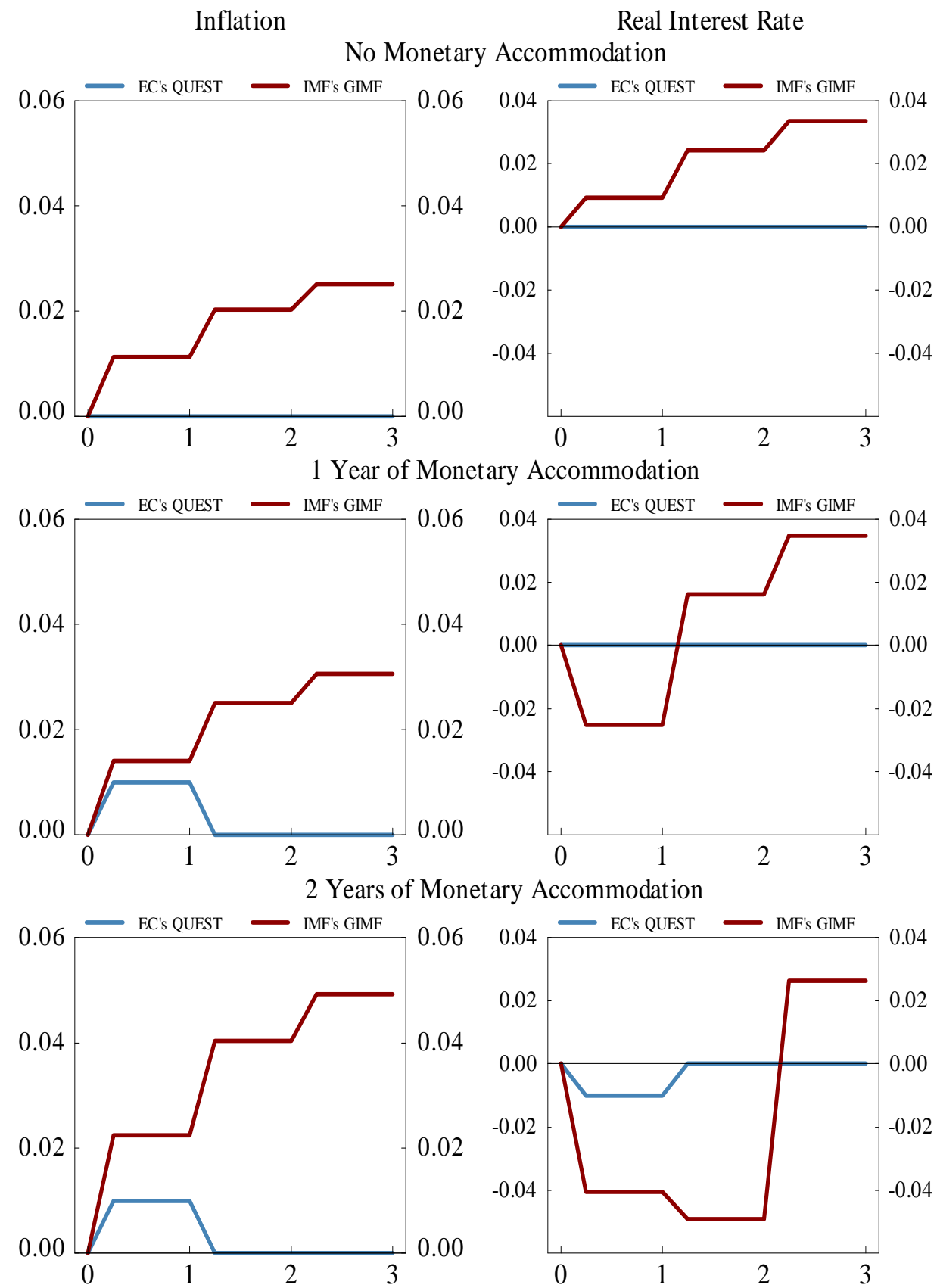


Figure 63. Euro Area / European Union: Effect of 1 Year of Fiscal Stimulus on Consumption and Investment (Instrument: Corporate Income Tax)

$$
\text { (In percent) }
$$

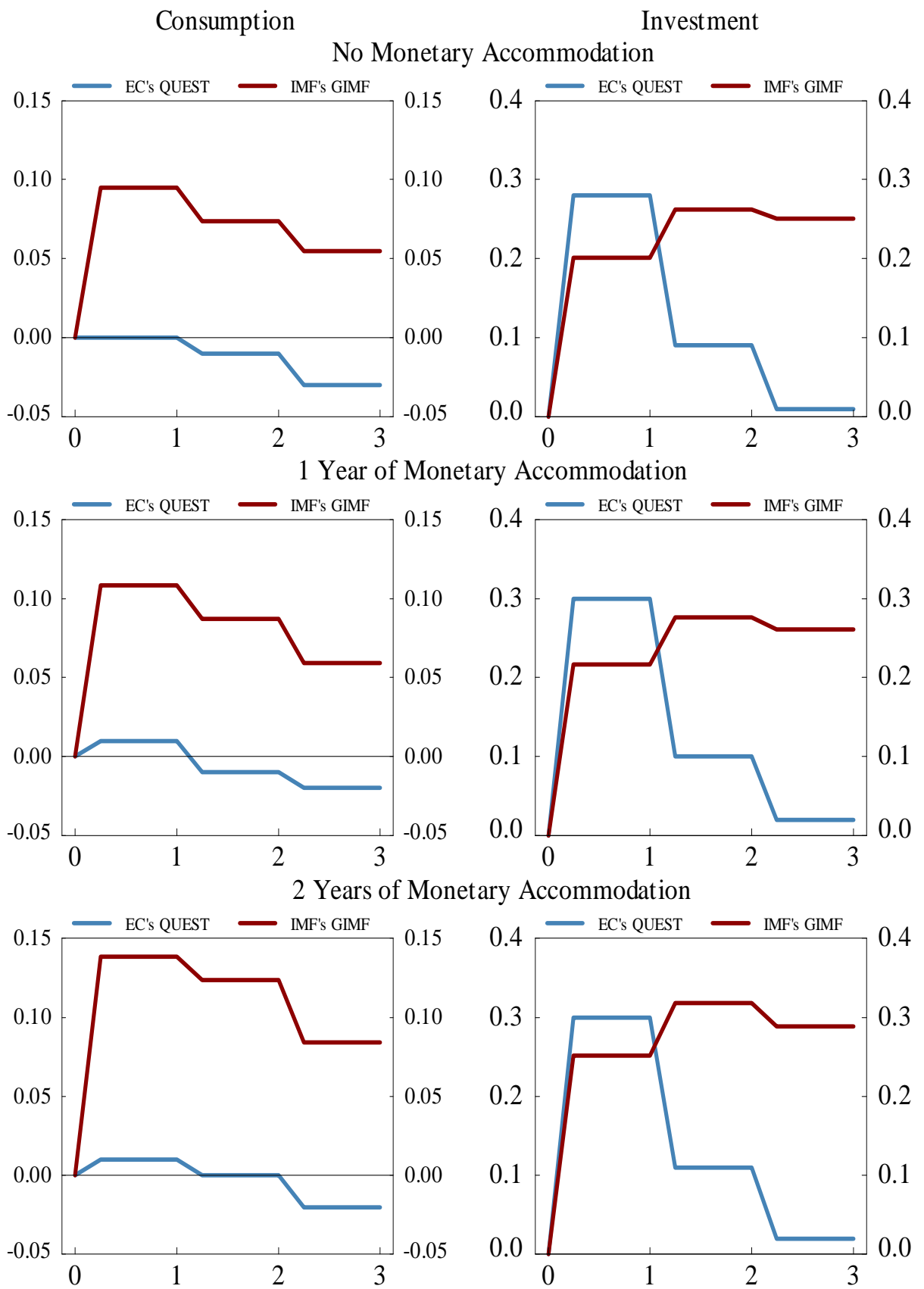


Figure 64. Euro Area / European Union: Effect of 2 Years of Fiscal Stimulus on Real GDP (Instrument: Government Investment)

$$
\text { (In percent) }
$$
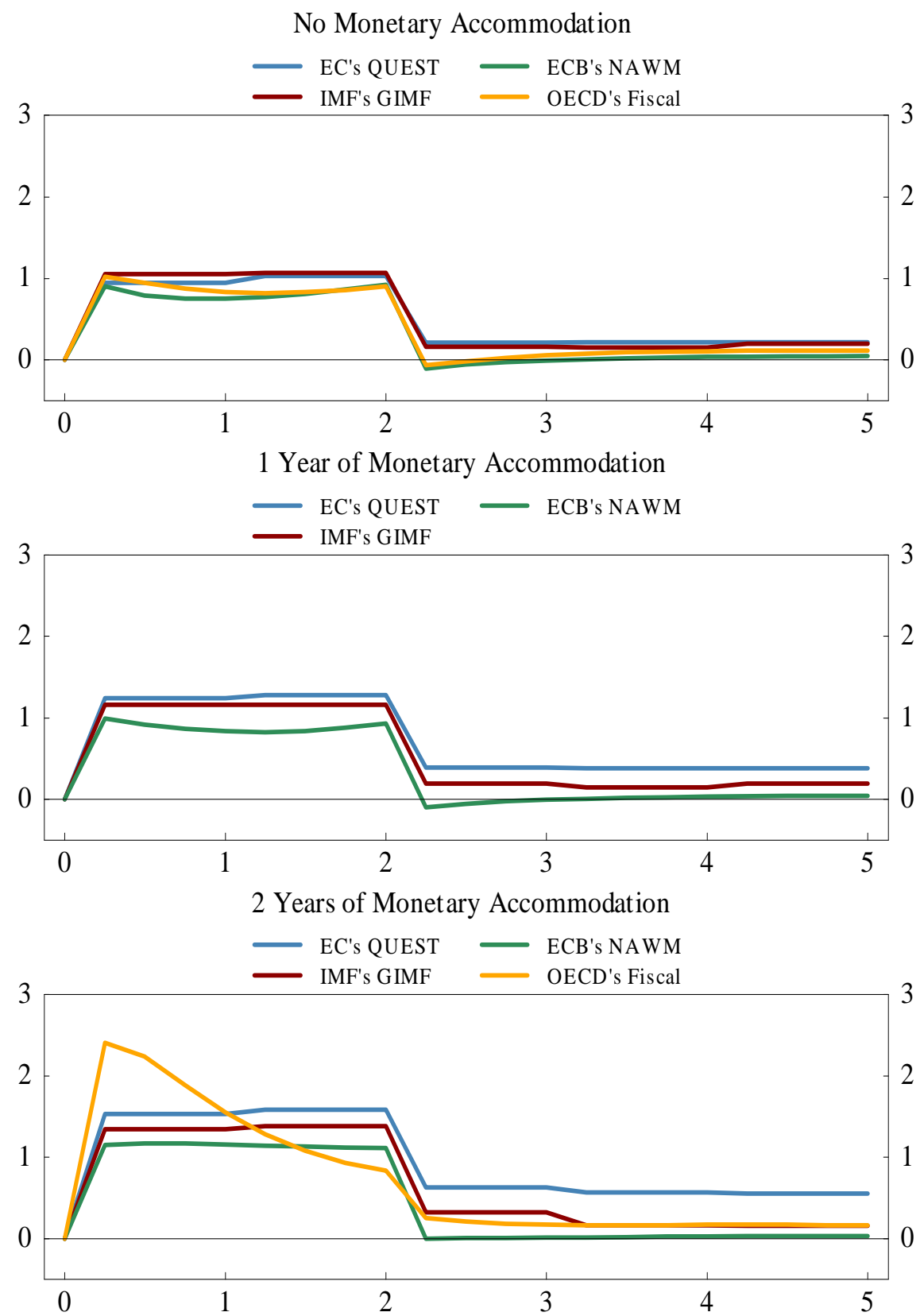
Figure 65. Euro Area / European Union: Effect of 2 Years of Fiscal Stimulus on Inflation and the Real Interest Rate (Instrument: Government Investment)

(In percentage points)

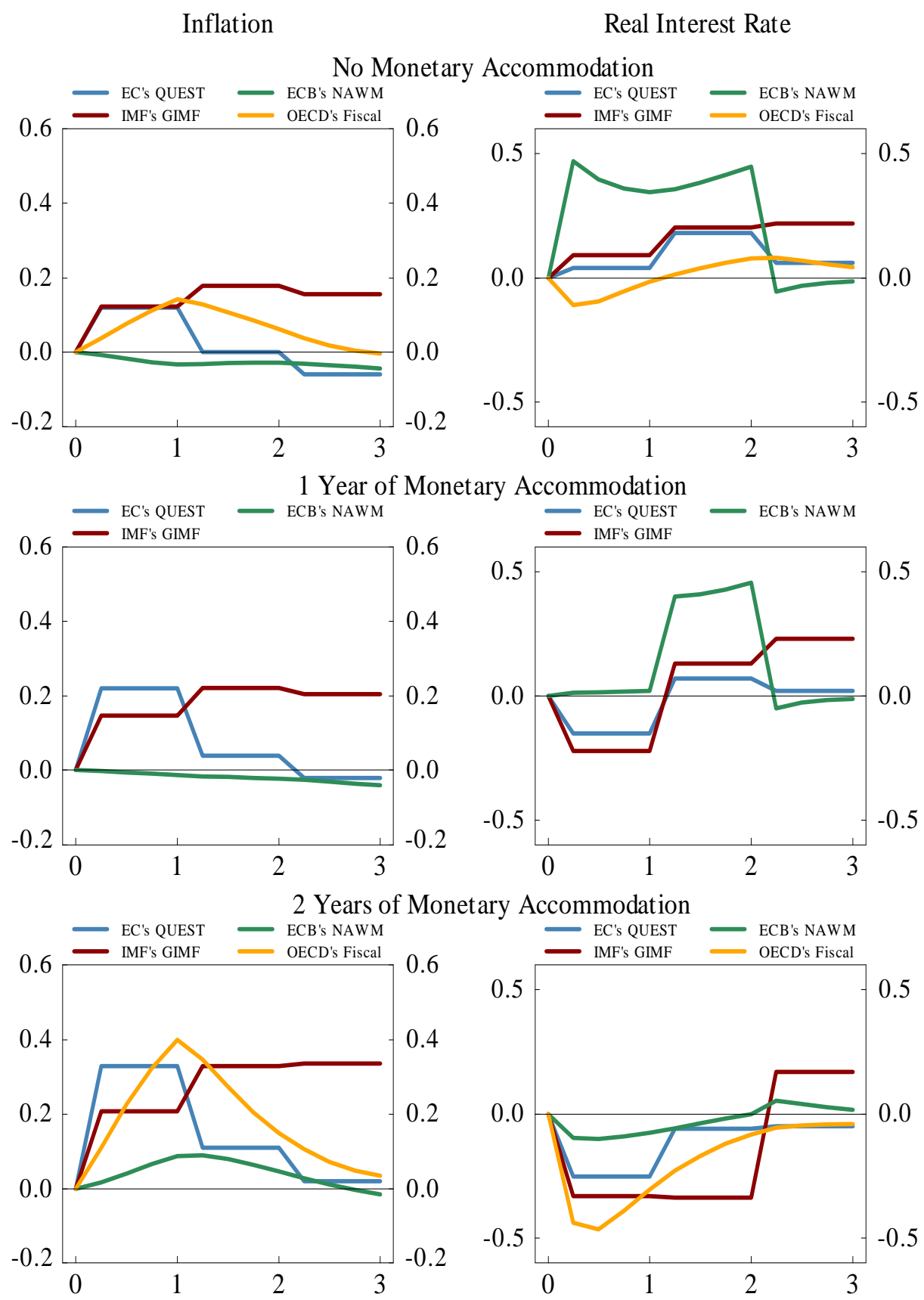


Figure 66. Euro Area / European Union: Effect of 2 Years of Fiscal Stimulus on Consumption and Investment (Instrument: Government Investment)

$$
\text { (In percent) }
$$

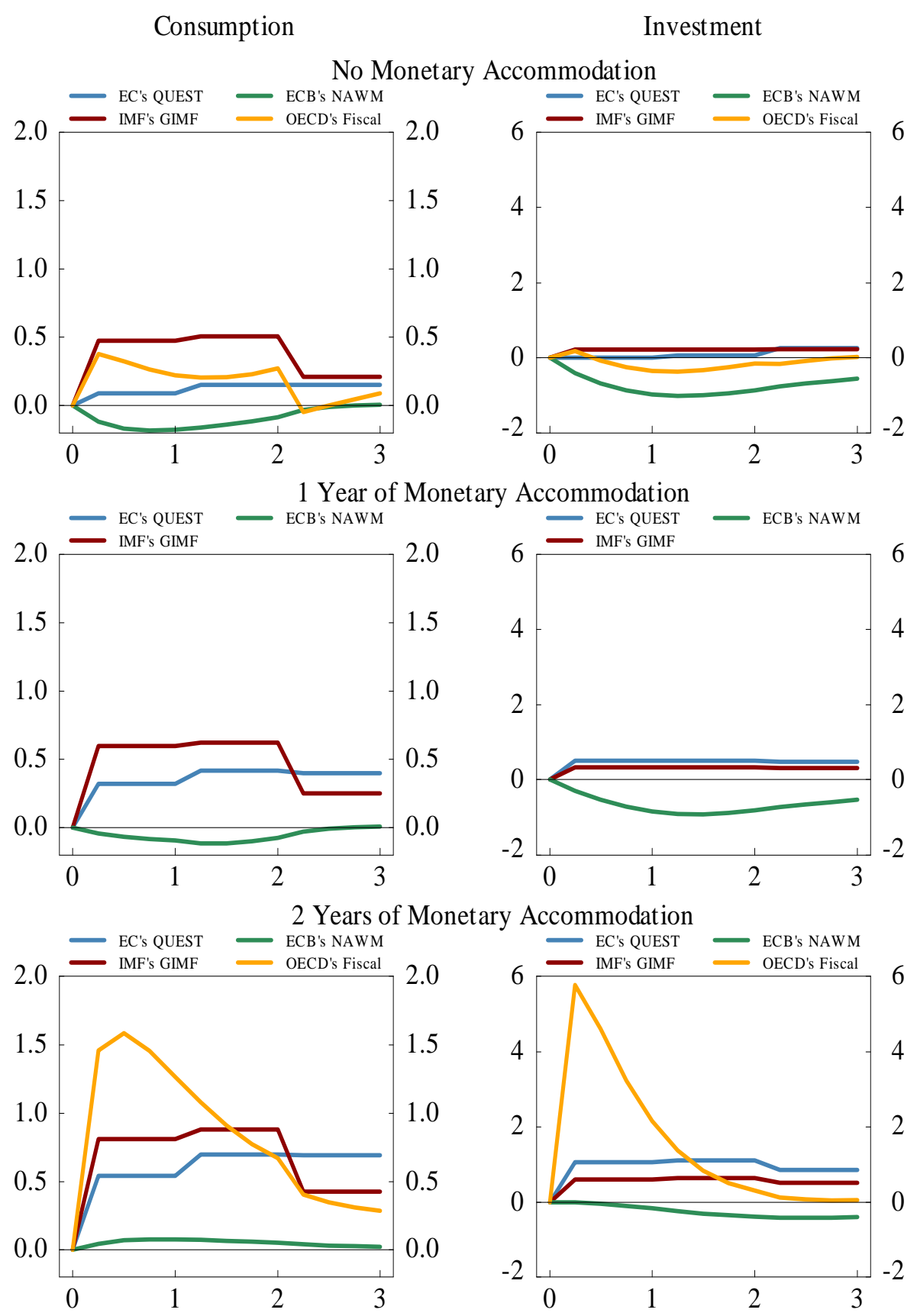


Figure 67. Euro Area / European Union: Effect of 2 Years of Fiscal Stimulus on Real GDP (Instrument: Government Consumption)

$$
\text { (In percent) }
$$
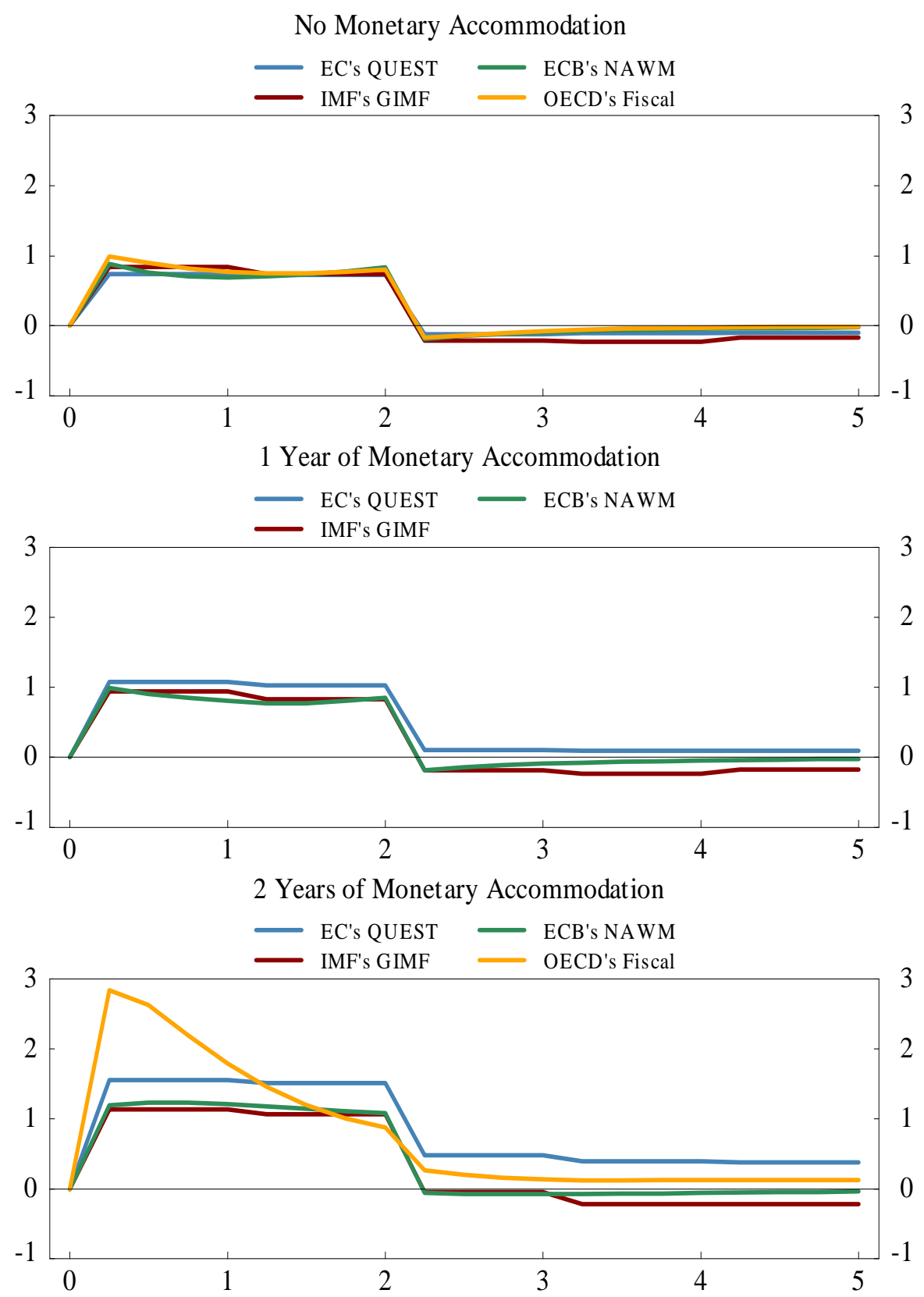
Figure 68. Euro Area / European Union: Effect of 2 Years of Fiscal Stimulus on Inflation and the Real Interest Rate (Instrument: Government Consumption)

(In percentage points)

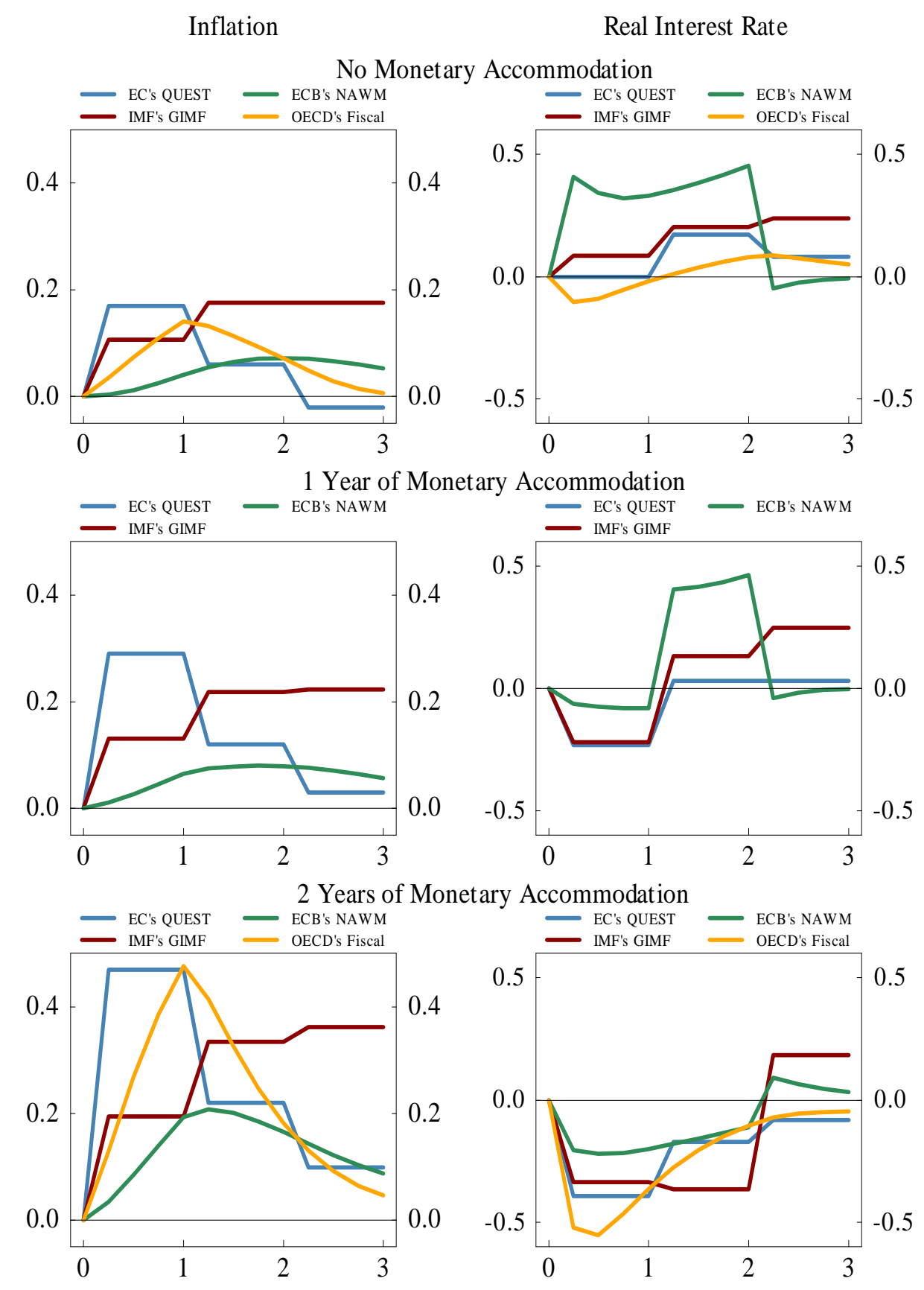


Figure 69. Euro Area / European Union: Effect of 2 Years of Fiscal Stimulus on Consumption and Investment (Instrument: Government Consumption)

$$
\text { (In percent) }
$$

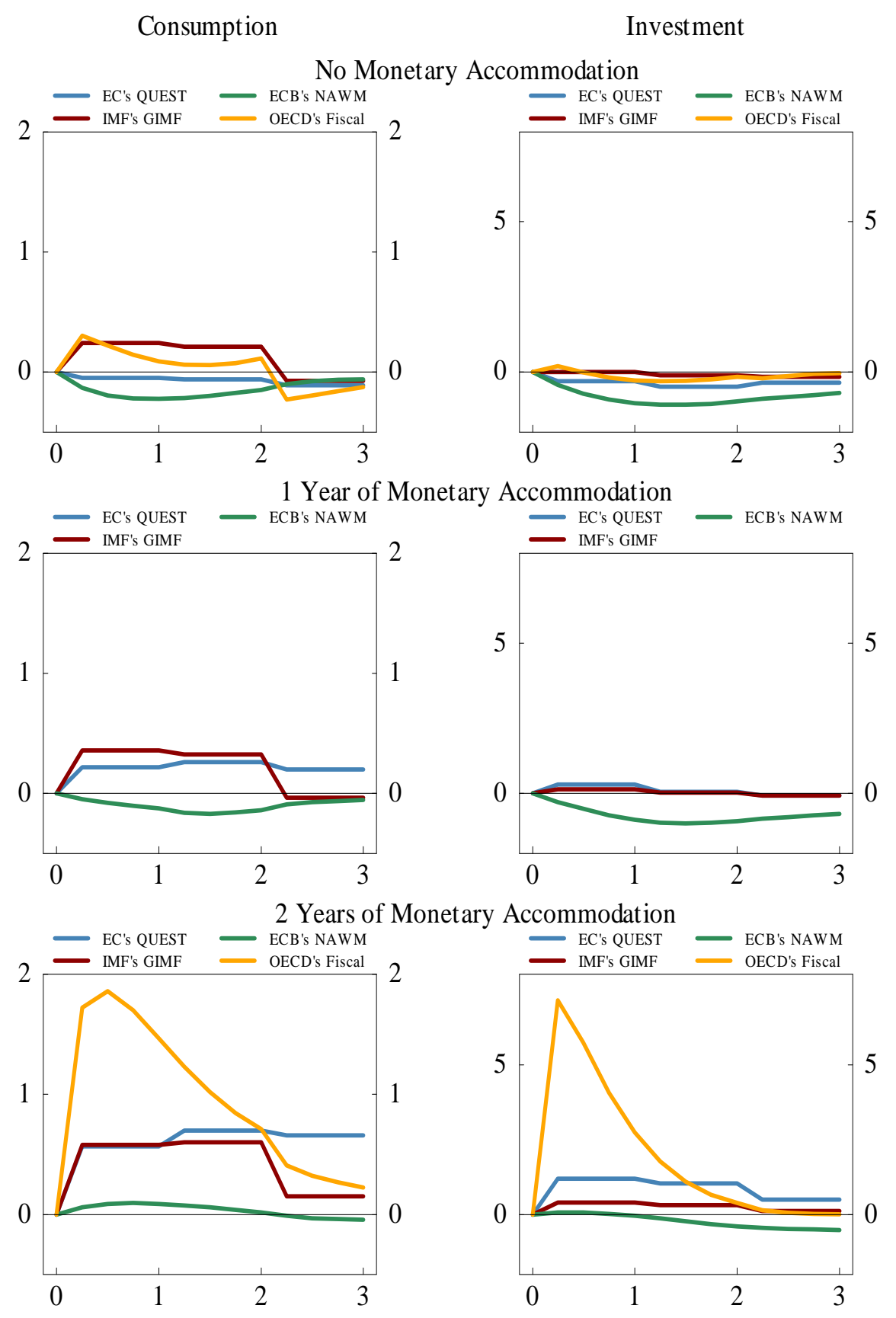


Figure 70. Euro Area / European Union: Effect of 2 Years of Fiscal Stimulus on Real GDP (Instrument: General Transfers)

$$
\text { (In percent) }
$$
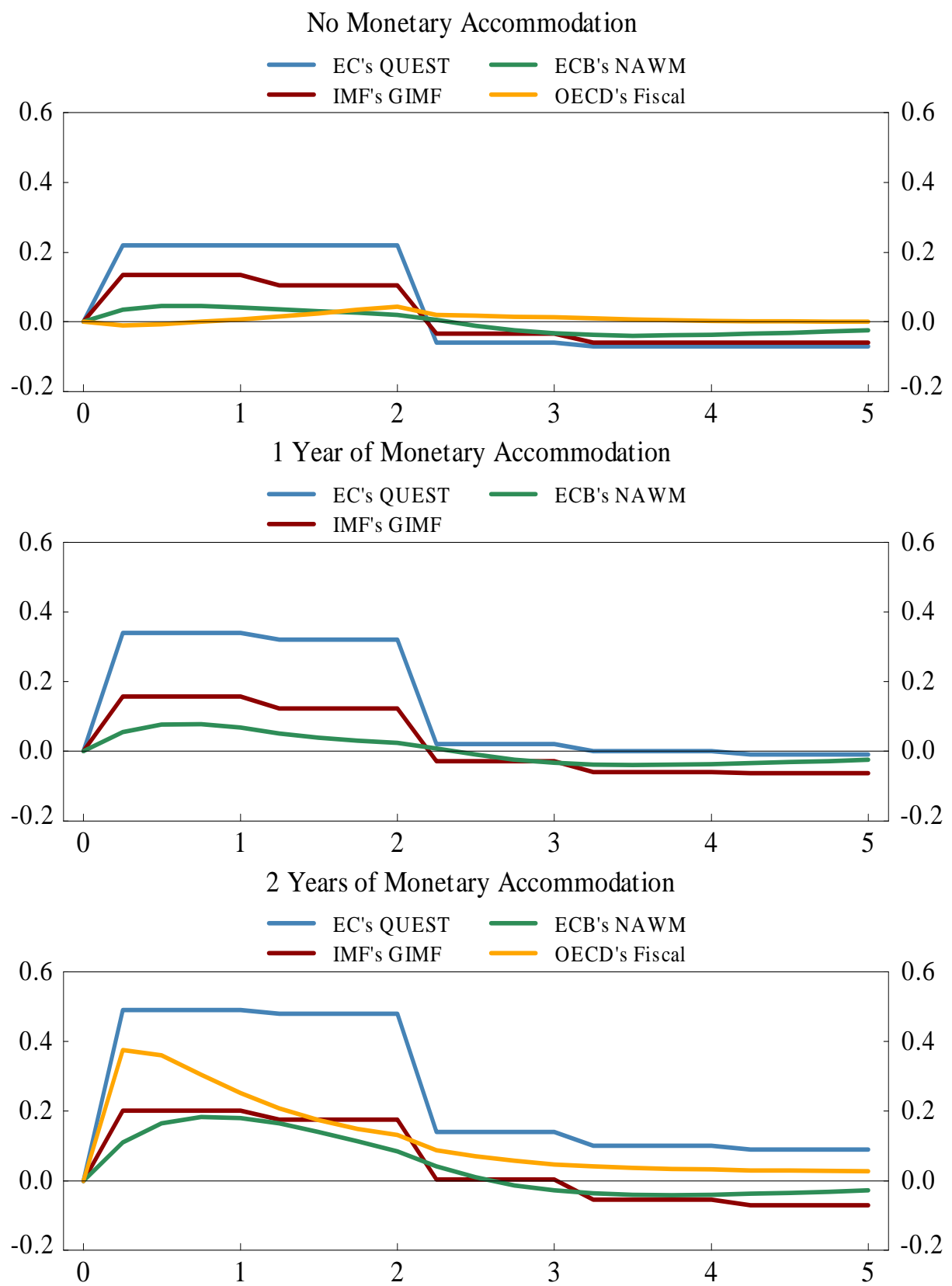
Figure 71. Euro Area / European Union: Effect of 2 Years of Fiscal Stimulus on Inflation and the Real Interest Rate (Instrument: General Transfers)

(In percentage points)

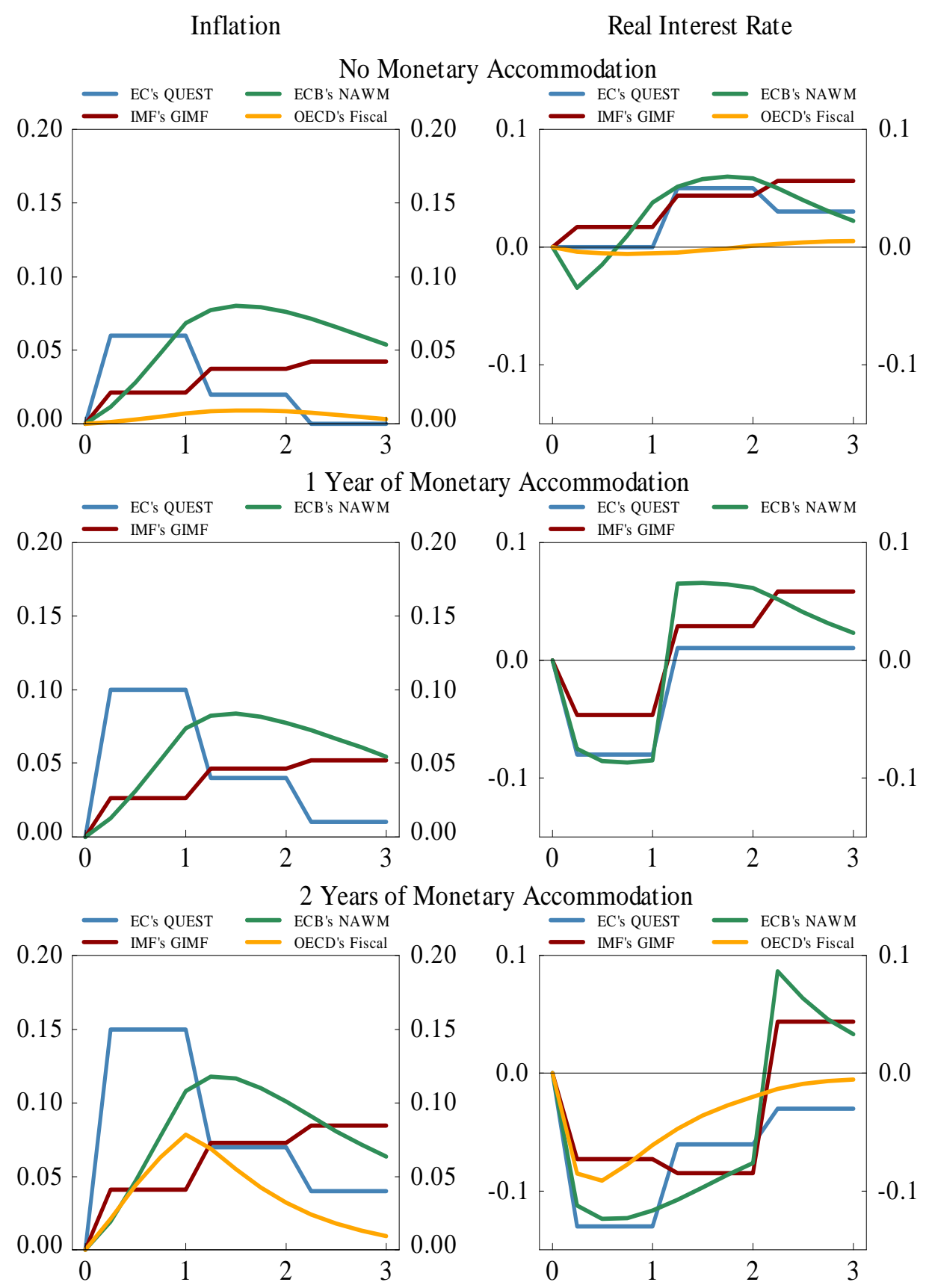


Figure 72. Euro Area / European Union: Effect of 2 Years of Fiscal Stimulus on Consumption and Investment (Instrument: General Transfers)

$$
\text { (In percent) }
$$

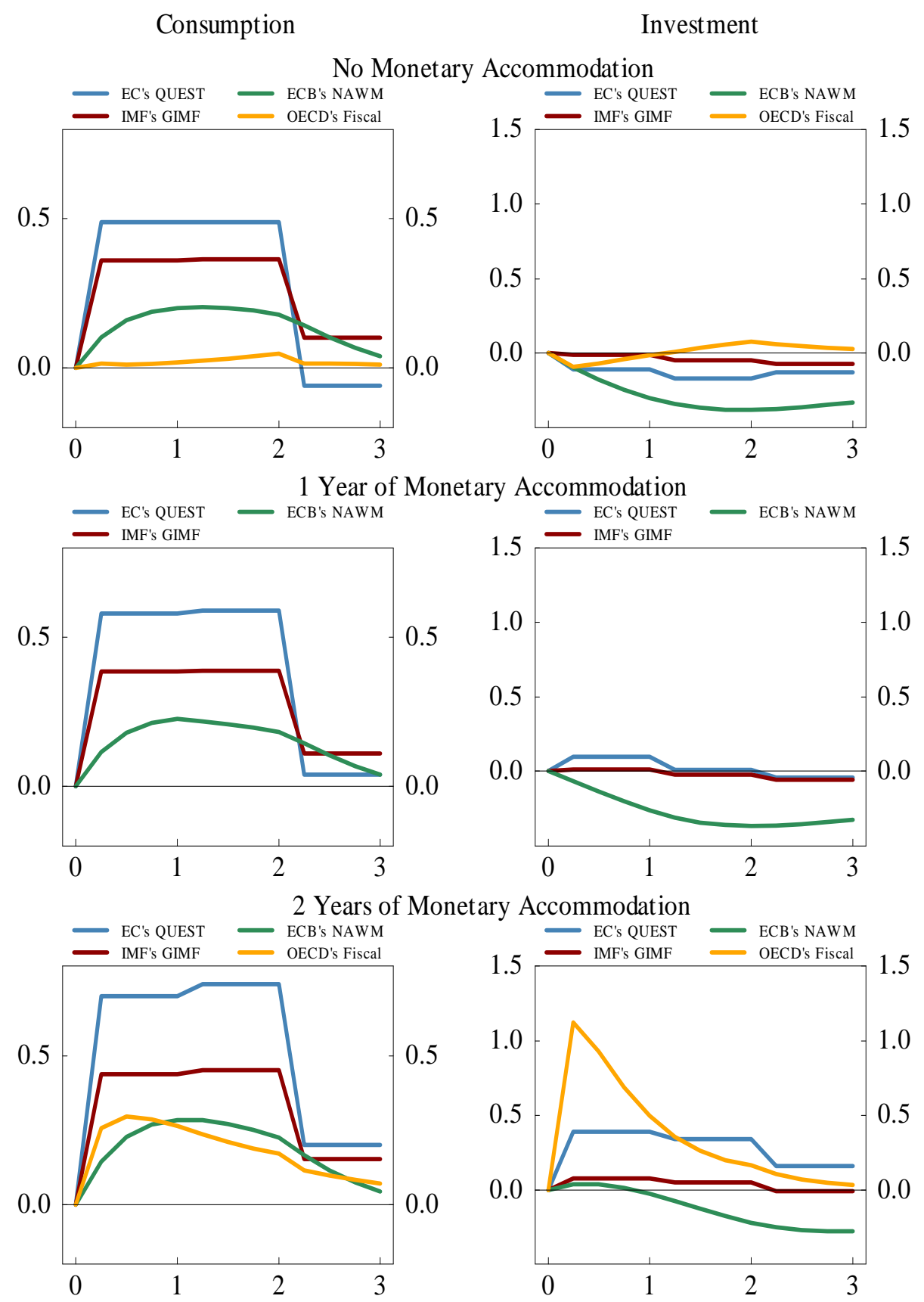


Figure 73. Euro Area / European Union: Effect of 2 Years of Fiscal Stimulus on Real GDP (Instrument: Targeted Transfers)

$$
\text { (In percent) }
$$
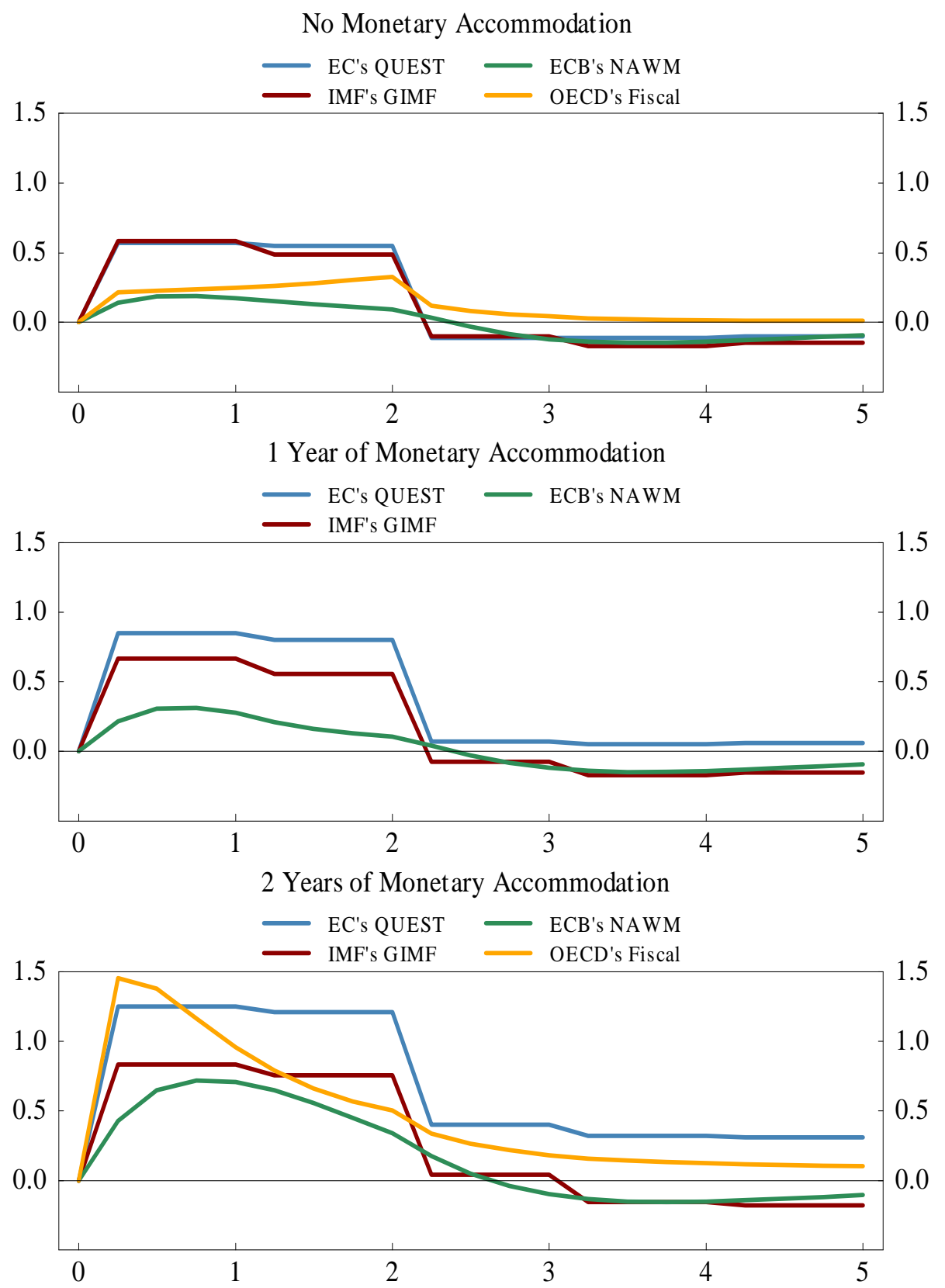
Figure 74. Euro Area / European Union: Effect of 2 Years of Fiscal Stimulus on Inflation and the Real Interest Rate (Instrument: Targeted Transfers)

(In percentage points)
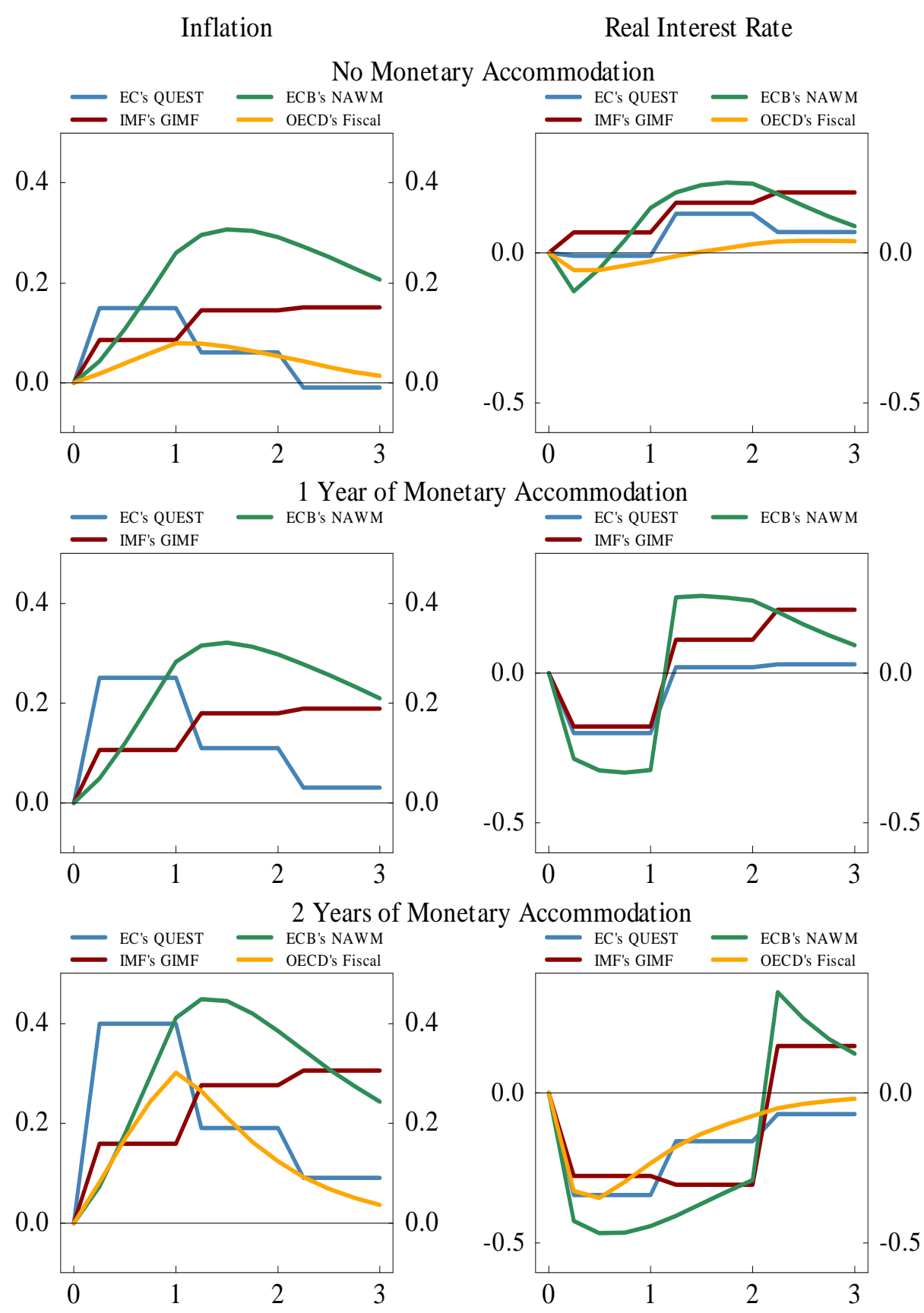
Figure 75. Euro Area / European Union: Effect of 2 Years of Fiscal Stimulus on Consumption and Investment (Instrument: Targeted Transfers)

$$
\text { (In percent) }
$$

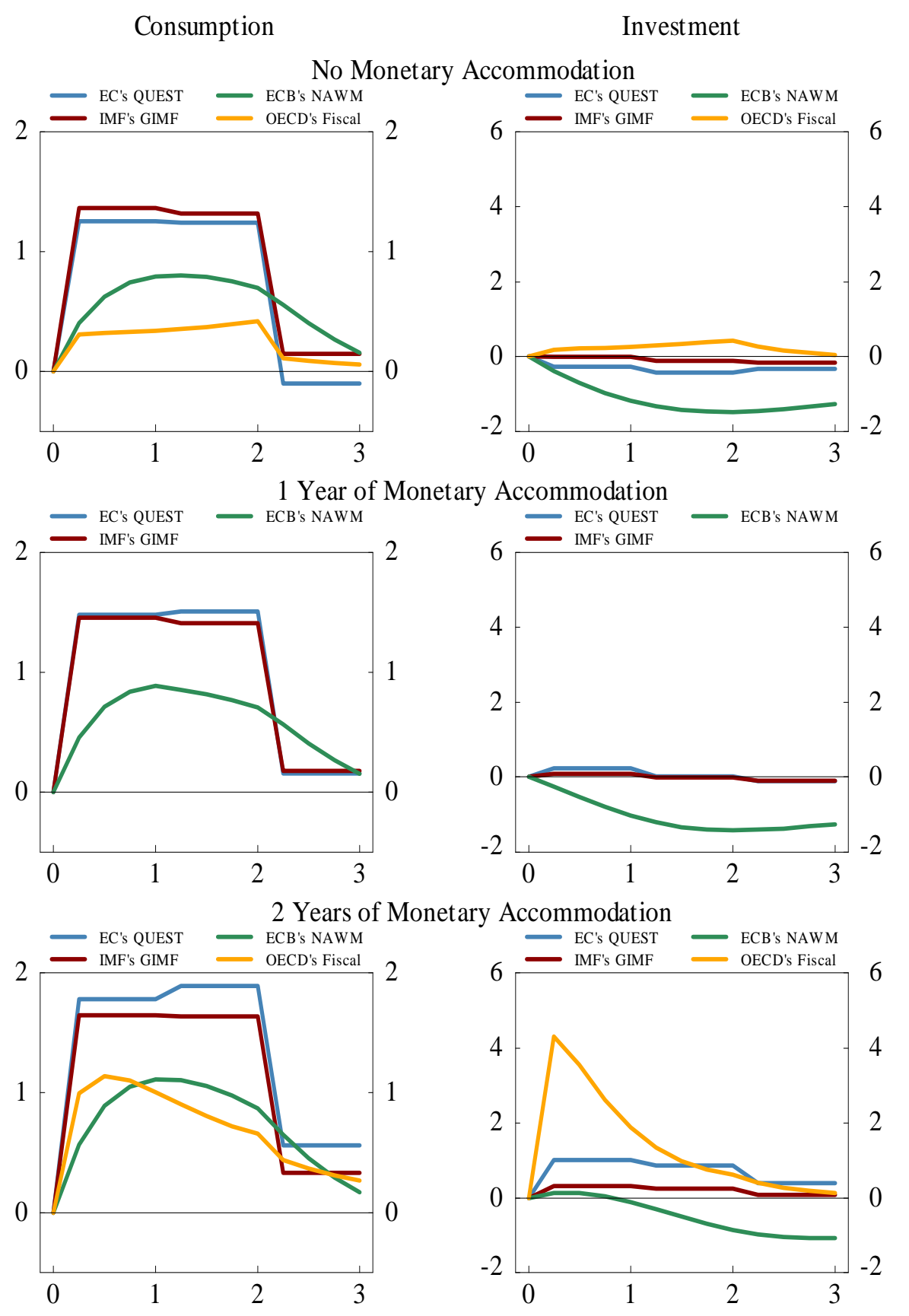


Figure 76. Euro Area / European Union: Effect of 2 Years of Fiscal Stimulus on Real GDP (Instrument: Labor Income Tax)

$$
\text { (In percent) }
$$
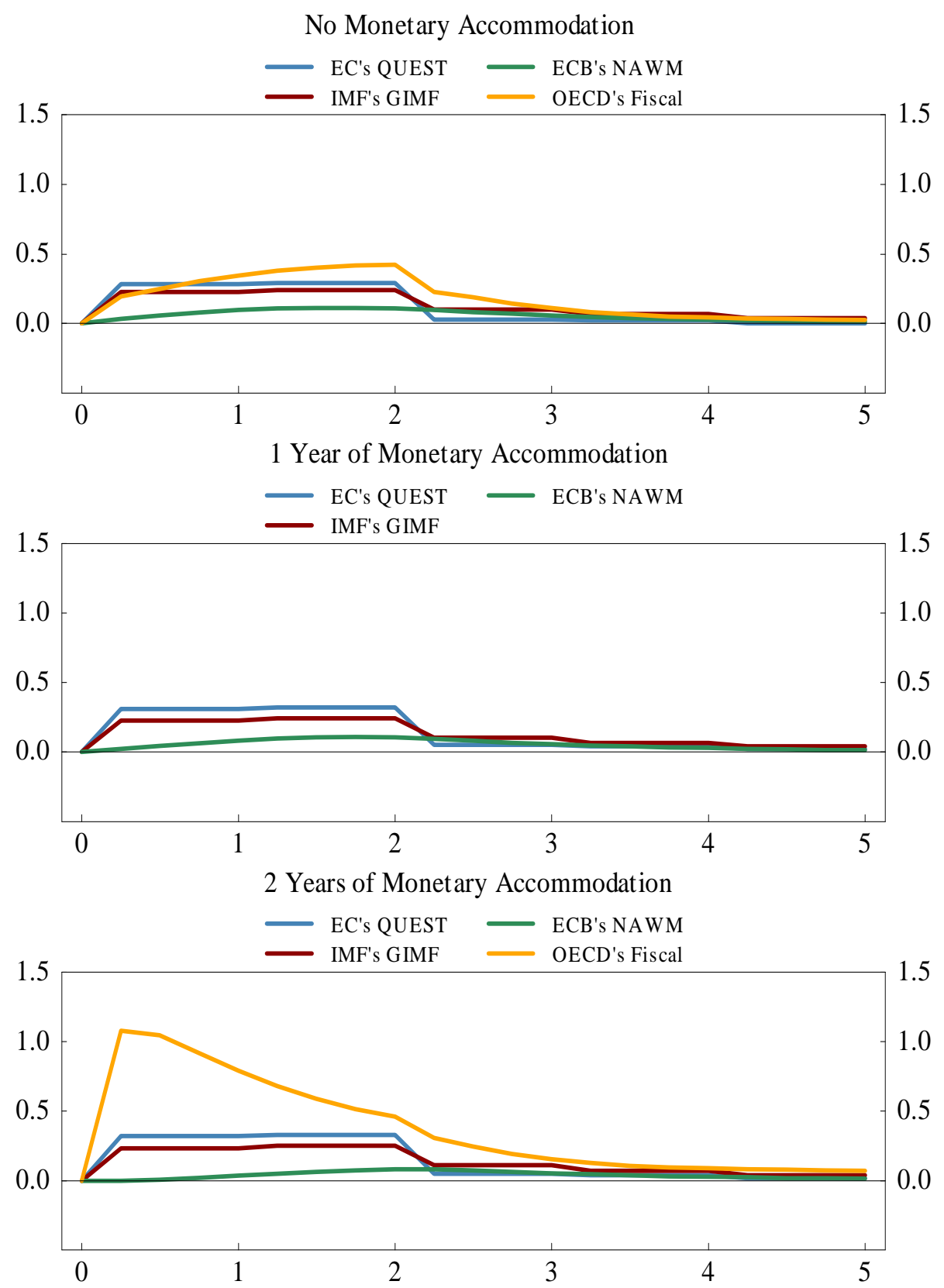
Figure 77. Euro Area / European Union: Effect of 2 Years of Fiscal Stimulus on Inflation and the Real Interest Rate (Instrument: Labor Income Tax)

(In percentage points)

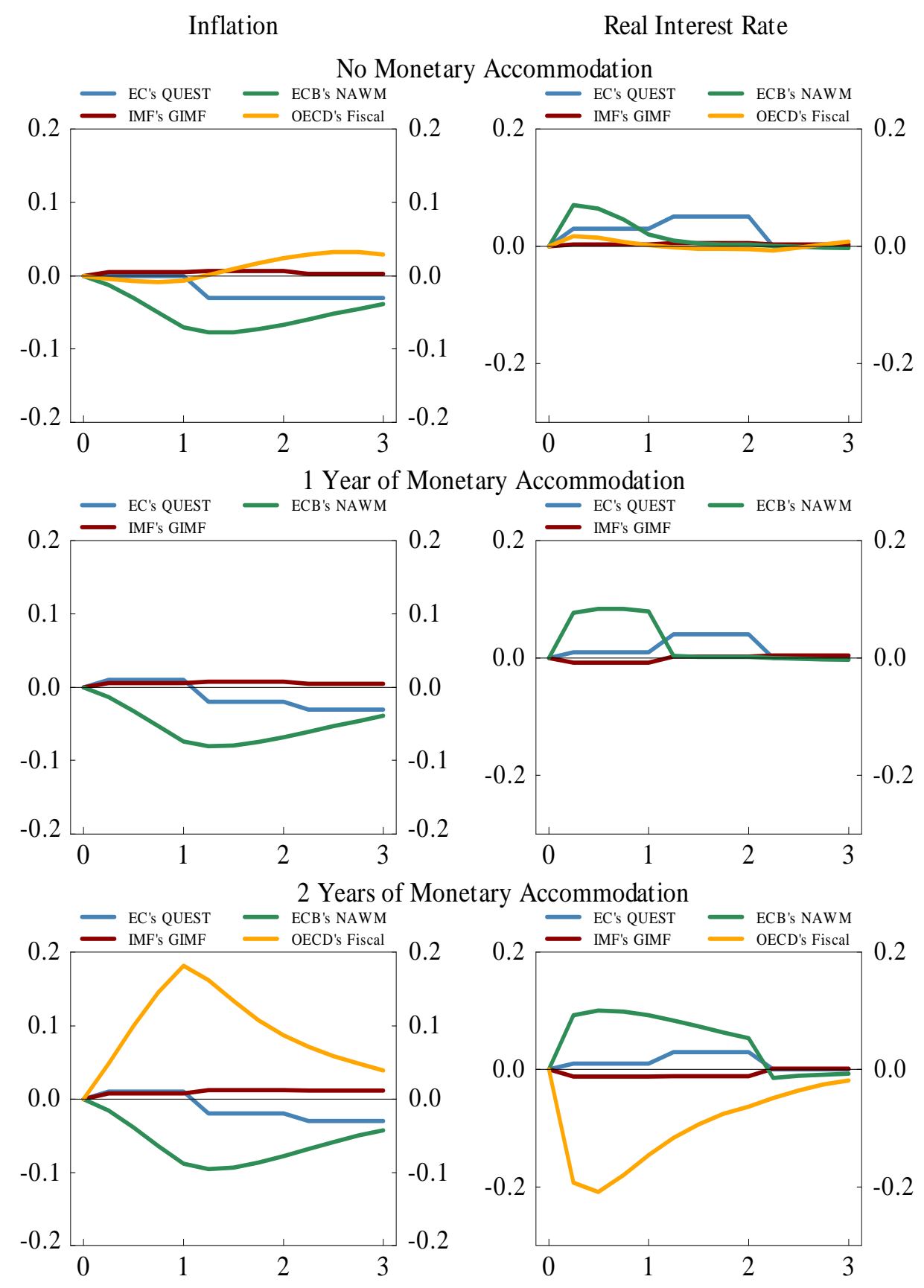


Figure 78. Euro Area / European Union: Effect of 2 Years of Fiscal Stimulus on Consumption and Investment (Instrument: Labor Income Tax)

$$
\text { (In percent) }
$$

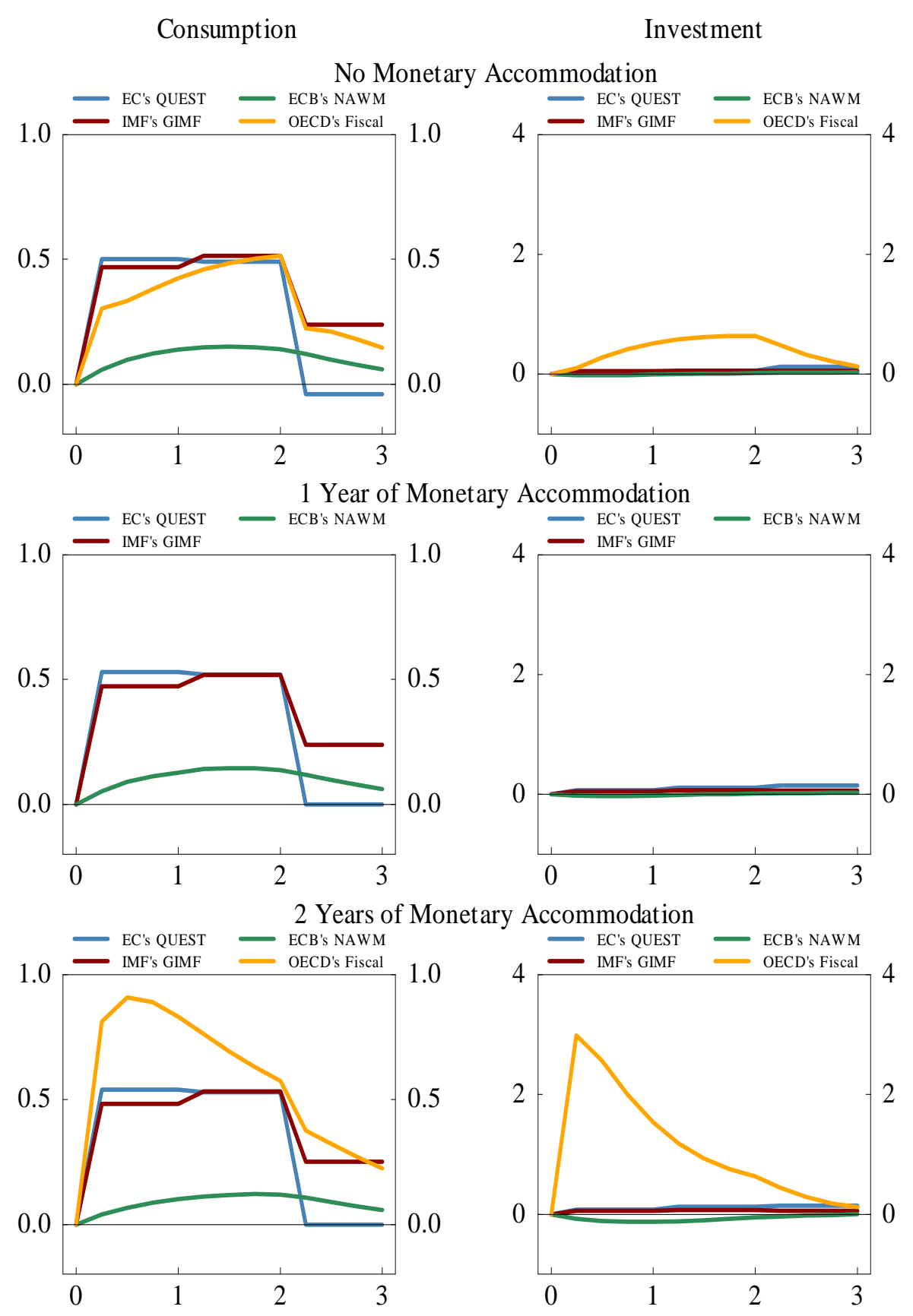


Figure 79. Euro Area / European Union: Effect of 2 Years of Fiscal Stimulus on Real GDP (Instrument: Consumption Tax)

$$
\text { (In percent) }
$$
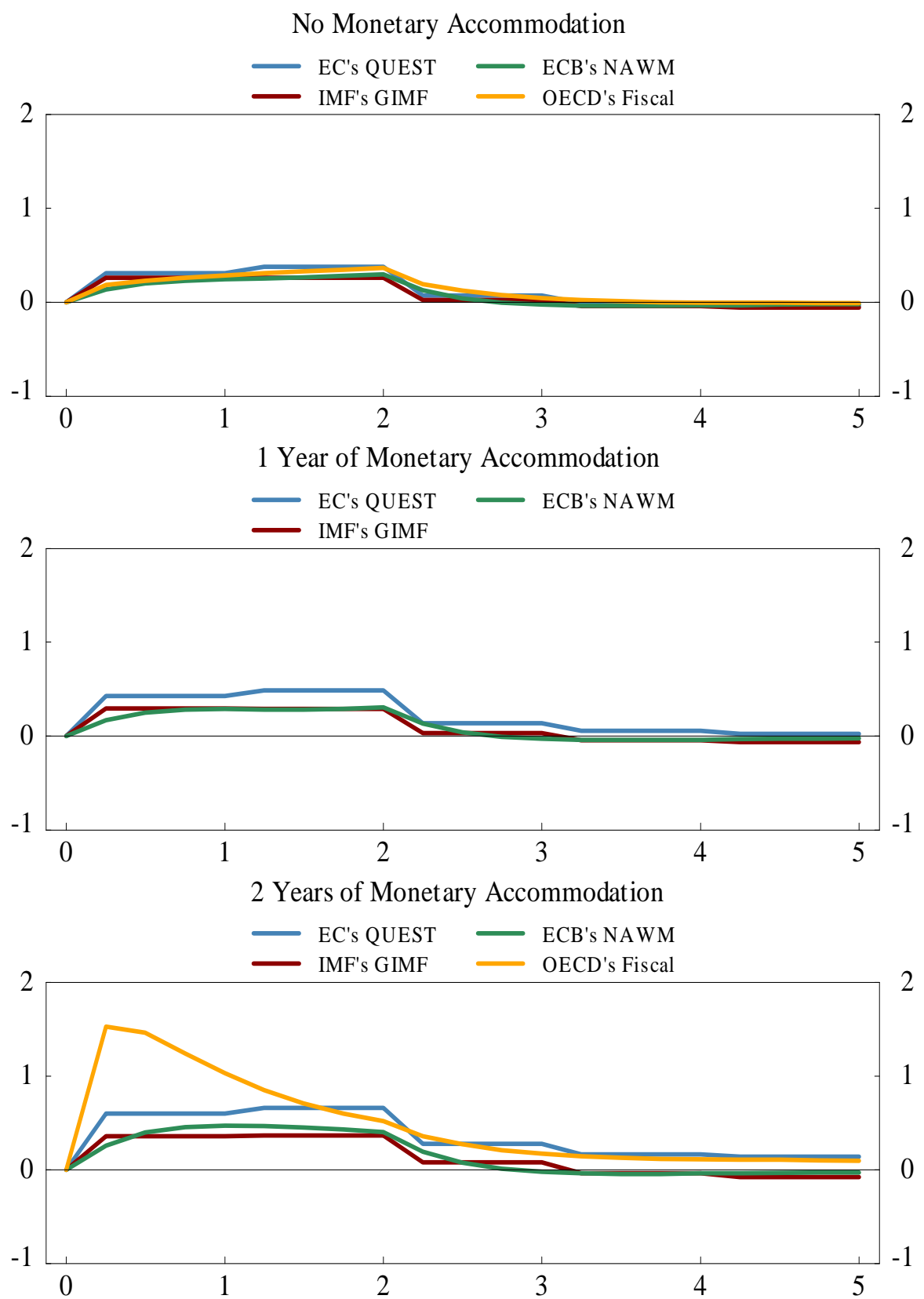
Figure 80. Euro Area / European Union: Effect of 2 Years of Fiscal Stimulus on Inflation and the Real Interest Rate (Instrument: Consumption Tax)

(In percentage points)

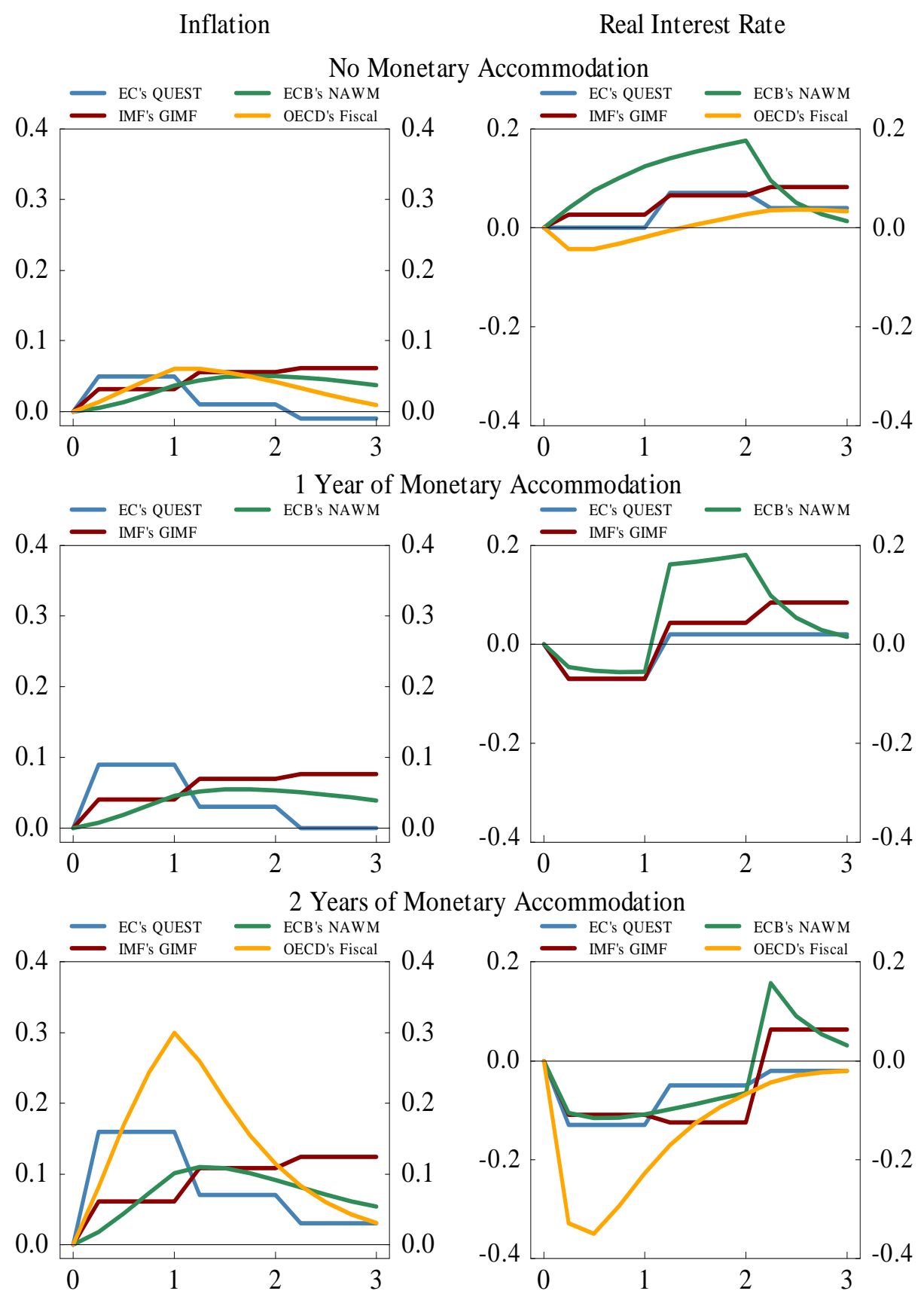


Figure 81. Euro Area / European Union: Effect of 2 Years of Fiscal Stimulus on Consumption and Investment (Instrument: Consumption Tax)

$$
\text { (In percent) }
$$

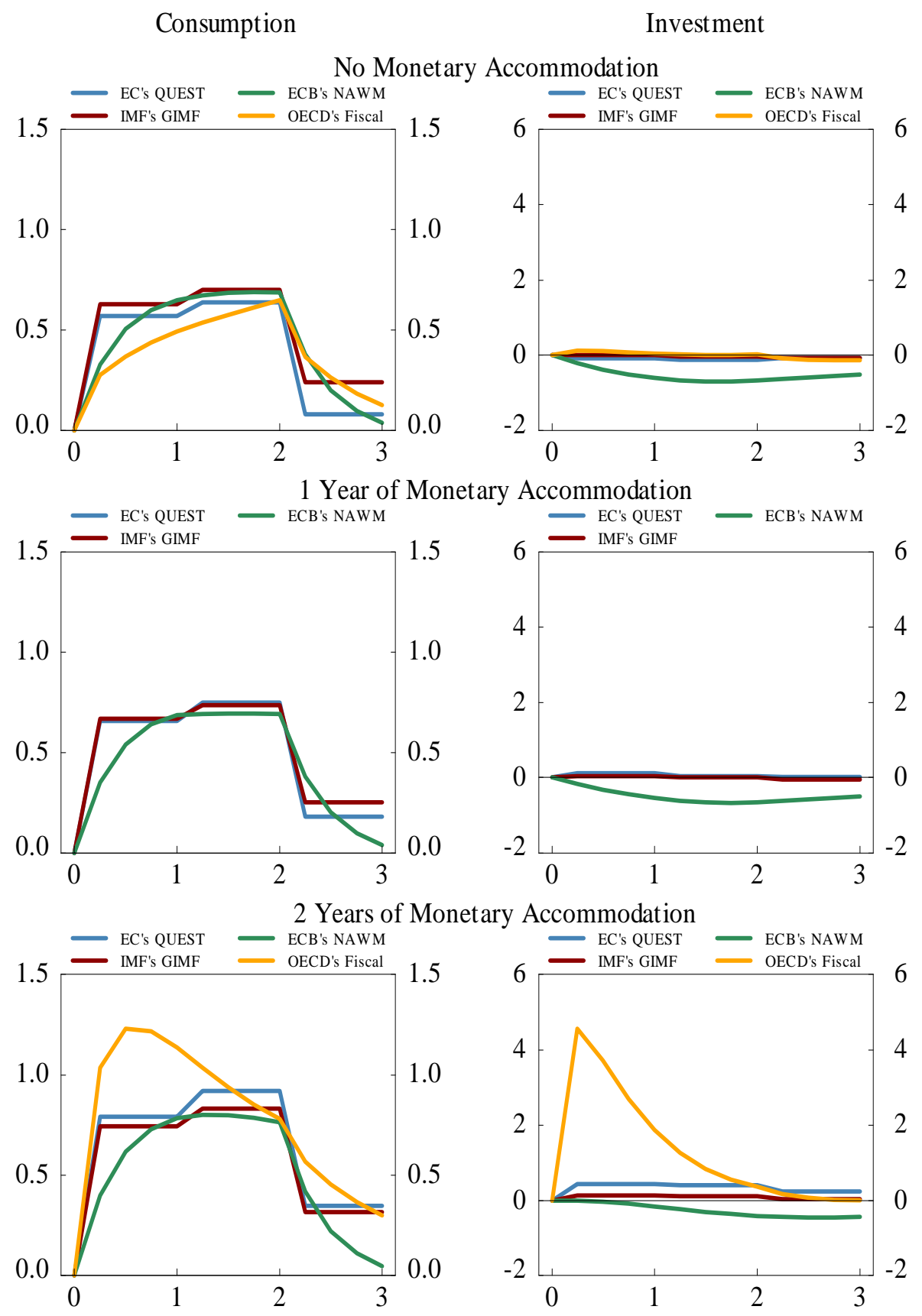


Figure 82. Euro Area / European Union: Effect of 2 Years of Fiscal Stimulus on Real GDP (Instrument: Corporate Income Tax)

$$
\text { (In percent) }
$$
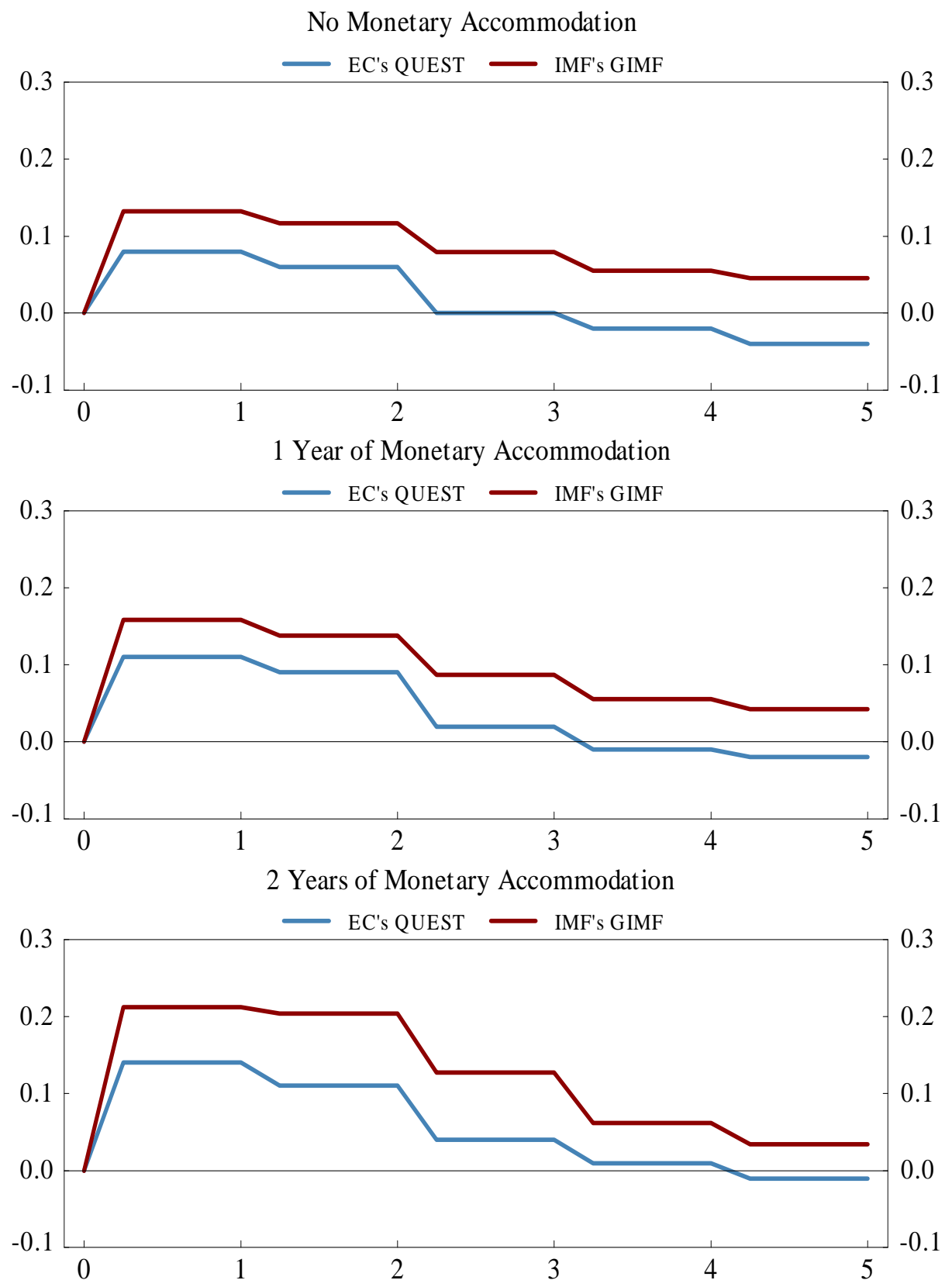
Figure 83. Euro Area / European Union: Effect of 2 Years of Fiscal Stimulus on Inflation and the Real Interest Rate (Instrument: Corporate Income Tax)

(In percentage points)

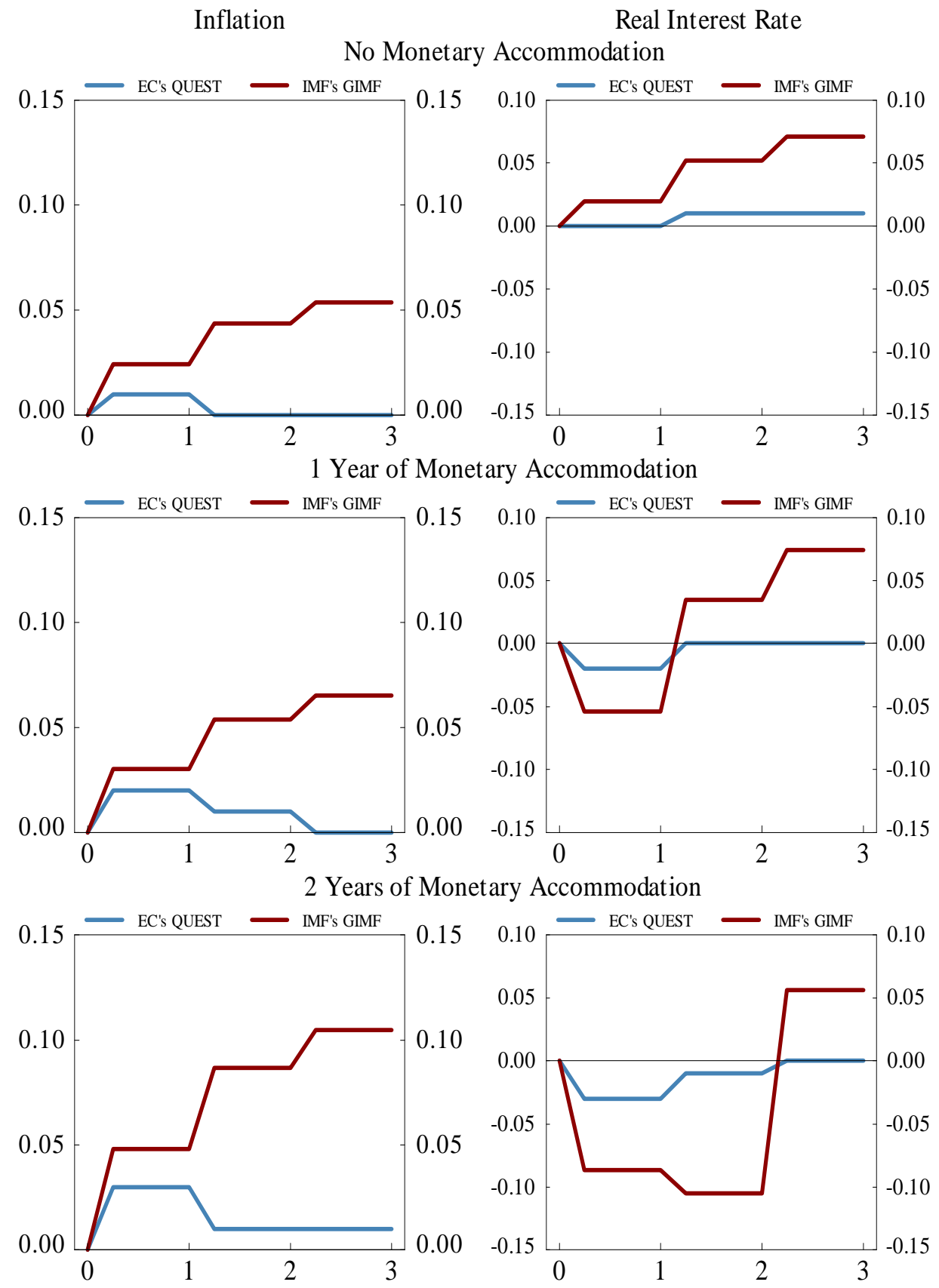


Figure 84. Euro Area / European Union: Effect of 2 Years of Fiscal Stimulus on Consumption and Investment (Instrument: Corporate Income Tax)

(In percent)

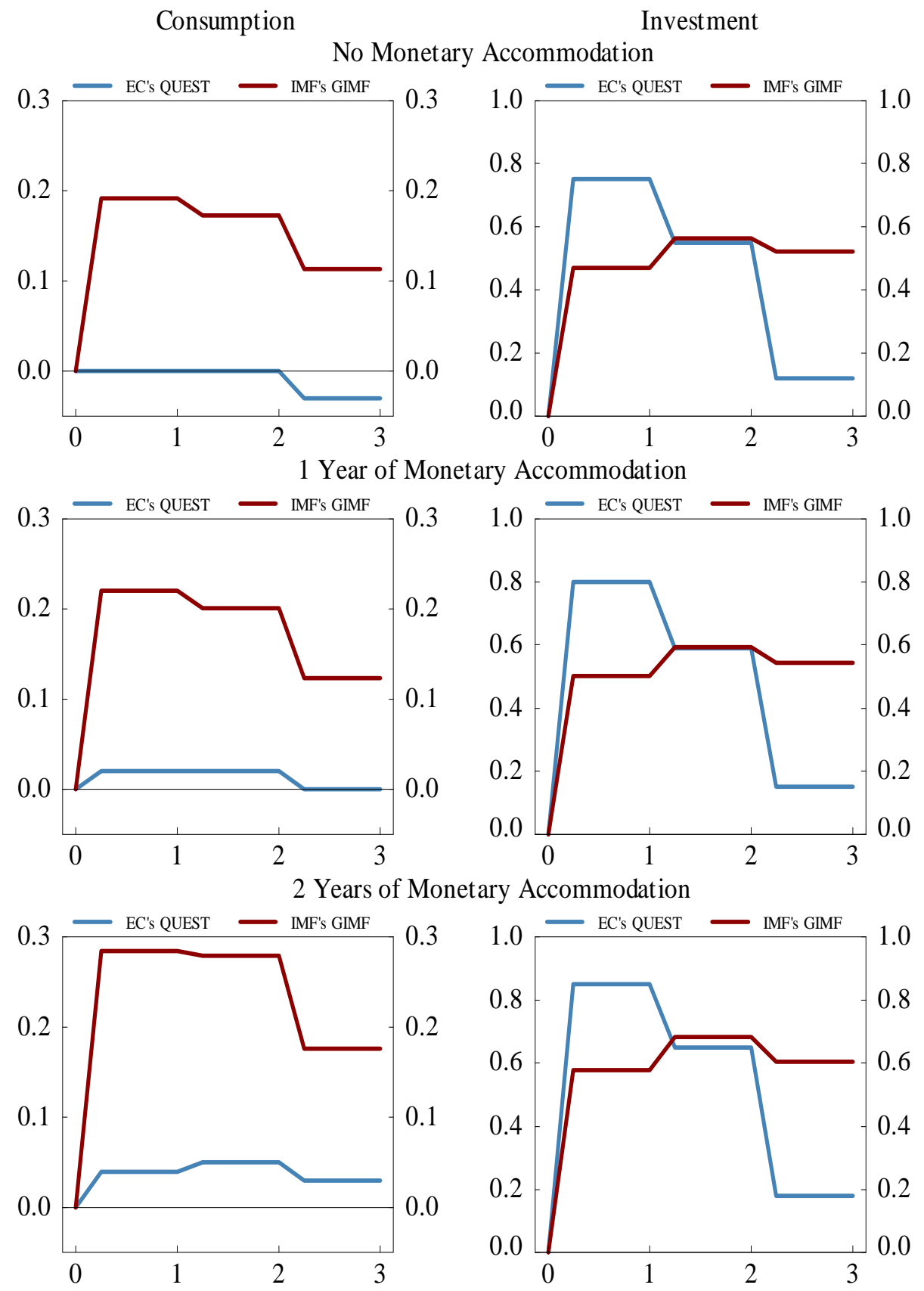


Figure 85. Effect of 2 Years of Fiscal Stimulus on Real GDP (Instrument: Government Investment)

\section{Years of Monetary Accommodation}

(In percent)

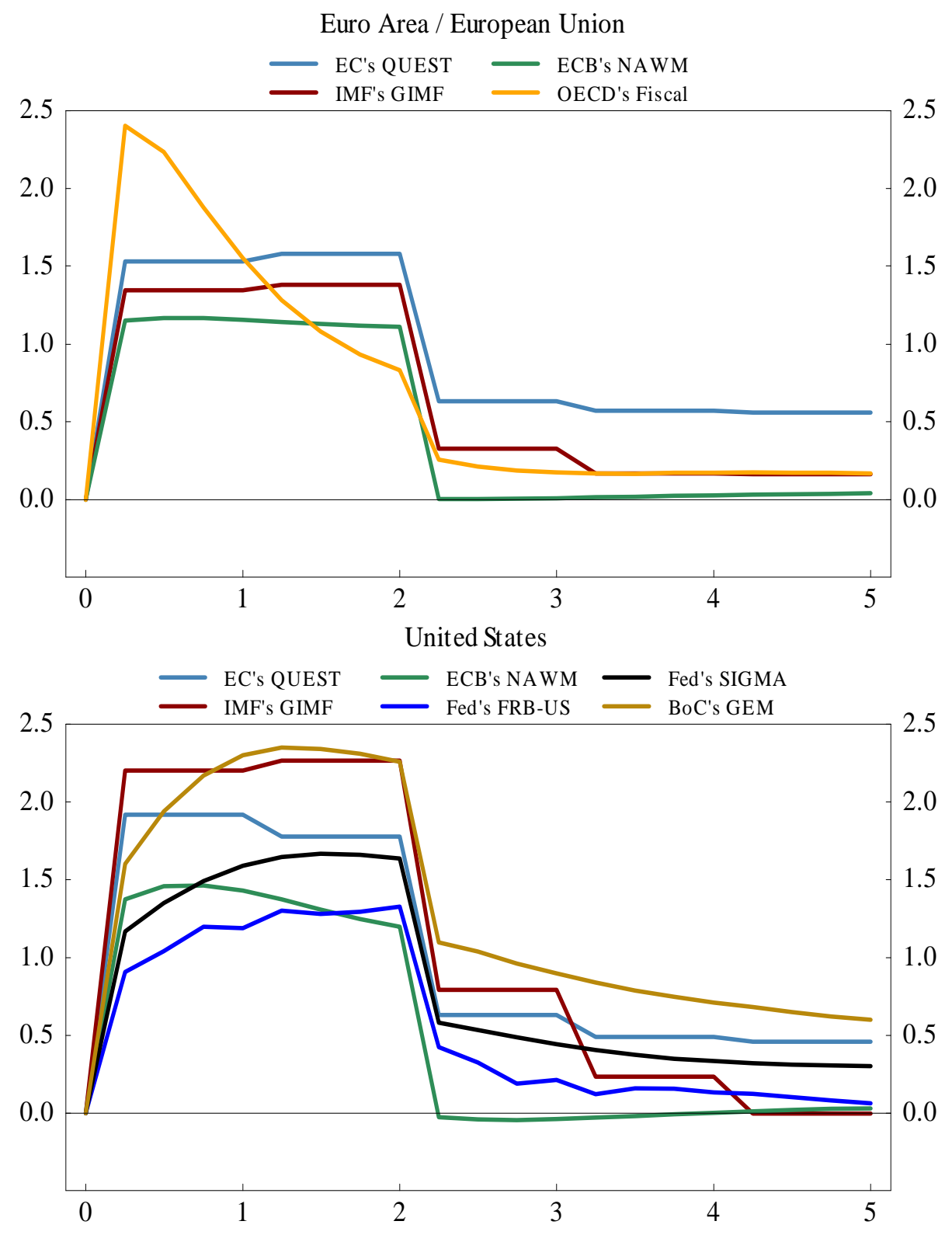


Figure 86. Effect of 2 Years of Fiscal Stimulus on Inflation and the Real Interest Rate (Instrument: Government Investment)

2 Years of Monetary Accommodation (In percentage points)

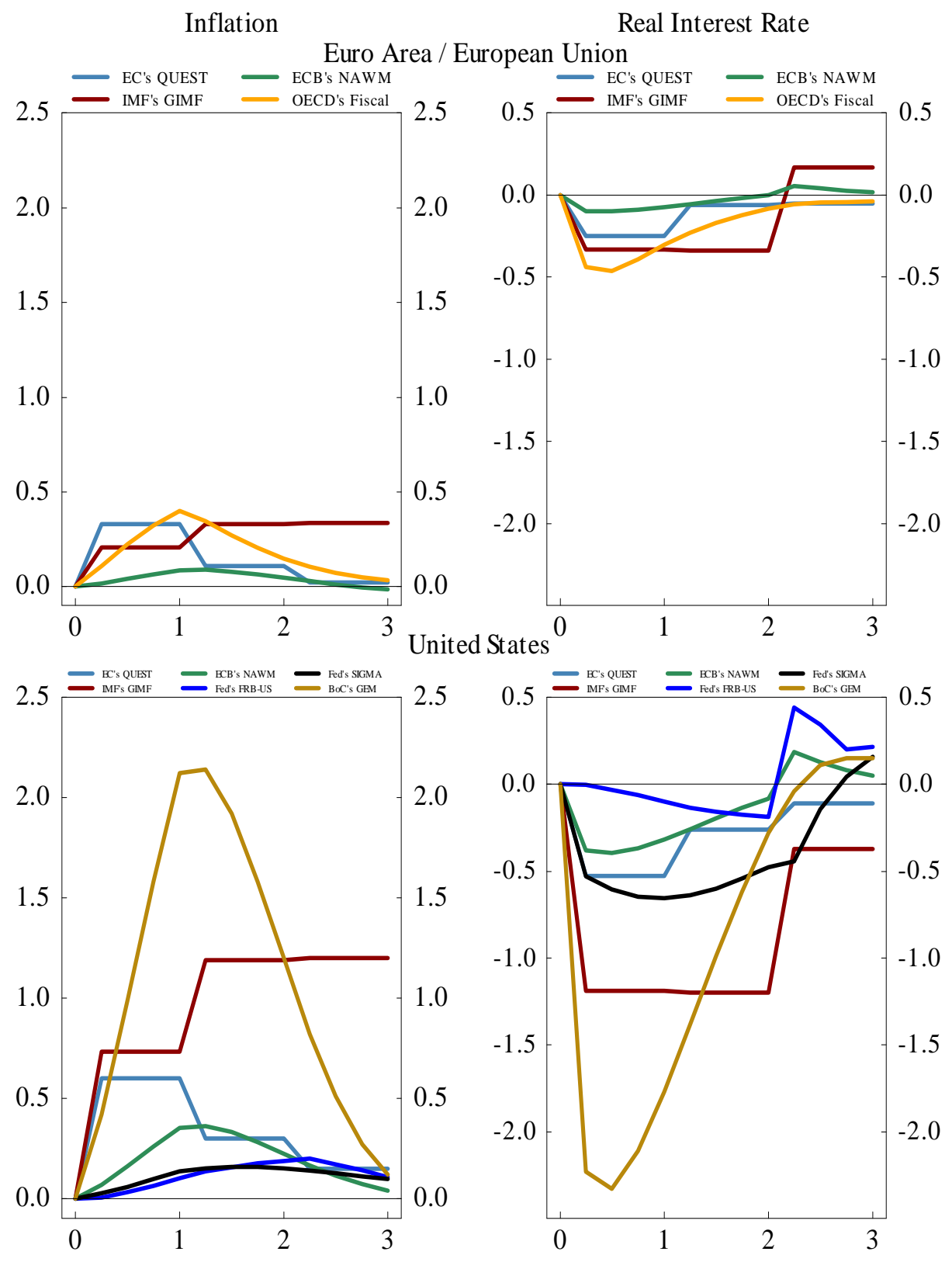


Figure 87. Effect of 2 Years of Fiscal Stimulus on Consumption and Investment (Instrument: Government Investment)

$$
\begin{aligned}
& 2 \text { Years of Monetary Accommodation } \\
& \text { (In percent) }
\end{aligned}
$$

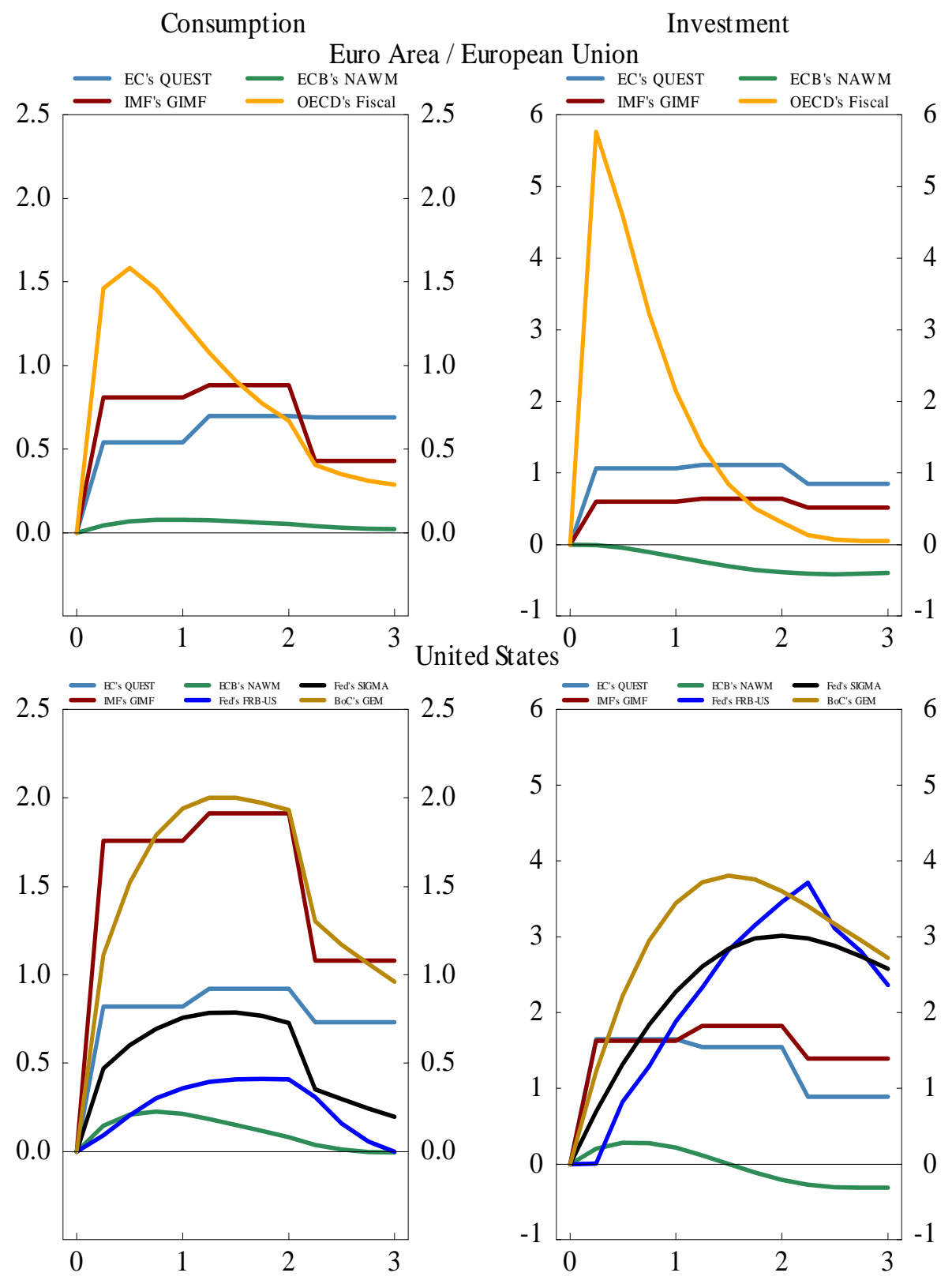


Figure 88. Effects of Openness on Short-Run Multipliers
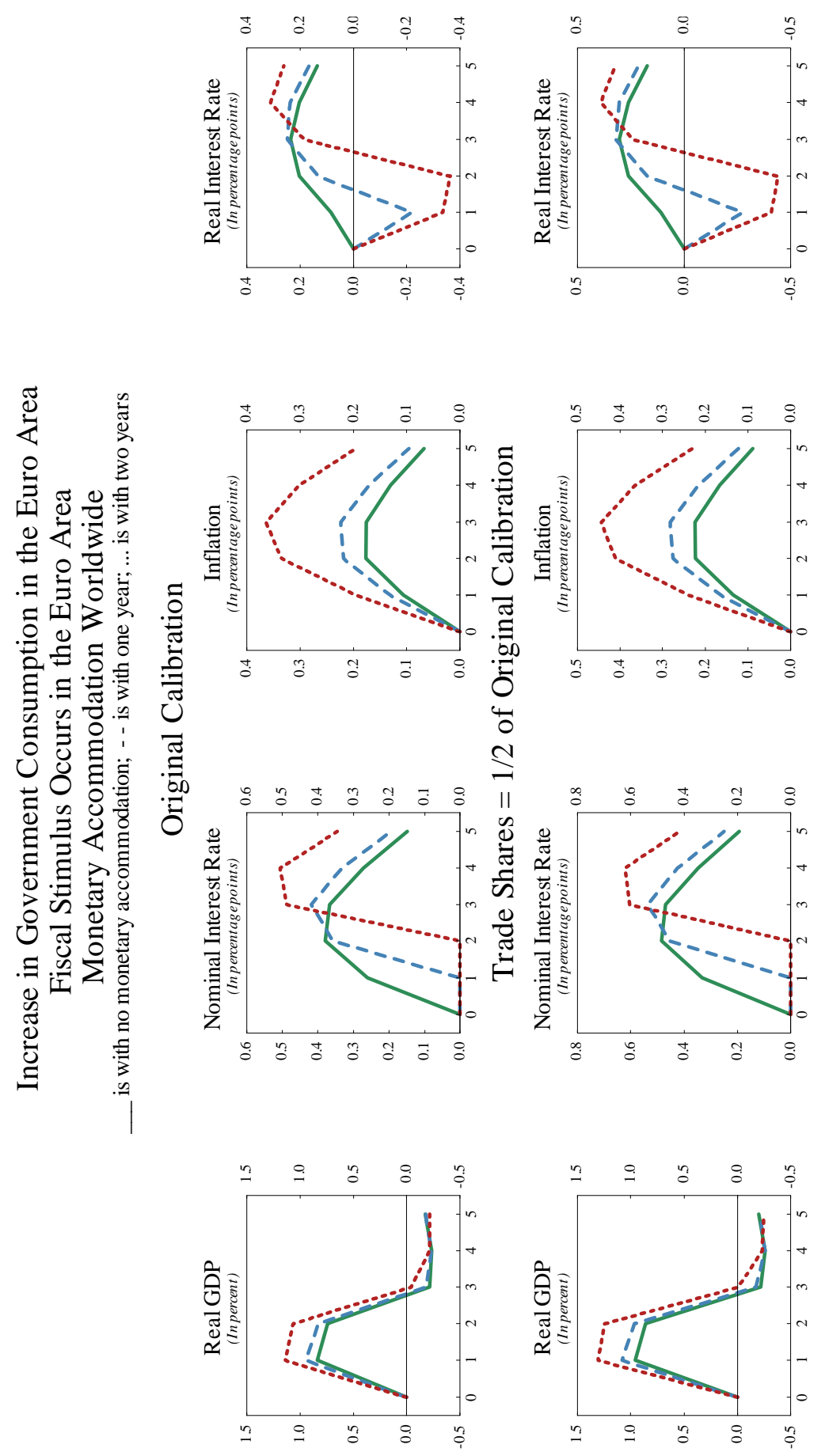
Figure 89. Effects of Nominal Rigidities and Automatic Stabilizers on Short-Run Fiscal Multipliers
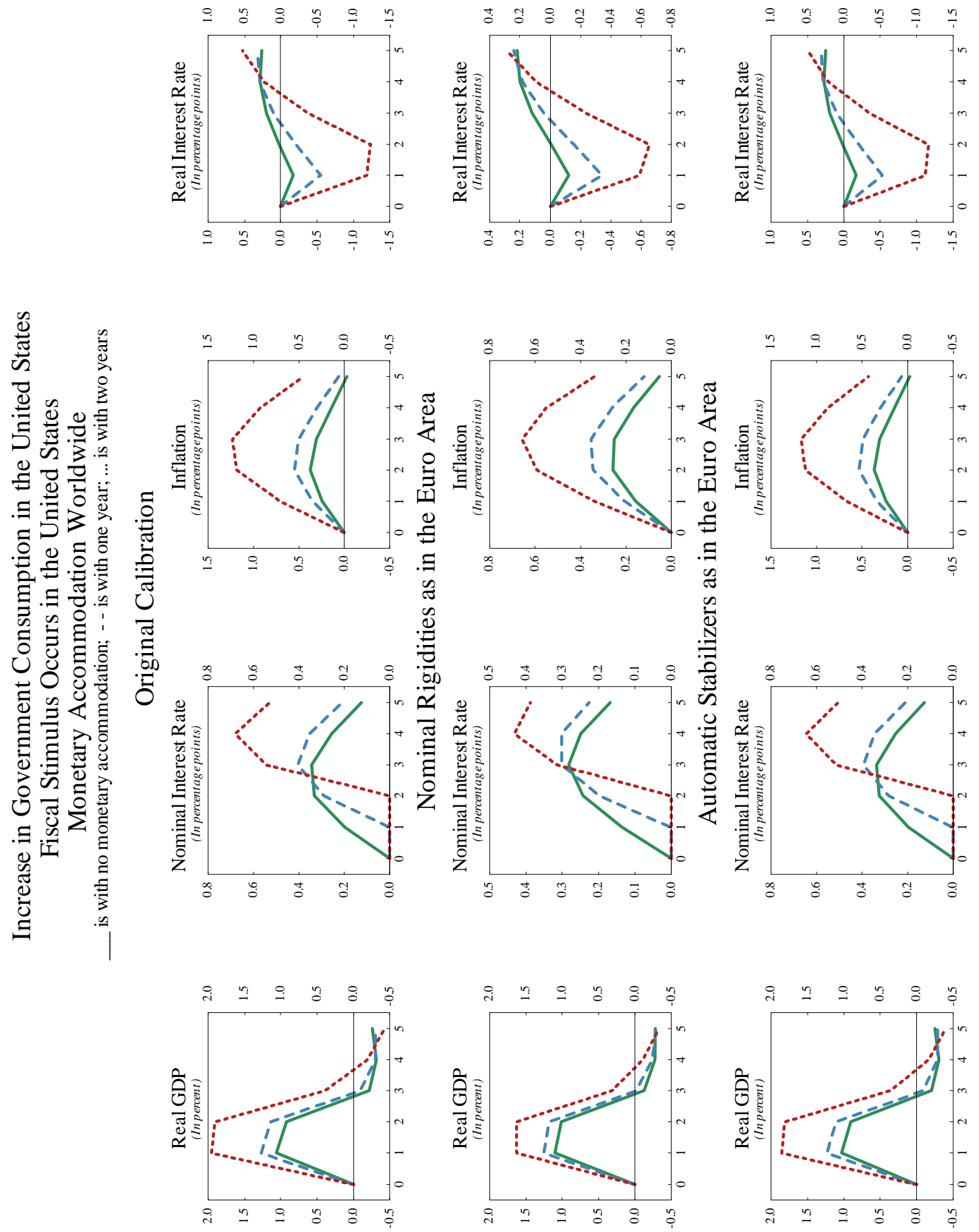
Figure 90. United States: Effect of 1 Year Fiscal Stimulus and Permanent Change in the Fiscal Instrument on Real GDP (Instrument: Government Consumption)

No Monetary Accommodation (In percent)

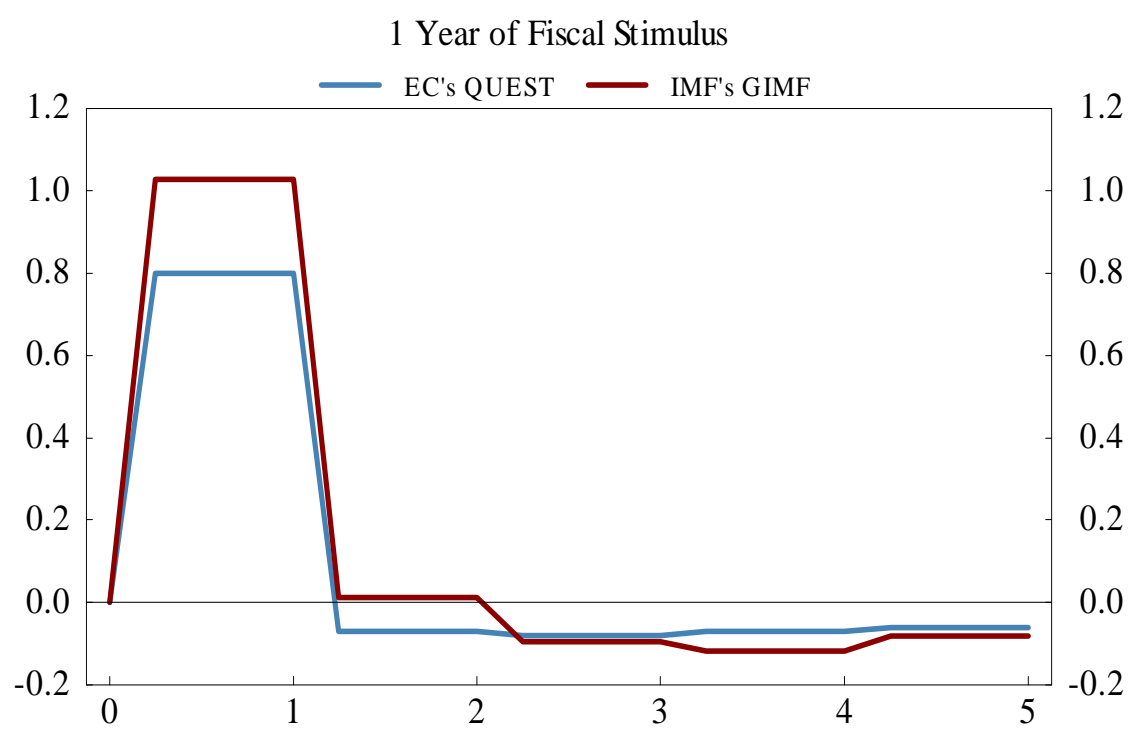

Permanent Change in the Fiscal Instrument

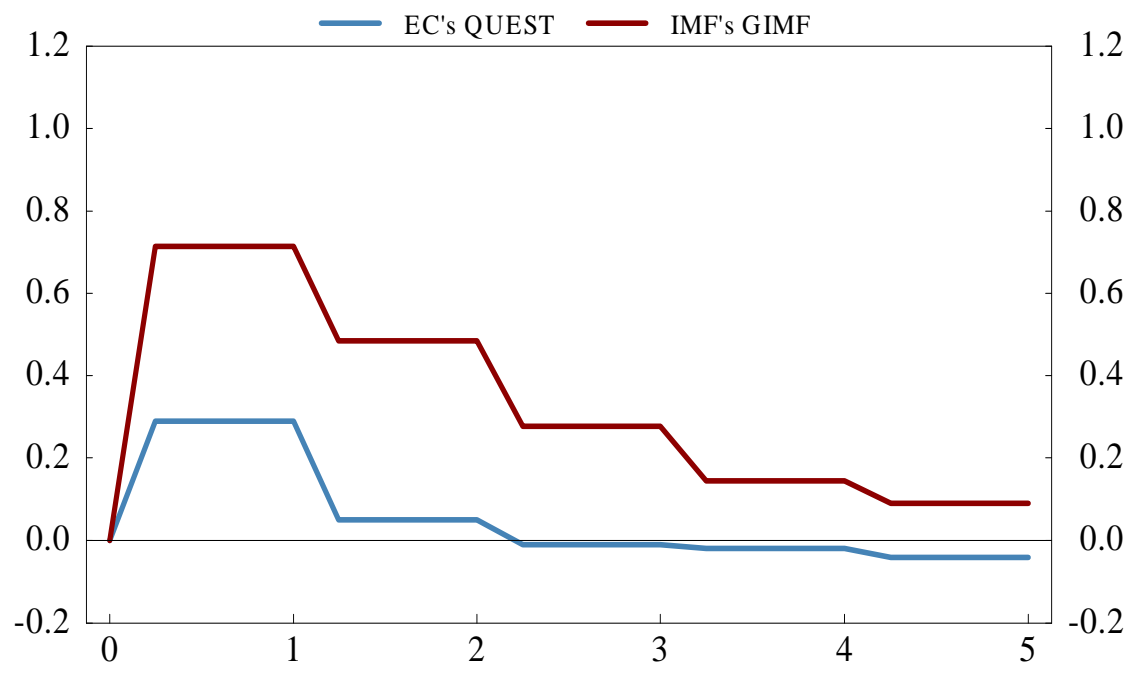


Figure 91. Effect of a Permanent Change in Government Consumption in the IMF's GIMF (Shock versus Control)

\section{United States}

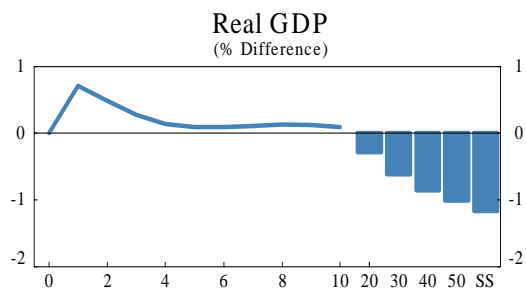

Consumption , Investment -

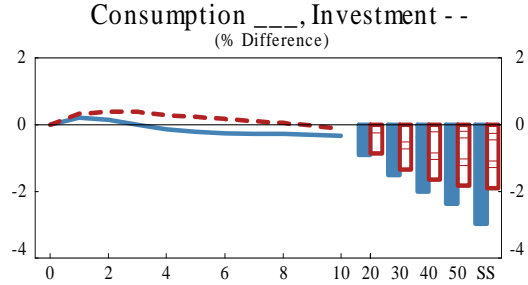

Real Gov't Spending

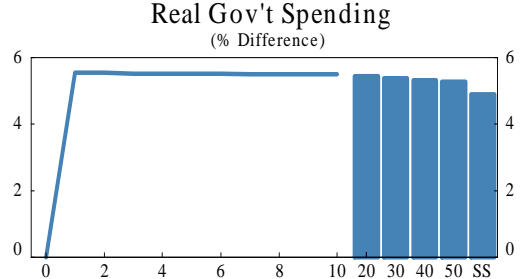

Trade/GDP _-, Current Acc't/GDP - -

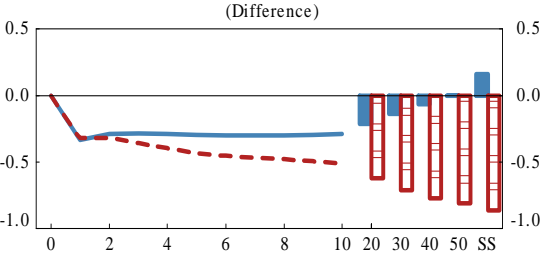

Government Deficit/GDP (Difference)

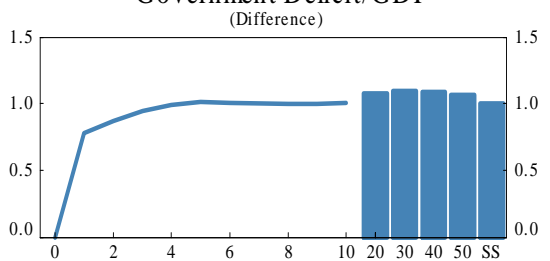

Private Savings/GDP

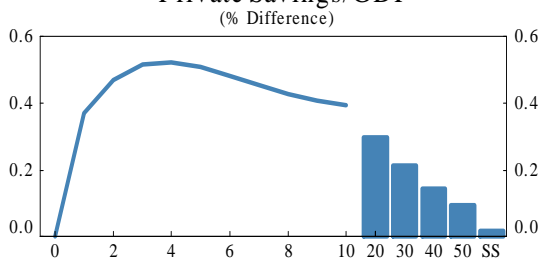

Real Income

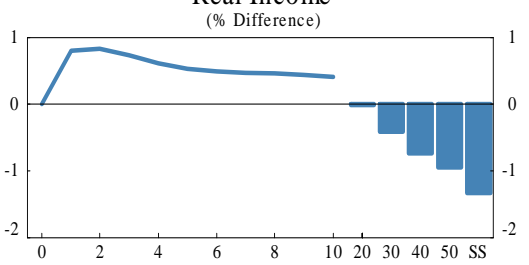

Nominal Policy Rate ___ and CPI Inflation - -
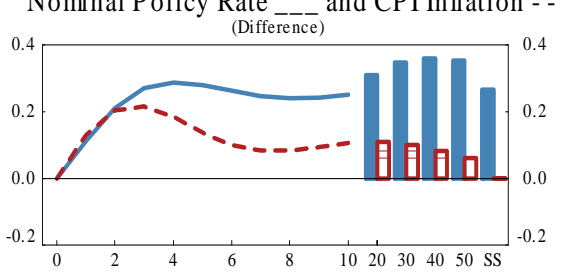

Real Interest Rate

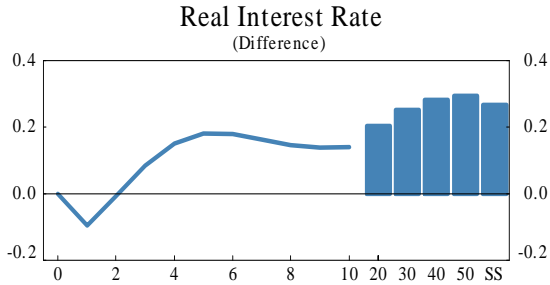

Real Effective Exchange Rate

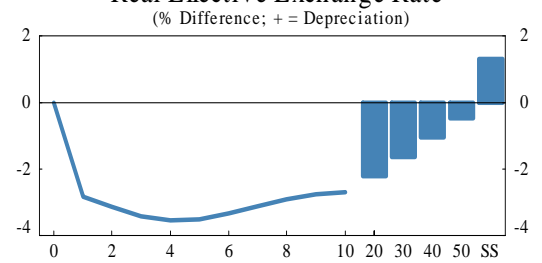

Government Debt/GDP
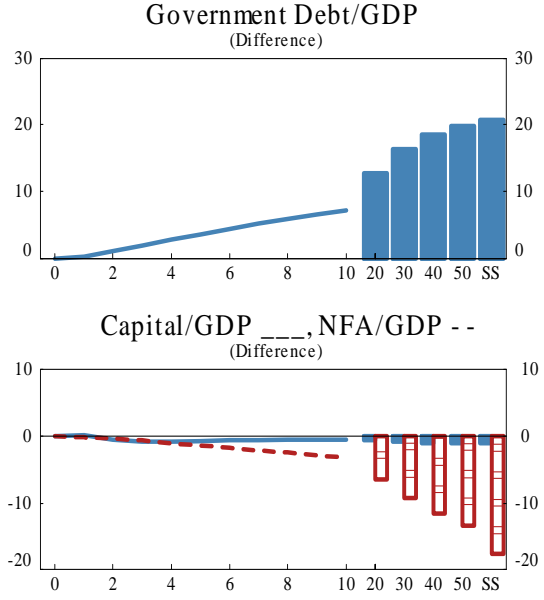
Figure 92. G20 Fiscal Stimulus Packages: Effect on Real GDP

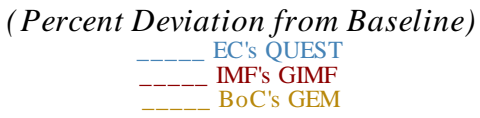

United States 2 Years of Monetary Accommodation

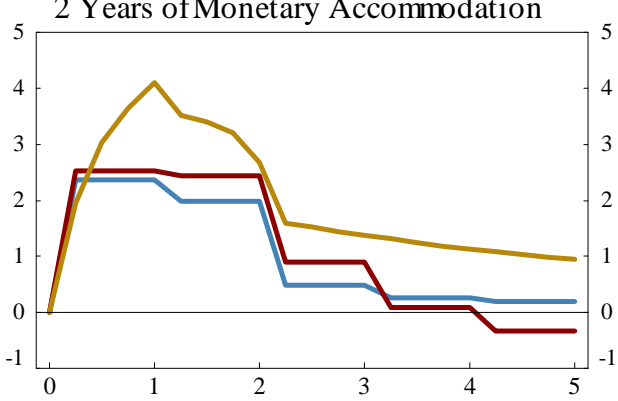

Rest of the World 2 Years of Monetary Accommodation

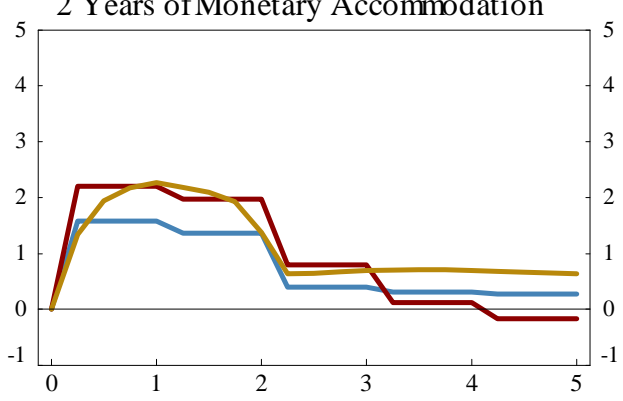

Global 2 Years of Monetary Accommodation

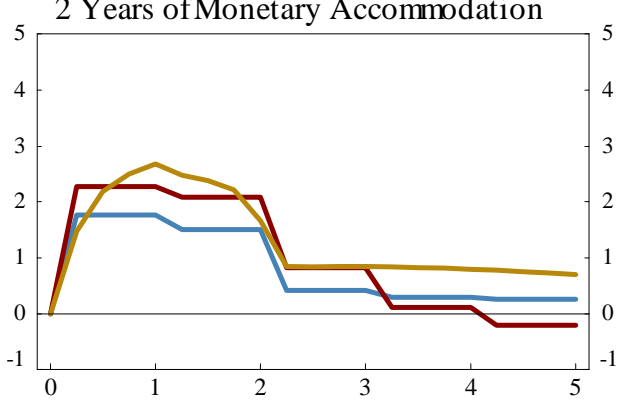

United States

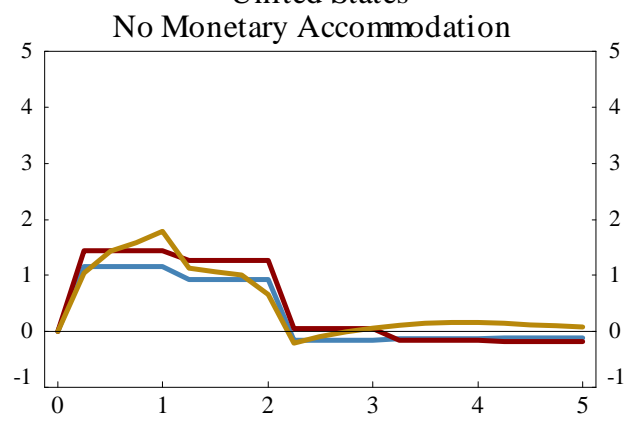

Rest of the World

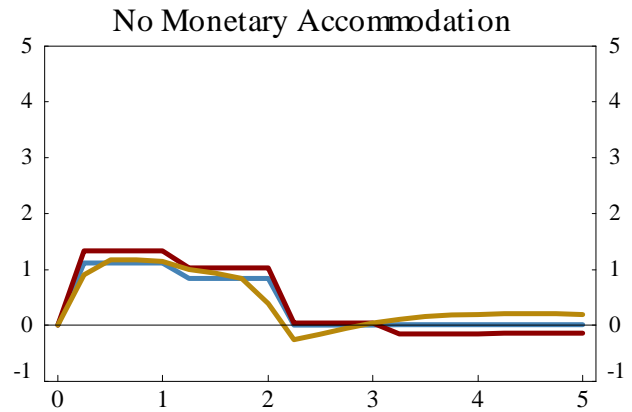

Global No Monetary Accommodation

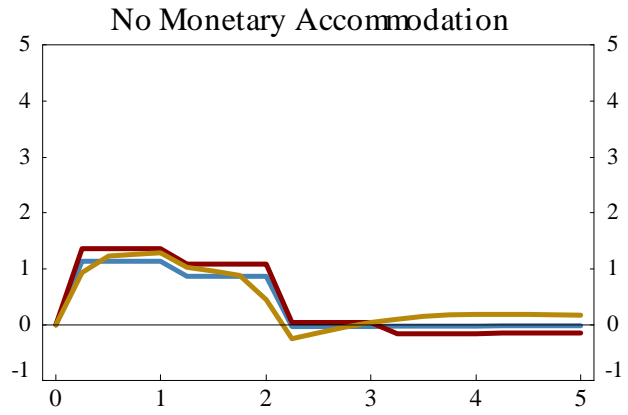


Table 1. Key Model Features

\begin{tabular}{|c|c|c|c|c|c|}
\hline & $\begin{array}{l}\text { \# of } \\
\text { regions }\end{array}$ & $\begin{array}{l}\text { Hand-to- } \\
\text { Mouth \% }\end{array}$ & $\begin{array}{l}\text { Monetary } \\
\text { Policy }\end{array}$ & $\begin{array}{l}\text { Special } \\
\text { Features } *\end{array}$ & References \\
\hline QUEST & 3 & $\begin{array}{l}20 \% \text { HTM } \\
20 \% \text { CC }\end{array}$ & Taylor Rule & $\begin{array}{l}\text { Households: HTM, CC, INF; } \\
\text { productive gov. investment; housing; } \\
\text { endogenous gov. debt risk premia }\end{array}$ & $\begin{array}{l}\text { Ratto, Roeger, and } \\
\text { in 't Veld (2009) } \\
\text { Roeger and in 't Veld (2009) }\end{array}$ \\
\hline GIMF & 5 & $25 \%$ & $\operatorname{IFB} * * *$ & $\begin{array}{l}\text { Households: HTM, FIN; } \\
\text { productive gov. investment; } \\
\text { financial accelerator. }\end{array}$ & $\begin{array}{l}\text { Kumhof and Laxton (2007) } \\
\text { Kumhof and others }(2010) \\
\text { Freedman and others (2010) }\end{array}$ \\
\hline$F R B-U S$ & 1 & $40 \%$ & Taylor Rule & $\begin{array}{l}\text { Households: HTM, INF; } \\
\text { very detailed breakdown; } \\
\text { substantial work on empirics. }\end{array}$ & Brayton and Tinsley (1996) \\
\hline$S I G M A$ & 2 & $50 \%$ & Taylor Rule & Households: HTM, INF. & $\begin{array}{l}\text { Erceg, Guerrieri and Gust } \\
(2005)\end{array}$ \\
\hline$B o C-G E M$ & 6 & $15 \%$ & IFB & $\begin{array}{l}\text { Households: HTM, INF }{ }^{* *} \text {; } \\
\text { productive gov. investment; } \\
\text { separate sectors for oil and non-oil } \\
\text { commodities. }\end{array}$ & $\begin{array}{l}\text { Lalonde and Muir (2007) } \\
\text { Lalonde, de Resende, and } \\
\text { Snudden (2010) }\end{array}$ \\
\hline$N A W M$ & 2 & $25 \%$ & Taylor Rule & $\begin{array}{l}\text { Households: HTM, INF; } \\
\text { HTM can smooth consumption } \\
\text { through cash. }\end{array}$ & $\begin{array}{l}\text { Coenen, McAdam and } \\
\text { Straub (2008) }\end{array}$ \\
\hline $\begin{array}{l}\text { OECD } \\
\text { Fiscal }\end{array}$ & 1 & $25 \%$ & Taylor Rule & $\begin{array}{l}\text { Households: HTM, INF; endogenous } \\
\text { government debt risk premium. }\end{array}$ & $\begin{array}{l}\text { Furceri and Mourougane } \\
(2010)\end{array}$ \\
\hline
\end{tabular}

* Households: HTM = hand to mouth; $\mathrm{CC}=$ credit constrained; FIN = finite lives; $\mathrm{INF}=$ infinitely lived.

** BoC-GEM has a non-Ricardian link between net foreign assets and government debt. $* * *$ IFB $=$ inflation-forecast-based rule. 
Table 2. Effects of a Permanent 10 Percentage Point Increase in the U.S. Government Debt to GDP Ratio

US RoW Global

Financed by a Cut in General Transfers

$\begin{array}{lrrr}\text { Real GDP } & -0.30 & -0.17 & -0.20 \\ \text { Real Exchange Rate } & 0.88 & -0.88 & \ldots \\ \text { Real Interest Rate } & 0.10 & 0.10 & 0.10 \\ \text { Current Account to GDP } & -0.32 & 0.10 & \ldots \\ \text { Investment } & -0.56 & -0.42 & -0.45 \\ \text { Goverment Deficit to GDP } & 0.48 & -0.00 & 0.11 \\ \text { Private Saving to GDP } & 0.12 & 0.04 & 0.06 \\ \text { General Transfers to GDP } & -0.14 & -0.06 & -0.08\end{array}$

Financed by an Increase in Consumption Taxes

Real GDP $\quad-0.38 \quad-0.18$

$\begin{array}{lll}\text { Real Exchange Rate } & 0.79 & -0.79\end{array}$

Real Interest Rate $\quad 0.10 \quad 0.10$

Current Account to GDP $\quad-0.33 \quad 0.10$

Investment $\quad-0.64 \quad-0.45$

Goverment Deficit to GDP $\quad 0.48$

$\begin{array}{lrrr}\text { Private Saving to GDP } & 0.11 & 0.05 & 0.06\end{array}$

$\begin{array}{llll}\text { Consumption Tax Rate } & 0.35 & 0.00 & 0.08\end{array}$

Financed by an Increase in Corporate Income Taxes

$\begin{array}{lrrc}\text { Real GDP } & -0.71 & -0.23 & -0.33 \\ \text { Real Exchange Rate } & -0.01 & 0.01 & \ldots \\ \text { Real Interest Rate } & 0.09 & 0.09 & 0.09 \\ \text { Current Account to GDP } & -0.30 & 0.09 & \ldots \\ \text { Investment } & -1.92 & -0.47 & -0.79 \\ \text { Goverment Deficit to GDP } & 0.48 & -0.00 & 0.11 \\ \text { Private Saving to GDP } & -0.03 & 0.04 & 0.03 \\ \text { Corporate Income Tax Rate } & 1.35 & 0.00 & 0.30\end{array}$

Financed by an Increase in Labor Income Taxes

$\begin{array}{lrrc}\text { Real GDP } & -0.48 & -0.21 & -0.27 \\ \text { Real Exchange Rate } & 0.74 & -0.75 & \ldots \\ \text { Real Interest Rate } & 0.11 & 0.11 & 0.11 \\ \text { Current Account to GDP } & -0.36 & 0.11 & \ldots \\ \text { Investment } & -0.77 & -0.50 & -0.56 \\ \text { Goverment Deficit to GDP } & 0.48 & 0.00 & 0.11 \\ \text { Private Saving to GDP } & 0.08 & 0.05 & 0.05 \\ \text { Labor Income Tax Rate } & 0.44 & 0.00 & 0.10\end{array}$


Table 3. G20 Fiscal Stimulus Packages

2009

$\begin{array}{lccccccccc}\text { \% of domestic GDPP } & \text { Gov. } & \text { Gov. } & \begin{array}{c}\text { Social } \\ \text { Safety } \\ \text { Consump. }\end{array} & \begin{array}{c}\text { Gen. } \\ \text { Invest. }\end{array} & \begin{array}{l}\text { Net } \\ \text { Trans. }\end{array} & \begin{array}{l}\text { Labor } \\ \text { Income } \\ \text { Tax Cut }\end{array} & \begin{array}{l}\text { Consump. } \\ \text { Tax }\end{array} & \begin{array}{l}\text { Corp. } \\ \text { Income }\end{array} \\ \text { United States } & 0.44 & 0.23 & 0.55 & 0.09 & 0.26 & 0.00 & 0.41 & 1.98 \\ \text { Euro Area } & 0.03 & 0.27 & 0.14 & 0.10 & 0.19 & 0.07 & 0.03 & 0.83 \\ \text { Japan } & 0.00 & 0.32 & 0.95 & 1.06 & 0.04 & 0.00 & 0.05 & 2.42 \\ \text { Emerging Asia } & 0.22 & 1.36 & 0.24 & 0.08 & 0.06 & 0.13 & 0.07 & 2.16 \\ \text { Other Countries } & 0.14 & 0.14 & 0.26 & 0.12 & 0.04 & 0.02 & 0.13 & 0.85\end{array}$

2010

\begin{tabular}{|c|c|c|c|c|c|c|c|c|}
\hline$\%$ of domestic GDP & Gov. & Gov. & $\begin{array}{l}\text { Social } \\
\text { Safety }\end{array}$ & Gen. & $\begin{array}{l}\text { Labor } \\
\text { Income }\end{array}$ & $\begin{array}{l}\text { Consump. } \\
\text { Tax }\end{array}$ & $\begin{array}{l}\text { Corp. } \\
\text { Income }\end{array}$ & TOTAI \\
\hline United States & $\begin{array}{c}\text { Consump. } \\
0.47\end{array}$ & $\begin{array}{c}\text { Invest. } \\
0.33\end{array}$ & $\begin{array}{c}\text { Net } \\
0.10\end{array}$ & $\begin{array}{c}\text { Irans. } \\
0.10\end{array}$ & $\begin{array}{c}1 \text { ax } c \text { ut } \\
0.55\end{array}$ & 0.00 & $\begin{array}{c}1 \text { ax } c \text { ut } \\
0.22\end{array}$ & $\begin{array}{c}\text { IU1AL } \\
1.77\end{array}$ \\
\hline Euro Area & 0.02 & 0.13 & 0.07 & 0.02 & 0.34 & -0.04 & 0.19 & 0.73 \\
\hline Japan & 0.00 & 0.58 & 0.20 & 0.94 & 0.03 & 0.00 & 0.04 & 1.79 \\
\hline Emerging Asia & 0.22 & 1.38 & 0.07 & 0.00 & 0.05 & 0.15 & 0.14 & 2.01 \\
\hline Other Countries & 0.09 & 0.04 & 0.08 & 0.02 & 0.07 & 0.00 & 0.13 & 0.43 \\
\hline
\end{tabular}

